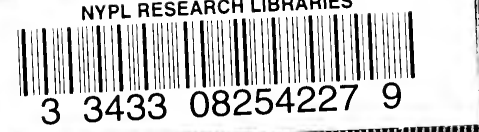

(in) (in)
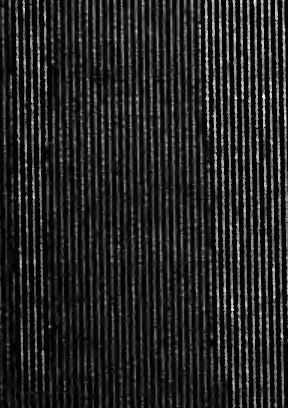


\section{Digitized by the Internet Archive in 2007 with funding from Microsoft Corporation}




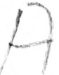

4 






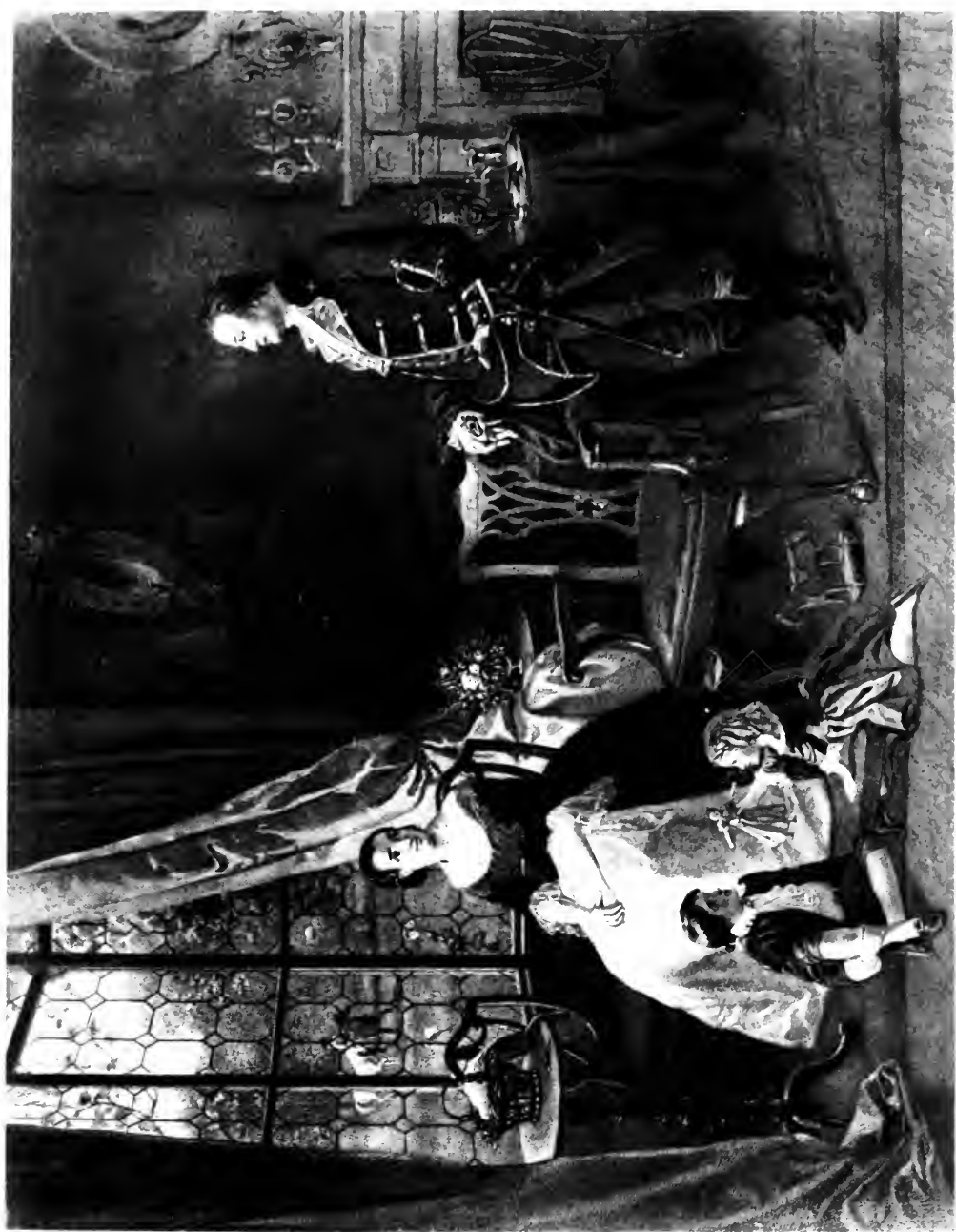




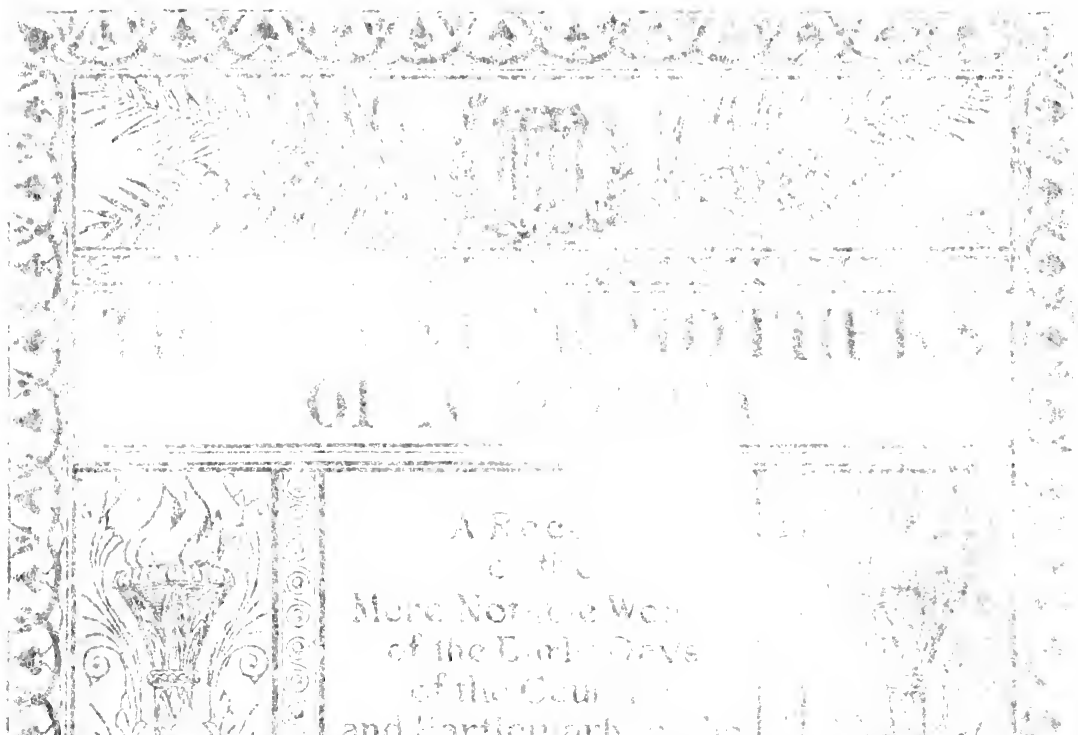

Whishington's First Intervipw with Nartha Custis

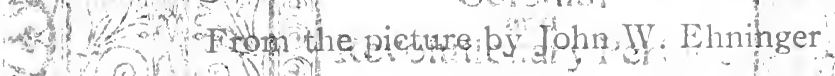

vor dyon Whote

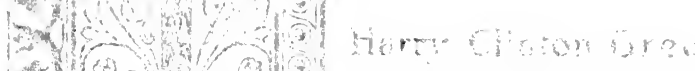

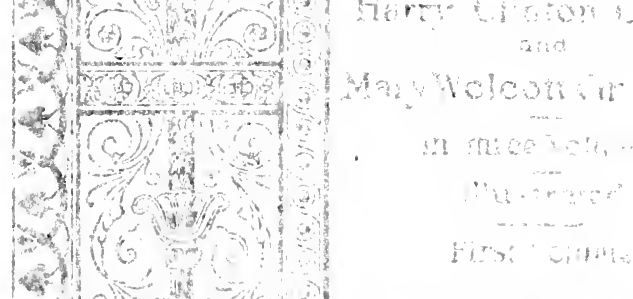

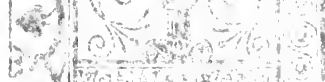

(n)

W

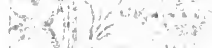

$x_{1}$

W

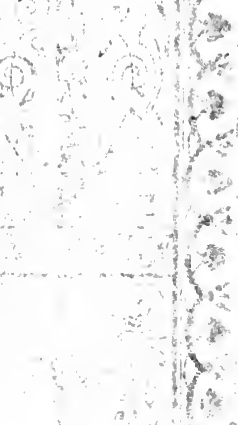




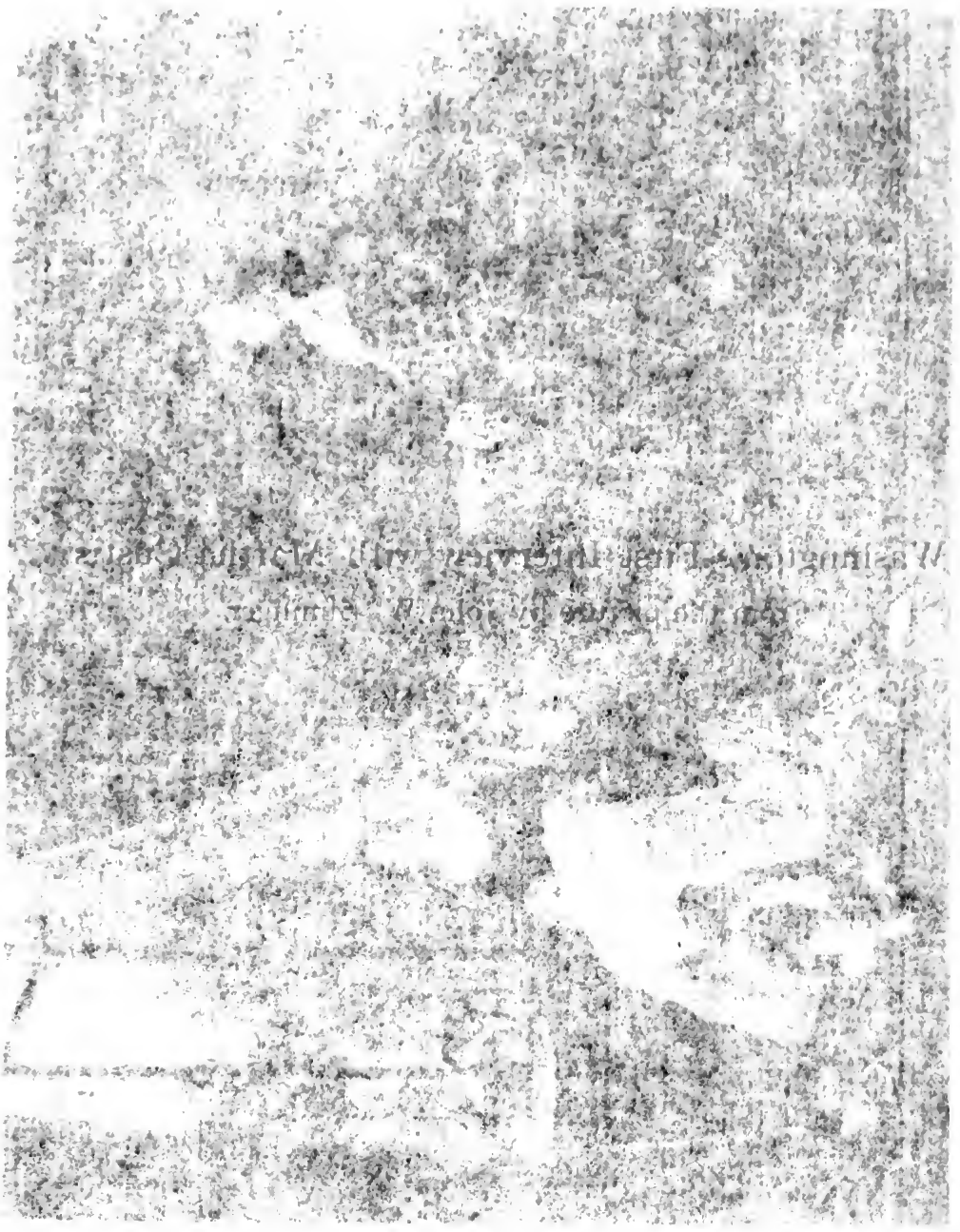




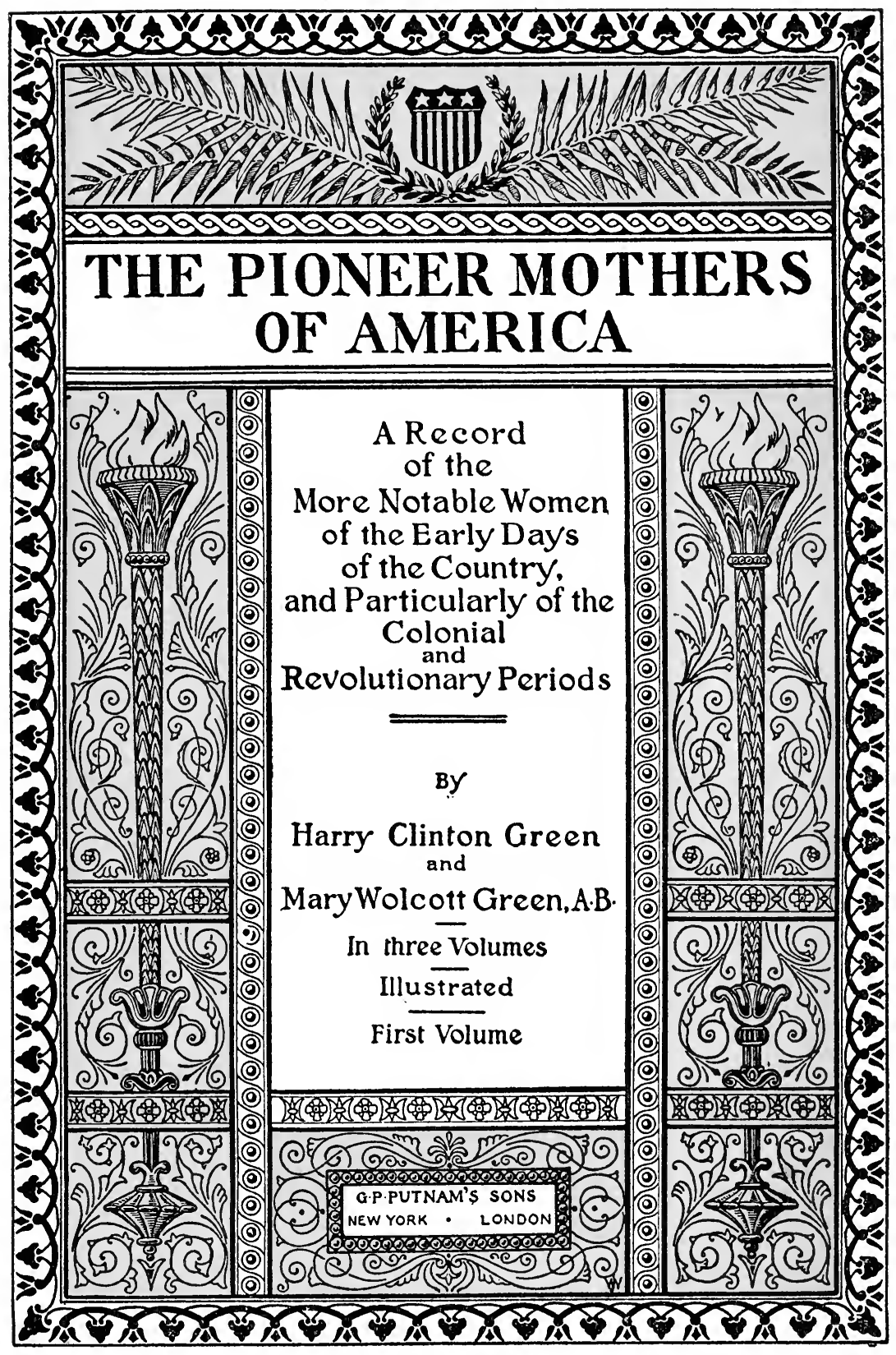




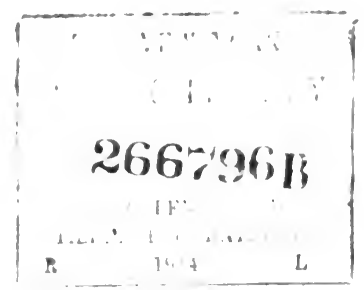

Copyright, I9I2

BY

G. P. PUTNANS SONS

The tkntckerbocker Dress, Hew pork 


\section{Preface}

H ISTORY has in the main been written by men and about men. This was generally in accord with the spirit of the times when men were dominant in most worldly affairs. In the following pages we have aimed to do tardy justice to the memory of the women who have so splendidly done their part in helping onward the progressing destinies of the human race-not alone as mothers, bearing sturdy sons and daughters, but, by precept and example, training them to independent thinking and to brave, honest, and patriotic living. Of the individual lives of a great majority of these women, no one may know; the details have been lost in the lapse of years. But here and there tradition or record has brought into bolder relief some noted woman who, by the accident of birth or station, dramatic incident or native force of character, has been helpful in the making of history. These volumes have been prepared not only to periii 
petuate the memory of such women, but to accentuate the lessons they have left behind in the making of good citizens and broader and better men and women.

But little systematic arrangement has been attempted in the grouping of the following sketches; there has been no idea of balancing New England or New York against Virginia or the Carolinas; no setting up of Puritan stock against Cavalier, or Protestant against Catholic. We have simply taken the characters as we chanced to find them, using such as seemed best illustrative of the period in which they lived or of the principles for which they stood. It is not possible to claim absolute authenticity of detail in the less important facts. In not a few cases, such detailed information has been lost, or if found would in no wise enhance either the interest or the value of the personality.

In the preparation of our work, we have not only searched general and State histories, county histories where they could be found, biographies, and family genealogies, but have corresponded directly with descendants of a majority of the notable women whose lives are here recorded. In this we have been vastly aided by the lineage 


\section{Dreface}

books of the Daughters of the American Revolution, the members of which are, as a requisite for admission to the Society, required to trace their ancestry back to Revolutionary stock. We have also profited in another way from that great organisation. It is the general custom of the Daughters to name their local chapters in honour of some patriotic, historical character. Often it is a woman who is chosen as such "patron saint," and almost as often, one who is the ancestress of one or more members of the chapter, and the chapter has thus become possessed of direct or traditional information not attainable elsewhere.

In the chapters devoted to the wives of the generals of the Revolutionary War and the wives of the signers of the Declaration of Independence, great difficulty was experienced in the collection of authentic data. Of the soldiers and statesmen of that period, shelvesful of books have been written, but their wives, if mentioned at all, are dismissed with a few lines. Yet almost without exception they were brave, patriotic women, who loyally supported their husbands, sent their sons to fight in the ranks, and uncomplainingly suffered for the cause actual physical 
hardships as well as mental anguish. Surely the courage and self-sacrifice, the steadfast faith of these women were worth commemorating. Yet in no book or set of books can there be found even desultory sketches of many of the noble women whose silent influence was to be felt so strongly in the founding of the new Republic. This is not said in boastfulness over having recalled something of the lives of these devoted women, but rather as an apology for the inadequacy of the work we have accomplished, as compared with what might have been done if the task had been taken up while yet the principals or their immediate descendants were alive and before the records had been lost or destroyed.

In the preparation of this work we have received aid from many sources. We wish to express our acknowledgment of the uniform and helpful courtesy extended to us by the officials and attendants of the New York Public Library, and its branches at St. George and Port Richmond, S. I., and especially to those in charge of the historical and genealogical departments. Our acknowledgments are also due to the Library of Columbia University; the Public Library of Jersey City; the Historical Societies of 


\section{preface}

New York, Philadelphia, New Jersey, Maryland, Massachusetts, and Connecticut; the Congressional Library at Washington; the late Mrs. Elroy M. Avery, editor, American Monthly Magazine; Mrs. Amos G. Draper, genealogist, of Washington, D. C.; Dr. Grace Raymond Hebard, librarian, Wyoming University; Miss Jennie Loomis, Windsor, Ct.; Mrs. Francis Roberts, Honorary State Regent, D.A. R., of New York; Mrs. Joseph Wood, State Regent, D.A.R., New York; Mary Florence Taney, Kentucky; Mrs. Alice Crary Sutcliffe, New York; Mary Trumbull Morse, New York; Hon. Albert Mathewson, Connecticut; John Calvert, Philadelphia; Mrs. Ellis Logan, National Corresponding Secretary, Children of the American Revolution; Mrs. Kathryn Thorp, State Regent, D. A. R., Florida; Mrs. Sara T. Kinney, State Regent, D.A.R., Connecticut; Mrs. Murray E. Foristell, State Registrar, D.A.R., of Missouri; Florence M. Espy, Library Department, Notre Dame University, Ind.; Francis Lynde Sullivan, Esq., Boston; Frank Allaben, editor, Journal of American History; Mrs. R. J. Herndon, South Carolina; Mrs. Benjamin B. Smith, Pennsylvania; Mrs. M. H. Bennett, Minnesota; Mrs. 
Louise Barnum Robbins, Michigan; Mrs. A. L. Simpson, Maine; Mrs. A. S. Merrill, Massachusetts; Mrs. C. A. J. Queck-Berner, Corresponding Secretary, New York State, D.A.R.; Mrs. Dell P. Glazier, Iowa; Col. Thomas Sumter, South Carolina; Mrs. Mary Van Ostrand Vandegrift, Washington, D.C.; Mrs. W. C. Robinson, Vice State Regent, D.A.R., Maine; Mrs. Helen A. Engle, Washington, D.C.; Grace M. Pierce, ex-Registrar-General, D.A.R., Vice-President, C.A.R.; Mrs. Mary C. Wysong, Washington, D.C.; Mrs. Charlotte Pendleton, Maine; Mrs. Jason McIlwain, Michigan; Mrs. C. R. Backus, Washington, D.C.; Mrs. George A. Lawrence, Illinois; Carrie Choice Simms, Tennessee; Mrs. A. Worthley, Kansas; Mrs. Helen C. Sergeant, Massachusetts; Mrs. Mary H. S. Johnson, Iowa; Mrs. Myra C. Morehouse, Massachusetts; Mrs. Z. S. Wittemore, Massachusetts; Augusta Lamb, Massachusetts; Helen Wheelock Taft, Massachusetts; Mary Pettus Thomas, Baylor College, Texas; Gertrude Blauvelt, Washington, D.C.; Mrs Gertrude H. Lippett, Connecticut; Mrs. Edward O. Lukens, New Jersey; Lillie W. McCandless, Pennsylvania; Mrs. E. G. A. White, Massachu- 


\section{Preface}

setts; Mrs. Charles S. Proctor, Massachusetts; Mrs. Susannah G. Webster, Illinois; Mrs. Hattie P. Allen, Maine; Mrs. Winona Sherwood, Michigan; Mrs. Florence Small, Maine; Mrs. Sarah P. Webster, New Hampshire; Mrs. Helen E. M. Heald, Massachusetts; Mrs. Mattie Lee Staton, Georgia; Mrs. Margaret H. Wells, Michigan; Elizabeth T. Howe, Missouri; Mrs. N. B. McCall, Georgia; Mrs. Charlotte Brodhead Burke, New Jersey; Mrs. R. R. Bittman, Kansas; Mrs. James P. Moore, North Carolina; Mrs. Mary Shackleford, Kentucky; Mrs. John E. Lydick, Texas; Mrs. Bessie Plumer Norris, New Hampshire; Mrs. J. T. Doneghy, Missouri; Mrs. Lavinia C. Reilly, Mississippi; Mrs. Helen L. Steele, New Hampshire; Mrs. Mary B. Cilley, New Hampshire; Mrs. Ella S. Campbell, Iowa; Mrs. O. S. Paige, Massachusetts; Mrs. Florence Sarah Stoddard, Michigan; Mrs. Sarah L. B. Comins, New York; Mrs. Charles H. Hatton, Kansas; Mrs. Agnes M. Walton, Maryland; Althea M. Ringo, Missouri; Mrs. Abbie D. Grimes, New Hampshire; Mrs. E. B. Townsend, Washington, D. C.; Mrs. Pearl Green Clement, Texas; Mrs. E. N. Dingley, Michigan; Mrs. Edith M. Goodrich, New Hampshire; Mabelle 
Smith, Mississippi; Mrs. Ella T. Wente, Michigan; Mrs. F. O. Wellington, Massachusetts; Mrs. N. Burleigh, New Hampshire; Mr. C. F. Haverly, Pennsylvania; Mrs. George H. Shedd, New Hampshire; Mrs. Frank L. Erwin, Michigan; Mrs. Helen Turner, Illinois; Mrs. Mary Cole Smith, Maine; Mrs. D. J. Evans, Ohio; Mrs. H. M. Sawyer, Michigan; Mrs. Elizabeth Merrill, Maine; Mrs. Mary Howland Bellows, New Hampshire; Mrs. Mary Hunter Gibony Hauck, Missouri; Jeanette Burlingham, Wisconsin; Mrs. Ida McF. Potter, Nebraska; Mrs. James M. Arnold, Kansas; Mrs. M. T. Coverly, Vermont; Mrs. Fannie E. Means, Illinois; Mrs. C. E. Andrews, Maine; Mrs. Mary Crooker Lloyd, Illinois; Mrs. C. S. Hall, Kansas; Mrs. J. P. Chew, Ohio; Mrs. Margaret H. Ells, Michigan; Mrs. Caroline R. Fairbank, Indiana; Mrs. Carroll E. Miller, Michigan; Mrs. M. E. Davis, Washington, D.C.; Mrs. Ella M. Ballard, Kansas; Mrs. J. M. Kirkpatrick, Kansas; Mrs. William Libby, State Regent, D.A.R., New Jersey; Claudine Rhett, South Carolina; Hon. Artemas Ward, New York; Mrs. Caroline V. R. Wright, New York; Mrs. V. V. Hart, West Virginia; Mrs. Huling P. Robertson, ex-Vice Regent, D.A.R., Texas; Mrs. M. Macdougal, New Jersey; Mrs. C. New- 
comb Stevens, Texas; Mrs. J. N. Baughman, Indiana; Mrs. Alexina W. Davis, Kansas; Mrs. R. A. Ehmann, New York; Josephine Garretson, Iowa; Mr. J. Hervey Stout, New Jersey; Mrs. Hugh Montgomery, Kentucky; Mrs. Florence King Draper, State Genealogist, D. A. R., Alabama; Mrs. Arthur Kyle Davis, Virginia; Mrs. Marietta M. Wonson, Massachusetts; Mrs. Eliza Merrill Hadlock, Pennsylvania; Mrs. Grace Barton Blakeslee, Kansas; Mrs. Alice Johnson Bugbee, Connecticut; Mrs. Lillian Franklin Gregory, Kentucky; Mrs. Frances Shippen Hollister, Pennsylvania; Marian D. Davis, Mississippi; Ethelwyn Bassett Hall, Washington, D.C.; Mrs. C. E. Scott-Waring, New York; Mrs. Elsie Chapline Cross, California; Mrs. George Russell, Massachusetts; Mrs. E. D. Wheeler, Michigan; Mrs. Emma F.Allen, Massachusetts; Mrs. Jennie D. Andrews, Missouri; Mr. Jeffrey W. Taylor, Pennsylvania; Anabelle Burford, Texas; Mrs. Frank B. Johnson, Massachusetts; Mrs. W. H. Burns, Minnesota; Mrs. John T. Moody, Georgia; Mrs. Orianna Simons, Indiana; Mrs. George F. Arnold, Maine; Mrs. Kate Heal Jarvis, New York.

West New BRighton,

Staten Island, N. Y., I9I2. 



\section{Contents}

\section{INTRODUCTORY}

\section{AMERICAN WOMANHOOD IN THE MAKING}

English Cavaliers who Came to Virginia in I607, Dutch Traders to New York in I6I3, and Puritans to New England in I620, the Vanguard of a New World Civilisation-Followed by English Catholics to Maryland, English Quakers, Scotch Presbyterians, and Germans from the Palatinate to New Jersey and Pennsylvania, and French Huguenots to the Carolinas-A Medley of Religious Faiths, Customs, Conditions, and Nationalities, with the English ever the Dominant Spirit-And always Was Love, of Husband or Family, the Motive that Led Woman Voluntarily to Seek Pioneer Life on the New Continent . . . . . . . . 3-I7

\section{CHAPTER I \\ THE WOMEN OF PIONEER DAYS}

Through the Hardships and Dangers, the Sorrows and Joys of Pioneer Life Woman Came to Walk Shoulder to Shoulder with Man, Sharing his Labours in Forest and Field, as well as his Cares and Compensations at Home-Necessity Compelled her to Become Man's Real Helpmeet, and their Association and Isolation Led to their Mental Development along Similar Lines-Together they Developed the Same Sturdy, Alert Self-Reliance, the Same Independence and Courage-Together they Faced the Mal-Administration of Colonial Governors in whose Appointment they Had No Part, and the Constant Encroachment of the Crown's Representatives upon their Inherent Rights and Privileges-The Natural Evolution of the Brave, Patriotic, and High-Spirited Dames and Daughters of Colonial Days . . . 2 21-66 


\section{CHAPTER II}

\section{POCAHONTAS-VIRGINIA}

Daughter of Powhatan, Powerful Indian Chief of Eastern Virginia, she Was Fast Friend of First English Settlers who Went there in 1607 -She is Said to have Saved the Life of Captain John Smith, Condemned to Death by her Father, and Shown Many Evidences of a Humane and Gentle Nature -The First Woman of her Race Known to Embrace Christianity-She was Married to John Rolfe, a Young Planter, who Carried her to England, where she was well Received by Royalty and Nobilty-She Died at the Age of Twentytwo, Generally Honoured and Respected, Leaving One Son, through whom her Blood is Mingled with Some of the Best of the Old Dominion-Other of the First Families 69-110

\section{CHAPTER III}

\section{PRISCILLA MULLINS OF PLYMOUTH}

The Maiden of the Mayflower, Made Famous by the Storied Romance of her Wooing by John Alden, who has Come to Stand Typical of the Puritan Young Womanhood of New England-Susanna White, Mary Brewster, Elizabeth Hopkins, and Helen Billington, the Four Pilgrim Mothers who Lived through the Awful "First Winter"-Mary Chilton, the First Woman whose Foot Touched Plymouth RockAlice Southworth Bradford and Other Mothers of the First Families of Massachusetts-Story of the Coming of the Pilgrims and the Founding of Plymouth Colony . I I3-I52

\section{CHAPTER IV}

\section{ANNETJE JANS, NEW YORK}

A Splendid Type of the Sturdy, Thrifty, Capable Dutch Women who Came First to New Amsterdam-Her Husband, Roelof Jans, Was Farm Superintendent for Patroon Killiaen Van Rensselaer, I630 to I635-Removed his Wife and Five Children from Fort Orange to Manhattan Island, where he was Given One of the Farms Feserved by the West India Com- 


\section{Contents}

PAGES

pany, upon which he Died soon afterward-The Widow Married Dominie Bogardus in 1638 and Bore him Five Children before he was Lost at Sea in I646-Annetje Jans's Farm a Subject of Litigation for Two Centuries-The Story of her Descendants, with those of Cornelia Lubbetse, Annetje Lockermans, Margaret Hardenbroeck, Katrina Van de Brough, and Arientje Jans, Is Largely the History of New York for a Century I55- 198

\section{CHAPTER V}

\section{ANN HUTCHINSON}

America's First Club Woman-She was Excommunicated by her Church, and Exiled by Massachusetts Bay Colony for Heresy in 1638 -Removed with her Family to Rhode Island where her Husband Died a Magistrate-She and her Youngest Children Murdered by Indians at Pelham Manor in 1644-A Descendant, Thomas Hutchinson, Was the Last Royal Governor of Massachusetts-Lady Deborah Moody, a Religious Exile who Came to Long Island-The Witchcraft Craze of Salem

\section{CHAPTER VI}

\section{EUNICE WILLIAMS}

One of the Victims of the Sack of Deerfield by the French and Indians in 1704 -She with her Husband, Pastor of the Flock, and One Hundred and Ten Other Captives were Dragged from their Homes at Midnight in Midwinter and Started on a March of More than Three Hundred Miles into CanadaMrs. Williams, Hannah Chapin, Mary Brooks, and Several Other Women Perished from the Tomahawk or ExposureRev. John Williams Tells the Story of their Tragic Parting -Hannah Chapin's Sacrifice-Little Eunice Turned Indian,

\section{CHAPTER VII}

SOME NOTEWORTHY WOMEN OF COLONIAL TIMES

Margaret Winthrop, a Puritan Mother of the Old Bay Colony- 
Margaret Brent, a Maryland Portia, the First Woman in America to Demand the Right to Vote-Iady Mary LaTour, a Huguenot Heroine of Acadia, whose Defence of Fort LaTour Is still the Theme of Song and Story-Martha Pitkin, an English Maid who Became the Mother of a Long Line of Noted Colonial Descendants-Ruth Wyllys, the Patriotic Young Matron who Helped Save Connecticut's Charter by Hiding it in the Oak-Letitia Penn, a Quaker Maid, whose Father Founded a Great City-Hannah Dustin, a Prisoner of the Sack of Haverhill, and her Awful Revenge-Betty Martin, a Colonial Belle from the Shores of Chesapeake, who Lived a Century

\section{CHAPTER VIII}

\section{HOME-MAKING IN THE WILDERNESS}

Its Perils and Pleasures, Hardships and Compensations-Sarah Wells, the Maid of Waywayanda, who Went Alone into the Wilds of Eastern New York to Take up a Land GrantCatheryna Rombout Brett, and the Historic Manor she Founded at Fishkill on the Hudson-Mary Draper Ingles, the "First White Bride West of the Alleghenies"; Carried away by the Indians, she Escaped, and Travelled Seven Hundred Miles through the Wilderness to her Home in Virginia-Jemima Howe's Captivity, a Tale of Border Warfare in Northern New Hampshire-Sarah Knight, a Boston Woman who Visited New York in I 704, and her Impressions - Mary Ball Washington, the Mother of the Great Commander 


\section{Illustrations}

PAGE

WAshington's First Interview with Martha Custis

Frontispiece.

From the Picture by John W. Ehninger

The Half-Faced Camp or Pole Shelter - 33 Redrawn from an Old Print

The Type of Log-Cabin Built by Early Set-

TLERS . . . . . . . . .

Redrawn from an Old Print

Household Utensils Used by the Settlers .

Drawn from Old Prints

Spinning Flax.

Redrawn from an Old Print

LANDing at Jamestown, 1607 • • • • 75

From an Old Print

The Tower of the Old Church, at James-

TOWN, VA.

Marriage of Pocahontas $\quad$ • $\quad$ • $\quad$ o 107

From an Old Engraving

Armour Worn by the Pilgrims in 1620 • - I I5

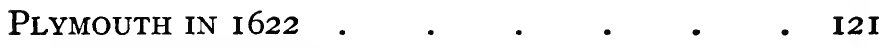

Copyright, I89r, by A. S. Burbank

xvii 


\section{xviii}

\section{IIlustrations}

The "Mayflower" in Plymouth Harbour

From the Painting by W. F. Halsall, in Pilgrim Hall

WATChing the Departure OF The "MAYFlower"

From the Picture by Geo. H. Boughton

MAP OF THE JANS OR Bogardus FARM WITH Position of the Streets Indicated . • I6I

The River and Dock Front, about I642 • 167

View of Lower MARket, I746 • • • • $\quad$ I8I

Broad Street, New York, IN I642 • • I 189

A View on Hutchinson's Creek, Eastchester, NEW YORK . . . . . . . . From a Sketch Made in 1870

The Trial of Martha Corey . . . 229

From the Drawing by John W. Ehninger

From the Illustrated Edition of Longfellow's Works

Reproduced by Courtesy of Messrs. Houghton, Mifflin \& Co.

Door of The “Ensign Sheldon House," with its Hatchet-Hewn Face” . . . . 243

Relic of the Sack of Deerfield, February, 1703/4

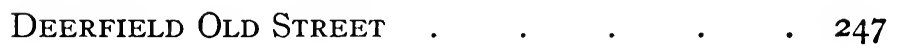

Parson Williams House in Deerfield, Mass. 253

The Old Williams Church and Parsonage $\quad$. 263

Eunice Williams's Grave • • • • $\quad 273$ 


\section{Nllustrations}

xix

PAGE

The Mouth of the Gaspereau River and Grand Pré $\quad$. $\quad . \quad$. . . . $3 \mathrm{I} 3$

Redrawn from an Old Print by William J. Wilson

The Wyllys Mansion and the Charter OAK 349

(From a Drawing in the Possession of Miss Ellen M.

Stuart.) Reproduced from Patron Saints of Conn.

Chapters of the D. A. R.

Pack-Horses And a Conestoga Waggon . • $36 \mathrm{I}$

Redrawn from Old Cuts

The Letitia House

Given by William Penn to his Daughter 369

Now in West Fairmount Park.

The Hannah Dustin Monument, Haverhill 377

The Hannah Dustin Memorial at HaverHILl, MASS. $\quad$. $\quad$. $\quad$. $\quad$. 385 From a Photograph.

The Stone House Built by William Bull

IN I722 1 . $\quad . \quad$. $\quad . \quad$. 405

From a Photograph

Mme. Brett's Home, Fishkill, N. Y. • $4 \mathrm{I} 5$

From a Painting by Rev. Robt. Fulton Crary, D.D.

Mary Ball Washington .

From the Picture Painted by Middleton and Restored by Edward Bird, R.A.

Mount Vernon • • • • • • 465

From a Photograph 

"WHEN I read history and am impressed with any great deed, I feel as if I should like to see the woman who is concealed behind it as its secret incentive."-Heinrich Heine. 



\section{Pioneer Mothers of America}

\section{Introductory}

\section{American Wuomanbood in tbe Saking}

English Cavaliers who came to Virginia in 1607, Dutch Traders to New York in $161_{3}$, and Puritans to New England in 1620, the vanguard of a New World civilisation-Followed by English Catholics to Maryland, English Quakers, Scotch Presbyterians, and Germans from the Palatinate to New Jersey and Pennsylvania, and French Huguenots to the Carolinas-A medley of religious faiths, customs, conditions, and nationalities, with the English ever the dominant spirit-And always was love, of husband or family, the motive that led woman voluntarily to seek pioneer life on the new continent.

UT of hearthstone traditions and fireside tales comes the warp or woof of history. But for the sidelights which they present, history would be only a bare chronicle of events-succeeding periods of rule and misrule, of peace and war, of oppression by the strong and resistance by the weak. It is the personal pigment of human interest that lends warmth and colour to the whole fabric-the 


\section{4 Dioneer SMothers of America}

homely tale, of heroic endeavour for life, or cause, or family, of resourcefulness in the face of danger, of fortitude or of patriotism, that animates the grim skeleton and clothes it with living, pulsing flesh.

Our American history has one distinguishing characteristic. In most civilised countries these old fireside traditions reach so far back into the dim and hazy past, that the gossamer threads of fancy are inseparably interwoven into the sturdy fibres of fact. We, on the contrary, with but three centuries of existence, have pictures of the men and women of our early days and of the stirring events of which they were a part, as vivid and clear cut as silhouettes.

It is of the women we write-the pioneer mothers of our nation, themselves the daughters of many races, gathered from many lands, of many religious faiths and social conditions. Mostly, they came from the four great nations of Europe, Spain, Great Britain, France, and Holland, and all actuated by the same motive. For while father, husband, or lover may have been lured to these strange shores of a new world by a thirst for gold, as came the conquistadores 


\section{Emerican Tratomanbood}

of Spain, for the love of adventure, as came the English to the shores of Virginia, for freedom of religious worship, as came the Pilgrims and Puritans to New England, the Quakers to Pennsylvania, the Catholics to Maryland, and the Huguenots to the Carolinas, or to establish trading posts, as came the Dutch merchants from Holland, it can safely be said that love was the dominating influence that brought the woman, from whatever country she came or whatever race she sprang. To the man she loved, the woman has always said, as Ruth said to Naomi: "Whither thou goest, I will go."

"Women," says the historian Gayarré, "if left free to obey the noble instincts implanted within their hearts by the Creator and not checked or perverted by evil influences or circumstances, have seldom failed in any civilised country to splendidly accomplish the part assigned to their sex in helping onward the progressive destinies of the human race."

In no age, in no country, have women risen to nobler heights or filled to fuller measure the opportunities given them for forwarding the destinies of the race, than those pioneer mothers 
of our Colonial days. Hardships they suffered undoubtedly-cold and hunger at times, dangers from savage animals and more savage men; sickness and disease incident to changed climate and conditions, and always that yearning after old associations, that home-sickness that saps heart and courage from the stoutest. But there were compensations. There was the ever brightening prospect of owning homes, of having their own acres to till, of reaping their own harvest and enjoying all the fruits of their own labour. The pioneers had the blessed privilege of working together, father, mother, and offspring, all for the one object-the building of a home. There were wild beasts to face, but the mastery of these meant food or clothing. The streams teemed with fish and the forest with game and no royal game warden was there to shoot the poacher or hale him to the gaol. And always there was that growing sense of freedom, that self-satisfaction that comes to the man who feels that he is master of his environment-the "captain of his soul."

And civilised Europe, itself, in the opening years of the seventeenth century, had not so much to offer of creature comfort, prosperity, or 


\section{Elmerican Tulomanbood}

hope, for peasant or yeoman, improvident adventurers, impecunious younger sons or other "poor relations," who, with the refugees of the debtors' prisons and workhouses and the victims of crimping ship-captains, went to swell the numbers of those who first sought the shores of the new continent. For feudalism, for centuries the enemy of human rights and human progress, still held all Europe in its paralysing grasp. The nobility oppressed the common people to a degree scarcely conceivable in our day-an oppression that was breeding for France the bloodiest revolution in history. The man of low degree, especially in France or Spain, was but a serf, and his personal safety, his property, and the sanctity of his home depended more on the strength of his right arm than upon any protection afforded him by the law. Great Britain, and indeed all Europe, was rent with religious wars and factional quarrels over creeds and dogmas, and persecution was rife on every hand.

Of course, it took time for these colonists to adjust themselves to their changed conditions in life, to throw off the feudal idea of master and man, and long years to outgrow the ignor- 
ance and superstition and religious bigotry to which they had been born. And ever there was some stern, unbending soul, filled with fanatical zeal, through the light as he saw it, who must needs drive his fellow-men to worship his god and in his narrow way. But always we find them groping blindly toward light and liberty; always there was something apparent in the free air of the new continent that was developing the spirit of progress and independence necessary to a race of freemen.

The first English women to come to America were of the Colony sent over in 1587 by Sir Walter Raleigh. There were seventeen of these, and to the Governor, John White, came a little granddaughter, Virginia Dare, the first English child born this side of the water. Of her fate no one knows. The Colony was planted and later Governor White sailed back to England for supplies and more colonists. England was at war with Spain, and the Spanish Armada was threatening to drive the English navy off the seas. Captain White's vessel was pressed into service and it was three years before he was able to sail back to Roanoke Island. No trace of the settlement remained nor was any- 


\section{American Vulomanbood}

thing definite ever learned of the little band of colonists. Whether little Virginia Dare perished of disease or hunger, or lived to wed some Indian brave and rear his dusky brood, is one of the mysteries of "The Lost Isle of Roanoke" which no man may know. If the latter was the case, hers was not the only mating between the red race and the white in the early history of Virginia.

Pocahontas, daughter of Powhatan, the Indian girl who saved the life of Captain John Smith and later that of the little settlement of Jamestown, is a character whose story is familiar to every schoolchild. Her marriage to John Rolfe, a young tobacco planter, was the first romance of America, as Pocahontas was the first Indian woman known to have embraced the Christian religion. Rolfe carried his Indian bride to England where she became a social sensation. She was presented at Court, fêted and petted by the nobility, always winning praise for her gentle, modest demeanour and lovable character. Through her son, the blood of the Indian girl is mingled with some of the best and bluest of the Old Dominion, and "Our Lady of the James" will live long in the hearts of all Virginians. 
This same John Rolfe looms large in the history of the infant Colony of Jamestown, first planted in $\mathrm{I} 607$, for it was he who conceived the idea of raising tobacco as the Indians raised it and selling the product in England where the weed had come to be in great demand. So successful was the venture that by I6I6 tobacco had come to be the recognised medium of trade in all sorts of commercial transactions and so continued for a century and a half. This bit of trade history has a bearing upon the development of the women of the Colony of Virginia the importance of which will appear later.

The men who came to Jamestown and the other earlier settlements of Virginia, younger sons, penniless adventurers, and soldiers of fortune, were mostly unmarried. They came to Virginia as our forty-niners went to California, something more than two centuries later. They did not find the gold they sought but land for the taking, as picturesque and fruitful as any in England, with a climate to vie with that of sunny France. Sorely disappointed when the shipload of golden sand which they had shipped to the mother country proved to be but "fools' 


\section{Elmerican Vulomanbood}

gold," many of the younger men were ready to turn to planting. Especially was this so when they were brought to see the fortunes that lay in the cultivation of tobacco, which the English were then buying from the Spaniards. With these dreams of permanent homes and landed estates, there came naturally a longing for the companionship of the other sex. There were but few unmarried women among the colonists and but one dusky princess was found ready to gladden the home of a husband, so the young colonists were driven to marry the girls sent over by the promoters of the Colony in London. The chronicles are not very clear about this transaction, but it is agreed that "they were comely young women of good character" and that they sold readily as wives. That is, they were practically sold, as the young planter who wanted to wed one of the girls was obliged, first, to win her consent and then to pay one hundred pounds of tobacco to cover the cost of her passage. There were a number of other girls who had been kidnapped by shipmasters and brought over and sold in the same way. Many a prosperous and lonely young planter fell in love with one of these homeless girls and married her, and 
it is on record that they made good wives in the main, as did their French sisters, the filles de cassette, whom King Louis XIV. half a century later sent over to the Ursuline sisters at Bienville's Colony near the mouth of the Mississippi, to be disposed of as wives. Each of the French maids, it is said. was supplied with a small chest of clothing from the King's bounty: (hence the name), and many a proud old Creole family of New Orleans traces its ancestry back to one of the "casket girls."

The young English women sent over to Jamestown were known as the "orphan girls"; there were twenty in the first consignment, and by 1619, in all, two hundred. Afterwards there were others, and the price went up to one hundred and fifty pounds of tobacco as passage money. How many of these young women were sent into the Colony, or how many girls were kidnapped and brought over by unscrupulous shipmasters, can only be conjectured.

It was not until after many hardships and many mistakes, out of which grew the wisdom of experience, that success came, and a few years later we read that the banks of the James for a distance of one hundred and forty miles was 


\section{Emerican Tromanbood}

given over to tobacco plantations, and each incoming ship bore its little colony of immigrants, including women and children. From a camp of shiftless adventurers, Virginia had become a colony of ambitious planters with comfortable homes and growing families.

So it was that the Old Dominion began working out her splendid destiny. So it was that on the anvil of adversity these ne'er-do-wells, portionless younger sons and cast-off poor relations, these fortune-hunters and brokendown gentlemen, were being annealed and tempered into the citizenship that was to produce the Washingtons and Jeffersons, the Lees and Randolphs, and those other knightly men, soldiers and statesmen, who were so much a part of the upbuilding of our nation. And remember, that it was upon this same anvil that there was being fashioned from the raw, crude, and generally unlettered, though "virtuous young women," whom the Virginia Company in London had gathered up and traded for tobacco, the characters of the mothers of many of the men who were to become pillars in the new temple of liberty. And who shall say that the sturdy, tobacco-bought, plebeian blood was 


\section{I4 Dioneer Mothers of America}

not fully as essential in the making of the new civilisation as that of the gentility, effete though this had become, with which it was forced to mate?

It was at this time, I620, a year alter the Holland shipmasters had sold their first cargo of negro slaves to the planters of Jamestown, that another English colony was established in America-another colony which was destined to breed men and women who were to play great parts in the drama of civilisation. But these Pilgrim fathers, who, after failing to find in Holland that measure of religious freedom which had been denied them in England, had steered their Mayflower to the bleak New England coast, were of far different material from the pleasure-loving Cavaliers and adventurers and their tobacco-bought wives of Virginia. The Pilgrims and the Puritans who followed them were an austere people, who attributed to an evil source all charms of personality and the most rational pleasures, who had yet to learn that graciousness was one of the Christian virtues, and who, though forced to flee from religious intolerance, had also yet to learn the lesson of tolerance. It was at a 


\section{Elmerican Traomanbood}

terrible cost that they were to master this lesson-the shades of Ann Hutchinson and her murdered family crying from the wilderness, and the moans of the whipped and bleeding Quakers and of many other victims of persecution, could tell how terrible. But the lesson was mastered at last, and being of the stern set, and unyielding race they were, the Puritans made religious liberty for all one of the tenets of their creed, and stood as ready to shed their blood in defence of the principle as they did in defence of their own faith. It was a blind groping toward the light-one of the object lessons, like the outbreak against witchcraft in New England and New York, by which the direct and simple-minded men and women of these little Colonial settlements were being taught the inherent rights of man.

Between the coming of these two English colonies, the Cavalier and the Puritan, there had been planted, in New Amsterdam, a settlement of another nationality-thrifty, phlegmatic Hollanders, sent out by the Dutch West India Company, which, in exploiting its vast claims in the New Netherlands, gave most generously of its territory to wealthy men, who 


\section{I6 Dioneer Sotbers of America}

could equip and settle a colony. These early Dutch settlers came with many of the creature comforts that most other pioneers could not command. The Dutch West India Company wanted trading posts where it could traffic with the Indians, selling them goods and buying their furs, while waiting for their navigators to discover the Northwest passage. Soon these Dutch were to push their trading posts to the north and establish their great manors as far up the Hudson as the mouth of the Mohawk. Soon were to come the Quakers and other nonconformists into Pennsylvania, seeking refuge from persecution; the Puritans into Connecticut, and the Catholics into Maryland, where they were to plant a colony that by its religious tolerance was to shame the Protestants.

The Spanish in North America were ever more successful in spoliation than colonisation. Fifty years after Ponce de Leon, pursuing his will-o'-the-wisp, the Fountain of Eternal Youth, had discovered Florida and twelve years before Raleigh's colony came to Roanoke, the Spanish established a little colony at St. Augustine and, seventeen years later, one at Santa Fé, New Mexico. These two towns, the oldest in the 


\section{Emerican vellomanbood}

United States, like the little French settlement near the mouth of the Mississippi, were eventually to become a part of the new nation which was in the making.

For it was out of this medley of nationalities, this mixture of types: pleasure-loving aristocrats, religious refugees, thrifty traders, disappointed gold-seekers, banished law-breakers and adventurers, bonded working men and their women of as many races, sorts, and conditions, that a new people were being made. It was from such beginnings as these that there sprang the staunch and steadfast pioneer women who a century later were making possible a nation of freemen. It was such frontier conditions as these colonists were called upon to meet that were to develop the splendid women of 1776 , without whom the Revolution must have been a failure. 
$A^{M E R I C A}$ is God's crucible, the great melting pot, where all the races of Europe are fusing and re-forming. 'Here you stand, good folk,' think I, when I see them at Ellis Island; 'here you stand in your fifty groups, with your fifty languages and your histories, and your fifty blood hatreds and rivalries, but you won't be long like that, brothers, for these are the fires of God you have come to; these are the fires of God. A fig for your feuds and vendettas, Germans and Frenchmen, Irishmen and Englishmen, Jews and Russians, into the crucible with you all, God is making the American." "-Zangwill. 



\section{Chapter I}

\section{The Thomen of Dioneer Days}

Through the hardships and dangers, the sorrows and joys of pioneer life woman came to walk shoulder to shoulder with man, sharing his labours in forest and field, as well as his cares and compensations at home-Necessity compelled her to become man's real helpmeet, and their association and isolation led to their mental development along similar lines-Together they developed the same sturdy, alert self-reliance, the same independence and courage-Together they faced the mal-administration of Colonial governors in whose appointment they had no part, and the constant encroachment of the Crown's representatives upon their inherent rights and privileges-The natural evolution of the brave, patriotic, and high-spirited dames and daughters of Colonial days.

T $\mathrm{N}$ speaking of pre-Revolutionary times, we are apt to confound Colonial days with 1 pioneer hardships. It is difficult to disassociate the privations and dangers incidental to frontier settlements from the comfortable affluence and safety of older communities; difficult to realise that the thirteen Colonies, in the latter half of the eighteenth century, had already grown to a big and prosperous country with a population of nearly two millions. Natur- 
ally, as it was a new country and growing rapidly, there was always a frontier where wild animals prowled in the depths of the woods and log cabins had to be built and land cleared before a crop could be planted or garnered. But the Colonies, beginning at the coast line, had already crept back many leagues into the Appalachians, with a sturdy band of pioneers ever at the forefront adding new acreage to the king's dominions. And along the coast line of all that country first settled had grown up towns, villages, and farmsteads, where peace and plenty had seemingly found a safe abiding-place.

The fourscore years that were to elapse between the settlement at Plymouth, in I620, and the beginning of the eighteenth century, were fraught with vast promise for the new world, however little it might be realised by the little band of English adventurers who had built their palisadoed camp at the mouth of the James, and the handful of fur traders who had set up their trading post at the mouth of the Hudson, or that other little group of religious refugees who were shivering on the shallow shores of Cape Cod Bay.

At the opening of the seventeenth century, 


\section{The Whomen of Dioneer Dapg}

neither the English nor the French had planted any stable colony in America, and the settlements that had been located north of the Gulf of Mexico were those of the Spaniards at St. Augustine and Santa Fé. In 1605, however, the French had set up a little colony at Port Royal in Nova Scotia and three years later another at Quebec. These, with the English settlements at Jamestown and Plymouth, and the Dutch trading post at New Amsterdam, constituted the entire white population north of the Gulf. No one of the European nations seems to have had any idea of the immensity of the continent. France claimed everything south of the St. Lawrence River, the English parcelled out their grants "from the Atlantic coast westward," and the Spanish claimed everything north of their Gulf settlements. Naturally these claims and those of the Dutch to New Netherland overlapped, and this produced endless confusion. While the first few settlements were separated by hundreds of miles of forest, this was of little moment, but as the settlements increased, the rival claims became a source of constant strife, ending eventually in the control by the English of all 


\section{Dioneer Sibothers of America}

the Colonies between Florida and Nova Scotia on the Atlantic coast.

Following closely on the heels of the Pilgrims, there came a vast immigration to AmericaCatholics and Non-conformists from England and Scotland, and Protestants from the Catholic countries of the Continent. Indeed, the new world, was largely peopled by reason of the religious dissensions and persecutions of the old. In consequence, the Colonies did not have to evolve and build up a new civilisation from raw and untrained material, but rather took up the old, with a free hand to prune off excrescences and to perfect inadequacies. In the main, these settlements were made by small religious bodies -congregations like that of Plymouth, where the pastor accompanied his flock, and there was but little break in the well-ordered regularity of their lives. It was to be expected that these men and women, most of whom had left home and country because they would not be dominated in matters pertaining to their religious faith, would not rest until some semblance of law and order was established, and that their first aim after food and shelter would be the church and the school. 


\section{The trlomen of Dioneer Daus}

A brief glance at the beginning of some of these Colonies may not be out of place. Eight years after the founding of Plymouth, John Endicott and five associates obtained under a charter from Charles I. a grant of land about Massachusetts Bay, and many Puritan families "flocked to the land of liberty." Some gathered around Governor Endicott, who founded Salem and Charlestown; some established Colonies in Dorchester and Watertown; and others, under John Winthrop, in I630, settled Boston. Many of the leading men of the movement were well to do and these Colonies were better prepared to face life in a new country than had been the Pilgrims at Cape Cod Bay. In I635, a settlement was begun at Hartford, and the following year Rev. Thomas Hooker and the main body of his congregation, driving their flocks before them, travelled through the wilderness and made the settlement permanent and prosperous. In the meantime, John Winthrop had built a fort at the mouth of the Connecticut to shut out the Dutch, who were already claiming the territory, and planted a colony there which he named Saybrook. This was afterward sold to the Colony of Connecticut, which 
comprised Hartford, Windsor, and Wethersfield. It was the Connecticut Colony that adopted a written constitution in which was given all freemen the right to vote, "the first instance in history of a written constitution framed by the people for the people." In I662, both Colonies were united under a royal charter which guaranteed to the colonists all the rights upon which they had agreed.

In I643; a union was effected of the Colonies of Massachusetts Bay, Plymouth, New Haven, and Connecticut. The main object was a defensive league against the Indians and also against the encroachments of the French and Dutch. About two years after the settlement of Plymouth, two or three little settlements were begun along the coast, between the mouths of the Kennebec and Merrimac rivers, on a private grant which eventually came under control of Massachusetts and later were parts of New Hampshire and Maine. Rhode Island was settled in I 636 by Roger Williams, a clergyman whose liberal views were not in accord with those of the Puritans of Massachusetts Bay. The Colony wanted to join the New England Union but was refused admittance because it 


\section{The turnen of Dioneer Daps}

had no charter. Williams at once went to England where he succeeded in getting a charter under which the people proceeded to elect officers and enact a set of laws guaranteeing freedom of faith and worship to all. This was the "first legal declaration of liberty of conscience ever adopted either in Europe or America."

Although the Dutch had in I6I3 laid claim, by right of discovery, to Manhattan Island, they had not attempted a real settlement until I624, when Jesse DeForest brought thirty families of Belgian Protestants, or Walloons, on the ship New Netherland, and landed them at Walloon's Boght, or Bend, now Wallabout, Brooklyn. Eighteen of the families went up the Hudson and settled near where later was established Fort Orange (Albany). The others settled on Long Island and across the river on Manhattan Island. Two years later, Peter Minuit, the first of the Dutch governors, came over with a shipload of colonists from Holland. Minuit bought Manhattan Island from the Indians and founded New Amsterdam, but it was several years before either Manhattan or Rensselaerwyck, the first of the great patrooneries, began to take on the semblance of a real settlement. The 
Dutch claimed New Jersey, and as early as I6I 8 had established a trading post at Bergen. When the Duke of York took New Netherland, he gave the land between the Hudson and the Delaware rivers to Lord Berkeley and Sir George Carteret, and in I664 a company from New England and Long Island established a settlement at Elizabethtown, the first permanent settlement in the Colony. Lord Berkeley sold his half of the grant, West Jersey, to some English Quakers and a company of that faith started a settlement at Burlington. Sir George Carteret sold East Jersey to William Penn and eleven other Quakers. It was peopled, however, very largely by Puritans from New England and by Scotch-Irish Presbyterians. In 1638, a company of Swedish Protestants settled on a tract which they called New Sweden, near what is now Wilmington, Delaware. The same people also started the first settlement in Pennsylvania, a short distance below the site of Philadelphia. In I682, William Penn secured from Charles II. a grant of the land lying west of the Delaware River, as a refuge for the Quakers, and in 1683 he founded the city of Philadelphia, which in two years grew to a population of over two thousand. 


\section{The Tulomen of Dioneer Daps}

Maryland was founded in 1634 , by Cecil Calvert, Lord Baltimore, the first settlement being made at St. Mary's, an Indian village near the mouth of the Potomac. Calvert's purpose was to secure a refuge for the Catholics who were being persecuted in England. The charter under which Calvert's grant was given promised all freemen a voice in the making of the laws. An Assembly called, in accordance with the provisions of this charter, in I649 passed the celebrated Toleration Act, which secured to all Christians "the right to worship God according to the dictates of their own conscience." Twice afterward, when the Protestants in the Colony attained a majority in the Assembly, the Catholics were disfranchised. For years, the Colony was in a turmoil, until in I 7 I 5 when religious toleration was restored.

Albemarle Colony, afterward North Carolina, was first settled early in the 'sixties by people from Virginia and a governor from their own number set over them. Carteret Colony, afterward South Carolina, was established in I670 by English emigrants. A settlement was first started on the Ashley River, ${ }^{\mathrm{I}}$ but did not take

I The reference figures in the text refer to notes at the end of the several chapters. 


\section{0 \\ Pioneer Mothers of America}

root, and afterward was removed to the site of the present city of Charleston. Its growth was rapid. Shiploads of dissatisfied Dutch people from New York, after the occupation of the city by the English, came to the Colony, as well as thousands of French Huguenots, followed closely by many Scotch-Irish Presbyterians and other religious refugees, a sturdy, independent stock, which fast pushed the Colony to prosperity. Georgia, the last of the thirteen Colonies to be established, was not colonised until I732, when George II. granted to General James Oglethorpe a tract of land "in trust for the poor," and a year later a settlement was effected at Savannah. Oglethorpe's first purpose was to make an asylum for the inmates of the debtors' prisons and others oppressed by the severe laws against debtors. A large number of Moravians, Lutheran Salzburghers, and Scotch Highlanders were among the first settlers, and the Colony fast grew in population and importance.

Agriculture was the main occupation of the people in the latter part of the eighteenth century, though there was some attempt at manufacturing, especially in the northern Colonies. Cloth weaving had been tried, but as most of the people 


\section{The Tamen of Dioneer Daps}

dressed in homespun, and spinning and weaving was a part of the work of most households, there was little demand for the output, which if sold must be disposed of contrary to law. Commerce in the Colonies had steadily increased, but was confined mainly to the coast trade, owing to oppressive laws. New England fishermen, in addition to their vast catches of cod and mackerel, were pushing their whaling vessels far up the northern coast, and whale oil, dried codfish, and rum, manufactured from West Indian molasses, were as much staples of Massachusetts as was tobacco of Virginia. Considerable shipbuilding was carried on along the New England coast, but the industry was frowned upon by England as detrimental to her shipbuilders and American-built shipping could not enter into the foreign trade. In fact, Great Britain had repressed the mechanical arts in the Colonies almost as effectually as she had the commerce. In so doing, however, she had developed from her Colonial agriculturists a nation of mechanics. The farmhouse was the manufactory wherein were made most of the articles of daily use. Clothing, bedding, shoes, harness, household furniture, and agricultural 
implements were made at home. From the Indians, the settlers had learned to dress and tan the skins of animals, and from these they fashioned robes and rugs, fur garments and leather. From the Indians, they had learned also to make splints from the black ash, and the manufacture of chair bottoms, baskets, and winnowing pans was work for the long winter evenings. Even nails were pounded out at home from rod iron of English importation. In their more primitive days, while yet the colonists were practically homeless, they had learned many lessons from the aborigines. In Virginia, at Jamestown, the first comers had borrowed from the natives the idea of the roof of red cedar bark for their log cabins. In Massachusetts, many of the poorer settlers had lived in wigwams and brushwood tents which friendly Indians taught them to build. The Quakers in West Jersey, spent their first winter in Indian caves and dug-outs, and in Maryland it is recorded that the first settlers shared an Indian village with its owners, who gave them not only shelter but food. This primitive housing was but one of the many things the red men taught the white. Probably 


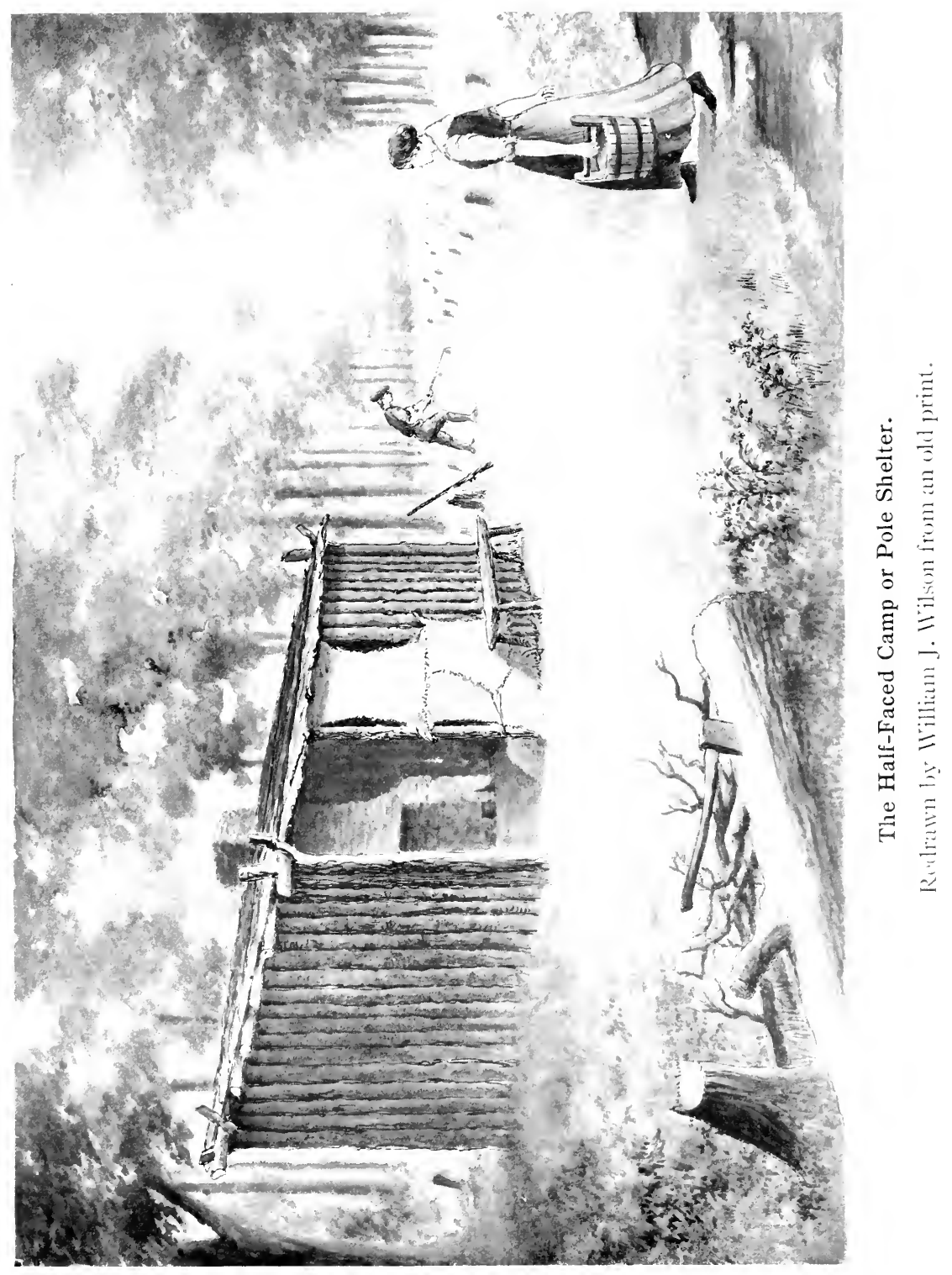





\section{The Wulomen of Dioneer Daps}

the most beneficial was the cultivation and use of maize. Indian corn was the first grain raised by the pioneers, and together with fish and game formed the greater part of their sustenance. The Indian woman taught the white to pound her corn in a hollow stone, mix with water, and bake the cake on a flat stone before the fire. The settler improved on this by rigging a mortar and pestle to bruise the grain, and then set the cake to bake on the broad blade of his shovel or hoe, thus giving name to the "hoe cake," still baked in the cabins of the south and west. From the Indian woman, the white learned to soak her shelled corn in the lye of wood ashes and remove the woody hull, and "hulled corn" became a staple article of pioneer food, as did another dish of Indian preparation, beans baked in an earthen dish set in the hot ashes. It was the Indians who taught the settlers of the northern Colonies the making of sugar from the sap of the maple. And all these crude lessons were improved upon by the settlers, who developed their own resourcefulness as they developed their borrowed ideas and suggestions.

In all these domestic interests and activities, we find the women taking as prominent a part 


\section{Dioneer Mothers of Elmerica}

as the men, and indeed most matters pertaining to the home came to be left almost entirely to her. It was the woman who clothed the family from the raw materials. It was the woman who fed the family from what the man provided or with such makeshifts as her pioneer knowledge or industry could furnish, and it was the woman on the frontier who from her pharmacopœia of roots and herbs was called upon to minister to the ailments of the family. And ever we find the woman broadening and strengthening under her burden, ever rising to meet the responsibilities thrust upon her.

We find also that this prominence of the woman is not lessened as we pass from the log cabins of the frontier to the more pretentious homes of the wealthy planters or prosperous farmers. Whether in the half-feudal manors of New York or New Jersey, the Colonial mansions of the great landed proprietors of Virginia, Maryland, or the Carolinas, or the commodious homes of the well-to-do farmers or rich merchants of Connecticut and Massachusetts, always do we find the woman doing her share of the work and bearing her share of the responsibility. 


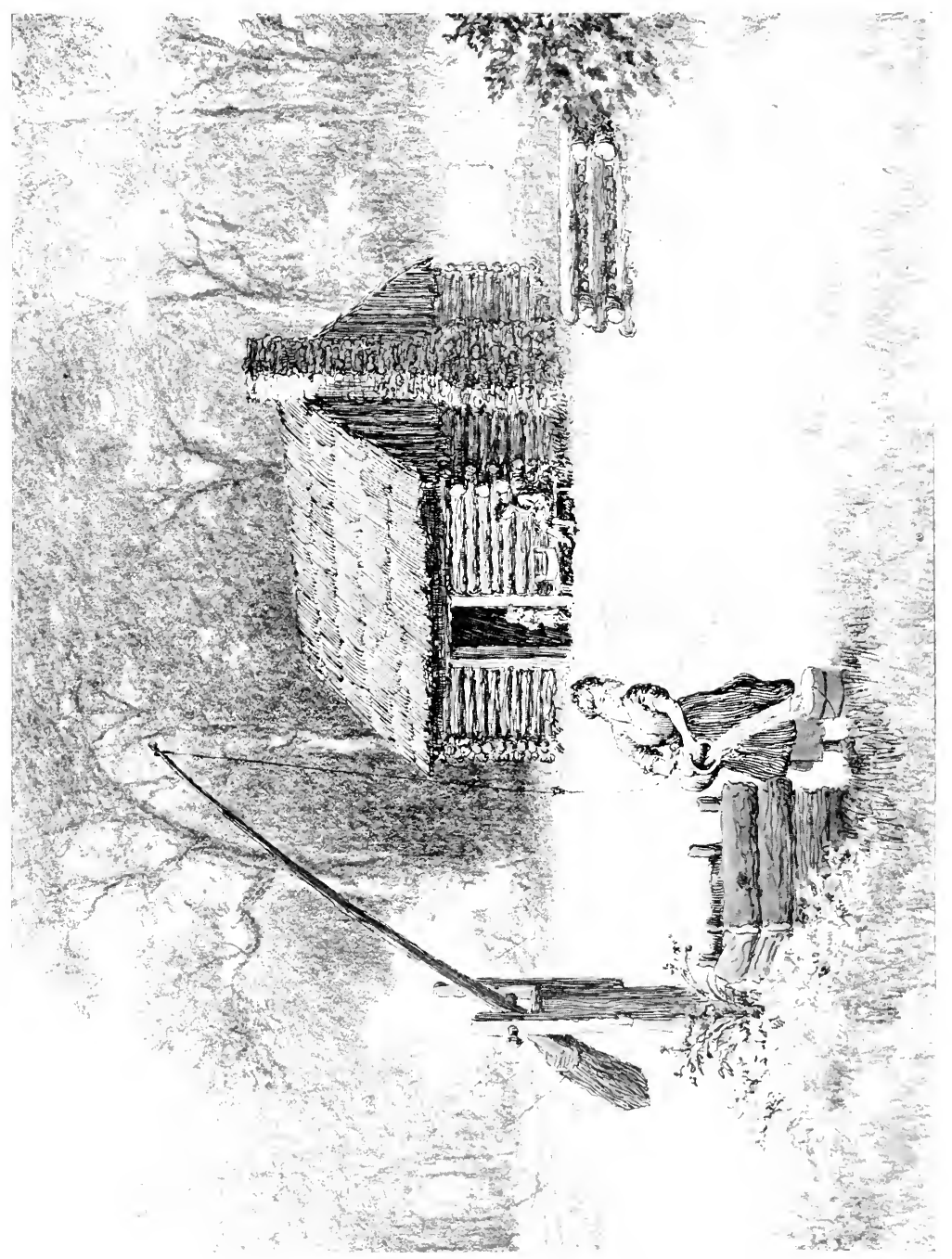

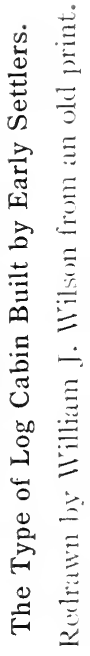





\section{The VClomen of Pioneer Daus}

In the latter part of the Colonial period, each of the Colonies still maintained more or less marked individuality, yet all had come to have much in common. The intolerant religious spirit of the early days was passing away and there was a gradual assimilation of manners and customs. Of course, the ideas and tastes of the mother country, which the colonists brought with them, long survived, notwithstanding the levelling tendencies and broader spirit of the new world. For instance, the distinctions in dress that marked the higher and lower ranks of society were carefully maintained, even in democratic New England. Only the gentry could wear calfskin shoes, those of the servant class being restricted to the coarser neat's leather. Working men generally, farmers, mechanics, and labourers, customarily wore coloured baize jackets over checked shirts, with canvas ticking or leather breeches, home-knit woollen hose, and cowhide shoes. On Sundays or holidays a white shirt might be worn instead of a checked, and the breeches would likely be of leather, greased and blackened until they shone. Brass buckles might be worn on the shoes, but not silver. The women of the same class wore 


\section{Pioneer Smothers of Elmerica}

short gowns of bright coloured baize and petticoats of linsey-woolsey.

Gentlemen of Colonial days wore gay coloured silks, handsomely embroidered velvets, silken hose, with gold or silver buckles on their shoes, and broad bands of fine lace at their wrists. Most of the gentry sent to England for their clothing, and men and women, so far as they were able, followed the fashions of the English Court. In some of the Colonies these matters were partially regulated by law." No person whose estate did not exceed £200 could wear "gold or silver lace exceeding in cost $2 s$. per yard." The selectmen of Connecticut were required to take note of the apparel of the people, especially of their "ribbands and great boots." The prefix of "Mr." and "Mrs." were accorded only to the gentry, including ministers and their wives. Throughout New England, official positions were generally filled by a few leading families and were often handed down from father to son, for generations. The catalogues of Harvard and Yale colleges were for many years arranged according to the family rank of the students. This line of demarcation between persons of "gentle birth" and the so- 


\section{The trhomen of Dioneer Daps}

called "lower classes" was still more sharply drawn in New York and Virginia and the southern Colonies.

From their earliest days, there was in nearly all the Colonies a decided effort toward education. Naturally this was most marked in New England, the Puritans ever holding education next to their religious freedom. Whether it was among the well-to-do farmers of the northern Colonies or the wealthy planters of Virginia, Maryland, and the Carolinas, as soon as the pioneer stage was passed and the colonists found themselves well enough established that the primal objects of food and shelter were assured, their thoughts turned to the moral and. mental upbringing of their children. The first of these was largely determined by the religious bent of the parents, and churchly creeds and catechisms entered far more into the daily lives of the people in those days than in ours, and religion, or at least the outward expression of religion, was proportionately more prevalent. But in the matter of secular education, "book learning," they called it, the settlers all wanted their children to have greater advantages than they themselves had enjoyed. In most countries of the old world, 
the idea still prevailed that any attempt to educate the "lower classes" was harmful alike to them and to society at large; tending to make them dissatisfied with their condition in life and encouraging them to ideas and ambitions "above their place." Naturally illiteracy was the rule rather than the exception as now. But in the hard and strenuous life of the new world these ideas of caste and birth and social superiority were fast being shattered. The thrifty pioneer of peasant birth or ancestry, who had cleared his acres, raised his crops, provided for his family, and paid his debts, came to feel himself as worthy a man as his neighbour of gentler birth who had done no more. And we may be sure that his wife put these thoughts into words, if he did not, and insisted that their children must be educated not only as well as those of their neighbour, but as well as lay in their power.

In that old world from which they or their forebears had come, even among the gentry, the education of women had been looked upon as an unnecessary and perhaps undesirable accomplishment, something calculated to make her "dissatisfied" and forgetful of "her place" in the family or community. Now, the pioneer 


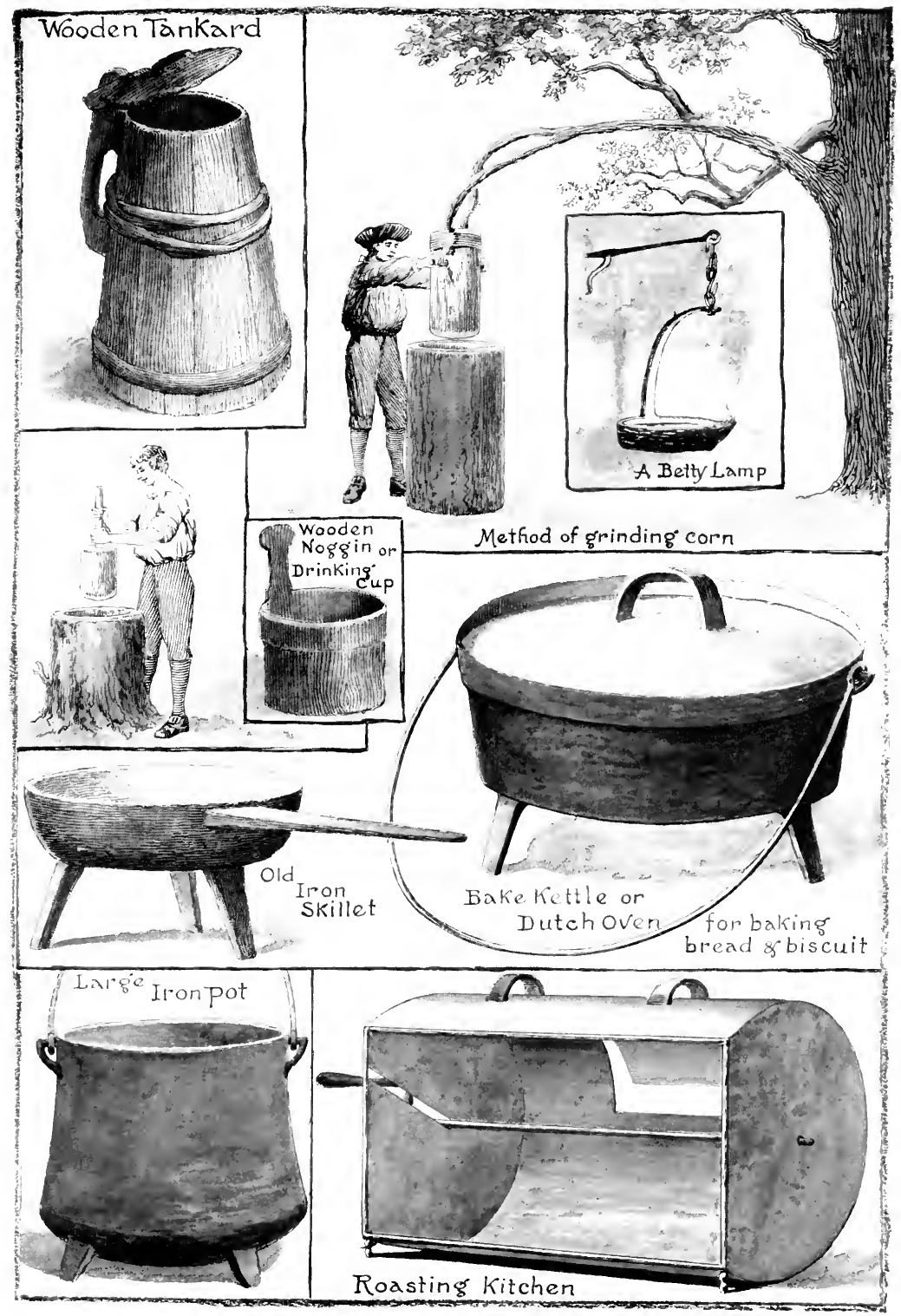

Household Utensils Used by the Settlers.

Drawn from old prints. 



\section{The rulomen of Dioneer Daps}

woman had come to know "her place." By rugged experience she had come to know that her place was beside her husband, not behind himbeside him in the field, in toil, in danger and hardships, beside him in all the responsibilities of pioneer life, and she felt that if her daughters were to fill similar places, they needed all the education they could command. And so it was that the girls of pioneer days began to receive about as much of "book learning" as their brothers. Though she did not realise it, this pioneer mother of the log cabin was learning something of her own rights and responsibilities - was paving the way for that educational emancipation of women that was bound to come.

As yet there was no thought of higher education for women, except such as she might get from private tutors, though there were several colleges for the higher education of men, the first of which was Harvard, founded in 1636 ; but none of these admitted women.

There were schools, however, and in Massachusetts, in 1647 , we find each town ordered to maintain a free school, and if the town had a population of one hundred families it must support a grammar school. In Connecticut, at about the 


\section{Dioneer Mothers of America}

same period, every town had to have a free school, which must be kept open three months of the year or the town was subject to a fine. There were schools in New York as far back as during the Dutch occupancy and Dutch schoolmasters who, besides instructing the young, rang the church bell, acted as town clerks, choristers, and public readers. One of these old schoolmasters of New Amsterdam, who advertised to "teach English as an accomplishment," was continued in the teaching part of his calling after the English had taken over the Colony. In I702, an act was passed in the New York Assembly for "The Encouragement of a Grammar Free School in the City of New York." Pennsylvania's first school, of which we have record, was started in I683, and "reading, writing, and casting accounts" were taught for "eight shillings per annum." In the southern Colonies, and especially in Virginia, the English governors mostly showed more or less opposition to anything like general education, though a free school was started as early as in $16 \mathrm{I} 7$, which half a century later was to be the second college founded in America. ${ }^{3}$ Governor Berkeley of Virginia is quoted as saying: "Thank God, there 


\section{The Wumen of Dioneer Daps}

are no free schools nor printing-presses here, and I hope there will be none in a hundred years." But in Virginia there were private schools to be found in every large community, as there were at an early date in Maryland and the Carolinas, and private tutors and governesses were secured by most of the wealthy planters for their children. Free schools were established in Maryland in 1696, and we know that there was a free school in Charleston in I 72.

The first printing-press was set up in Cambridge in 1639 , three years after the establishment of Harvard College. The first permanent newspaper, the Boston News Letter, was published in 1704. Virginia had no newspaper until 1736, four years after William Bradford had established the Weekly Gazette in New York. In I750, there were seven newspapers in the Colonies, which number had, in 1775 , increased to thirty-seven.

This, in brief, was the general condition of educational matters in all the Colonies, in the years between the French and Indian wars and the Revolution. It does not perhaps indicate any high degree of mental progress compared with conditions as they are to-day, but 
when compared with what existed at that time in every country in Europe, the colonists, crude and unlettered as they must have been, had certainly a high standard of morality and education.

A rarely interesting study is the development of these pioneer women under their new world environment, their steady growth in those elevating and ennobling qualities that go to build up and strengthen character. During all the ages of civilisation and semi-civilisation, it had been the man who had gone out to fight the great battles, while the woman was left behind to the lesser affairs of domestic life. She may have been the toy or the drudge of either master or man, but whether she came from castle or cabin, she was always the sheltered one, hedged about and restrained by customs and conventionalities from any active participation in the greater affairs of human endeavour. Man praised her youth, her beauty, or her accomplishments, and these past, she retained his regard by ministering to his wants. Ever her horizon was narrowed, ever her emotions were fostered, but rarely her sense of justice, her keenness of judgment, her firmness, her courage, or her resolution. 


\section{The Vulomen of Dioneer Dans}

Probably there was never a period in all history when men and women were brought closer together in purpose and understanding than at the outbreak of the Revolution and during the years of gradual encroachment of King and Parliament upon the rights and liberties of the people, of which the Stamp Act and the tax on tea were but the final straws. In the pioneer days this had to be. The man and woman were working together, with but a single purpose-to build a home, to feed and clothe and rear their family, and to worship God as to them seemed best. The very isolation of their lives brought them into almost patriarchal companionship, but with the difference that the woman had come to hold a far more important place in the home than she had ever held in the tents of the patriarchs. In their earlier days, the wife of the pioneer was often called upon to work with her husband in forest or field, to plant or reap their scanty crop, to fell or girdle trees in their little clearing, to burn the fallen timber, to care for their live-stock. She faced the same dangers that he faced from lurking Indian or prowling animal and learned to take the same precautions to safeguard her home and family. 


\section{0 Dioneer Sothers of America}

She came to know that the Indian had no respect for age or sex and would scalp her or her babe as readily as he would her husband. In short, she became the bold, self-reliant, and resourceful frontiers-woman-the kind that helped carry American civilisation to the Pacific coast within half a century of independence.

But always the man and the woman worked together and planned together and together thought out the solution of such problems as came into their simple lives. And in that stretch of years leading up to I 776 each Colony had its own problems to solve-its own measure of trials and tribulations.

First and always, on the frontier, was the Indian. Even in peace and when counted as "friendly," the Indians were a constant menace. Their ways were not the white man's ways, and it was rarely that the two came to an understanding of the rights or motives of each other. Ever there was a lurking suspicion on either side, a sullen ill-nature ready to spring to anger and quick retaliation of any injury, real or fancied. And not always was the Indian in the wrong, though it was always the women and children who had to suffer when unscrupulous 


\section{The rulomen of Dioneer Daps}

traders sold rum to the Indians or robbed them in their bargaining. Constantly there were petty depredations, and occasionally a family murdered or defenceless small settlement laid waste, but these were as nothing to the havoc wrought by the inter-colonial wars. From I689 until I764, a period of seventy-four years, there were no less than four wars into which the Colonies were dragged by the politicians of Europe in furtherance of their policies.

The first was King William's war, which lasted eight years and in which the Indians of Canada and Maine were won to the side of the French. Terrible suffering followed, for the people of New England and New York. Haverhill, Schenectady, and many smaller settlements were almost depopulated by Indians who came down from across the northern borders. Then came Queen Anne's war against the French and Spanish, and again for eleven years the northern Colonies were swept by the horrors of savage warfare. Deerfield in Massachusetts and other frontier towns were harried by the French and Indians and hundreds of the inhabitants killed or carried into captivity. King George's war, which followed, lasted four years and resulted 
in nothing but the taking of Louisburg, the French stronghold on Cape Breton, by a combined force of British and Colonial troops. In this campaign the Colonials did most of the fighting and the British claimed all the glory. The last was the French and Indian war, lasting nine years, and costing the Colonies \$16,000,ooo, of which the English Government repaid only $\$ 5,000,000$. The Americans lost thirty thousand men and passed through untold suffering. The taxes growing out of the cost of this war were almost unbearable, but the price paid was, for the results secured, not too great. The campaigns had brought the Colonies into a crude defensive alliance. The men of the different Colonies had fought shoulder to shoulder, and sectional prejudices and jealousies were to a large degree forgotten. Democratic ideas had taken root that were to make possible the Revolution. The colonists had come to know their rights and how to defend them. Their legislative bodies had, of their own initiative, levied taxes, raised troops, and voted supplies, yet jealously guarded their treasuries. The Colonial had, moreover, learned something of warfare. The British officers 


\section{The Vulomen of Dioneer Daps}

had sneered at the awkwardness of the Colonials and had pushed aside their best officers to make place for young English subalterns. It is an interesting fact, that among the young American officers so slighted were Washington, Gates, Putnam, Stark, Arnold, and Morgan.

Indian wars and taxes were, however, but a small part of the troubles that these pioneer men and women had to discuss as they sat over their wood-fires in the chimney-corner. Some one has said that the period I660 to 1776 included "fifty years' rule of fools and fifty of knaves." This applied to the governors appointed by the Crown and does not appear to have been exaggerated. Excepting the proprietaries, Pennsylvania, Delaware, and Maryland, the Colonial governors were named by the English ruler. Generally selected through favouritism, they were more often weak and inefficient or unscrupulous adventurers than public-spirited and honest officials. Lord Cornbury, an early governor of New York, was a cousin of Queen Anne. $\mathrm{He}$ was also a dissolute unscrupulous man, given to such amusements as masquerading in women's clothes and consorting with 


\section{$54 \quad$ Pioneer SMothers of America}

disreputable characters. He squandered the public money and imprisoned prominent men who criticised him. His wife levied tribute on the well-to-do families whom she visited by carrying away small articles of bric-a-brac, pictures, jewelry, and silver, which she sold. When she died, Lord Cornbury paid for her funeral expenses by selling a government concession and appropriating the funds, a fact of which he openly boasted. His rapacity and utter disregard of the rights and interests of the people finally secured his recall, but not until after it had been demanded for years.

Fletcher was another New York governor with an itching palm. He sold immunity to pirates who wished to live in New York unmolested, at $£$ Ioo each, and was accused of being the financial backer of the infamous Captain Kidd. Cosby, another governor, was a convicted thief before the Lords of Trade sent him to New York, and the story of his rapacity and dishonesty, as told in the early history of the city, showed that he had not reformed. Sir Edmund Andros, of New York and New England, was grasping and unscrupulous, as well as a bully and tyrant. Sir William Berkeley of Virginia was a narrow-minded, 


\section{The Trhomen of Dioneer Daps}

domineering man, most cordially hated by the Colonists. He exacted a third of the gross returns from all traffic with the Indians, and then prohibited the Colonists from taking measures to protect themselves from depredations by the natives because it might interfere with the trade. Finally, the insolence and boldness of the Indians grew unbearable and there came an uprising, headed by Nathaniel Bacon, in which the Indians were so severely punished that they kept the peace for twenty years. For the action of the settlers, Berkeley hanged twentythree who had taken part. For this Charles II. signed his recall, saying: "This old fool has killed more people for a little mutiny in his naked country, than I did for the murder of my father." Governor Eden of North Carolina is said to have shared in the blood-gotten gains of the pirate Blackbeard. These were a few of the many appointees of the Crown who were a constant drawback to the progress and prosperity of the Colonies, if not a direct menace to the liberties of the people.

There were a few good governors like Sir Alexander Spottswood of Virginia, Col. Robert Johnson of South Carolina, and Governors 


\section{6 Dioneer Sinothers of Emerica}

Bellamont, Dongan, and Hunter of New York - men who in some degree foresaw the vast opportunities ahead of the Colonies and worked for their best interests and advancement. Yet even the ablest and best intentioned of the Crown's appointees were but creatures of the King and his Lords of Trade, bent upon beating down all tendencies toward republicanism and upon upholding the rights and authority of the English ruler.

Early in its history, each Colony came to have its own legislative body, in a general way fashioned after that little group that gathered in Jamestown in 1618 , which enacted such petty laws and ordinances as seemed necessary for the government and guidance of the people, but as the Crown controlled the naming of the upper house and retained the right to reject any law that did not meet the King's approbation, and as the execution of the laws lay largely in the hands of the governor, the Legislature was not calculated to give much relief, especially as the governor in most of the Colonies acted as a judge, sitting in the highest court, or controlling the appointment of such judges, and thus held two-thirds of the power of the Colony. In nearly 


\section{The ruomen of Dioneer Days}

all the Colonies, there was almost constant friction between the people and the governors, and as the governors represented the Crown and the Lords of Trade, ${ }^{4}$ there was a gradual lessening of the feeling of allegiance held by the people to the mother country.

Almost from the first, we find the Legislatures jealously guarding their charter rights which made them the sole power for raising funds by direct taxation, and holding always to their rights as English citizens to freedom from taxation, except with their own consent. Under one pretext or another, constant attempts were made during more than half a century to establish the right to impose such direct tax. Yet Parliament had never authorised it and only by direct requisition from the Crown, for quotas for the building of defences, or for the raising and maintenance of troops, were such taxes ever raised. In consequence there were always English politicians who schemed and planned to have the proprietaries made Crown provinces and take away their charter rights. But always there were enough far-seeing and fair-minded men in Parliament to oppose such action successfully, even though a majority in Parliament, and 


\section{$5^{8} \quad$ Pioncer SDotbers of America}

indeed many of the first lawyers of the realm, claimed the right of the mother country to tax her American Colonies, as they claimed her right to abrogate their charters at will. Yet always there was hesitation to press the issue, until at last the English shopkeepers dared to do more than her statesmen, and by them the Lords of Trade were driven to a series of acts of oppression so sordid and petty that they went farther towards driving the Colonies to revolt than would any scramble for appointive offices and legislative grants for their support.

Even as far back as the beginning of the eighteenth century, the mutterings of discontent were becoming ominous. For instance, in $\mathbf{I 7 0 2}$ the governors of the Colonies were instructed to declare war against France and a requisition was made of quotas "to build fortifications and to aid one another." "The other Colonies will not contribute till they are compelled by act of Parliament," wrote Cornbury, Governor of New York, who afterward urged "an act of Parliament for the establishment of a well-regulated militia everywhere." Virginia, upon this occasion, through her House of Burgesses, refused to do anything "that was disagreeable to a prejudiced 


\section{The Trlomen of Dioneer Daus}

people." The other Colonies fell into line with Virginia. "New York, the Jerseys, Pennsylvania, and the Carolinas," says the report to the home Government, "are but 'transcripts' of New England, which furnishes the worst of examples." In another letter, Cornbury wrote: "Till the proprieties are brought under the Queen's Government they will be detrimental to the other settlements." His Chief Justice wrote to the Secretary of State: "Anti-monarchal principles and malice to the Church of England increase in most proprietary governments, not omitting Boston; and to my own knowledge some of the leading men already begin to talk of shaking off their subjection to the Crown of England." It was Governor Nicholson of Virginia, who had held the same office in Maryland and in New York, who wrote in I698: "A great many people, especially those under proprietaries, and the two or three others of Connecticut and Rhode Island, think that no law of England ought to be in force or binding on them without their consent; for they foolishly say that they have no representative sent from themselves to the Parliament, and they look upon all laws made in England that 
put any restraint upon them, to be great hardships."

These questions, after all, much as they raised the ire of the politicians and the big merchants of Boston, New York, and Philadelphia, did not come down to the common people. But when it was enacted in 1699 that " no wool or manufacture made or mixed with wool, being the produce or manufacture of any of the English plantations in America, shall be loaden in any ship or vessel, upon any pretence whatsoever-nor loaden upon any horse or cart, or other carriage-to be carried out of the English plantations to any other of the said plantations, or to any other place whatsoever," it was carrying the oppression of a great and powerful Government to the homes of the humblest settlers. Sheep were raised in every Colony, and one of the sources of their scant income was made from the sale of the wool, woollen yarn, knitted hose, or the woven product. The act meant that no wool, woollen cloth, or woollen yarn could be sold in any other Colony nor sent to England for sale.

Many similar acts followed. America, the home of the beaver, could not manufacture 


\section{The Tulomen of Dioneer Daps}

hats for sale. No hatter could employ more than two apprentices; no American hats might even be sold from one plantation to another. With such restrictions, Americans could, of course, not come in competition with English hatters. Vast quantities of iron ore existed in most of the Colonies, but the English ironmongers secured the passage of laws practically prohibiting the smelting of iron. Ironworks were denounced as "common nuisances," and even William Pitt, friend of the Colonies as he was, declared that the Colonies had not the right to manufacture "even a horse-shoe nail," without the consent of Parliament. The shipbuilders of the Thames complained that the ship-builders of New England were destroying their trade, and a law was enacted that all goods destined for American markets must be carried in British-built and British-manned ships. That is, French silks or wines, West Indian sugar or molasses, or Holland-made goods, then generally used, must first be shipped to England and from there reshipped to American ports in British vessels. Fish imported from England was admitted to American ports, but fish carried from one Colony to another must pay duty. 
The effect of these laws was to increase greatly the cost of all imported articles to the Colonies, as well as to limit the market for their lumber, naval supplies, furs, tobacco, wheat, and codfish to Great Britain and thus vastly to curtail their income. The laws practically prohibiting the trade between the Colonies were especially burdensome and oppressive. The moneys collected as duties from this inter-colonial trade was for no needed revenue for the Government, but solely to curtail trade between the Colonies. Not a penny went to the Crown or Colonial treasury. One half the moneys collected as duties went to the collector, one fourth to the comptroller, and the other fourth was divided among minor officials.

These encroachments of the British Government did not all come at once but as constantly increasing aggressions stretched over many years. As they came to affect more closely the household, it was but natural that all the people, pioneer farmers on the frontier as well as the more forehanded in the older settlements, mechanics and labourers as well as the merchants and landed gentry, should come to an understanding of the matter in all its bearings, and 


\section{The Vullomen of Dioneer Daps}

that there should be "murmurings" of discontent in every Colony. Naturally, as the custom-house came to be recognised as one of the chief instruments of oppression, and the people came to realise that the one object of the collection of customs was to force them to trade only with English merchants and to restrain them from producing anything that would bring them into competition with English producers; that all this tariff was being levied solely to enrich one class of British subjects at the expense of another, smuggling became a common if not an honourable calling. There grew up a constant smuggling trade between the settlements along the Atlantic coast from Portsmouth to Savannah. Tobacco could be shipped lawfully only to English ports, but thousands of pounds were put aboard of Dutch ships by small vessels that ran out of the little creeks and inlets of Chesapeake Bay and the James River. There was a constant trade between New England and the West Indies. New England wanted West Indian sugar and molasses and other products, and the West Indies wanted whale oil, codfish, lumber, and other New England products. Coasting vessels from Philadelphia carried wheat and 


\section{Dioneer Sibothers of Elmerica}

ship-biscuit to the West Indies, and tar pitch and turpentine as well as other ship-building material were constantly carried from the Carolinas to West Indian ports. Consequently the custom-houses were eluded or defied or customs officials were bribed and trade thrived.

These were the conditions that were slowly but surely combining to break down the belief in kingcraft and all other self-constituted authority. This was the school in which the pioneer women, as well as men, were trained and developed, from that gold-mad settlement on the James, down to the Declaration of Independence, Cavaliers and adventurers, godly Puritans, stolid Dutch burghers, courtly French Huguenots, stubborn Scotch Presbyterians, English Catholics, and staid Quakers. How could they have been otherwise than a strong, sturdy, self-reliant, and courageous people, after all these years of fighting and guarding, struggling and triumphing? How could they have been otherwise than a serious, god-fearing, and liberty-loving people after all these years' experience of the breadth and depths of Divine Providence and the puny weakness and narrowness of men set in high places? How could the daughters of these 


\section{The Vulomen of Dioneer Maps}

dauntless, high-souled Colonial dames have been otherwise than the great-hearted, courageous, self-sacrificing, and patriotic women of ' 76 ?

Such further study as we shall make of the Colonies or Colonial times and conditions will be grouped about the lives of some of the women whose names are woven into the histories of the communities of which they were a part. Such life-stories must needs be scant of definite fact, of day and date. Our forefathers wasted little of time or ink in perpetuating the memories of their womenkind, and often the family Bible, wherein are recorded her birth, marriage, and death, and possibly the records of the Court of Probate, afford all the written information of the brief part she played. Household traditions, however, those confidences that come down from mother to daughter, give ample evidence of the important place she held as the head of her own family and the far-reaching influence she exerted in her narrow sphere of activity.

\section{NOTES TO CHAPTER I}

r The Grand Model was a form of government prepared by Lord Shaftesbury and John Locke for the Colonies, and attempted at the settlement on the Ashley River in South Carolina. It aimed to divide the wilderness into vast baronial estates, with hereditary titles and all the gaudy trappings of an ideal feudal aristocracy. The 


\section{Pioneer Sibothers of America}

people were too democratic in ideas to warrant its success, and the plan was abandoned.

2 An old record of the Salem court reads:

Io mo. I652, Alice, daughter of William fflint of Salem, presented for wearing silk hood. He was proven to be worth over $£_{200}$ and she was discharged.

29:4: I652, John Brackenbury of Salem, presented for wearing point and ribbands.

$30: 9: 1652$, Henry Bullocke of Salem, fined for excess in his apparel in boots, ribbands, gold and silver lace.

30:9: 1652, Richard Greene of Lynne, fined for wearing silver lace.

$30: 4: 1652$, John Tompkin's wife, fined for wearing silk hood.

3 William and Mary College, named after the reigning sovereigns, who gave a small sum of money towards its founding; the only college for which an English donation was made. Other colleges established before the Revolution were: Yale (I700), University of Pennsylvania (1749), Columbia (1754), Brown University (1764), Dartmouth (1769), and Rutgers (1770).

4 Lords of Trade, a board of commissioners for trade and plantations, established in $\mathbf{1 6 9 6 . ~ I t ~ w a s ~ c o m p o s e d ~ o f ~ t h i r t e e n ~ m e m b e r s , ~}$ appointed to "inquire into the means of making the Colonies most useful and beneficial to England; into the staples and manufactures which may be encouraged there, and the means of diverting them from trades which may prove prejudicial to England; to examine and weigh the acts of Assemblies; to set down the usefulness or mischief of them to the Crown, the kingdom, or to the plantations themselves; to require an account of all the money given to public uses by the Assemblies of the plantations, and how the same are employed." 


\section{POCAHONTAS}

WEARIED arm and broken sword

$W$ age in vain the desperate fight;

Round him press a countless horde,

He is but a single knight.

Hark! a cry of triumph shrill

Through the wilderness resounds,

As, with twenty bleeding wounds,

Sinks the warrior, fighting still.

Who will shield the fearless heart?

Who avert the murderous blade?

From the throng with sudden start

See, there springs an Indian maid.

Quick she stands before the knight:

"Loose the chain, unbind the ring!

I am daughter of the king,

And I claim the Indian right!"

Dauntlessly aside she flings

Lifted axe and thirsty knife,

Fondly to his heart she clings,

And her bosom guards his life!

In the woods of Powhatan,

Still ' $t$ is told by Indian fires

How a daughter of their sires

Saved a captive Englishman.-Thackeray. 



\section{Chapter II}

\section{Docabontas-Virginta}

Daughter of Powhatan, powerful Indian chief of Eastern Virginia, she was fast friend of first English settlers who went there in 1607-She is said to have saved the life of Captain John Smith, condemned to death by her father, and shown many evidences of a humane and gentle nature-The first woman of her race known to embrace Christianity-She was married to John Rolfe, a young planter who carried her to England, where she was well received by royalty and nobility-She died at the age of twentytwo, generally honoured and respected, leaving one son, through whom her blood is mingled with some of the best of the Old Dominion-Other of the first families.

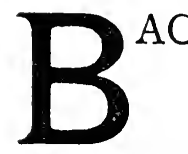

on the very threshold of American history there stands a slender, dusky figure, so wrapped about by the shadowy mists of tradition, that the outlines of her life-story must always be as hazy and uncertain as the shimmering summer light of the heat waves above the sand-dunes of her own Chesapeake coast.

For the figure we see is that of Pocahontas, the "Indian Princesse" of Virginia, the first of her race to marry an Englishman or to embrace his religious faith-the gentle and humane 


\section{Pioneer SMothers of Emerica}

"Metaoaca," whom from childhood we have been taught to revere as the saviour of Captain John Smith and of the little settlement at Jamestown.

There has upgrown among a certain class of writers a tendency to tear down whatever of tradition exists in the form of popular ideals. The daughter of Powhatan has not escaped. Her character and attributes, the incidents of her life, almost the very existence of the Indian maid, have been questioned by some of these iconoclasts. Of course, no one really doubts that she existed, but in the course of three centuries it is but natural that the certain facts of her brief but eventful life should have gathered about them some of the cobwebs of fiction. But to discredit the entire story of Pocahontas as a myth, because some of the fictions have by the uninformed been accepted as facts, argues a fatuous ignorance as lamentable as undue credulity. It was started some few years ago when a Cambridge professor discovered that Captain John Smith had not mentioned, in his True Relation of Virginia, how his life had been saved by an Indian maiden, when her father's warriors would have put him to death. "Since 

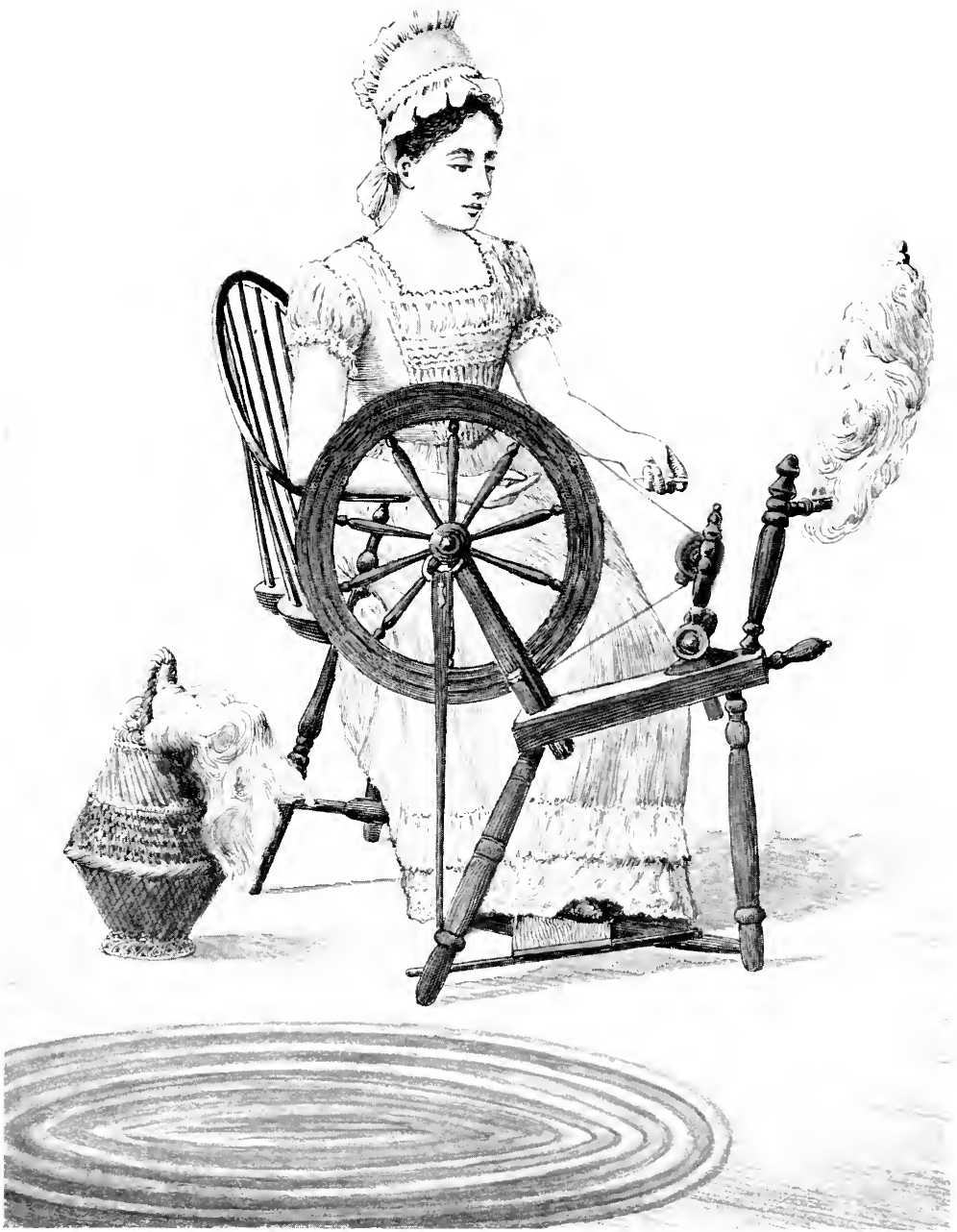

Spinning Flax.

Redrawn from an old print. 



\section{Docabontas-Virginia}

then," says a well-informed writer, "many American historians and scholars have concluded that it never happened at all, and in order to be consistent have tried to prove that Smith was a blustering braggadocio, which is the very last thing that in truth could be said of him. . . . The fact is, that nobody doubted the story in Smith's lifetime, and he had enemies enough." The doubting ones acknowledge the fact that Captain Smith, eight years after the publication of A True Relation, wrote to his Majesty, James I., excusing his friend Rolfe for marrying an Indian girl, in which he spoke of her as an "Indian Princesse," and continuing, said: "After some six weeks' fatting among those savage courtiers, at the minute of my execution she hazarded the beating out of her own brains to save mine; and not only that, but so prevailed with her father that I was safely conducted to Jamestown."

One of the most recent as well as one of the most trustworthy of Captain Smith's biographers, Mr. A. G. Bradley, explains this lapse of eight years on Smith's part in telling of the life-saving incident. "When he wrote A True Relation," he says, "it was important that intending settlers 


\section{Pioneer Mothers of America}

should not be frightened by any unnecessary tales of danger. . . . The editor in London, who published Smith's letter, distinctly states in a preface to it: 'Somewhat more was by him written which being (as I thought) more fit to be private, I would not advertise to make it publick.' Could it have been that the omitted part was the narrative which the worthy pioneer made public in later years?"

Pocahontas was one of the many children of Powhatan, the powerful chief of all the tribes of that portion of Eastern Virginia lying in the lower valleys of the James and York rivers. His own people were called Powhatans, and around their country were a number of other tribes, subject to Powhatan, and many of them ruled by a relative whom he had appointed, and all of whom paid tribute to him of all they produced, grain, tobacco, fruit, fish, furs, game, shells, dyestuffs, etc. Powhatan was an old man, sour of temper, cruel, crafty, and treacherous, if we may believe Captain Smith, William Strachey the historian, and others of the little band of Englishmen. To the early English chroniclers, the chiefs of the various Indian tribes with which they came in contact were 


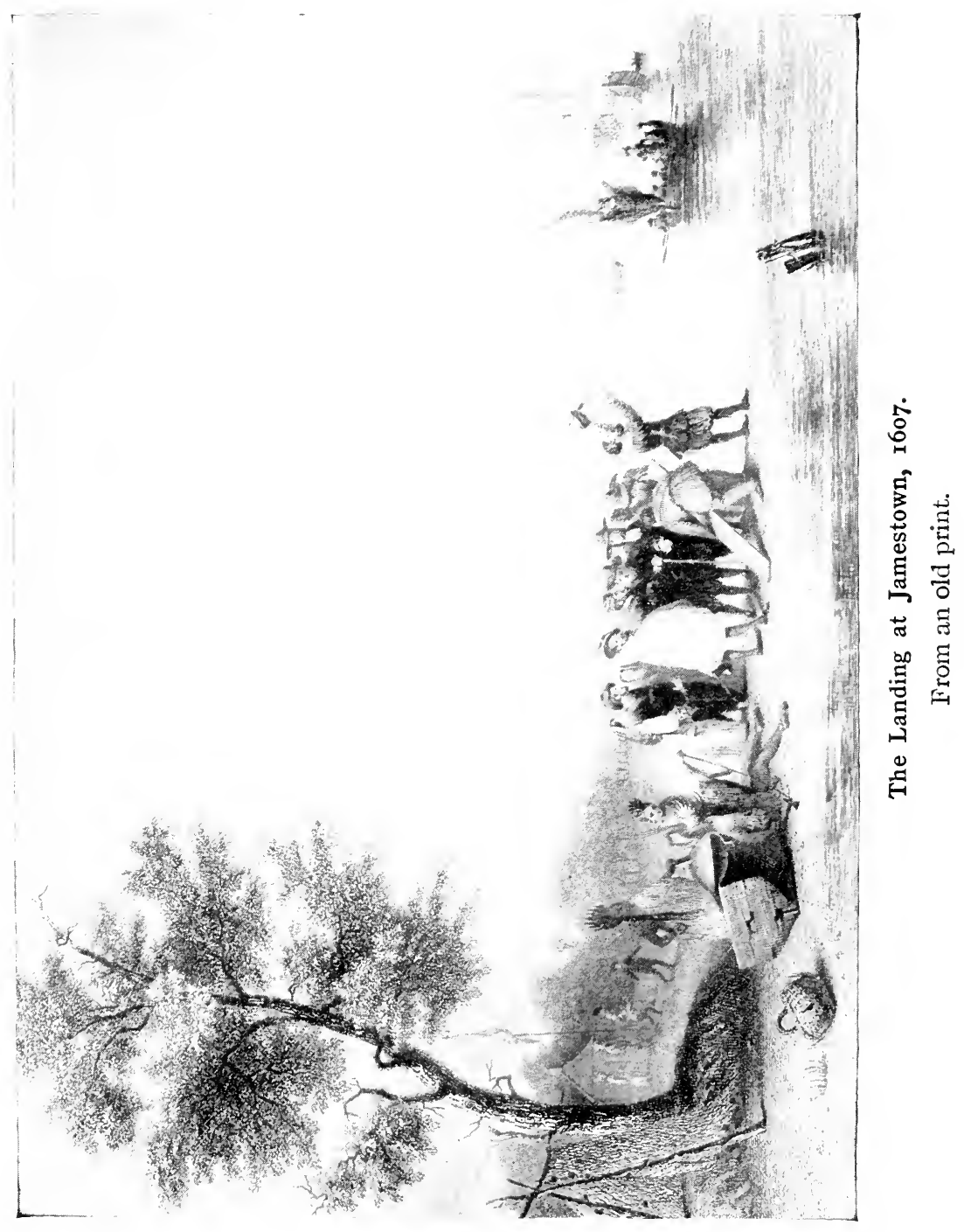





\section{Docabontas-Virginia}

always "kings," and "King" Powhatan seems to have been as powerful in the tidewater section of Virginia as was "King" Philip in bleaker New England.

Captain John Smith first saw the girl Pocahontas in the winter of 1607. Goaded by the London Council, whose servant he was, to find a supposititious passage through to the South Seas, he had started in a boat, with eight companions, to ascend the Chickahominy River. When they had reached a point about fifty miles up the river, Smith was led into ambush and captured. He was taken before "King" Opechancanough of the Pamawnkees, one of the tribes tributary to Powhatan. The Pamawnkee chief after a few days carried his captive, whom he treated with distinguished consideration, back, by a circuitous route, to Werowocomoco (now Shelly, Gloucester County), Powhatan's capital and residence, on the banks of the York River and only twelve miles from Jamestown. Powhatan was distrustful of the English and unfriendly, as he had shown on several occasions, yet he treated Smith with courtesy and fed him so well that the captive gathered the idea that he was being fattened 
for sacrifice, he having been assured that the Powhatans were not cannibals.

Early in January of that winter there was a great gathering at Werowocomoco: Opechancanough, Smith's captor and chief of the Pamawnkees, Opitchipan, Powhatan's brother and chief of another tributary tribe, Nantauquas, Powhatan's son, and several other chiefs and their retainers. It was a time for grave apprehension on the part of the captive, who had been in no wise deceived by Powhatan's half friendly attitude and studied courtesy. Powhatan's family at the time, as Captain Smith was able to observe, included his favourite wife, Winganuskie and his three daughters, Matchanna, Pocahontas, and Cleopatre. Matchanna was soon to be married to Tocomocomo, "a wise and knowing priest." Pocahontas, or as her father preferred to call her, Metaoaca, was a "small maiden of ten or eleven years and Cleopatre still younger." None of these young persons lived with her own mother. Powhatan rarely kept a wife after she had borne him a child, but gave her as a present to one of his chiefs.

Pocahontas was Powhatan's favourite child, 


\section{IDocabontas-Virginia}

and however sour-tempered, cruel, and vindictive he may have been, there can be no doubt of his affection for her. She is described as a slight, but well-built, little sprite, active, adventurous, and daring. "We read," writes Mrs. Pryor in The Birth of a Nation "among other adventures, of her attempting to swim across the Piankatank River, of her rescue from drowning by one of the Englishmen, and the consequent gift by Powhatan of Gwynne's Island to the colony; of the wild entertainment she devised and led for her friend, Captain Smith, all before she was a year older than at the time of which we are writing."

Captain John Smith was soon to find that his premonition of danger was not ill-founded; that all this ceremony was really because he was on trial for his life. He had been considered by his captor, Chief Opechancanough, too great a man to dispose of himself and so the wily old savage had brought his captive for trial to the court of Powhatan, his superior, who hated the English. Captain Smith in his News from Virginia, has told of this trial and the attempted execution. When the approach of the prisoner was announced, Powhatan put himself in position 


\section{0}

\section{Pioneer Mothers of Ammerica}

to receive him impressively. Forty or fifty of the tallest warriors were drawn up in two lines and between these the captive was taken. Inside the mat-lined council room the "King" reclined at ease on a couch or dais, about a foot above the floor and covered with mats. "He was hung with manie chaynes of great pearls about his neck, and covered with a great covering of raccoon skins and all the tayles'hanging by. On either hand did sit a young wench of sixteen or eighteen yeres, and along on each side the house two rows of men, and behind them as many women with all their heads and shoulders painted red, many of their heads bedecked with the white down of birds but every one with somthing; and a great chayne of white beads about their necks. Powhatan held himself with such a majesticall countenance as drave me into admiration to see such state in a naked salvage. $\mathrm{He}$ is of a personage, a tall, well proportioned man with sower looks. His head is somewhat grey, his beard is so thinne it seemeth none at all. His age is neare sixty (Strachey says eighty), of a very able and hardy body to endure any labour. This king will make his own robes, shooes, pots, bowes, and 
arrowes; and plant, hunt, or doe anything as well as the rest."

When the captive was led in, all the people cheered and shouted. The "Queen of Appamatuck" was ordered to bring him water to wash his hands, and another "queen" stood ready with a bunch of feathers to dry them. Platters of food, "deares meat, fish and fowle" were served, after which came the presentation of the charges of Opechancanough and his warriors against their prisoner, and we may be sure that there was much of vehement and denunciatory oratory, for it is likely that most of these Indians had more or less cause for grievance against the lawless adventurers of Jamestown, of whom Captain Smith was the chief.

While all this was going on and during the subsequent consultation of the chiefs with Powhatan, Captain Smith seems to have had ample time for observation, of which his journal shows he made good use. The little Pocahontas was there, big-eyed with admiration at the fierce-looking white man with the great mustachios, who had ever a kindly smile and a pleasant word for a child. John Esten Cooke, the Virginia historian, describes her dress on 
this occasion as being a "robe of doeskin, lined with down from the breast of the wood pigeon, with coral earrings, coral bracelets on wrists and ankles, and a white plume in her hair, the badge of royal blood." Mrs. Pryor, however, says: "But John Smith, who saw her face to face, has, in his picture of the scene which made her famous, presented her clad in her own charms and in these alone. Before the age of thirteen, the early historians tell us, Indian children wore no garments. ${ }^{x}$ Their mothers rubbed into their skins ointments which rendered them proof against 'certaine biting gnats such as the Greeks call scynipes, that swarm within the marshes'our snipe-like, long-billed mosquitoes, - and also against extremes of heat and cold. The paint pot could furnish the little maid with a new dress every day, if she desired it-red, white, or even black! I am afraid the little princess . . . fared like the rest of her people, unless the severe cold constrained her to encumber her active limbs with a "mantell of feathers.",

Finally, the consultation came to an end. Two attendants, acting on a signal from the "sower old man," brought in two great stones and placed them in an open space at one side 
of the room. Little Pocahontas knew only too well the dire meaning of these preparations and she implored her father to spare the prisoner. But the old man gave no sign, and the captive was dragged forth and his head laid upon the stones. Then it was, according to tradition, that the little maid sprang forward and, throwing her arms about the head of the doomed man, laid her own head on his. The great stone axe was already raised, but it did not fall. The grim executioner dared not strike. Who can tell the workings of the aboriginal mind? We only know that she was the favourite child and that Powhatan, cruel and vindictive as he has been pictured, was strong in his affections. Instead of ordering the child to be removed, he gave sign that the prisoner be spared, for the sake of the little maid, as he said himself, "to make her bells, beads, and copper."

Captain Smith was retained for some days as the guest of Powhatan, during which he played with the little girl who had saved his life, and matched wits with her crafty father, each trying to impress the other with the terrible power and strength of his fighting force. Then the Captain was allowed to return to Jamestown 


\section{Dioneer Mothers of America}

with presents befitting his importance. After that Pocahontas was a frequent visitor at Jamestown. "She came and went as freely to the fort as to her father's house, bringing corn and game or whatever she could get for Captain Smith."

Toward the end of the year 1608 , there came a great shortage of provisions in the little colony and the Indians showed a disposition to refuse to sell or barter their corn, until starvation stared the settlers in the face. Smith, upon invitation of Powhatan, paid the chief a visit at Werowocomoco, sailing around Point Comfort and up the York River, reaching his destination, January I2th. On the way Captain Smith was warned by a friendly chief: "Captaine Smith, you shall find Powhatan to use you kindly but trust him not; and be sure he have no opportunity to seize on your arms for he hath sent for you only to cut your throats."

Captain Smith was accompanied by a considerable force and care was taken never to be found without arms. For several days they exchanged complimentary untruths and presents and the English were fed plentifully and shown other courtesies. All the while Powhatan was 


\section{Docabontag-Virginia}

furthering his plan, which was to load the pinnace of the visitors with corn as a blind, then invite them to a series of merry entertainments, feasting and dancing, all to end in a great banquet at which every white man was to be massacred. "The eternall, all-seeing God did prevent Powhatan, and by a strang means," says the old chronicle. "For Pocahontas, his dearest jewell and daughter, in that darke night came through the irksome woods, and tolde our Captaine great cheare shoulde be sent by and bye; but that Powhatan and all the power he could make, would after come and kill us all, if they that brought it could not kill us with our own weapons when we were at supper. Therefore, if we would live, shee wished us presently to be gone.

"In requital for this information, our President would have given such things as she delighted in, but teares running downe her cheekes, she said she durst not be seene to have any; for if Powhatan should know it she were but dead; and so she ran away as she came."

Again, was the life of Captain John Smith saved by the Indian maid, and we may be sure that her welcome in Jamestown was none the 
less warm after that. She has been credited with bearing warning to the people of Jamestown upon another occasion when the Powhatans had made ready to surprise the town and massacre the inhabitants, but the weight of evidence seems to show that it was not Pocahontas but Chanco, an Indian boy who had been converted by the Rev. Mr. Hunt, the first minister of the little flock, who put the settlers on their guard.

In 1609, word came to Smith from London that he had been deposed as President of the Colony and was not even a member of the Council, and that a new charter had been granted, with Lord Delaware as Governor; Sir Thomas Gates as Lieutenant-Governor, and Sir George Somers as Admiral. After doing what he could to get the Colony in shape to leave, Captain Smith sailed back to England at Michaelmas in I609, leaving George Percy in command. He never again set foot on Virginia soil.

It was planned in London that LieutenantGovernor Gates, and Admiral Somers should go out to Virginia with a fleet of nine vessels, freighted with men and provisions, and that whichever of the two men reached the Colony first was to take command at once, superseding 


\section{Docabontas-Virginia}

the existing administration. The two men were so exceedingly jealous of each other that they agreed to make the passage on the same vessel and in May, I609, sailed from Plymouth in the good ship Sea Venture. Passengers in the same ship were John Rolfe, an English gentleman who was accompanied by his wife, William Strachey the historian, and two Indians, Namontack and Matchumps, a brother of Powhatan's favourite wife, Winganuskie, all of whom were to come into the life-story of the little Pocahontas. The ship became separated from the others of the fleet and after much buffeting of storm and wind was wrecked on the Bermudas, where Admiral Somers and the Lieutenant-Governor, each set at work to build a new vessel. During the stay on the island, Mistress John Rolfe gave birth to twins, a boy and a girl, who were given the names, Bermudas and Bermuda, respectively.

Seven vessels of the fleet reached Virginia in August, I609, shattered by storm, and having lost most of their supplies. The men they brought were a sick and shiftless lot and by May, I6Io, the little settlement was in a most deplorable condition. "The earth was trampled 


\section{8}

\section{[Pioneer SDothers of Emerica}

bare of all verdure, ragged stumps of the felled trees were rotting in the ground, noisome vapours rose from the neglected filthy yards of a pestilence-smitten town. Men, women, and children, gaunt and wild-eyed from famine, perishing by inches slowly but surely, lay about the town moaning and despairing. They knew that without help they could not survive many hours."

It was at this point of time that two vessels appeared on the river. They were the two ships that Admiral Somers and Lieutenant-Governor Gates had built on Bermuda. Gates and Somers reckoned up their supplies and calculated that they had enough to last sixteen days, and they at once concluded to abandon Jamestown and with all the colonists sail for England, via Newfoundland, where English fishing vessels might be found to supply them for the voyage home to England. The poor colonists were overjoyed. The fort was at once dismantled and the cannon buried at the bottom of the gates. But for the second thought of the commanders, the houses and cabins, which they were about to desert, would have been burned. There were only about sixty of them left out of the five hundred and more, that John Smith had left 


\section{Docabontas-Virginia}

behind when he sailed away only a few short months before.

So bid fair to end the English settlement at Jamestown. The little fleet with the wasted and disheartened colonists dropped down the bay as far as Mulberry Island, where they were met by Captain Edward Brewster in a rowboat, hastening to intercept them. Lord Delaware had arrived at Point Comfort with three vessels laden with provisions and all things needful, and, hearing from Captain George Percy, who was there at the little fort lying sick, of the movements of Somers and Gates, had sent to command their return. Back they went, most of the colonists being grievously disappointed at the prospect.

But what of the little Princess Pocahontas all this time? ${ }^{2}$ After the return of Captain Smith to England, early the previous year, she had not been seen by the Jamestown colonists. Kemps, a friendly Indian much about the fort, and Matchumps who was also friendly to the whites, said that she had been married to a "Captaine named Kocoun," who was dead. In I6I2, Sir Thomas Dale, the Governor who had succeeded Lord Delaware, sent Captain Argall 


\section{0 \\ Pioneer Mothers of America}

to the Potomac to trade for corn. He became friendly with Japizaws, a chief, and learned from him that Pocahontas was visiting his wife. On board Argall's vessel was a large and gorgeous brass kettle which Japizaws greatly fancied, and Argall conceived the idea of kidnapping the Indian girl and holding her for ransom in corn by her father, Powhatan. She was inveigled on board by her friends and while she was being shown over the ship, they took their brass kettle and made their escape. She is said to have wept bitterly when she found that she had been betrayed, but was somewhat comforted when she found that she was to be taken to Jamestown.

Powhatan was greatly enraged, when he was approached in regard to the ransom, but, knowing that no harm was likely to befall his daughter in Jamestown, bickered and bargained for several months. In the meantime, Pocahontas, now a comely girl of sixteen or seventeen, had found favour in the eyes of Sir Thomas Dale, "a man of good conscience and knowledge in divinitie," and he ordered that she should be educated and taught the Christian faith. Her instruction, religious and secular, was left to the Rev. Mr. 


\section{Docabontas-Virginia}

Whittaker, who found her an apt and ready student and that the seeds of an education had already been planted by the good Rev. Thomas Hunt, his predecessor. The maid spoke English, though imperfectly. Every one in Jamestown knew of her early devotion to Captain Smith and the starving colonists, of how she had saved the life of the boy Henry Spelman and of another Englishman, and she was honoured and respected accordingly, especially by the newcomers to whom the redman was a rarely interesting novelty. Among those who became interested in the Indian girl was John Rolfe, whom we met many months ago as he took passage for Virginia on the Sea Venture. Since then he had lost his wife and infant daughter. Rolfe is a man of some prominence in the settlement, destined to become Secretary and RecorderGeneral of the province, as well as wealthy from tobacco planting. He is a "godly man," according to the testimony left behind, and from the letter which he wrote Sir Thomas Dale, asking permission to pay his addresses to Pocahontas, must have been very much in earnest in his courting. However, Sir Thomas gave his consent, clearly foreseeing that such a marriage 
would do much to end the war between the settlers and Indians, and she became the fiancée of the love-lorn young planter. Captain Argall then took her to York to make another appeal to Powhatan. When the engagement was announced, the old King was delighted, but, not proposing to be forced into paying her ransom, now that she was about to have a husband, declined to see her or Captain Argall. However, when they returned to Jamestown they found Opachisco, Pocahontas's uncle, and her two brothers there, to attend her wedding, and bearing a finely dressed deerskin, a wedding gift from her father. This was in $16 \mathrm{I}_{3}$, and Pocahontas had already been baptised in the little church, which Lord Delaware had rebuilt and beautified, upon which occasion she had been given the name of "Rebecca." The marriage seems to have been a happy one, as the chronicles tell us that John Rolfe and his dusky bride dwelt "civally and lovingly together" at "Varina," which was her place of residence as long as she remained in Virginia.

Pocahontas seems to have lived a quiet life here, on her husband's tobacco plantation, until she visited England with her husband in 


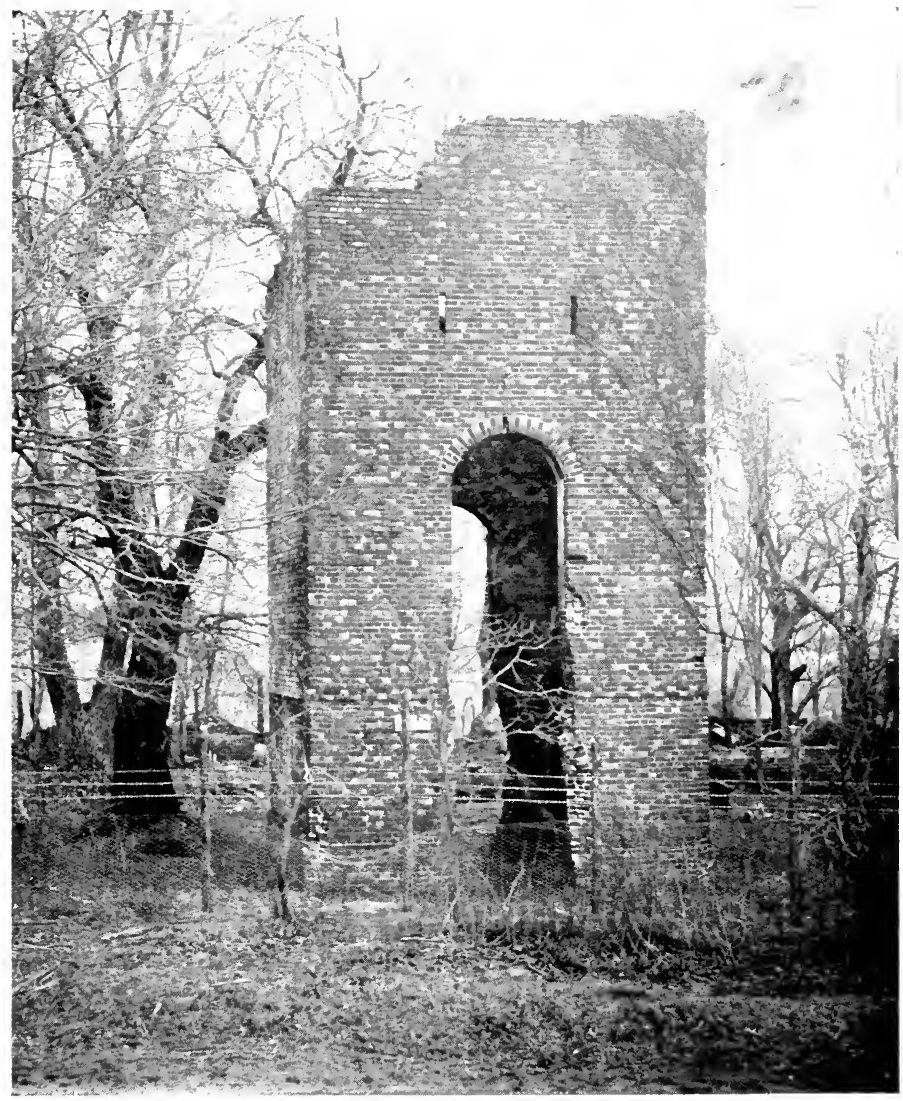

Tower of the Old Church at Jamestown, Virginia, in which Pocahontas was Married. 



\section{Docabontas-Uirginia}

I6I6. Captain Smith heard of her presence there and wrote a letter to Queen Anne, relating in detail the story of her goodness to him and of the service she had rendered, child as she was, to the settlers, and beseeching the kindness of the Queen for the "Indian Princesse," who, though forest-born, was of "Royall blood." Almost immediately Pocahontas became a social sensation. She was well received at Court. Many of the nobility and the church dignitaries entertained her, and always she conducted herself with the grave dignity and propriety of manner that reflected credit on Lord and Lady Delaware who were her sponsors. There was born to her a son while she was in England, and the London Company made provision for him. It would be interesting to know the secret thoughts of John Rolfe, who had apologised to Governor Dale for desiring marriage with her as "her education hath been rude, her manners barbarous, her generation accursed," and here was addle-brained King James seriously inquiring if he should not mete punishment to him, a commoner, for "marrying this,

a princess, without his consent."

But soon the damp fog of London began to 


\section{Dioncer SilDotbers of Emerica}

undermine her health, which the miasma of the Jamestown marshes had never done, and John Rolfe took a cottage at Brentford. There it was that John Smith visited her. From fear of offending the King, he addressed her as "Lady Rebekah," which wounded her so deeply that "she turned away, refusing to speak." After a time she reproached him for his distant manner and reminded him that he had always called Powhatan "father," and so she now meant to call him, and be his "child, and for ever and ever his countrywoman."

Pocahontas was on her way home when she was taken sick off Gravesend and was carried ashore to die March I, I6I7. She was buried in the chancel of St. George's Church. In the present church, which was built on the site of the old one, there has been erected a marble tablet, the gift of the pastor, Rev. H. Haslam, in commemoration of the gentle Indian maiden. A beautiful stained glass window, commemorative of the life of Pocahontas, was the gift of the same clergyman. Many Americans visit the quaint old church every year, and the name of Pocahontas is held in almost as loving remembrance as in Virginia itself. 


\section{Docabontas-Wirginia}

Thomas Rolfe, the son of Pocahontas, was educated partly by Sir Lewis Stukely but mainly by his uncle Henry Rolfe, and, grown to manhood, returned to Virginia, where he became a man of prominence and substance, ${ }^{3}$ as the old writers have it. He married a young lady of England, and his descendants were married into the families of Bolling, Randolph, ${ }^{4}$ Gay, Eldridge, Hemmings, and Murray, among the best-known blood of the commonwealth.

The marriage of Pocahontas to John Rolfe, at Jamestown in 1613 , was not the first wedding in that miasmatic "cradle of a nation." While yet the "Indian Princesse" was but a mischievous little girl romping about the streets of the settlement, so nearly in a state of nature as to shock the sensibilities of the grave historian, Strachey, though she was the "Deare and Darling Pocahontas" to all the rest of the Colony, Ann Burras, who came over in October, 1608 , and was married the following December, was the first English woman to be married in America. And her daughter, born less than a year afterward, was, after Virginia Dare, the first English child born in the New World.

Ann Burras or "Anne Burroughs," as some of 


\section{$98 \quad$ Dioneer Smothers of America}

the later historians write it, was a maid in the service of Mrs. Thomas Forrest, who had accompanied her husband on a visit to the new and strange land. Ann was but fourteen years old, a healthy, handsome country-bred girl, sister of John Burras, tradesman, who came out on the same vessel to join the Colony, As they were absolutely the first women to come to Jamestown, it was not surprising that before Christmas she was wed to John Laydon, a carpenter of the Colony.

Of the coming of Ann Burras, we can do no better than borrow the pretty story told by Mrs. Pryor in her Birth of a Nation, with only the regret that this indefatigable delver into the bygone traditions and annals of her State should not have written more:

"And now in October an unexpected ship appears on the broad bosom of the James. The London Company has hurriedly fitted out the Mary and Margaret, and sent Captain Newport back to hasten Smith's discovery of the northward passage to the South Sea. As the ship approaches, the keen eyes of the crowd on shore discern something besides the red cross of St. George fluttering in the autumn breeze. What 


\section{Docabontas-Virginia}

means this white pennon, like a flag of truce? The amazed watchers rub their eyes and gaze again. 'It looks like-but no, that cannot beit certainly looks like-yes, it is-an apron!'

"Sure enough on the forward deck a small slip of a maiden stands beside a matron in ruff and farthingale, and the little maid's apron signals a greeting to the shore. This is little fourteen year-old Ann Burras. Her brother, 'John Burras, Tradesman,' is on board. She is going to be a famous woman very soon, young as she is. She is going to marry John Laydon, and hers will be the first marriage, and her little daughter will be the first English child born in Virginia, and the London Company will be proud of her and look to her dower, and she and her John will found the genuine 'first family' in Virginia. She is very unconscious of all this as she stands in her ruff and short petticoat beside her mistress, Madame Forrest, who is brave in a farthingale, long-pointed bodice, lace ruff, and broad-banded hat. Her husband, "Thomas Forrest, Gentleman,' is on board, but the 'Gentleman' and his Madame signify very little beside the rosy English maiden who serves them.

"All hands were called in from the forest and 


\section{Ioo Dioneer Silotbers of Almerica}

the kettles early in December," she writes later, "to attend the first English marriage in Virginia. Of course, pretty Ann Burras found many admirers in a colony of two hundred and equally, of course, she could accept but one. Her bridegroom, John Laydon, Carpenter, was twentyseven. The ceremony was performed in the church by good Master Hunt, who was soon to be called to the reward of a noble Christian life. . . . It is probable that Pocahontas was present. She was known to all as 'Deare and Darling Pocahontas,' and when a wedding was to the fore we may be sure she was apprised of it.

"Little Ann Burras brought good fortune to her honest carpenter. More than once they were given land in Virginia, at one time as much as five hundred acres. She bore many children. There was a Catharine, an Alice, and a Margaret; but the first child was named 'Virginia.' The family lived long, and survived all the hard times - the starvation, the sickness, and the great massacre of I622."

Records show that they were still living, at Elizabeth City, in 1632. In the Sea Venture which sailed for Jamestown - the same ship that carried Sir Thomas Gates and his wife 
and children and John Rolfe and his wifethere came the Reverend Richard Buck and his wife, William Pearce, whose wife and child were to follow him when he had established a home, and George Yeardley, who was to be knighted for his labours in the new Colony. The Sea Venture, which, as has been told, was wrecked on the Bermudas, did not reach Jamestown until r6ro. Yeardley found a wife waiting for him, a young woman who had come over in I609. Not much is known of her save that her name was Temperance and that her father died of the voyage. Their wooing was evidently a short one as they were married by the Reverend Richard Buck early in I6I I, and their first child, Elizabeth, was born within a year. The wife and little daughter of William Pearce, arrived in 1609 also. This little maid was destined to become the third wife of John Rolfe in I6I 8, and take the place at his hearthstone, on his tobacco plantation at Henricus, left vacant by the untimely death of the gentle Pocahontas. The wife of Sir Thomas Gates died before the Sea Venture reached Virginia, and their two little daughters were sent back to England to be educated. Besides their daughter Elizabeth, 
there were born to Sir George Yeardley and his wife Temperance two boys, Argall and Francis. Three children were also born to the Bucks, and soon the little Yeardleys and Buckses and Burrases began to gladden by their happy presence the grim stockade that had been witness of so much of hardships and suffering. Descendants of all three of the families are to be found scattered through the history of the Colony and State.

The first ship that came over in 1607 had among its passengers a boy, Thomas Savage, whom the colonists placed in the hands of Powhatan as a hostage, taking in return Powhatan's nephew, Namontock, who was sent to England as one of the exhibits to the London Company. Savage was a bright and friendly boy who seems to have become a favourite with the Indians. He learned their language and many times afterward served as an interpreter. He married an English girl in 1620 and his descendants were prominent in Colonial life. This girl was probably one of the one thousand colonists sent over that year by Sir Edwin Sandys, which consignment included the first of the "bride emigration" 5 - ninety of the two hundred, the 


\section{Docabontas-Virginia}

marriageable maidens, sent out by the London Company, which had come to see that permanent settlements without real homes and wives and families could not be established.

In that year and the two following there came 3000 settlers into Virginia,-too many in fact for the small amount of land that the colonists had cleared and a lack of labour to furnish provision enough for all, even when eked out by the inadequate and unsuitable supplies which the immigrants brought with them. Many of the settlers went back to England, and many more came to their death from disease induced by the climate and the miasmatic conditions about Jamestown. Those who remained and became acclimated were of good stock, ambitious and industrious, and the Colony prospered. In I620, 40,000 pounds of tobacco were sent back to England. There came a terrible setback in I622, the worst Indian massacre the Colony ever knew. Powhatan, the old chief who, from the marriage of Pocahontas, his daughter, to John Rolfe, had been a friend to the whites, was dead, and Opechancanough, who was their implacable enemy, was his successor. Opechancanough was far-sighted enough to see that unless the 


\section{I04 Dioncer SMothers of Elmerica}

white men were driven out of the country the Indians would be; and so had plotted and worked for years to bring about a general uprising. It was ably planned and so well carried out, that but for two or three Indians who had experienced marked kindnesses from some of the settlers and warned them at the last minute, there would have been scarcely an Englishman left in Virginia. At exactly the same hour on the same day, March 2Ist, the savages fell upon Jamestown and each of the little settlements around it with the utmost ferocity. Deceived by the apparent submissiveness of the Indians, the settlers were almost entirely off their guard. Three hundred and forty-seven were killed, men, women, and children. The settlers soon rallied and began relentless war upon the Indians, driving them from village to village, killing and burning without mercy, until they secured a peace that lasted more than a score of years.

For the next few years, the affairs of the little settlement moved with smoothness and prosperity. When Lord Southampton had said, back in I6I6, "The hopeful company will provide estates for all younger brothers, gentlemen of this kingdom," he had spoken as a prophet. 


\section{[pocabontas-Virginia}

Among the settlers who came pouring in were not only skilled labourers, farmers, and tradesmen, but many gentlemen, younger sons and their kind, with means to establish plantations and stock them so that they would be productive almost from the first. Mostly they were Church of England people, accepting that form of worship as a matter of course, but not troubling themselves over-much about religious matters. Of course these people, loyal Englishmen, as they were, sympathised with the King during the progress of the civil wars, and denounced in their Legislature as an act of treason the death of Charles I., and resolved that it was the right of Charles II. to be King of Virginia "and all the other of His Majesty's dominions and countries." Really, however, while mourning the dead King they were to profit greatly from the Protectorate. The people in Puritan New England, while sympathising with the Puritan element in England which had brought this about, and exalted in spirit by the downfall of Archbishop Laud and their other enemies, had come to see that it was a sad blow to their prosperity, as it put an end, for the time being, to immigration and the consequent ready market for their lands 


\section{Io6 Dioneer SDothers of Emerica}

and surplus products. The contrary was the case in Virginia. Partisans of the King at home looked upon Virginia as their safest place of refuge, and her open country began to fill up with exiled Cavaliers. Thus Virginia grew in population and wealth while Massachusetts and Connecticut stood still.

It was largely in this period and the two or three decades following that in Virginia was to be built up that great body of landed gentry that for a century and more was to make the Old Dominion one of the foremost of the Colonies. This stream of immigration did not stop with the Restoration. The provinces still continued to draw many Cavalier families. In I648, there were I 5,000 English people in Virginia, and in 1670 there were 38,000 , and nine new counties sent Burgesses to the Assembly. All the broad tidewater country to the northward of the original settlements on the James, clear to the Potomac, was beginning to fill. It was during this period that there came such men as Col. Richard Lee, of the ancient family of Coton Hall, Shropshire, John Washington, grandson of Lawrence Washton of Sulgrave, and cousin of Col. Henry Washington who stormed Bristol with Prince 


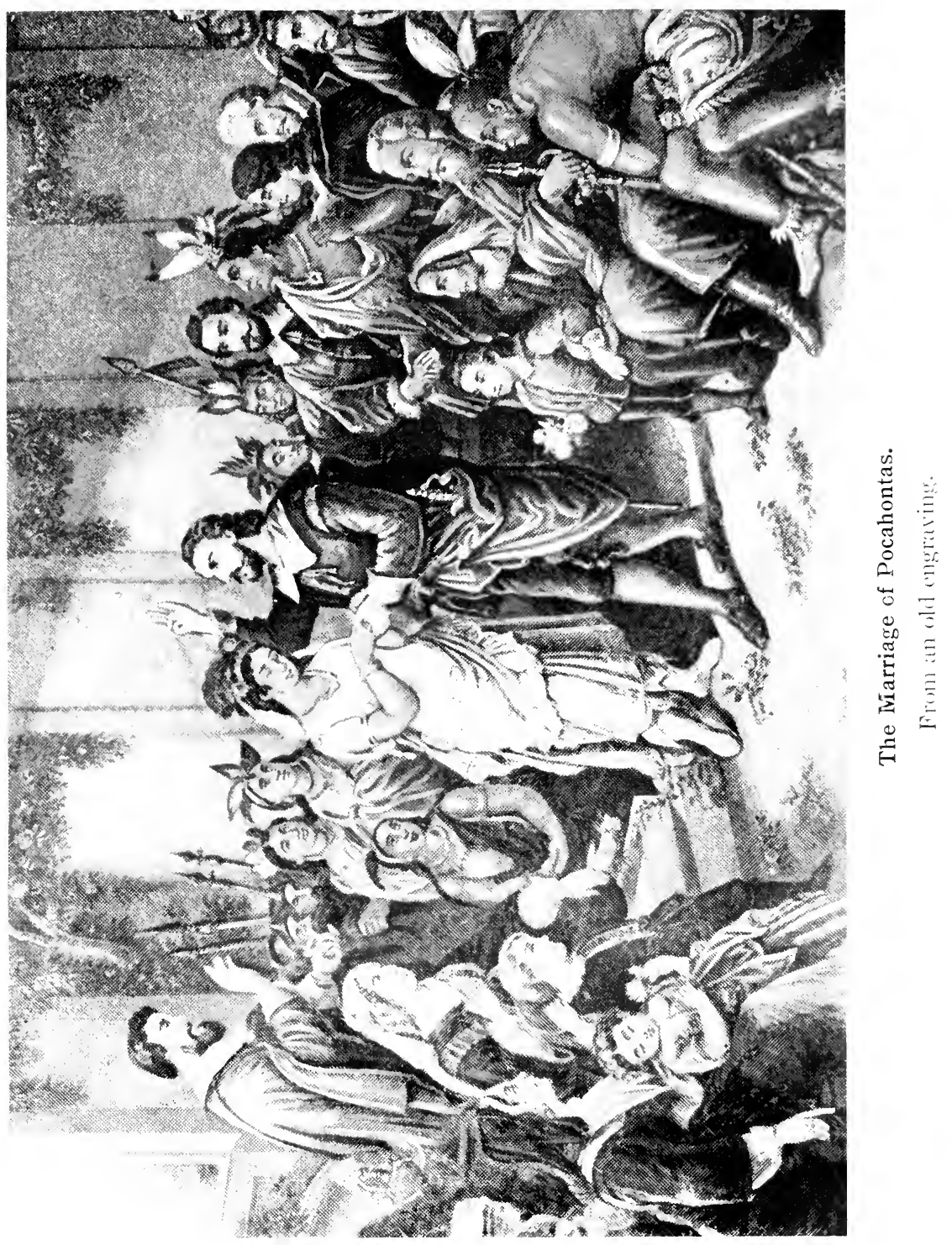





\section{Docabontas-Virginia}

Rupert, the Pendletons, the Randolphs, the Madisons, the Marshalls, the Parkes, the Ludwells, and the Careys and many others whose names loom large in the subsequent history of the Colony or the commonwealth. Naturally society was enriched by the addition of so many families of culture and education, but these men and women, who had shone at Court and graced the drawing-rooms of aristocratic England, were in a few years to be transformed into thoroughgoing Americans, republican at heart, as were the Winthrops and Winslows and Endicotts of Massachusetts, or the Van Rensselaers and Schuylers and Livingstons of New York.

\section{NOTES TO CHAPTER II.}

'Strachey, "our learned, reliable historian," in describing the dress of Indian maids and matrons, says that girls before twelve wore no clothing at all in summer. He says further: "The before mentioned Pocahontas, a well featured, but wanton younge girle, Powhatan's daughter, sometime resorting to our forte, of the age then of eleven or twelve years; would get the boyes fourth with her to the market place, and make them wheele, falling on their hands, turning their heeles upward; whom she would follow and wheele soe herself, naked as she was, all the fort over."

2During that winter of starvation, one of the journals kept by the adventurers has this entry: "DEARE and BLESSED Pocahontas, who of her own good heart, ever once in four or five dayes appeared at the gate of the palisades with a wild traine of Indians behinde her, bending down under baskets of corn and venison which saved many of their lives that else had starved from hunger."

3 As "Lieutenant Rolfe" we find him in command of Fort James 


\section{Io Dionecr Mothers of Elmerica}

on the Chickahominy, and later, I6+1, we find his petition to the governor for leave to visit his grand-uncle Opechancanough and his aunt Cleopatre, both of whom seem to have been living in the woods on the York River.

" One of his descendants, says Cooke, "was John Randolph of Roanoke, who was proud of his Indian blood. His manner of walking and the peculiar brightness of his eyes are said to have betrayed his origin, and he once said that he came of a race that never forgot or forgave an injury. He was sixth in descent from Pocahontas, through Jane Rolfe, her granddaughter.

$s$ This was a favourite scheme of Sir Edwin Sandys. To prevent all objection, the purity of the feminine supply was jealously guarded, and two of the number who transgressed were sent back to England. Every safeguard was thrown around them to make them happy in their new homes. It was ordered: "In case they cannot be presently married, we desire that they may be put with several householders that have wives until they can be supplied with husbands. . . . We desire that the marriage be free, according to nature, and we would not have these maids deceived nor married to servants, but only to freemen or tenants as have means to maintain them . . . not enforcing them to marry against their wills."-CookB. 


\section{THE MAYFLOWER}

DWN in the bleak December bay
The ghostly vessel stands anday:

Her spars and halyards white with ice, Under the dark December skies.

$A$ hundred souls, in company,

Have left the vessel pensively,-

Have reached the frosty desert there, And touched it with the knees of prayer.

And now the day begins to dip,

The night begins to lower

Over the bay, and over the ship

"Mayflower."

The Canaan of their wilderness

$A$ boundless empire of success;

And seen the years of future nights

Jewelled with myriad household lights;

And seen the honey fill the hive;

And seen a thousand ships arrive;

And heard the wheels of travel go;

It would have cheered a thought of woe,

When now the day began to dip,

The night began to lower

Over the bay, and over the ship

"Mayflower."

Wolcott Ellsworth. 



\section{Chapter III}

\section{Driscilla Mullins of Dlymoutb}

The maiden of the Mayflower, made famous by the storied romance of her wooing by John Alden, who has come to stand typical of the Puritan young womanhood of New England-Susanna White, Mary Brewster, Elizabeth Hopkins, and Helen Billington, the four Pilgrim mothers who lived through the awful "first winter"-Mary Chilton, the first woman whose foot touched Plymouth Rock-Alice Southworth Bradford and other mothers of the first families of Massachusetts-Story of the coming of the Pilgrims and the founding of Plymouth Colony.

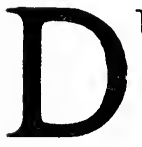

URING the long years since the mooring of the Mayflower in Cape Cod Bay, much of the romance of the Plymouth Colony ${ }^{\mathrm{I}}$ has come to be centred around the name of "Priscilla the Puritan maiden," as the glory of Puritan motherhood clings about the names of Susanna White Winslow, Mary Brewster, Elizabeth Hopkins, and Alice Southworth Bradford.

Romance is the handmaid of history; often in the making, always in the effective telling. For the mind is ever prone to grasp and retain the facts that bring a responsive heart throb- 


\section{4 Dioneer SDotbers of Elmerica}

that go to make human the lay figures around which historical events are draped. So it was that the storied courtship of the shy and lonely orphan Priscilla, by the "fair-haired and taciturn" John Alden, has made her the most popular, if not the most famous, of the Mayflower women-a distinction that she hardly deserves amiable and admirable as undoubtedly her character was. There were at least three other women on that scurvy-laden vessel whose names were destined to preservation by descendants equally illustrious in the annals of Church or State as those of Priscilla Alden.

Of the eighteen wives and mothers who cared for and comforted their dear ones in the confined cabin of the Mayflower, fourteen were doomed to death within a few months of the time they sighted Plymouth Rock. This awful destruction of the wives and mothers is a fact worthy of consideration. We know that it was love that led these devoted women to brave the perils of the long voyage and life in the wilderness. How far was it the direct cause of their succumbing to the cold, hunger, and other privations they were forced to meet? Did they sacrifice themselves for their husbands and children? 


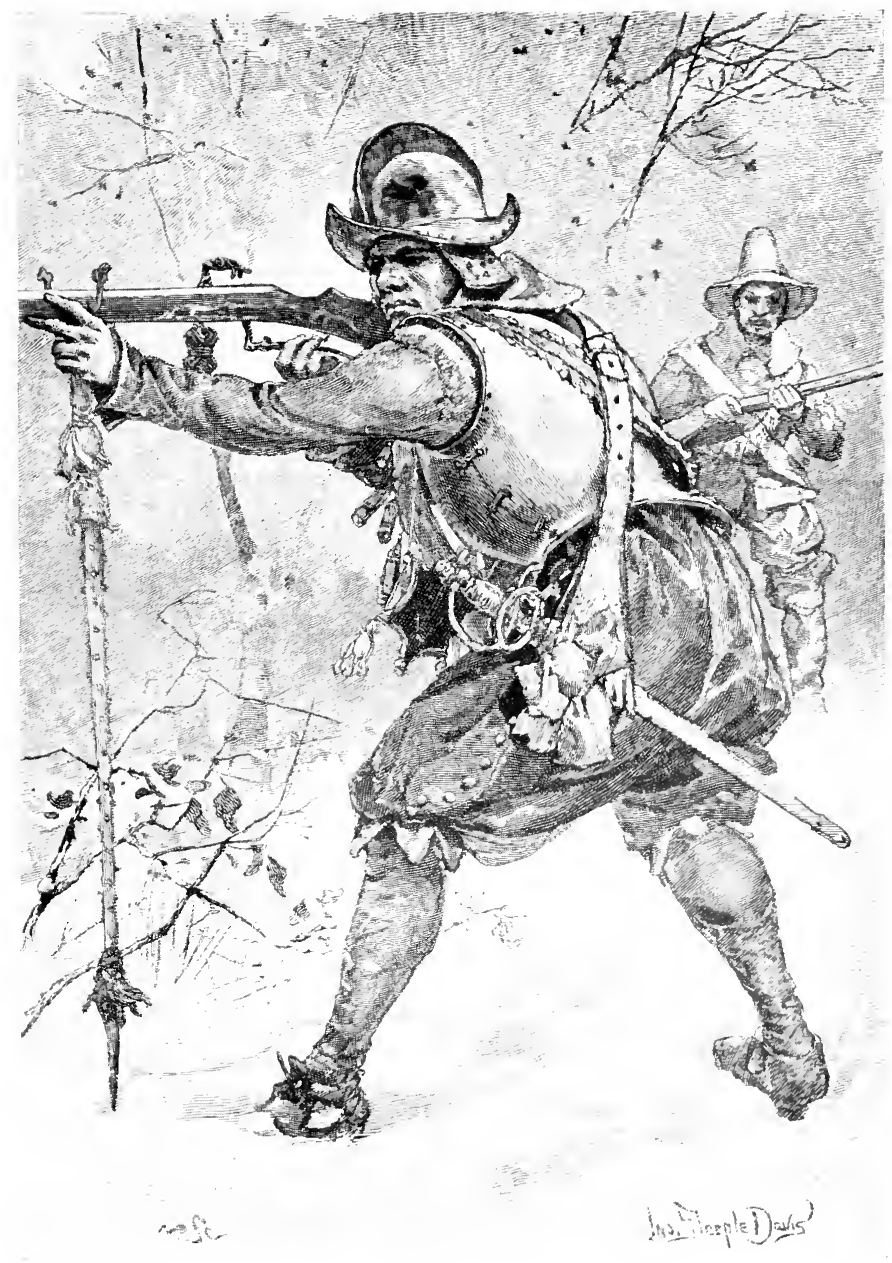

Armour Worn by the Pilgrims in 1620 . 



\section{retomen of the sliaptlower}

We can only conjecture as we study the mute records which show that none of the daughters that came on the Mayflower died, and but three of the sons, and they were of families in which the parents were also taken.

Of these fourteen there is necessarily very little known. That they were of Pastor Robinson's congregation of refugees at Leyden; that some of them were married there; that all of them were of English parentage, if not of English birth; that they willingly followed their husbands when the emigration to the New Land was decided upon, and that they died in the faith, is set down in the records; but the stories of their innermost lives, their wrestlings with the spirit, their mental and physical trials and temptations and triumphs must remain forever a closed book. Four families were completely obliterated in that "first sickness," so that even their names do not further appear in the records.

Priscilla the Puritan maiden, immortalised by Longfellow's Courtship of Miles Standish, was the sixteen-year-old daughter of Alice and William Mullins, who, with an older son, Joseph, and Robert Carter, a man servant, came over on the Mayflower. This family had gone to 


\section{i 8 Dioncer Smotbers of America}

Leyden from England, and there seems to be no valid reason to suppose that they belonged to other than the sturdy English stock that the name indicates, though attempts have been made to show that they came from the old Huguenot family of Molyneaux and that the name had been corrupted into "Molines." Some authority for the latter may be found in the spelling of the name by Bradford, the chronicler of Plymouth Colony, but as Bradford was apt to spell phonetically the evidence is not conclusive. But neither the historians nor the genealogists of the family have been able to find much more than that they were a part of Pastor Robinson's flock at Leyden and had come to America with it, and that William Mullins "was a man, pious and well deserved, endowed also with a considerable outward estate."

Of the life of the women and children on that floating bethel during the nine long weeks' voyage across the Atlantic, we have little record. We know that it was not a monotonous voyage, nor unpleasant until they reached mid-ocean; when they ran into a gale and the ship was strained so badly that one of the beams amid- 


\section{Tramen of the sinauflower}

ship was bowed and cracked; but fortunately one of the passengers had brought with him from Holland "a great iron screw," probably a jack-screw, by which the dislocated beam was raised to place and a post set in under it, after which the hull was again made safe and seaworthy. The upper decks were calked, thus keeping out the greater part of the waves which washed over them, but there was still enough coming down the hatchways to keep the wretched passengers wet and cold in stormy weather. And there were storms, when for days they were forced to "scud along under bare poles," while the company were kept below decks, shivering, sea-sick, and forlorn, and in the foul air breeding the germs of quick consumption that was to bring so many of them to an early death. It was in one of these storms that young John Howland, coming up through the hatches, was, by a sudden pitch of the boat, thrown overboard, "sinking sundry fathoms under water," as Bradford puts it. He was fished out with a boat-hook and saved to become an important and valuable member of the community. William Button, an assistant to Samuel Fuller the surgeon, died on November I6th, but this loss in numbers was 


\section{20 \\ Pioneer Mothers of America}

made up by the birth of the baby boy, Oceanus, born to Stephen and Elizabeth Hopkins, who, with the baby Peregrine White, born some days later, made the total register of the Mayflower one hundred and four, seventy-seven males and twenty-seven females. Of these seventy-seven men, forty-one signed the famous compact - "that noble framework of government, simple but efficient," the other males being minors or servants.

Of the impressions of the little Pilgrim maid, as the Mayflower was driven to anchor near the "dangerous shouls and roring breakers" inside of Cape Cod, we know nothing. Happy she must have been of course at the approaching end of the long dreary nine weeks' voyage; and devoutly thankful as became her faith and training, though it is not likely that she voiced her feelings to any one, save perhaps her mother, as it was not seemly that a girl should be heard in public places nor among her elders. It would be interesting to know what this wideeyed maid secretly thought of these same elders, of the grave and gentle Ruling Elder Brewster, of kindly John Carver, and of "the good doctor," Samuel Fuller, of handsome, sunny-natured 


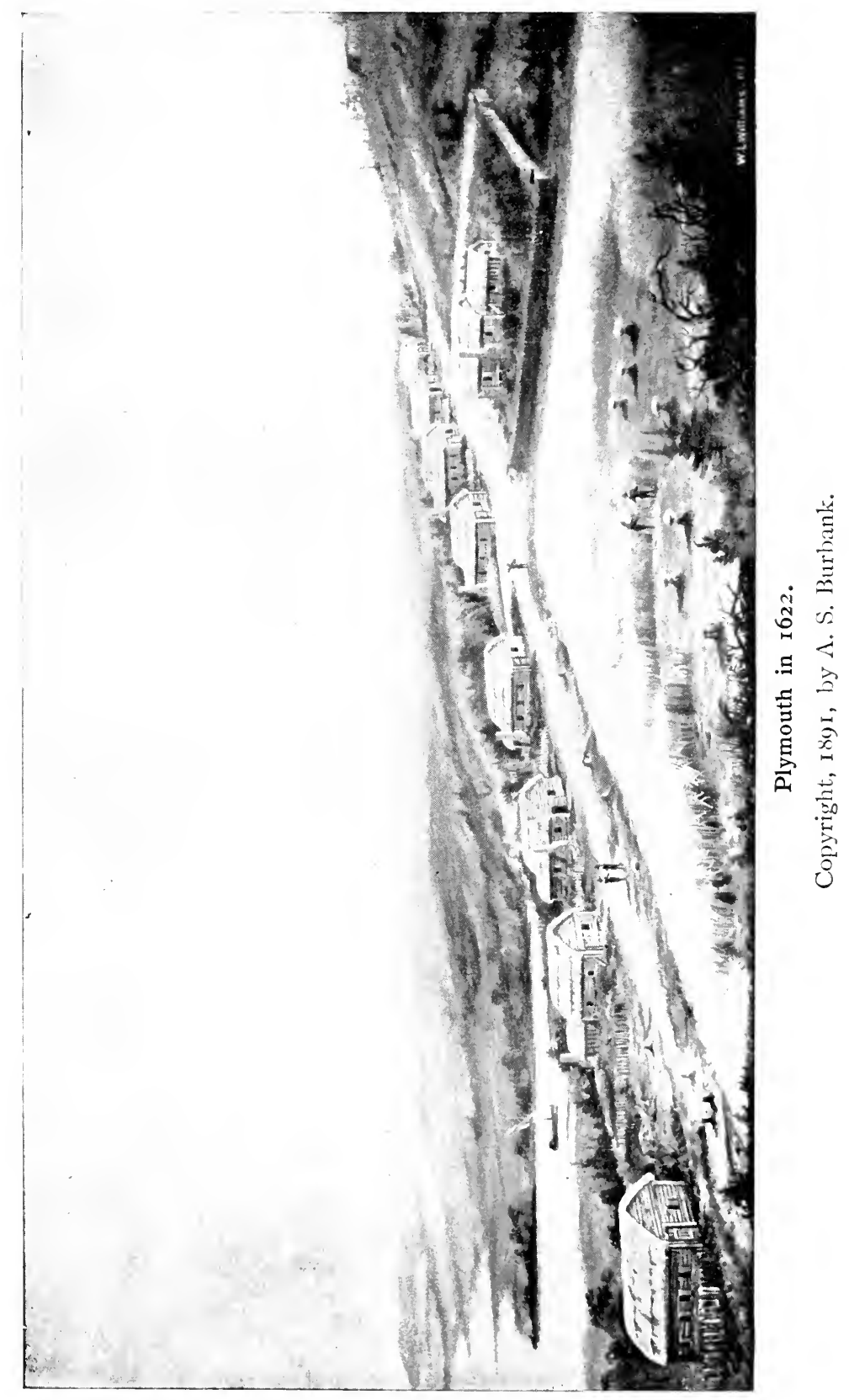





\section{wamen of the sidaptlower}

Edward Winslow, whom Master Bradford had called "our one born diplomatist," and of Miles Standish, the fierce-looking little man who had fought in the wars and who though not of their faith was yet a friend.

We can picture the impatience of Priscilla and the other Puritan youngsters, and of their mothers as well, who were obliged to stay on board while the men were exploring the country and finding wonderful things in this strangest of lands, which they could not yet even see except at a distance of three quarters of a mile. We can imagine the grave discussions as Captain Standish marshalled his military force of sixteen picked men, all of whom had swords and wore corslets and carried matchlocks or snaphangers. This martial display was not looked upon with approbation by the little congregation, and was only permitted after William Bradford, Stephen Hopkins, and Edward Tilley were named as a council of advice, whose opinion must be taken before any warlike demonstration was entered upon. What a commotion it must have caused when the fierce-looking Miles Standish and his militant company of churchmen started on that famous exploring expedition! We can almost 


\section{I24 Dioneer Mothers of America}

see the eagerness with which the children and their elders watched the little party land and pass up the sands and into the woods of red cedar, oak, pine, and sassafras and so out of sight. With what misgivings and prayers the wives and friends of those bold explorers must have waited for the three or four days the party was away! And when they came back, what a night that must have been in the cabin of the Mayflower as the returning heroes recounted their adventures and showed their spoils: the ancient ship's kettle which they had found buried and in which were three or four busheis of maize with ears of yellow, red, and blue, a wonderful new grain; and the noose of Indian hemp made for catching deer, in which William Bradford had been caught, to the great amusement of his comrades, and which they carried home as they did the corn, "to be paid for when they found the owners"!

On Monday, November 24th, the women went ashore for the first time and inaugurated the great American institution, "Wash-day Monday." Fresh water on board the vessel had been too precious to allow much washing of clothing and we can suppose that Priscilla was 


\section{Trlomen of the SManflower}

among the party, enjoying her freedom, the fresh air, and the fragrant smoke of the red cedar burning under their wash kettles.

"There did the Pilgrim fathers,

With matchlock and axe well slung,

Keep guard o'er the smoking kettles

That propped on the crotches hung.

For the earliest act of the heroes,

Whose fame has a world-wide sway,

Was-to fashion a crane for a kettle

And order a washing day."

It was upon this washing expedition that a number of the women caught the colds which, a few weeks later, developed into the quick consumption that carried them to their unmarked graves in the old Indian cornfield.

There came a second exploring expedition, and then a third in which twelve of the Pilgrims and six of the ship's crew went back into the country where they had an encounter with the Indians. This "first encounter" seems to have brought harm to no one, though many arrows were shot and considerable powder and bullets wasted. Sixteen of the arrows were picked up and sent back to England. On the following Monday, December 2oth, the exploring party, after coasting the bay in their shallop, landed at 


\section{I26 Dioneer Mothers of America}

Plymouth Rock, from which event came "Forefathers' Day," first celebrated in I769. Here they found cleared land and running water and a hill for defence, "a place good for the situation" of the settlement they were to make. Next day they carried the news back to their people on the Mayflower, and on December 25th the vessel hoisted anchor and ran across the bay to Plymouth, as the point had been named by Captain John Smith six years before, but it was not until five days later that they decided, by a majority vote in the cabin of the Mayflower, to build there. Owing to bad weather, sickness, and other reasons it was not until January 27 th that the town was laid out and the plots of ground assigned. First, they put up a common building, twenty feet square, which was to be at once meeting-house, barracks, and commissary - the first public building in New England. It was built of hewn logs with the cracks between plastered with mud. The roof was thatched with swamp grass. There was a great chimney, but we can fancy that these town-raised men were but poor chimney builders; at any rate the chimney caught fire and the blaze could be seen from the ship, where it was supposed that 


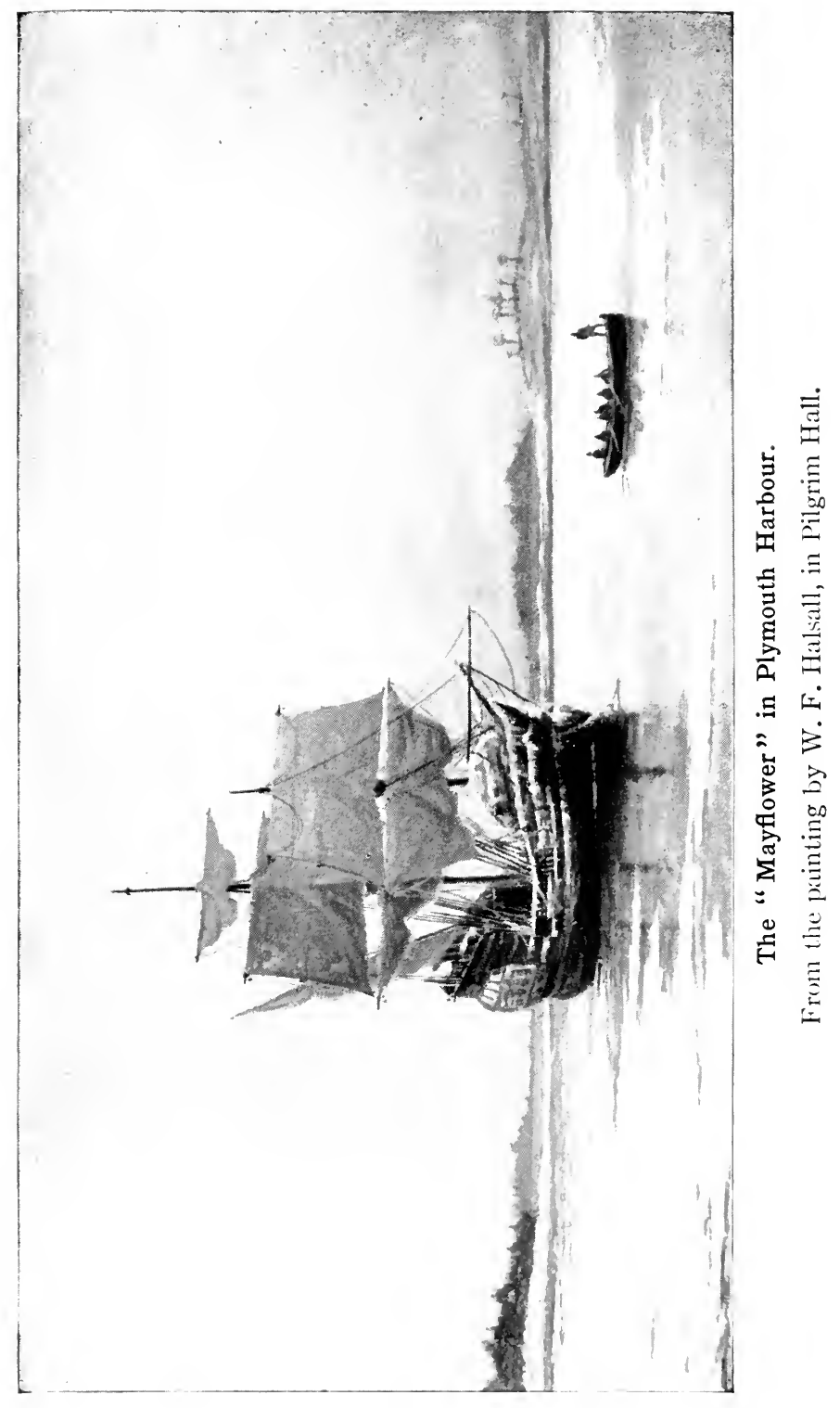





\section{ralomen of the sidauflower}

the Indians had attacked the settlement and burned the building. On Sunday, January 3 Ist, the whole company were on shore and divine service was held in the meeting-house. Of course, Priscilla was there in open-eyed admiration at the strange new structure. And there also must have been Mary Chilton, filled with pride at her triumph at having been the first woman to place her foot on the big boulder, which was their landing-place-Plymouth Rock.

The story of the sickness and suffering of that first winter in Plymouth has been told too well and too often to need recounting. As was to have been expected, when we consider the crowded condition of the ship's cabin in which the passengers had been kept for more than two months, with hatches battened down and little chance for ventilation and less for cleanliness, they were in a sadly run down and depleted condition physically. There could not have been a more pestilential atmosphere, and their ship food with its lack of variety, especially in the matter of fresh meat and vegetables, was not calculated to build up either strength or resistance. Then came four or five weeks' exposure to the damp and cold of the bleak New England 


\section{I30 Dioncer SDothers of America}

coast. The first house built became a hospital, "as full of beds as they could lie one by another." Nearly every person was sick at one time or another, and one half the company died of quick consumption inside of a year and most of them during the winter and spring.

Through all the records of this sickness and suffering there is little mention of Priscilla, though we know that she was there. Her father died in February and his death was followed a few days later by that of her brother Joseph. Then Robert Carter, their man, died and soon afterward her mother was taken and Priscilla was left an orphan. We do not know except by tradition in which of the families she lived afterward nor even the date of her marriage to John Alden. Hers was not the first marriage in the Colony, that honour having come to Susanna, the eleven weeks' widow of William White, but it seems to be generally agreed that Priscilla was married in 1622 , and Bradford records that in I627 John Alden and Priscilla had two children, Elizabeth and John, the eldest of whom was born in 1623. In 1650, according to Bradford, John and Priscilla had eleven children, all of whom were living. Priscilla was a grandmother 


\section{Orlomen of the sidapflower}

at the time, her eldest daughter Elizabeth, who had married William Paybody, being the mother of five children. A genealogical writer who attempted to trace the family twigs and branches has said: "To-day the descendants of JohnAlden and Priscilla are like the stars in the heavens in their multitude." It was a long-lived strain too, a great-grandson dying in $182 \mathrm{I}$, aged 102 years, and there was a great-great-granddaughter who died in 1845 . This descendant in her later years used to tell her own granddaughter the story of Priscilla's courtship as Priscilla had told it to her mother long years before.

It matters not how much of fact or fiction enters into the poet's metrical tale of the courtship of Miles Standish, it is one of those beautiful heart stories which we would wish to accept as truth. Yet the same iconoclasts who try to break down the romance of Pocahontas because of some seeming discrepancy in the written records of Captain John Smith, would tear from our books and our hearts another of those old traditions which we have been glad to believe without questioning. And all because the poet, like John Smith, was over-zealous in the matter of artistic and ornamental details. For instance, the poet says: 
"Then from a stall near at hand, amid exclamations of wonder,

Alden the thoughtful, the careful, so happy, so proud of Priscilla,

Brought out his snow-white bull, obeying the hand of its master,

Led by a cord that was tied to an iron ring in its nostrils, Covered with crimson cloth, and a cushion placed for a saddle.

She should not walk, he said, through the dust and heat of the noonday;

Nay, she should ride like a queen, not plod along like a peasant.

Somewhat alarmed at first, but reassured by the others, Placing her hand on the cushion, her foot in the hand of her husband,

Gayly, with joyous laugh, Priscilla mounted her palfrey."

Of course the records kept by the painstaking and painfully accurate Bradford go to show that no cattle arrived until 1624 , and it was not until 1627 that there were cattle enough to divide, and even then, John and Priscilla and their two children owned but four-thirteenths of "Raghorn," the Howland family of nine having claim to the other nine-thirteenths. Further, Raghorn is set down in the chronicles as a heifer.

The tradition is, however, far older than Longfellow's version, as there was a crude ballad 


\section{rullomen of the simanflower}

printed in 1762 in the New York Rover reciting the story, and the great-great-granddaughter referred to above claimed to have heard the essential details at first hand before the Courtship of Miles Standish was published. In this connection, however, it is interesting to note that the valiant captain of Plymouth, whose wife, Rose Standish, died only a few days after the landing of the Pilgrims, married her sister Barbara, and that in the course of time Alexander, the eldest son of Miles Standish, married Sarah, the second daughter of Priscilla and John Alden.

This same John Alden seems to have been a rarely lucky young man. For one not within the charmed circle of the Leyden congregation to have won the friendship of Bradford which lasted a lifetime, and to have won the hand of the gentle Priscilla who was well dowered financially as well as physically and mentally, was something for the young cooper whom the congregation had picked up at Southampton, simply because the law made it obligatory for the vessel to carry a cooper. ${ }^{2}$ We know that he was one of the signers of the compact and that he was very active in all the work of the Colony. We 


\section{I34 Dioneer Motbers of America}

read of him joining with Bradford, Standish, Allerton, Winslow, Howland, and Prence in underwriting the debt of eighteen hundred pounds which Allerton had contracted in buying out the London Company of Merchant Adventurers who had financed the Colony when they first came over. This made the eight men named virtual owners of the plantation and permitted them to reorganise the Colony, which they did by dividing the land into shares of twenty acres each, giving to each settler described and enrolled as a purchaser one share in addition to the land he already possessed.

A year later, 1627 , we find that the community had twelve cows, which, like the land, were assigned by lot to each of the divisions. This was an important year for Plymouth. Counting those who had come to stay or who had been born there, the total number was now 267. Fiftyeight had died and fifty-three had removed, but after that awful first winter only six persons had died in six years.

It was about this time that Governor Bradford received a letter from Isaac de Rassières, secretary of the West India Company's government at Manhattan, and later a visit, 


\section{rulomen of the sidapflower}

at which both parties courteously warned the other to keep to his own territory in the matter of trading. The Dutch at that time claimed 270 settlers on Manhattan and up the Hudson. It was de Rassières who showed the Pilgrims the advantages to be gained by using as currency the Indian wampum. In I630, the Council of New England granted to the Colony a new patent, which included a grant of land fifteen miles on each side of the Kennebec River, and the settlers set up a trading post on the site of the present city of Augusta. In 1633, we find the little Colony out of debt and prospering and ten years later fast spreading far beyond its original boundaries. Miles Standish, William Brewster, and John Alden had founded the village of Duxbury, Edward Winslow was at Marshfield, and there were six other villages which confederated as Plymouth Colony. It was this same year, I643, that the "New England Confederation" was formed with the two Massachusetts colonies, Plymouth and Massachusetts Bay, and the two Connecticut colonies, New Haven and Connecticut-the first step towards that confederation of all the colonies that was in the future to throw off all restraint by foreign 


\section{I36 Dioneer Sibotbers of Elmerica}

government. Two men, church members, from each colony were chosen by local town meetings as delegates to an annual meeting each September. This little legislature of eight had charge of war and of defensive measures, boundary disputes, the making of roads, and the rendition of criminals and servants. Each colony managed its own local affairs, which included religious and educational matters. In 1675 , it was claimed that there were not less than 43,000 people in the confederation, of which about one half were in Massachusetts and 7000 in Plymouth Colony. In I692, Plymouth Colony was by royal edict made a part of Massachusetts Province and as a unit the colony was a thing of the past. This is in brief an outline of the coming of the Pilgrim fathers, one of the great white milestones that marks the world's progress-after Columbus the most famous voyage in American history.

But to return to the Pilgrim mothers, those devoted women from whom were to come so many of the distinguished men and women of the nation.

\section{Susanna White}

Susanna White was the first mother in the 


\section{Wulomen of the Sildanflower}

Colony of Plymouth, a son having been born to her and her husband William White while the Mayflower rode at anchor in Cape Cod Bay; he was named Peregrine. Susanna had married William White, who was a widower, in Leyden and at the time of the landing they had already one son, Resolved White, four or five years old. William White died in February, I62I, and in the following May, Susanna became the wife of Edward Winslow, whose wife had also died of the "first sickness." She thus became the first bride in the colony. Of her life thereafter we can only conjecture from the career of her husband and children. Baylies says, in noting the death of her second husband, Governor Winslow, in May, I655:

"To have been the first mother and the first bride in a country which has produced a race so distinguished as the New Englanders would have been cited by the ancients as an instance of rare and happy fortune. If we add to that the peculiar happiness of having been the wife of a distinguished governor of his own colony and the mother of another equally distinguished, who to his other added the high and solitary honour of having been the 


\section{I38 Dioneer SiDothers of America}

commander-in-chief of the forces of the confederate colonies in a war involving their existence, her fortunes may be regarded as transcendently prosperous."

Edward Winslow died, as stated, in I655, while on shipboard bound for Jamaica, where he had been sent as a commissioner by Oliver Cromwell. The son to whom the historian Baylies refers was Josias Winslow, Governor in I675, and commander of the forces of the confederated colonies of Massachusetts Bay, Plymouth, Connecticut, and New Haven in King Philip's War. By her second husband, Susanna White Winslow had four children, as noted by Bradford in I629, while his record of 163 I refers to Edward Winslow's marriageable daughters. Both of Mrs. Winslow's sons by her first husband lived to a good old age, Resolved White having died after I690, while Peregrine White, "the Plymouth Rock baby," died at Marshfield in I704. Noting the death of Captain Peregrine White, the Boston News Letter of November I5, I704, says: "Although he was in the former part of his life extravagant, yet he was much reformed in his last years and died hopefully." 


\section{Tramen of the Sidaffower}

\section{Elizabeth Winslow}

Elizabeth Winslow, the first wife of Edward Winslow, met her husband in Leyden, where she was one of Pastor Robinson's flock, while he was travelling on the Continent for pleasure. Her maiden name was Elizabeth Barker. Before this, young Winslow had become "convinced" and decided to cast his lot with the exiles. Their marriage took place in 16r6. They had no children with them on the Mayflower, but brought a girl named Ellen More, evidently an orphan, whose two brothers were also of the party as wards of Elder Brewster and Governor Carver. All three of the More children died within a year after their arrival, and Mrs. Winslow herself passed away in March, 162I.

\section{Mary Brewster}

Mary Brewster, wife of Elder William Brewster, was probably the oldest woman to undertake the voyage, being about fifty-one at the time of her death in I626. Two sons, Love and Wrestling, aged seven and five years respectively, came with their parents to Plymouth. The latter died "a young man, unmarried," accord- 


\section{I40 Dioneer Mothers of America}

ing to Bradford's record in 1650 , and at that date it was said that Love Brewster was still living and had four children. In all, Mrs. Brewster was the mother of eight children, two of whom were born in the colony. These were the sons, Jonathan and Willis. Of the four daughters, the two elder, Patience and Fear, came over in I623. Patience Brewster in I624 became the wife of Thomas Prence, who was Governor of the colony at the time of his death in 1675 . She died before 1635 , leaving two children. Fear Brewster became the second wife of Isaac Allerton, who was one of the most distinguished of the Pilgrims. In I650, Bradford writes: "She hath one son living but she is long since dead."

\section{Elizabeth Hopkins}

Elizabeth Hopkins, wife of Stephen Hopkins, was the mother of three children, one of whom, born aboard the Mayflower during the voyage, was given the name Oceanus, and another, a daughter born in Plymouth, who died in childhood. The oldest of her children, Demaris, who came to Plymouth on the Mayflower, married 


\section{Wullomen of the sibaptiower}

Jacob Cooke, and died there some time between I666 and I669. Elizabeth Hopkins died before her husband, whose death took place in 1644 . Closer than that it does not seem to be fixed. It is interesting to note that the boy Oceanus, born of the sea, died a seaman in the Barbadoes before 1650 . There were also in the Hopkins' family, on the voyage, his two children by his first wife, Giles aged fifteen years, and Constantia aged eleven, who became the wife of Nicholas Snow of Eastham and "the mother of twelve children and one of them married," according to Bradford's record of I650. She died in 1679 .

\section{Dorothy Bradford}

The first woman to die among the Mayflower's passengers was Dorothy, wife of William, afterward Governor, Bradford. She fell overboard in Cape Cod Bay on December 7, 1620, and was drowned. She was from Wisbeach, England, and her father was among those who joined in the migration to Holland and was still living at Leyden in 1625. According to the records, "William Bradford, fustian maker, a young man of Austerfield, England, and Dorothy May" 


\section{Pioncer SDotbers of America}

were married at Leyden on November 30, 1613. They had a son who did not accompany his parents to America. For his second wife, Bradford married the widow of Thomas Southworth, who came to Plymouth after her husband's death, probably in I622, accompanied by her two little sons. One of these, Captain Thomas Southworth, was Assistant Governor at the time of his death in I669, and another brother, Constant Southworth, succeeded him in office. By her second husband, Alice Bradford had three sons and a daughter. The eldest of the sons, William Bradford, attained high honours in the Colony. Alice Bradford is described as having been "a lady of extraordinary character and worth."

\section{Helen (Elinor) Billington}

Helen (Elinor) Billington, wife of John Billington, came on the Mayflower with her husband and two sons, John sixteen, and Francis fourteen, years old. The family did not belong to the Leyden congregation and her lot does not seem to have been a pleasant one in the community, largely because of the rough temper 


\section{ralomen of the Inaptlower}

and unconventional bearing of her husband, who came to be known as the "scapegrace of Plymouth." Bradford says of him: "He and some of his had been often punished for miscarriages before, being one of the profanest families among them. They came from London and I know not by what friends shuffled into the company." Billington had his first serious trouble when he "cursed" Captain Standish and refused to obey orders. He was tried by the "whole company" and "condemned to have heels and neck tied together, but afterward humbling himself and asking pardon was forgiven." This was on March 20, I62I. He was in divers other troubles owing to his bad temper and worse language, and the two boys managed to keep themselves prominent in the little community. The boy Francis, who was left behind with the women and children during the time most of the men were away on one of their first exploring expeditions, managed to get hold of a gun and some powder. He shot the gun several times, made squibs and set them off, and finally fired a fowling-piece in the cabin where there was a keg of powder half full and uncovered. A fire was kindled within a foot or two of the open 


\section{I44 Dioneer Motbers of Emerica}

powder when discovered. Of course there was a great scare and complaints to the father and the elders, probably followed by vigorous chastisement, as those were days when the child was not spoiled by sparing the rod. The next prank of the Billington boys that gets into the records was when John, Jr., near the end of July, I62I, got lost and strayed for five days, living on such roots and berries as he could find. $\mathrm{He}$ was rescued by some of the friendly Indians about twenty miles from home and returned to the colony. Later we find where Mistress Billington was fined five pounds for slandering John Doan. She was also "whipped and set in the stocks" for the same offence. What the slander consisted of is not set down, nor indeed whether both or rather all three punishments were for the same offence, or whether the good woman kept pursuing the luckless Doan with her slanderous tongue, or not. In I630, there came a quarrel between John Billington and John Newcomen while they were out hunting, and in a fit of temper Billington managed to put a bullet into his adversary, from the effects of which he died. Billington was arrested, tried by the "whole company" again, and condemned 


\section{Trlomen of the Sinaftlower}

to death under provision of the code of laws agreed to in their Mayflower compact. Billington questioned the power of the Colony to inflict capital punishment, and the matter was finally referred to the Puritan Governor Winthrop and his counsellors as a court of appeals. The sentence was carried out, considerably to the grief of many of the Plymouth men who would have given a lighter sentence could they have done so.

Eight years after the execution of her first husband, Mrs. Billington became the wife of Gregory Armstrong. The old marriage contract is still on file at Plymouth which reads: "Whereas the said Ellenor Billington (widow) hath two cows, which the said Gregory Armstrong is presently to enter upon, the said Gregory doth covenant and graunt that if it pleases God that he happen to outlive the said Ellenor, he shall and will at her decease give two heifers to Francis Billington her son." Francis Billington was still living in 1650 and was the father of eight children. His brother John died a young man and unmarried.

\section{Bridget Lee Fuller}

Bridget Lee Fuller, wife of Samuel Fuller, so 


\section{I46 Dioneer Silpothers of America}

"the good doctor" of the Mayflower, did not

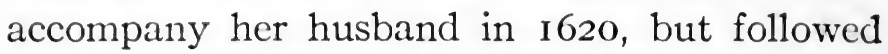
him in 1623. They had two children "both living and grown up" in I650. She was the daughter of Joos Lee of Leyden, where she was married to Fuller in 1617 , and was his third wife. Edward Fuller, a brother of Samuel, came on the Mayflower with his wife and little son, Samuel. The wife died of the "first sickness" and not even her maiden name graces the records.

\section{Ann Tilley}

Ann Tilley, wife of Edward, and Bridget, the wife of his brother John, came from Leyden and all four were carried away by the sickness of the first winter. Ann Tilley had no children, but she and her husband brought with them two cousins, probably of the husband, Humility Cooper and Henry Sampson. These children after the death of the Tilleys were brought up in the family of Thomas Prence. Bridget Tilley and her husband had one daughter, Elizabeth, thirteen years old when she landed from the Mayflower. She afterward married John Howland who came over in the family of Governor 


\section{renomen of the Mauflower}

Carver. Both were living in $165^{\circ}$ and Bradford records that they had ten children and five grandchildren living and "other marriageable daughters."

\section{Susanna Chilton}

Susanna Chilton, wife of James Chilton, came from Leyden with her husband and both died within a year. With them came their daughter Mary Chilton, who married John Winslow, brother of Governor Edward Winslow. She died in Boston in 1679. Bradford's records show that in $165^{\circ}$ she was the mother of nine children. She had a sister who was left behind in Leyden but came to the Colony later and was married.

\section{Katharine Carver}

Katharine Carver, wife of the first Governor of the Colony, recovered from the "first sickness" of which she was one of the earlier victims only to nurse her husband through the attack which carried him to his grave. Then she fell sick again and did not recover. The Carvers were devoted to each other and it was believed in the Plymouth community that she died of a broken 


\section{I48 Dioneer SiDothers of Êmerica}

heart. It is rather surprising how little seems to be known of the Carvers. He was the first signer of the compact aboard the Mayflower, and was unanimously chosen as the colony's first Governor, a fact that attests his standing not only with Elder Brewster but with the congregation. They brought no children with them, though there were eight in their household. The names of no children are mentioned in the Governor's papers, official or personal, but a grandson is said to have been living in Marshfield as late as $175^{\circ}$, at which time he was I02 years old and the chronicle adds: "that in that year he worked in the field with his son, grandson, and great-grandson, while a baby of the fifth "generation was in the house." It also adds that the centenarian finally died of a sunstroke. The "first sickness" claimed two of the Governor's household, his man, Roger Wilder, and the little boy, Jasper More. Governor Carver himself died May 6th, of sunstroke, and "his wife, who was strongly attached to him, overcome with sorrow, survived him but six weeks." With the Carvers lived a little girl, Desire Minter, aged about sixteen. She returned to England after the death of Mrs. Carver. 


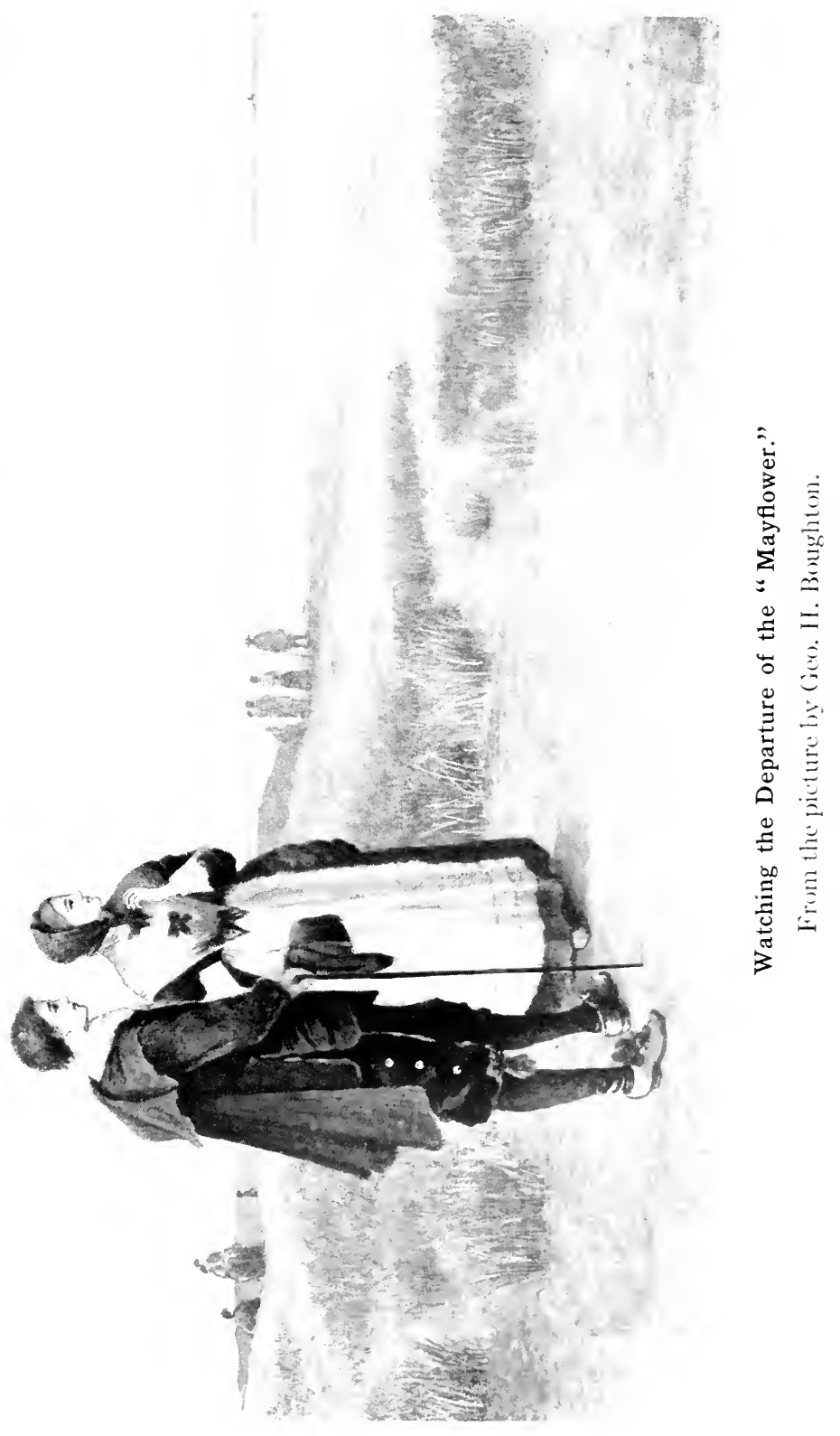





\section{ralomen of the sibanflower}

Mrs. Carver's maid married in Plymouth and died there within a year or two, but neither her name nor any other record has been preserved.

\section{Sarah Eaton}

Sarah Eaton, wife of Francis Eaton, came with her husband and infant son on the Mayflower. She died in the "first sickness."

\section{Mary Allerton}

Mary Allerton, wife of Isaac Allerton, was born at Newberry, England. Her maiden name was Norris and her parents were among the first, like the Allertons, to seek refuge in Leyden. Allerton gives his birthplace as London and his occupation as that of tailor. Mary Allerton died in February, I62 I. She left three children, Bartholomew, aged eight years, and two little daughters, Remember and Mary. The latter, who became the wife of Thomas Cushman, died in Plymouth in I699, the last of those who came over on the Mayflower.

\section{NOTES TO CHAPTER III}

r Plymouth Colony was founded by the congregation of one of the little "Separatist" churches, which believed that any body of Christians had the right to worship, independent of external authority, even that of the state. Persecuted at home (Scrooby, Eng.) they 


\section{I52 Dioneer Mothers of Almerica}

fled to Holland in 1608 , living twelve years at Amsterdam and Leyden. They then decided to return to England and emigrate to America, which they did in 1620 , on the Mayflower.

"Ale or beer was then a part of the daily diet and of course the Mayflower being stocked for a long voyage carried a considerable number of kegs or barrels. A provision of the law was to the effect that "whosoever shall carry beer beyond the Sea shall find sureties to the customers of that port to bring clapboard meet to make so much vessel as he shall carry fourth." It was the cooper's business to prepare such clapboard (staves), and so John Alden being a journeyman cooper was hired and had decided to join the congregation and remain with it, before the vessel reached Cape Cod Bay. 
"HISTORY is generally written by men, who dwell on politics, wars, and the exploits of their sex. Household affairs, women's influence, social customs and manners, are seldom chronicled and are only to be discovered underlying what are deemed the important events of life, more by inference than from anything that is actually writlen about them."

Mrs. John King Van Rensselaer. 



\section{Chapter IV}

\section{Annetje Fans, Hew Work}

A splendid type of the sturdy, thrifty, capable Dutch women who came first to New Amsterdam-Her husband, Roelof Jans, was farm superintendent for Patroon Killiaen Van Rensselaer I630 to 1635 -Removed his wife and five children from Fort Orange to Manhattan Island, where he was given one of the farms reserved by the West India Company, upon which he died soon afterward-The widow married Dominie Bogardus in 1638 and bore him five children before he was lost at sea in I646Annetje Jans's farm a subject of litigation for two centuriesThe story of her descendants, with those of Cornelia Lubbetse, Annetje Lockermans, Margaret Hardenbroeck, Katrina Van de Brough, and Arientje Jans, is largely the history of New York for a century.

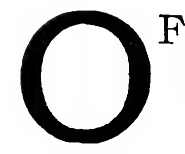

all that little band of sturdy, thrifty, capable Dutch women who came first to dwell in New Amsterdam, Annetje Jans is probably the best remembered. This is not that she in any striking particular surpassed her sisters among the good vrouws, worthy woman that she was, but rather because of the two centuries of litigation that grew out of the disposition of the property that she left behind. But though Annetje Jans is best remembered as a woman who owned a section of New York, 


\section{Dioneer Mothers of Emerica}

now worth a king's ransom, she is chiefly interesting to us as a type of as remarkable a collection of women as can be found in history, and the story of AnnetjeJans Bogardus, Cornelia Lubbetse de Peyster, Margaret Hardenbroeck Phillipse, Katrina Van de Brough Beekman, and Annetje Lockermans Van Cortlandt and their descendants is largely the history of old New York for the better part of a century.

"To the courage and thrift of the Dutch women who ventured to America, the wealth and prosperity of the colony was largely due," writes Mrs. John King Van Rensselaer. "It is a well authenticated fact that the women of the Dutch Netherlands of the sixteenth and seventeenth centuries were more highly educated, better protected by the laws of the country, and held a more prominent position than any of their contemporaries. Holland was the only country in which girls received the same education as boys and shared their studies, until the boys were old enough to select a trade or profession for themselves, when the girls were withdrawn from school and carefully trained in household duties. When England, France, Spain, Germany, and Italy restrained their 


\section{Annetje Jans, Hew Dork}

girls and treated them as toys, denied them education and prevented their independence, the men of the Dutch Republic of two centuries ago recognised the equality of their women, educated them to fill responsible positions and encouraged them to cultivate a love for literature and music. The sensible education bestowed on the woman of Holland quickened her judgment, and the enlightened laws that permitted her to hold real estate and to carry on business in her own name, whether single, married, or widowed, gave her confidence and independence, so that it was no uncommon thing to find women venturing their own savings in mercantile pursuits, quite independent of the men of the family, who never questioned the right and propriety of such proceedings."

Annetje Jans ${ }^{\mathrm{I}}$ was the daughter of one Tryntje Jonas, a respectable widow living near Rotterdam, who sought and obtained employment with the Dutch West India Company to come to America as professional nurse and midwife. She came over in 1630, in the good ship Endracht, accompanied by her daughter Marritje and her. husband, a carpenter named Tymen, also an employe of the West India Company. On the 


\section{I58 Dioneer Mothers of Elmerica}

same ship came Annetje Jans and her husband Roelof Janssen and their three children, Sara, Katrina, and Fytje.

While Tryntje Jonas and her daughter Marritje were bound for the little settlement on the island of Manhattan, Roelof Janssen and his brood were going up the Hudson to Fort Orange, near which Killiaen Van Rensselaer the Patroon was establishing his manor, and where the young emigrant was under contract to act as bouwmeester, or farm superintendent, for three years at a salary of I 50 to I 80 guilders a year. There is not much to be told of their life at Beverswijck, except that the daughters were carefully trained in all housewifely duties as their mother had been before them, that the Indians were frequent and friendly visitors, and that all three of the girls learned to speak their tongue as they did English and Dutch. Also it would appear that nurse Tryntje Jonas and her family had been visitors, as the Patroon writes from Holland to his director: "I see that Roelof Janssen has been making a fine run on me for provisions-aye pretty much all the rations there were in stock. I think that his women, mother and sister and the others, must have 


\section{Ennetje Fans, Mew Work}

given away, which must not go on." Roelof Janssen remained with the Patroon five years and then, having accumulated an outfit of stock and farming implements as well as two more children, he removed to Manhattan Island, where the Company, or rather Wouter Van Twiller, the Governor, gave him one of the eight farms reserved by the Company. Possibly this may have been because it was thought that it was well to have on one of its principal farms the services of an expert farmer with five years' practical experience in the new country.

Notwithstanding the fact that Manhattan had been settled in I6I3, the colony was still not much more than the little handful of fur traders that Peter Minuit had found when he came over in I626. Two years before that date the first shipload of settlers had come to America, of whom eight men and one woman, Catelina de Trice, ${ }^{2}$ landed on Manhattan and the others went on up the Hudson to Fort Orange. By I635, the year that brought Roelof Janssen to Manhattan, it was estimated that there were about two hundred persons, all told, in the little colony. Janssen at once set about building a house on the irregular tract of land that had been 


\section{0

given him. This farm lay around the base of a hill, somewhat west of the present line of Broadway, called Kalch hoek or Chalk hook. The southern boundary was about the Warren Street of to-day and the northern, Canal Streetin all about sixty-two acres and but little of it cleared. Shortly after the house was completed and some preparation made for his first planting, he died and Annetje was left alone with her five children. She did not remain a widow long, as in the spring of 1638 she was married to Dominie Everhardus Bogardus, whom the paternal West India Company had sent over to look after the spiritual needs of the little colony, as Adam Roelandtsen, the schoolmaster, and Dr. Hans Kierstede, the surgeon, were sent to minister to their intellectual and physical wants. Both the doctor and the schoolmaster had their houses on Parel (Pearl) Street, and near them lived Nurse Tryntje Jonas, the first woman to practise the medical profession in New Amsterdam.

Dominie Bogardus, who had one of the best houses in the Colony, lived on Whitehall Street. He has been described as "large, graceful, sinewy, and strong, with a fine, broad, open, frank face, 


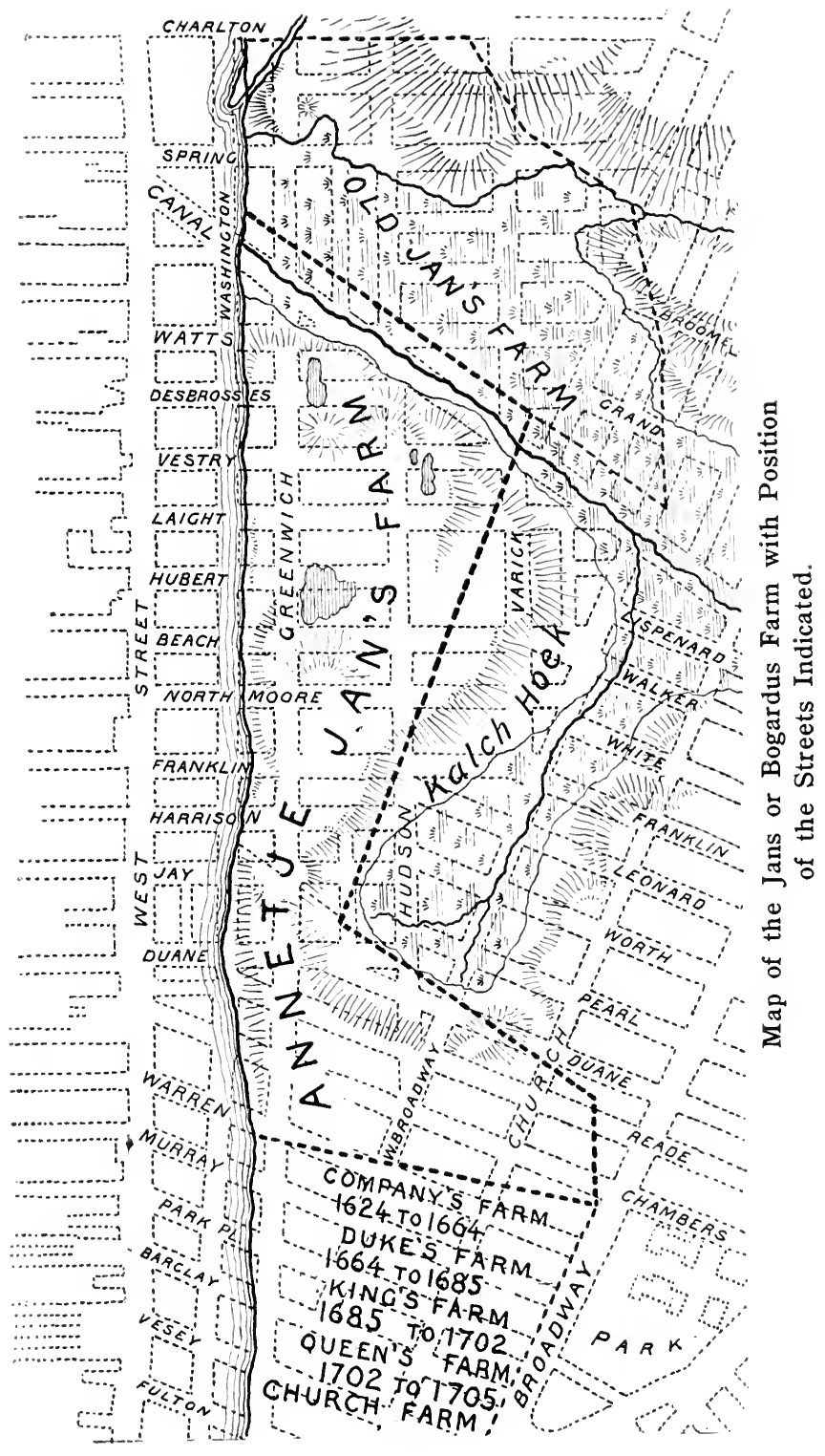





\section{Ennetje Jans, Mew Work}

high cheek-bones, a dark piercing eye, and a mouth expressive of the very electricity of good humour, which was partly hidden by a beard cut in the peculiar fashion prescribed for ecclesiastics during the reign of Henry IV." The same writer has described Annetje at the time of her second marriage as "a small, well formed woman with delicate features, transparent complexion, and bright, beautiful dark eyes. She had a well balanced mind, a sunny disposition, and a kind heart." The Dominie was a man of choleric temper and given to plain speech, as was shown by occasional remarks from the pulpit concerning public affairs and characters. His house overlooked the river and, standing close to the little peak-roofed church, has been described as one of the most attractive places on the island and "noted for the beautiful vines that climbed over the low-pitched roof and the beds of gay flowers, all of which were due to the housewife's love of plants and her faith in the virtue of herbs and simples, and while the Dominie cured the souls of his parishioners, it was to his wife all turned for aid in sickness."

With her marriage, Annetje seems to have passed the active management of her farm over 


\section{I64 Pionecr SiDotbers of Elmerica}

to her husband, who had also acquired some land in his own right on Long Island, which was known as the Dominie's Hook, as the Janssen farm came to be called the Dominie's Bouwerie or the Bogardus farm. In 1639, we find that the Reverend Everhardus Bogardus leased to Richard Brudenell a "tobacco house and plantation, with a water dog, gun, and powder, at a certain rental payable in tobacco, and one third of all the game he shall kill, as long as the powder and ball shall last." In another lease, dated August I 4, I642, Dominie Bogardus leased to one Rufus Barton the land "situated on the North River, belonging to him, Bogardus, during five years, beginning September, I642, and terminating September I, I647, when the harvest shall be brought into the barn; for all of which the tenant shall pay annually two capons as recognition." Bogardus reserved pasture for his own cattle, and Barton was required to build a house on a site to be named by Bogardus, who must buy the house at an impartial valuation at the expiration of the lease, which Barton could renew if he wished.

In a monograph on The Annetje Jans Farm, written for the "Half-Moon Papers" series, 


\section{Annetje Fans, Mew Work}

some years since, Ruth Putnam, who had made a most careful study of the subject from original sources, says: "It is evident that no rent could be commanded for the farm. The best the owners could hope for was to find some respectable tenant who should improve the property."

In June, I642, Sara Roelof, Annetje's eldest daughter, was married to Dr. Hans Kierstede, and the mother, not umindful of her daughter's interests, on that occasion repeated in legal formalities the document she had signed before her marriage to Bogardus, in which she had settled one thousand guilders upon her family and promised to "bring them up, with God's help, decently, provide them with necessary food, clothing, and let them learn reading and writing and a good trade." The original contract was signed and witnessed by Director Kieft, Councillor de la Montaign, and Cornelis Van Tienhoven. It is worthy of note that Sara Roelof had carried her education considerably beyond the stipulated reading and writing and among other things had become so proficient in the language of the Algonquin tribes that she was employed on more than one occasion as interpreter in the making of treaties. 
Toward the end of this year, Dominie Bogardus was lost at sea. He had sailed for Holland on the Princess, which was also carrying home Governor Kieft, who had been recalled by the Worshipful States-General. Again was Annetje left a widow, this time with four little sons, Willem, Cornelis, Jonas, and Pieter Bogardus, in addition to her elder family. The farm after this seems to have been looked after by her sonsin-law, Dr. Kierstede and Pieter Hartgers, who had married Fytje Jans, and her brother-inlaw Govert Lockermans, the third husband of Marritje Jonas. There is a record extant of a lease to Evart Pels for six years, May I, I652, to May I, I658, at a rental of two hundred and twenty-five guilders and thirty pounds of butter. The lease included "two mares, one colt, one stallion, two milch cows, and a calf taken at the joint risk of landlady and tenant." The latter might put up a new house; if he did not, he must put a new roof on the old one.

In 1653, the village of New Amsterdam was incorporated by the Director Peter Stuyvesant, and the sons-in-law of the widow Bogardus thought it best to make sure of her title in her property, and it is recorded that on July 4, I654, 


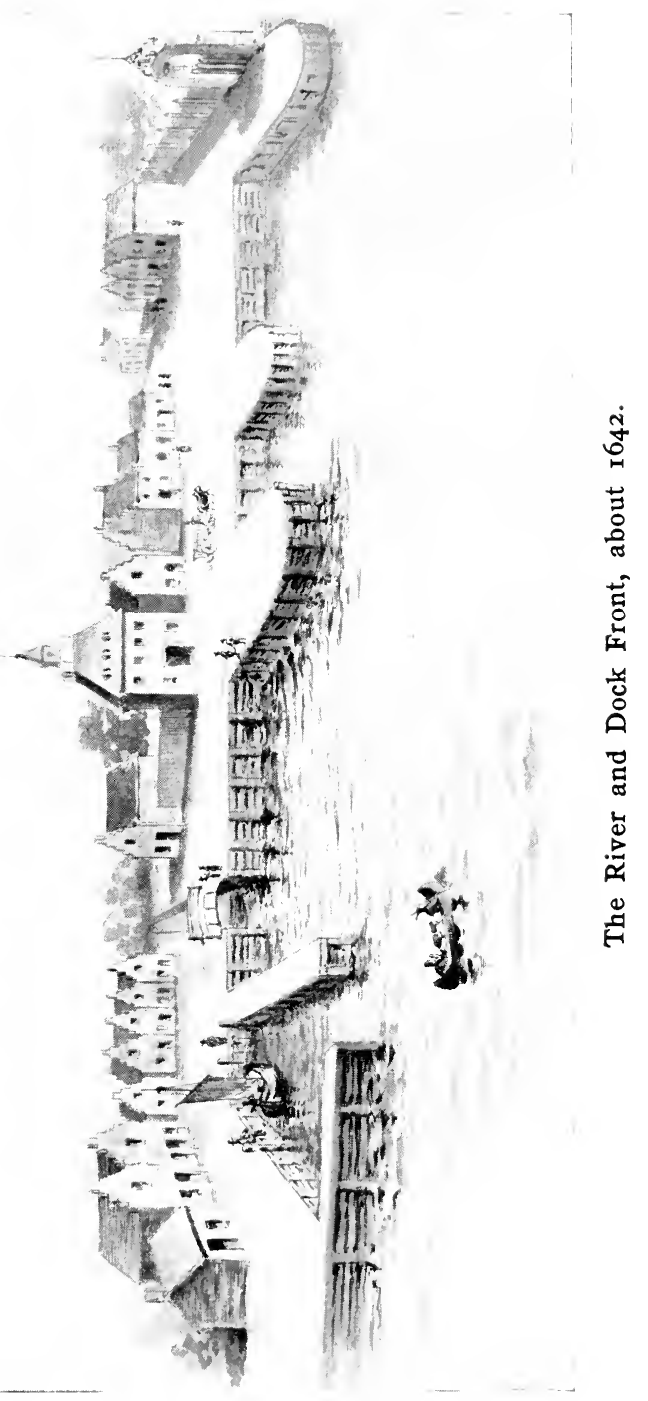





\section{Annetje Jans, MeW Dork}

Wouter Van Twiller's grant to Roelof Janssen was duly confirmed. The widow was not living in New Amsterdam at the time, but was a frequent visitor at the homes of her married daughters. After the death of Dominie Bogardus, she had removed with her children to Beverwijck, near Fort Orange, selling the house in New Amsterdam that she had inherited from her second husband. In 1663, Annetje Jans Bogardus made her will in which she names as her sole heirs, "Sara Roelofsen, wife of Hans Kierstede, Katrina Roelofsen, wife of Johannes van Brugh; also Jannetje and Rachel Hartgers, children of her deceased daughter, Fytje Roelofsen, wife of Pieter Hartgers, representing together their mother's place; also her son, Jan Roelofsen, and finally Willem, Cornelis, Jonas, and Pieter Bogardus, and to them bequeathes all her real estate, chattels, credits, money, gold and silver both coined and uncoined, jewels, clothes, linen, woollen, household furniture and all property whatsoever, to be disposed of after her death and divided by them in equal shares, to do with the same their own will and pleasure without hindrance whatsoever, nevertheless with the express 


\section{I70 Dioncer Sibother of America}

condition and restriction, that her four firstborn children first receive their bequest from their father's property, consisting of a farm lying on Manhattan Island on the North River, the sum of 1000 guilders out of the receipts or the value of the said Bouwerie before any other division takes place; and as three of these children, at the time of their marriage, received certain gifts, and as Jan Roelofsen is yet unmarried he is to receive a bed and milch cow, and to Jonas and Pieter Bogardus is given a house and lot, situated to the westward of the house of the testatrix in the village of Beverwijck, going in length to the end of the bleaching spot and in breadth to the room of her the testatrix, beside a bed for each and a milch cow for each of them, the above to be an equivalent to what the married children have received; finally, she, the testatrix, gives to Roelof Kierstede, the child of her daughter Sara, a silver mug; to Annetje van Brugh, the child of her daughter Katrina, also a silver mug, and to Annetje and Rachel Hartgers, the children of her daughter Fytje, a silver mug each; and to the child of Willem, named Fytje, a silver mug, all the above gifts to be provided for out of the first moneys re- 


\section{Ennetje Jans, Hew Work}

ceived, and afterwards the remainder of the property to be divided and shared as aforesaid."

A few days later the earthly pilgrimage of Annetje Jans Bogardus was brought to a close, and inside of another year (September, 1664) the British took possession of the town and New Amsterdam became New York. Governor Nicholls confirmed the grant of the Roelof Janssen property to the children and heirs of the widow Bogardus. The next year the farm had to be sold to pay the rooo guilders left the Roelof Janssen heirs, and Col. Francis Lovelace, the second English Governor, became the purchaser. The first farm north of the fort the West India Company had reserved for the use of the resident Director, or Governor, and it was known as the Company's Farm. When the English took possession it was called the Duke's Farm and still held for the use of the Governor. Lovelace bought the Bogardus farm and added it to the farm that he already held ex-officio. This seems to have been satisfactory to all concerned. The quaint old document whereby the property was transferred to Lovelace does not mention the price paid otherwise than as a "valluable" consideration. The thrifty 


\section{i72 Dioneer Mothers of Emerica}

young Dutch sons-in-law of the deceased Widow Bogardus must have felt satisfied or there would have been some action taken later when the Dutch admiral, Colve, took advantage of war between Holland and England to again take possession of New Amsterdam and for the next fifteen months it remained a Dutch colony. Lovelace fled, leaving his debts behind him, but if he defaulted on any payment to the Janssen heirs it was never made known as certainly would have been the case, as Johannes Van Brugh, one of the sons-in-law and the family's chief legal adviser, was in high favour with the Dutch Governor. No such protest seems to have been made, and when the Colony reverted to the English all of Governor Lovelace's property was confiscated by the Duke of York, who claimed that Lovelace was in debt to him for $£$ 70oo. After that, all lines of demarcation between the Duke's Farm and the Bogardus Farm were lost, and near the end of the seventeenth century, when Trinity Church parish was incorporated, Governor Fletcher gave the new corporation a lease of the whole farm for a period of seven years at an annual rental of sixty bushels of wheat. In I705, Queen Anne 


\section{Ênnetje Fans, Nhew Work}

granted "the Queen's farm" to Trinity Church forever. During all this time there does not seem to be any evidence that any of Annetje Jans's heirs ever expressed any dissatisfaction with the disposition of affairs; in 1738 , however, the heirs of Cornelis Bogardus began to question the occupancy of the property by Trinity Corporation. The contention of the claimants has always seemed more or less hazy, but succeeding decades of heirs have contributed of their substance to pay lawyers to prosecute their claims. No court has ever sustained the claims of the heirs in any particular, yet with each succeeding generation new claimants have appeared, though eminent jurists, both on and off the bench, have said that any possible right has long since been outlawed. In Schuyler's Colonial New York, the author, himself a distinguished descendant of Roelof and Annetje Jans, says: "In view of the repeated decisions of the judicial tribunals and of their publicity, any lawyer who can now advise or encourage the descendants of Annetje Jans to waste their money in any proceedings to recover this property must be considered as playing on the ignorance of simple people, and as guilty of conscious fraud and 


\section{I74 Dioneer MDotbers of America}

of an attempt to obtain money under false pretences."

That in brief is the story of the Annetje Jans Farm litigation which, by reason of the great and constantly increasing number of claimants and of their persistence in the face of continued defeat, has grown to be a cause célèbre. In I803, all the streets from Warren, north to Canal, covering the site of the farm, were laid out and the land, which had before been a part of Greenwich village, was ceded to the city.

To return to Annetje Jonas, the midwife's daughter, who from her rather humble position as wife of farmer Roelof Janssen became Mevrouw Bogardus in 1638 and went to live in the little vine-covered house on Whitehall Street. We read that shortly after her marriage, she went to pay a neighbourly call on Mrs. Van Corlear. Reaching the door, she overheard Grietje, the wife of Anthony Janssen, talking within. Anthony Janssen had recently used harsh and contemptuous language toward Dominie Bogardus, and Annetje resented it by turning away and walking in another direction. Of course, Grietje Janssen and her husband were displeased at the studied slight and made some 


\section{Ennetje Fans, Hew Dork}

ugly remarks about the way in which the Dominie's wife displayed her shapely ankles. This came into court and Jacob Corlear had to testify that he was in the blacksmith shop when Mrs. Bogardus passed and saw her put her hand to her side and lift her skirt to avoid the mud of the street. Of course, the indignant woman had no trouble in proving that her care was to preserve the new clothes of her wedding outfit and not to show her ankle, and Grietje Janssen was compelled to retract her words publicly and to "throw something into the poor box."

Another story illustrative of the times tells of an incident that occurred at the wedding in June, I642, of Sara Roelof, Annetje's eldest daughter, to Dr. Hans Kierstede. "The wedding feast was celebrated with much jollity at the house of the bride's stepfather, and Director Kieft made a plot with the Dominie to turn the festivity to account for the service of the community. Religious services on Manhattan were first held in the loft of a horse mill; later, a plain structure was erected and dedicated to divine service, but the good citizens complained that travellers from Boston and Plymouth way called this building but little better than a 


\section{I76 Dioneer SMotbers of America}

barn. In New England, the very first activity in a new settlement was to erect a church; was it not a shame that New Netherland was so backward? So at the wedding, according to Captain de Vries, when the third or fourth round of drinking was reached, the Directcr produced a subscription paper for a fund to erect a new church. Kieft headed it with a liberal donation and the convivial guests, each with a light head, subscribed at a handsome rate, and, although when their senses came back some heartily repented their liberality, they were obliged to pay.

Dr. Kierstede became almost as prominent a character in the Colony as was Dominie Bogardus or the Director. He was under salary from the West India Company and the Company presented him with a piece of land on the bank of the East River near the fort where a house was erected for him. The fashion of the time demanded that the Doctor and the Dominie, no less than the Governor, should wear as insignia of their positions peculiarly cut coats, and pictures are still extant which represent the Director in a broad-tailed black coat with enormous cuffs and dainty lace frills at the 


\section{Annetje Fans, IAew Work}

sleeves and throat, dark small-clothes, silk stockings, great gold buckles on his squaretoed shoes, and bearing a heavy gold-headed ebony cane.

Katrina, the second daughter of Annetje Jans, married Johannes Peterse Van Brough, or Brugh, a young merchant who had come over as a commissary for the West India Company, and rose rapidly to a position of importance in the affairs of the Colony. He built himself a large and commodious house on what is now Pearl Street, near the corner of William. It was the son of Katrina Van Brugh's son, Peter Van Brugh, who became the father of Catharine Van Brugh, mother of Philip Livingston, "the Signer." Fytje, the third daughter, became, as we have seen, the wife of Peter Hartgers, a magistrate of Beverwijck, the Patroon's village.

The Dutch housewife, as we find her in the early years of the seventeenth century, was a most capable woman. On her judgment, prudence, and foresight depended largely the comfort, health, and welfare of her family. With her own hands or under her direct supervision was planted the kitchen garden, from which 


\section{I78 Dioneer Mothers of America}

came the vegetables that entered so largely into their family diet at a time when people in England were dying of scurvy by the hundreds, for the want of vegetable food. From this same garden, she culled herbs and simples and distilled and concocted medicaments and essences and perfumes. All the cooking was done directly under her supervision and no hand than her own was trusted with the preparation of the fruit preserves, pickles and condiments, and the pastry. Her daughters or maids, under her instruction, carded, spun, and wove the woollen goods that went into the clothing of the good man or of the children, but it was her hand alone that spun the fine thread from flax of her own garden for linen shirts, towels, and sheets. Occupying a place of so much importance in the household, it is no wonder that the Dutch women exercised the strong influence they did in the affairs of the Colony. One instance of this "influence" is shown in the official records. The wives of most of the traders, officials, and other prominent men of the Colony brought their maids, when they came over. But there were a number of men who came over without wives and not a few of the buxom maids were wooed 


\section{Annetje Fans, Nhew Work}

and won long ere their contracts expired. In a record, dated Monday, September I5, I653, Hans Fromer demanded that "Mme. Anna Van der Donck shall give lawful reason why she forbid the bond of matrimony between him and Maeyken Huybertsen." Guysbert Van der Donck appeared for his mother before the burgomasters and submitted the contract between Madame Van der Donck and her maid, which provided that, for free passage to America and her keep, the maid was to serve her for a stated number of years. The soft-hearted old burgomasters and schepen released the maid from her service and that of course encouraged all the other maids in the Colony to rebel. Madame Judith Varleth was compelled by the authorities to release her maid from her bonds and to pay her for the services already rendered. Then it was that the good old house vrouwen rebelled at the decrees of the burgomasters and the storm did not subside until they had made arrangements for another importation of maids from Holland who should be bound to serve their time out, which agreements, the councillors pledged their wives and women constituents, should not be abrogated. 
The good wives of Manhattan missed their market day as they missed a great many other things of the home country, and as this was one that could be got by working, they worked. The women united in a petition to the councillors to arrange for a market, where they might gather at stated intervals, to buy or sell their butter, poultry, eggs, feathers, flax, linen, linseywoolsey, etc. An order was issued September I2, I656, commanding that Saturday be kept as a market day and that the sale should be held in the burgh, "on the strand, near the house of Master Hans Kierstede." All the neighbouring farmers and their wives were invited to attend and exchange their products for sewant and wampum, the legalised currency of the Colony. The Indians were also urged to bring their simple wares and these were bought freely by the colonists. The women had become pretty well acquainted with the wild menschen. Madame Kierstede, in particular, became their trusted friend and it was largely through her encouragement that the savages were induced to enter the walls to barter their wares. She had a large shed erected in her own back yard, and under its shelter there were generally 


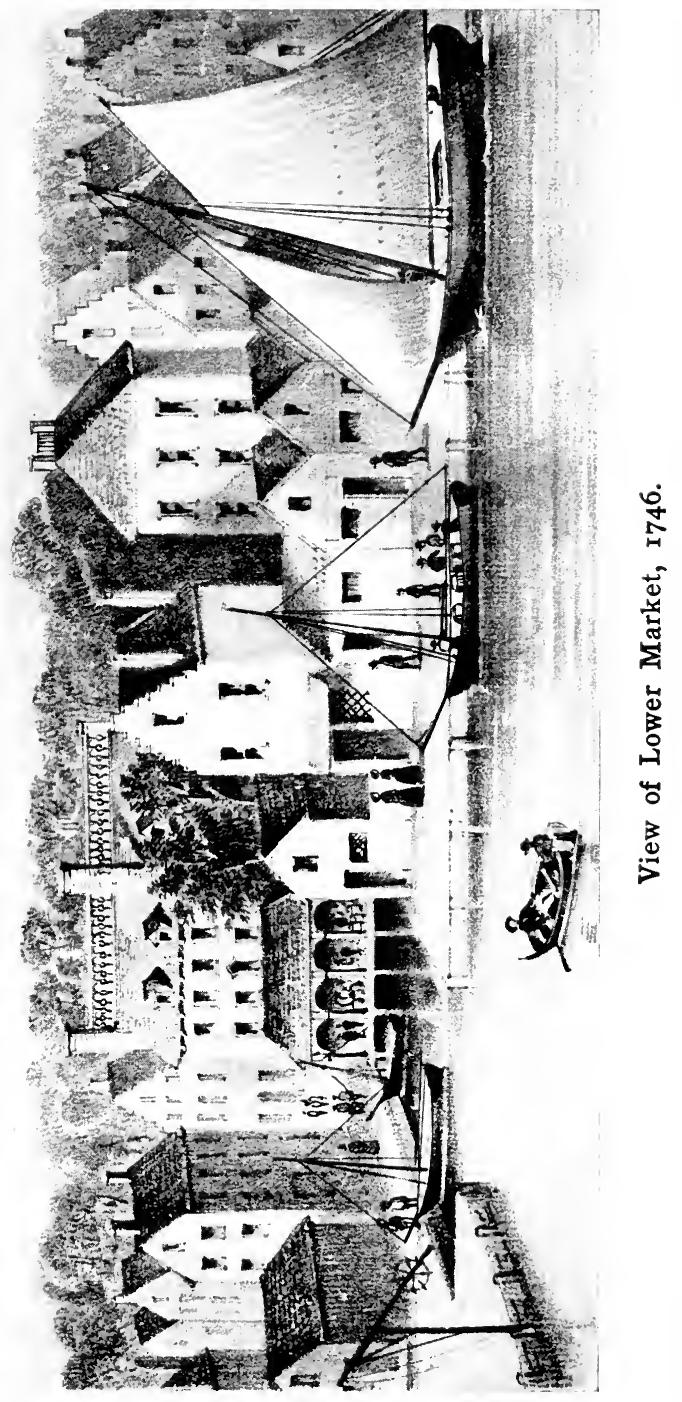





\section{Annetje Fans, Mew Work}

to be found a number of squaws who came and went as if in their own village, and made their baskets and brooms, drilled and strung their wampum, and wove cloth after the manner of their people, and on market days disposed of their products readily. Other Indians than those of Manhattan were attracted in this way, and a number from Manhattan and some from across the Hudson showed their gratitude by presenting Madame Kierstede with a considerable tract of land on the Hackensack River.

Annetje Jans's younger sister, Marritje, was married three times. Her daughter by her first husband, Tymen the carpenter, was married later in life to Jacob Leisler, the pig-headed patriot whom Governor Sloughter when in his cups, caused to be hanged. The Governor is said to have repented when he was sober. Her third husband was Govert Lockermans, a Dutch gentleman who came to America shortly after its first settlement. The Lockermans were an important family in the earlier history of New York. There were two brothers and one sister, left orphans in Holland, who determined to emigrate together to the New World. At least the sister did and she, being 


\section{84 Pioneer SilDothers of America}

the dominant character in the family, as was the case in so many Dutch families of that day, led her brothers to accompany her. The sister, Annetje Lockermans, was betrothed to Oloff Stevense Van Cortlandt, who was captain of a military company that came over to the new country in 1637. She followed her lover, as had been arranged, and brought her brothers with her. The pair were wed upon her arrival in February, 1642. Captain Van Cortlandt at once began building a home for his bride. The house was of imported, glazed brick, with a roof sloping with the gable end to the street; also the roof was built in steps so that the chimneys were easily accessible from the outside. Madame Van Cortlandt fitted up her house with furniture which she brought from Holland as her dower. Mrs. Van Rensselaer says: "This house of the Van Cortlandts became one of the centres of the petticoat government that so often controlled the affairs of the Colony and overturned the best laid plans of the officials, who would have scorned to acknowledge the influence that Madame Van Cortlandt and Madame Bogardus possessed by reason of their dominant characters and family connections." 


\section{Annetje Fans, Mew Work}

Captain Van Cortlandt gave up his military commission in I648, at the instance of his wife, and built a brewery near the fort, on Brower Street, one of the lanes running between Broad Street and Whitehall. Like all the streets and roads of the little burgh, it was simply a dirt road without even a sidewalk. Naturally the heavy traffic of the brewery waggons in wet weather turned the street into a mud hole, dirty and foul-smelling, and in dry weather almost as deep with dust, which was thrown up in clouds. This was most offensive to so fastidious a housekeeper as Madame Van Cortlandt is known to have been, but her remonstrances and scoldings were met with the good-natured laugh that tolerant and indolent husbands and village officials have from time immemorial adopted as a defence. Finally, she rebelled and had her servants lay a covering of round stones (cobble) from one end of the street to the other. It was the first paved street in America and people from all the Dutch settlements came to see the "stone street" as they called it, and as it is called to this day. Madame Van Cortlandt was to live to see one of her daughters the wife of Jeremias Van Rensselaer, Patroon of Rensse- 
laerwyck, and another the wife of Brant Schuyler and mother of General Philip Schuyler, while her son Stephanus founded the Manor of Van Cortlandt.

Govert Lockermans, who was led to emigrate to America by his sister, when she came over to wed Captain Van Cortlandt, married a comely maid of his native city and brought her along. This bride, Arientje Jans, the daughter of a well-to-do family, bore him two daughters, Maria and Jannetje, and then died. Some time afterward he married Marritje, the widowed sister of Annetje Jans Bogardus, who bore him one son and "was a tender mother to his two orphan girls "

Margaret Hardenbroeck was another of the early Dutch women of thrifty habit and proud spirit. She was married to Captain Peter de Vries, a ship-owner, and came with her husband to America, where he tried to found a settlement on Staten Island, having purchased manorial rights from the West India Company. He was unsuccessful as a coloniser and the grant reverted to the Company about the time he died. His widow converted his property into money and invested it in ships which traded between 


\section{Annetje Gans, New Work}

the two countries, thus establishing what was probably the first line of packets that crossed the Atlantic During one of her early voyages, Madame de Vries became acquainted with one of her passengers, Frederick Phillipse, a young trader who was carrying a large stock of furs to Europe; their acquaintance ripened into love and they were married in 1662 . The thrift and business ability of the two brought them the wealth with which they bought great tracts of land in the New Netherlands which were subsequently created a manor, "with grants of fisheries, mining, hunting, and tenorial rights," under the English rule. The Phillipse manor lay on the east side of the Hudson, with a manorhouse which stood on the site of the present city of Yonkers. The family also owned a house on Manhattan Island, close to the home of the Van Cortlandts on Stone Street, as well as other valuable properties that remained in the family for more than a century.

Annetje Lockermans was not the only plump and rosy daughter of the Netherlands to follow a lover across the seas to the land of the "wild men." Cornelia Lubbetse, in her native city of New Amsterdam, fell in love with the son of a 
French refugee, Johannes de Peyster, who had received his education there, and, acting on the advice of a friend of his father's, the Patroon Van Rensselaer, he determined to come to the New Netherlands and establish a mercantile business. The young lady followed him, as had been arranged, accompanied by her two brothers, and they were married in December, I65I. Heer de Peyster had already provided a comfortable home for his bride, on Store Street (no longer existing). Their wedding was a notable function. The house was furnished with ponderous chairs and tables imported from Holland. The silver service is said to have been the finest in the Colony. This house soon proved too small for the use of a man of Heer de Peyster's prominence and hospitality, and he built a mansion on Broad Street which was at the time the most commodious in town. De Peyster came in time to be not only very wealthy, but one of the most trusted burghers. His eldest son, "der Heer" Abraham de Peyster, early began to take his place as a prominent man of affairs. There were two daughters, the youngest of whom never married, her lover having been killed by the Indians. Maria, the eldest 


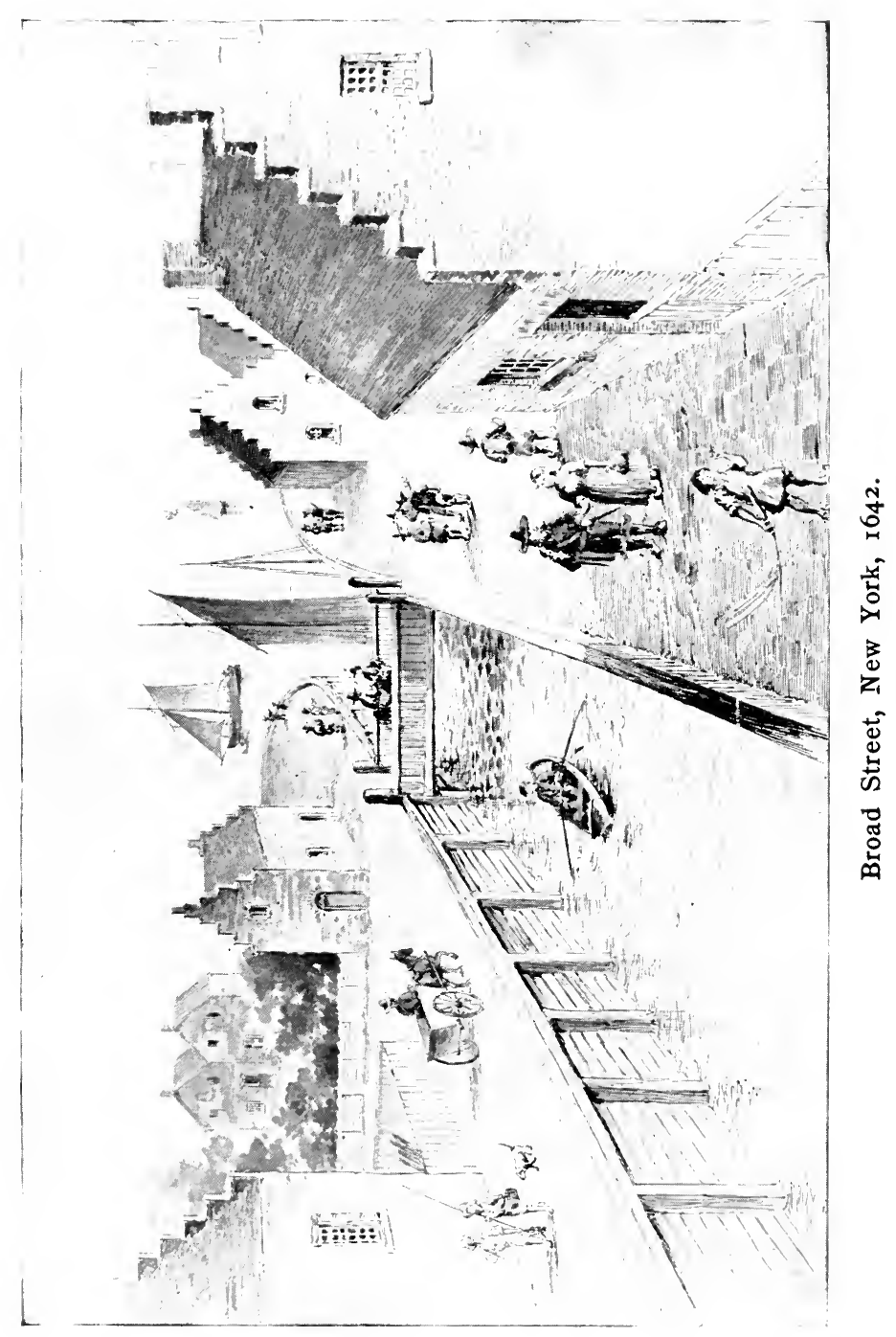





\section{Ennetje Jans, Whew Work}

daughter, married Paulus Schrick, a young man living in Hartford, and well-to-do in his own right. He was son of a merchant with a rich trade between New Amsterdam, Connecticut, and Virginia. The match was highly pleasing to the parents, and young Schrick is said to have made a settlement that caused his bride to be one of the wealthiest women of New York. A truthful bit of society gossip of that day was to this effect: "The bride had been carefully trained by her mother and was one of the best spinners and weavers of the Colony. In consequence her great 'kos' (chest of drawers) was filled with beautiful linen, made and marked by her own deft fingers and tied in packages with coloured tape."

They were married in May, I686, and Schrick took up his residence in New York, building a large house on what is now about 67 and 69 Broad Street. Within a few months, Madame Schrick was left a widow by the untimely death of her husband, which seems to have provoked general sorrow in the community, as a brief note in the ancient church register is evidence.

The young widow did not shirk the responsibility thrown upon her. She might have sold 


\section{Dioneer Motbers of America}

the business at an advantage and retired with a fortune. But this was not the decision for a girl who had come to her husband with a "kos" full of linen of her own spinning, weaving, and bleaching. She continued to carry on her husband's business in her own name and with great success. In I688, she married John Spratt, a young Scotchman who had emigrated to America eight years before and had come to be highly enough regarded to have received the appointment of Dock Ward, a position of considerable responsibility. The marriage seems to have been a successful one and their home was the centre of interest in the Colony. Mrs. Spratt was related to about all the most prominent persons on the island and they naturally rallied to her house. It was not only a social centre but also came to be the political centre. John Spratt became Speaker of the Provincial Assembly and an adherent of Jacob Leisler, but the prominence of his wife among the members of the aristocratic opponents of that unfortunate leader and her sound judgment kept him from going far enough to get him in trouble. He died in 1696 , leaving his widow with four children. Two years later she married David Provoost, a 


\section{Ennetje Fans, New Work}

wealthy widower of high reputation, whose grandfather had been one of Manhattan's earliest settlers.

The youngest daughter of John Spratt and Marie de Peyster, "Polly" Spratt, was reared by her grandmother de Peyster. She was a bright, vivacious girl, a natural leader among the young people, and as headstrong as she was beautiful. She was married in I7 I to Samuel Provoost, a younger brother of her stepfather and a wealthy merchant. She entered actively into his business, having had the usual Dutch girl's training in practical affairs, and soon showed the capacity for business matters that she had inherited from her mother and grandmother, and took a large share in the management of her husband's importations and correspondence. It was well that she did, as Samuel Provoost died in $17 \mathrm{I} 6$ or thereabouts and the big importing business that he had built up fell entirely to her. The business continued to thrive and she built a row of offices in front of her house and directly on the street, with a large store on one side. Sidewalks were still unknown in the town, and she tried to get the council to make some improvements on her street, but they failed to re- 


\section{I94 Dioneer SMotberg of Emerica}

spond, as they had when Madame Van Cortlandt, her grandmother's friend, wanted Brower Street paved with cobblestone. Then Madame Provoost laid flagstones along the sidewalk, the entire length of her property and beyond it, and up the streets on either side. It was the first sidewalk laid in New York and proved a great advertisement, and led much trade to her store as well as to the building of many new sidewalks. But business did not entirely engross the time of the young widow, and Polly Provoost was no less popular as a hostess with the best people of the town, or as a social leader, than had been Polly Spratt with the little band of young folks whom she led in the skating and coasting parties years before. Her house on Broad Street stood opposite Marketfield Street, which was dubbed "Petticoat Lane," as it led to the acknowledged arbiter of social affairs, as well as one having no small influence in the commercial and business affairs of the community, and even suspected of helping to shape in no small degree much of its political policy.

In June, I72I, the widow Provoost was married to James Alexander, a young Scotchman who had come into the Colony a few 


\section{Ennetje Jans, Mlew Work}

years before. $\mathrm{He}$ was a civil engineer and a man of broad education. He was one of a group of young Scotchmen who had espoused the cause of the young Pretender to the throne of Scotland and he was forced to flee the country. He was commissioned by his uncle Henry, the fifth Earl of Stirling, to act as his representative in America, where the Earl held large interest by a somewhat uncertain tenure. He came with letters from Scotch and English relatives to persons who had preceded him to America, including Robert Livingston, Cadwalader Colden, and the family of John Spratt. Alexander was accompanied by William Smith, a young Englishman of education and brilliant attainments. Alexander found ready employment for his services as civil engineer, and within four years he was appointed as deputy clerk of the council. Very soon after arriving here, he took up the study of law and, combining the two professions, rose rapidly to eminence in the Colony. He was appointed Surveyor-General of West Jersey, an office which he held for the remainder of his life, and was commissioned a member of the King's Council for the Province of New York, and also for New Jersey. He also filled 


\section{Dioneer Mothers of America}

the office of Attorney-General for New York and was a member of Assembly for the city of New York. The young bride opened an office for her husband alongside her counting-room and continued to control and direct her own large business. Several children were born to Mr. and Mrs. Alexander, one of whom was a son born in I725, who received the name of William. Fifty years later that young man was to be known as Lord Stirling, as well as General Alexander, a trusted friend of George Washington and an ardent supporter of the American cause. He married Sarah Livingston, daughter of Philip Livingston, lord of the manor, and a great-granddaughter of Annetje Jans.

Cornelia Lubbetse de Peyster, the venerable grandmother of Mrs. Alexander, died in 1725 at the ripe age of ninety-two years, and in her death passed away the last of that group of sturdy, steadfast Dutch women who for nearly a century had been so dominant a factor in the life of the city: Annetje Jans and her comely sister Marritje, daughters of Tryntje Jonas, the midwife; handsome Arientje Jans, who crossed the seas the bride of Govert Lockermans; energetic Annetje Lockermans, who left her home 


\section{Annetje Fans, Hew Work}

to follow the fortunes of Captain Orloff Van Cortlandt and become the mother-in-law of the Patroon of Rensselaerwyck; Katrina Van Brough, who married William Beekman, the trusted friend of Governor Stuyvesant and his wife Judith; and their sister, the accomplished and gracious Anna Stuyvesant, the widow of Samuel Bayard; and Margaret Hardenbroeck whose thrift and ambition had made her lady of the great Phillipse manor established by her husband, the fur dealer, on the banks of the Hudsonall were gone, gathered to their fathers. But their influence continued and still continues-a heritage of American womanhood. The strength of mind and character and other sterling qualities, as well as their devotion to housewifely attainments, were as necessary to the development of that womanhood as was the stern selfrepression and austere piety of the Puritan New England strain, or the lighter and gentler characteristics of the Cavalier blood of the Southern plantations.

\section{NOTES TO CHAPTER IV}

I Janse, contracted form of Janssen, the feminine of which was often used as "Jans." Her father's name had been Jonas Webber, but upon his death the mother dropped the name of Webber and was known as Tryntje Jonas. There is a tradition extant that Annetje 


\section{Dioneer Motbers of America}

Jans and her sister were really grandchildren of William IV., Prince of Orange, but there seems to be no proof that they were other than respectiable peasant people.

a Catalina de Trice was the wife of Joris Rapelje, and the mother of Sarah Rapelje, the first white child born in New Netherland, but as the babe was born at Fort Orange in 1624, the Rapeljes must have moved up the river shortly after they came to Manhattan. In I626, the pair with the infant Sarah came back to Manhattan and lived in a house on Pearl Street adjoining the south side of the Fort for twenty-two years, when he sold his house and lot and retired to a farm which he owned near Wallabout. Sarah Rapelje was married in $\mathbf{I} 639$ to Hans Hansen Bergen, and from them come the Bergens of Long Island and New Jersey. He was of Norwegian birth, and had come to New Amsterdam from Holland in I633, and dying in $165+$, his widow became the wife of Thensis Gysbert Bogaert, by whom she had seven children. She died about 1685 , and her descendants include the Bergens, Bogaerts, Polhemuses, and a number of other of the families notable in the history of Brooklyn and Long Island. Catalina de Trice Rapelje, long known as the "Mother of New York," made affidavit before William Morris, Justice of the Peace, October, I688, at her home in"Wallabout, that she was then eighty-three years old, that on the arrival of the Unity-the first ship sent over by the West India Company-two families and six men were sent to Hartford River, two families and eight men to the Delaware River, eight men were left in Manhattan, and the rest, eighteen families, went on up to Fort Orange. She lived there three years and then came back to Manhattan. 
"】

May ask, incredulous; " and to what good end?

Why drag again into the light of day

The errors of an age long since passed away?"

I answer: "For the lesson that they teach:

The tolerance of opinion and of speech.

Hope, Faith, and Charity remain,--these three:

And greatest of them all is Charity."

Longfellow. 



\section{Chapter V}

\section{Ann நbutcbinson}

America's first club woman-She was excommunicated by her church, and exiled by Massachusetts Bay Colony for heresy in 1638-Removed with her family to Rhode Island where her husband died a magistrate-She and her youngest children murdered by Indians at Pelham Manor in I644-A descendant, Thomas Hutchinson, was the last royal Governor of Massachusetts-Lady Deborah Moody, a religious exile who came to Long Island-The witchcraft craze of Salem.

T $N$ the annals of great cities, as in the lives of strong men, there are sometimes 1 found pages, blistered and blackened by deeds done when passion and prejudice have blinded justice and charity was forgotten. Such was the religious fanaticism that one bleak March day in 1638 drove from Boston Ann Hutchinson, with a babe at her breast, a blot on the fair fame of the Colony and clergy as foul as the murder of the Quakers twenty years later, or the witchcraft atrocities of Salem in 1698.

Ann Hutchinson, said to have been a cousin 


\section{2}

\section{Pioneer Mothers of America}

of the poet Dryden, was the daughter of Rev. Francis Marbury, ${ }^{1}$ a noted preacher of Lincolnshire, England, and was born in 1590 . At the age of twenty-two, she was married to William Hutchinson, a well-to-do country gentleman, and a mild-mannered, kindly man of whom the records say but little. He appears to have had no lack of physical courage and to have been a kind and loving husband and father. John Winthrop writes of him, in his diary, as a man of "a very mild temper and weak parts," but Governor Winthrop, eminent as was his station, was not one to whom we can go for unbiassed judgment. The mere fact that Mr. Hutchinson was largely guided in religious matters by his wife was no more than can be said of a number of others, including the noble young Governor of the Colony, Sir Harry Vane, Magistrate William Coddington, afterwards Governor of Rhode Island, John Underhill the soldier, and Ann's brother-in-law the Rev. John Wheelwright.

Winthrop describes Mistress Hutchinson as a woman of "bold spirit" and "ready wit." She with her husband had sat under the ministration of Rev. John Cotton as vicar of St. Botolph in 


\section{Ann Ibutchinson}

that Boston, Lincolnshire, which gave name to the Puritan town on the New England coast. When John Cotton became a non-conformist and crossed to America to find a home, he left behind no stauncher friends and admirers than Mistress Hutchinson and her husband. Not long after, they too came to New England, and the woman frankly admitted that she had crossed the sea solely to continue under his preaching.

Some fine distinctions were drawn in those times in religious matters, - - so fine, that it is hard to grasp them in these later days. Anyway it was said that on the good ship Griffith, which bore Mistress Hutchinson and her family to the shores of Massachusetts, she shocked some of her fellow passengers by expressing "opinions" and claiming "revelations." One Rev. Mr. Symmes was especially exercised and soon after landing there began to be whispers throughout the Colony hinting at heresy on the part of Mistress Hutchinson. It was not much, but enough at that period to prevent the Boston church from accepting her as a member, though Mr. Hutchinson was promptly received. All this, however, seems to have in no wise lessened 


\section{Dioncer Mothers of America}

the woman's interest in churchly affairs and after a few months she was received into membership. She began to be accepted also as a valuable acquisition to the society of the town. She was intelligent, kindly, charitable, as well as courageous and outspoken. But ever she was critical and always with a power of sarcasm and of logical reasoning that picked flaws in the phariseeism, the sanctimonious pretence and hypocrisy that were more or less unconsciously fostered by the theology that these austere, self-justifying men had fashioned from the teachings of the lowly Nazarene. She said what she thought of their teachings, and what she thought was not always complimentary. The Rev. Mr. Wilson was the minister of the Boston church and Rev. John Cotton, the teacher. Mistress Hutchinson did not like either the personality or the theology of $\mathrm{Mr}$. Wilson, and to show her dislike she on more than one occasion arose and left the church when he began his sermon. Then the women of the town began dropping into the home of Mistress Hutchinson, a plain frame building standing at what was later to be Washington and School Streets, and upon which was built "The Old 


\section{Ann Ibutchinson}

Bookstore," for many years a landmark of Boston. They came to discuss the sermon and to exchange the churchly gossip of the day. The lives of the good women of that period were not so full of incident as in ours, and these religious arguments and dissertations, for so great was the predominance of Mistress Hutchinson that it is altogether probable that she did most of the talking, became highly popular. Soon it became a regular thing for the women to gather twice a week at Mistress Hutchinson's as at a club. It was at one of these meetings, we are told, that the good woman, "with hands firmly clasped in her lap, head thrown back, and eyes focussed on one face and then another, made the bold remark, in comparing her own minister, Rev. John Cotton, with the other ministers of Boston:

"The difference between Mr. Cotton and the other ministers of this colony is as wide as the distance between heaven and hell: for he preaches not a covenant of works, but of grace, and they, having not a seal of the spirit, are no able ministers of the New Testament."

Remember that this was in a community and a period when church membership was a test 


\section{Dioneer SMothers of America}

of good citizenship and social standing and ministers were esteemed beyond criticism, and the iconoclastic spirit of Mistress Hutchinson's bold words can be better understood.

Anyway, the woman was becoming a vogue. Nearly all the women in the Colony were glad to come to her club-the first woman's club in America,-pleased with an opportunity to get together and to talk freely about the one matter that was foremost in their barren lives. These gatherings constituted one of the few breaks in the monotony of a community where there were no libraries, no social meetings, no newspapers, nor magazines. But however pleasing this was to the women, it was anything but satisfactory to the ministers, and soon there came a whispering through the Colony that Mistress Hutchinson was a "breeder of heresies" and a "dangerous woman." It was undoubtedly true that there was growing up in the Colony a spirit of criticism, and it was not long before Boston church was split in two factions, one upholding Mr. Wilson and the other siding with Mistress Hutchinson. Lieut.-Governor John Winthrop championed the cause of the pastor, mainly because he thought it best for the 


\section{Fnn \butcbingon}

well-being of the colony; and such others of the congregation as were of the austere stripe of Winthrop and Wilson sided with the Lieutenant-Governor. Mistress Hutchinson was not without friends, however; her teacher and friend, Rev. John Cotton, was at first her supporter, as was the young Governor Sir Harry Vane, her brother-in-law Rev. John Wheelwright, and a majority of the congregation of the Boston church. The division spread. The churches outside of Boston supported their ministers, who in the main held with Rev. Mr. Wilson and Lieutenant-Governor Winthrop, thus making it a contest of the suburbs against Boston. In I637, John Winthrop, the father of Massachusetts, and defender of the clergy and of the old order, was chosen Governor, in the place of progressive and broadminded Governor Vane. The success of the ministerial faction was a sore disappointment to Sir Harry Vane, and a few months later he sailed for England-always to remain a staunch friend to the Colonies and to the cause of human rights and human progress for which he was ultimately to give his life on the scaffold.

The clerical party were now in full control. 


\section{Dioneer Motbers of Elmerica}

In the General Court they were in a large majority, and the course they laid was as autocratic as any that ever harried themselves or their forebears in the land across the sea. The Rev. John Wheelwright, minister of the church of Braintree, was banished from the Colony for "sedition and contempt." Hardly had he left his home for a lodge in the wilderness, when Mistress Hutchinson was summoned before the court upon charges and her trial set down for November I 7 th at Cambridge. Before her trial, several other of her friends and supporters were fined, reprimanded, or banished from the Colony.

It was a grimly determined body that Ann Hutchinson faced that chill November day, as she entered the little log meeting-house of New Towne (now Cambridge). It was crowded with spectators. They had come on foot, on horseback, and in farm waggons. Governor Winthrop sat at the head of the table, his Puritan ruff no stiffer than his austere countenance. On the details of the trial we need not dwell. So trivial were the charges, so deeply metaphysical was the hair-splitting question of faith upon which they differed, that, but for the pathos of that one frail, bright-eyed little woman, alone 


\section{Enn Thutchinson}

and almost friendless facing her sanctimonious persecutors, the proceedings would have been laughable. The ministers testified against her, but the testimony showed little but the wounded vanity that had come from her sharp-tongued criticisms of their prosy sermons. Rev. John Cotton spoke eloquently in her defence and William Coddington, her one friendly judge, thought that the woman was sure to be freed from her persecutors. Then the woman spoke of the "revelations" she had received, closing with:

"I fear none but the great Jehovah which hath foretold me these things and I do verily believe that he will deliver me out of your hands. Therefore take heed how you proceed against me; for I know that for this you go about to do me, God will ruin you and your posterity and the whole state."

Then came the explosion of clerical wrath. In the eyes of her Puritan judges belief in personal revelations was a sin, worse than blasphemy. It was heresy, and court and clergy hurled denunciations and invectives at the unhappy woman. As the storm subsided, Winthrop arose, stern, unyielding, and unsympathetic: 


\section{Io Dioncer SDothers of America}

"It is the opinion of the court, that for this troublesomeness of her spirit and for the dangers of her cause, this woman, Mistress Ann Hutchinson, be banished from the Colony."

But three persons in all the court showed evidence of their sympathy.

"Mistress Hutchinson," continued the Governor, and his voice was cold and hard as his mien, "hear now the sentence of this court: It is that you are banished out of our jurisdiction, as being a woman not fit for our society, and you are to be imprisoned until the court shall send you away."

As this sentence stands on the records of Massachusetts Bay Colony it reads: "Mrs. Hutchinson being convicted for traducing the ministers, she declared voluntarily the revelations for her ground, and that she would be delivered, and the court ruined and their posterity; and thereupon she was banished, and meanwhile was committed to Mr. Joseph Weld, until the court should dispose of her."

None of her friends except her own family was permitted to see her during her imprisonment, lest "she spread heresy." But the elders and ministers came daily to question her, 


\section{F̂n Ibutcbinson}

to argue, to suggest and to lead her on. Naturally the woman was lonesome, anxious, agitated, and talked more than she should. Moreover, she did not realise that a trap was being laid for her by these godly men. Even the man upon whom she had relied most, Rev. John Cotton, found that he was on the unpopular side and shifted his ground. From being her teacher and spiritual guide, he became one of the most vigorous persecutors of her particular brand of "heresy." The ministers did relent enough to decide that the woman need not be driven into the wilderness until the milder weather of spring came. But they did decide that she must face another ordeal, and she suddenly found herself called before her own church to answer charges of "gross errors to the number of thirty or thereabouts." She must answer these charges or be excommunicated. There were few friends to meet her when she came to the trial. Her husband and brother-in-law were away, seeking places of refuge against the coming exile.

"By what precept of holy writ did the elders of the church come to me in my place of confinement, pretending that they sought light when 


\section{I2 Dionecr SDothers of Elmerica}

in reality they came to intrap and betray me?" she demanded indignantly when she had taken the place assigned to her. She declared that the twenty-nine "gross errors" with which she was charged were really the result of her unjust imprisonment, and defended herself with great spirit and, as the old chronicles tell, "returned forward speeches to some who spoke to her."

From ten o'clock in the morning until the shades of night, were falling there was a war of words-assertions and denials, accusations, biblical quotations, and theological quibbling until the people were tired and hungry, and yet only four of the twenty-nine "gross errors" were gone over. And ever the woman had met argument with argument, quotation with quotation, and spiteful accusation with calm denial. She had outtalked the ministers and bid fair to tire them out. Then they whispered among themselves and decided to administer a public reprimand. Mrs. Hutchinson's son, a handsome intelligent young man, sprang to his feet in defence of his mother. His cheeks flamed and his eyes blazed but his tones and words were most respectful. ${ }^{2}$ Not so with her son-in-law who immediately followed. 


\section{Ann Thutchingon}

"My mother is not accused of any heinous act," he said, "but only of an opinion held by her upon which she desires information and light, rather than peremptorially to hold to it. I cannot therefore see why the church should yet proceed to admonish her."

"It is a grief to my spirit to see these two brethren question the proceedings of the church," said Elder Thomas Oliver, who then proposed that the two young men should be included in the reprimand decreed against their mother, "in order that the church might act in unison." It was so ordered and the Rev. John Cotton, the whilom friend and spiritual guide, made his own standing more secure by delivering the admonition to the unhappy woman and her sons, who by their filial act had, as he said, "torn the very bowels of their souls by hardening their mother in sin."

The woman was turned over to the care of Rev. John Cotton in the hope that he "might overcome her troublesome spirit." Here comes the only exhibition of weakness shown by Ann Hutchinson during her trial. The Rev. John Cotton prayed with the miserable woman and so worked upon her overwrought emotions that 


\section{Dioneer SDothers of America}

she actually appeared at the Boston church the following week and with bowed head and low tones recanted, and acknowledged her transgressions in not accepting as final the opinions of the ministers. But that was not enough. One after another of the elders and the ministers began to take up her previous statements made at different times and compel her to acknowledge their falsity. More hairsplitting arguments, hazy and undefinable, more dissertations and theological quibbles, but always acrimonious and ill-natured. Finally, after hours of the torture, Ann Hutchinson, goaded to madness by the pitiless mocking faces of her enemies, flamed up with the strongvoiced declaration: "My judgment is not altered though my expression alters!" Then again she was beset from every side. For many minutes the storm of invective, accusation, sarcastic reproach, and stinging innuendo raged. Only once did the woman speak: "Our teacher knows my judgment," she said, turning to Rev. John Cotton; "I never kept my judgment from him." But John Cotton had deserted her, and Parson Wilson, her greatest enemy, pronounced the sentence of excommunication. 


\section{Gnn Ibutchinson}

"Are ye all of one mind that our sister here be cast out?" he asked, and then after a pause which seemed to give general consent, he pronounced the sentence which has left an everlasting stain on the name of the colony.

"Thereupon, in the name of the Lord Jesus Christ and in the name of the church, I do not only pronounce you worthy to be cast out but I do cast you out; and in the name of Christ I do deliver you up to Satan, that you learn no more to blaspheme, to seduce, and to lie; and I do account you, from this time forth, to be a heathen and a publican, and so to be held by all the brothers and sisters of the congregation, and others; therefore, I command you, in the name of Christ Jesus, and of this church, to withdraw yourself as a leper out of this congregation."

A hush as of horror fell over the meeting as Mrs. Hutchinson arose to pass from the room. It was broken by the self-righteous tones of one who said: "May the Lord sanctify this unto you." The woman turned and faced the speaker.

"The Lord judges not as man judges," she said in calm tones. "Better be cast out of the church than deny Christ." So went Ann 


\section{Dioneer SDothers of America}

Hutchinson forth to gather her little family and depart for a new home in the unbroken wilderness, because she differed in belief, in some minor essentials concerning the fallibility of earthly ministers. But one friend-a woman -young, educated, and well born, had the courage to stand beside her in this her hour of humiliation, and it was upon the shoulder of Mary Dyer ${ }^{3}$ that she leaned as she passed from the room.

Her husband and family were staunch and loyal, and joined uncomplainingly in her exile, carrying only such of their earthly possessions as could be loaded on a pack-horse. They journeyed to Rhode Island where they were made welcome by Roger Williams. William Hutchinson was made a magistrate of the Colony in 1640 , which office he held at the time of his death in 1642 . His widow after his death gathered the remainder of her family, excepting her eldest son and daughter, and pushed west to the fringe of the Manhattan Colony, settling among the Dutch where Pelham Manor was to be later, and where "Hutchinson's Creek" and a little point of land, jutting into Long Island Sound, still called "Anne's Hook," 


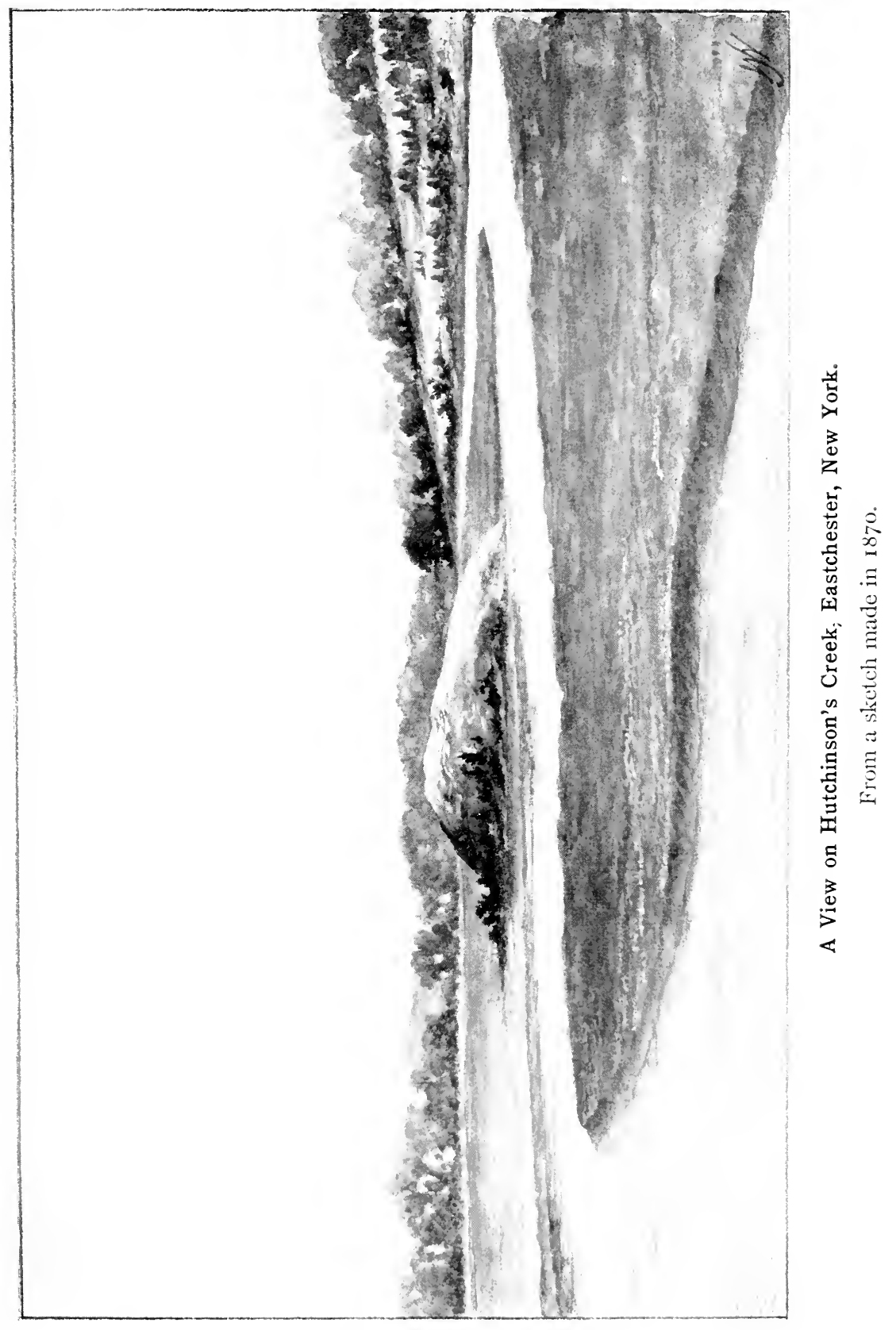





\section{Fnn Thutchingon}

remain to mark her memory. There she and all her family except one child, who was taken captive, were murdered by the Indians in August, I643.

\section{ANN HUTCHINSON'S EXILE.}

"Home, home-where 's my baby's home?

Here we seek, there we seek, my baby's home to find.

Come, come, come, my baby, come!

We found her home, we lost her home, and home is far behind.

Come, my baby, come!

Find my baby's home!"

The baby clings; the mother sings; the pony stumbles on;

The father leads the beast along the tangled, muddy way;

The boys and girls trail on behind; the sun will soon be gone,

And starlight bright will take again the place of sunny day.

"Home, home-where 's my baby's home?

Here we seek, there we seek, my baby's home to find.

Come, come, come, my baby, come!

We found her home, we lost her home, and home is far behind.

Come, my baby, come!

Find my baby's home!"

The sun goes down behind the lake; the night fog gathers chill,

The children's clothes are torn; and the children's feet are sore. 


\section{0 \\ Pioneer SDotbers of America}

"Keep on, my boys, keep on, my girls, till all have passed the hill;

Then ho, my girls, and ho, my boys, for fire and sleep once more!"

And all the time she sings to the baby on her breast: "Home, my darling; sleep, my darling; find a place to rest;

Who gives the fox a burrow will give my bird a nest.

Come, my baby, come!

Find my baby's home!"

He lifts the mother from the beast; the hemlock boughs they spread,

And make the baby's cradle sweet with fern leaves and with bays.

The baby and her mother are resting on their bed;

He strikes the flint, he blows the spark, and sets the twigs ablaze.

"Sleep, my child; sleep, my child! Baby find her rest, Here beneath the gracious skies, upon her father's breast;

Who gives the fox a burrow will give my bird her nest Come, come, with her mother, come! Home, home, find my baby's home!"

The guardian stars above the trees their loving vigil keep;

The cricket sings her lullaby, the whippoorwill his cheer.

The father knows his Father's arms are round them as they sleep;

The mother knows that in His arms her darling need not fear.

"Home, home, my baby's home is here;

With God we seek, with God we find the place for baby's rest. 


\section{Fnn butchinson}

Hist, my child; list, my child; angels guard us here. The God of heaven is here to make and keep my birdie's nest.

Home, home, here 's my baby's home!"

Edward Everett Hale.

\section{Lady Deborah Moody}

There was another English woman of gentle birth and breeding whom the narrowness and intolerance of clergy-ridden New England were to drive into the wilderness, within two years after the exile of Ann Hutchinson; this was the widow of Sir Henry Moody.

Lady Deborah Moody was a gentlewoman of wealth and refinement but of positive views on many subjects. She was a daughter of Walter Dunck, of Avesbury, England, and in 1625 married Sir Henry Moody of Garresden in Wiltshire, one of the baronets created by King James in I622. He died in 1632 leaving her one son. She was an ardent Baptist, and refused to pay taxes for the support of the established church, preferring to leave her native land and all the associations to which her position and wealth would entitle her, and to seek a home in the land which was pictured as a refuge for the oppressed and persecuted. 
Her company, which included a number of families from her estates in England, arrived in Boston in 1640 and soon purchased a large farm from John Humphrey, one of the original patentees. In less than two years, she found the settlement as intolerant as anything she had left behind, and she was finally expelled from her church in Salem because she refused to accept the doctrine of infant baptism. She moved to Long Island where she founded the town of Gravesend, building a strong house overlooking New York Bay and directly opposite the plantation of Margaret Hardenbroeck de Vries on Staten Island, with whom she soon established friendly relations, as she did also with Mrs. Anne Stuyvesant, who persuaded her husband to pay an official visit to the English woman and extend to her his governatorial protection. Governor Stuyvesant wrote of her: "Ladye Moodye, a very wise and anciently religious woman, but with very erroneous views in religious matters." When the Indians arose against the Dutch of New Amsterdam in 1643, at which time the family of Ann Hutchinson and a neighbour named Cornhill, were put to death, the Indians crossed the Sound, east of 


\section{Ann 历utcbinson}

Hell's Gate, and attacked Lady Moody's home, but were repulsed by her forty sturdy defenders. She lived in peace and content till the end of her life, much beloved by her Dutch neighbours of Wallabout.

\section{Witchcraft in Salem and Elsewhere}

Of a part with the excommunication of Ann Hutchinson by the church of Boston and her exile by the Bay Colony, was the persecution of the Quakers, by whipping, cropping of ears, piercing of tongues, and hanging in the early 'sixties, and the witchcraft persecutions which culminated in the Salem barbarities of 1692. All were born of the intolerance of the religious oligarchy set up by the Puritan ministers, who so absolutely dominated the affairs of the colony, secular as well as churchly, from the coming of John Endicott to the reaction that came after the vengeful Parris had led Salem and the county of Essex into the murder of nineteen persons by hanging and of one done to death by torture. As most of the victims were women, it is proper that we touch upon the story of their taking off, as a picture of one 


\section{Dioneer SDotbers of Elmerica}

phase of Colonial life highly important because of the influence it was to have in the disassociation of Church and State.

We must remember, however, that the belief in witchcraft was general at that time. The great legal authorities of England, Matthew Hale, Coke, and others, had gone on record as accepting it as a fact. It was a day in which people read their Bibles literally and the text from Exodus, "Thou shalt not suffer a witch to live," was taken as sufficient warrant for the execution of anyone proven guilty of witchcraft. We must remember also that the ministers, while in the main earnest and God-fearing men, walking in such light as was given them, yet shared in the weaknesses inherent to human nature, one of which is a love of power and an enmity against anyone or anything that would curtail that authority.

It has grown to be popular in these later days to attribute the witchcraft persecutions to some sort of mental epidemic that raged in the Massachusetts village of Salem for some months in I692. In fact, however, witches had been hanged before this in Charlestown, Dorchester, Springfield, Cambridge, and Hartford. The 


\section{Enn butcbingon}

first victim of witchcraft executed was Margaret Jones who was tried before Governor Winthrop and hanged. In 1656, Mistress Ann Hibbens, widow of a wealthy merchant of Boston, who had been a member of the Council of Assistants and at one time the Colony's Diplomatic Agent in England, was hanged on Boston Common. She was a sister of Deputy Governor Bellingham and a refined, educated woman of the highest social standing, but not entirely submissive to the domination of the ministers in spiritual matters. Her trial and execution took place under Governor Endicott.

In the village of Salem with its 1500 or 1600 inhabitants, the minister, Samuel Parris, in the year I69I, had trouble with some members of his congregation, and the division in the church had become so bitter and rancorous that the matter had gone before the General Court. A portion of the congregation wanted Parris removed and Rev. George Burroughs, a Harvard graduate and a kindly, sensible man who had already preached in Salem, put in his place. In February, Parris's little daughter, aged nine years, and his niece, Abigail Smith, eleven years old, began to act strangely, crawling under 
tables, assuming strange postures, and uttering strange cries, and at times appearing to go into convulsions. The family physician, Dr. Griggs, gave it as his grave and learned opinion that they were bewitched. A female servant, half Indian and half negro, was charged by her husband with having bewitched them. Parris scourged her until she confessed. Then came a gathering of ministers and a day of fasting and of prayer. The children were the most conspicuous persons in Salem. Parris demanded of Tituba, the servant, who had helped her in tormenting the children, and she told him that the Devil had appeared to her in the "form of a man in black, accompanied by a yellow bird," and that under threats from him she and Goody Osborn and Sarah Good had bewitched the girls. Goody Osborn was a bed-ridden old woman whose wits had gone astray from trouble and sickness, and Sarah Good, a friendless and homeless old creature. The first examination was held in the meeting-house in Salem before John Hawthorne, ancestor of the novelist, and Jonathan Corwin, as magistrates. The children told of pinchings by unseen fingers, of pins and needles thrust into them, from where they knew not. One 


\section{Ênn butcbingon}

told of being stabbed with a knife, the broken blade of which she exhibited. A young man interrupted to say that the broken blade came from his pocket-knife, and that he had broken it and thrown the blade away, in the presence of the girl. $\mathrm{He}$ was reprimanded by Parris, who was acting as prosecutor and register of the court, for disturbing the hearing, and the magistrates, after warning the little girls that they "must not tell lies," went on with the farcical examination. The servant was sent to Boston jail and the accused were locked up to await a formal trial. In the meantime, the girls were charging others with being witches: Rebecca Nurse, a woman of blameless life and much beloved of all save Parris whom she had opposed; then Sarah Cloyce and Elizabeth Proctor, all of whom had opposed Parris. Rev. George Burroughs counselled moderation and expressed the belief that the testimony was not conclusive, and he found himself under arrest as a suspect. Then Martha Corey, wife of an aged and stubborn farmer, Giles Corey, was accused, mainly because she had criticised the acts of Parris, and it was thought that the evidence of the old man might convict her. Within 


\section{Dioneer Motbers of Almerica}

a few months several hundred people in Salem, Andover, and Boston were arrested and locked up in jail. Governor Hutchinson, a historian of the time, says that "the only way to prevent being accused was to become an accuser."

Samuel Bradstreet, the Governor, decided that the evidence against the victims of Parris, none of whom had confessed, was not sufficient to warrant holding them for trial. At about that time, May, I692, came the new charter granted to the colony by William III., and with it the Governor Sir William Phipps and his deputy, William Stoughton, both of whom owed their appointment to Rev. Increase Mather and his son Cotton Mather, pastor of the North Church and soul and forefront of the persecution of witches. Immediately, a special court was instituted, with Stoughton as judge, and Wait, Winthrop, and Sewall as associates, and early in June the court opened session in Salem. No such thing as insufficient evidence now. Parris by this time had brought charges against nearly all those members of his congregation who had opposed him, and many others. Cotton Mather seems to have been general historian as well as general director of public opinion. It was 


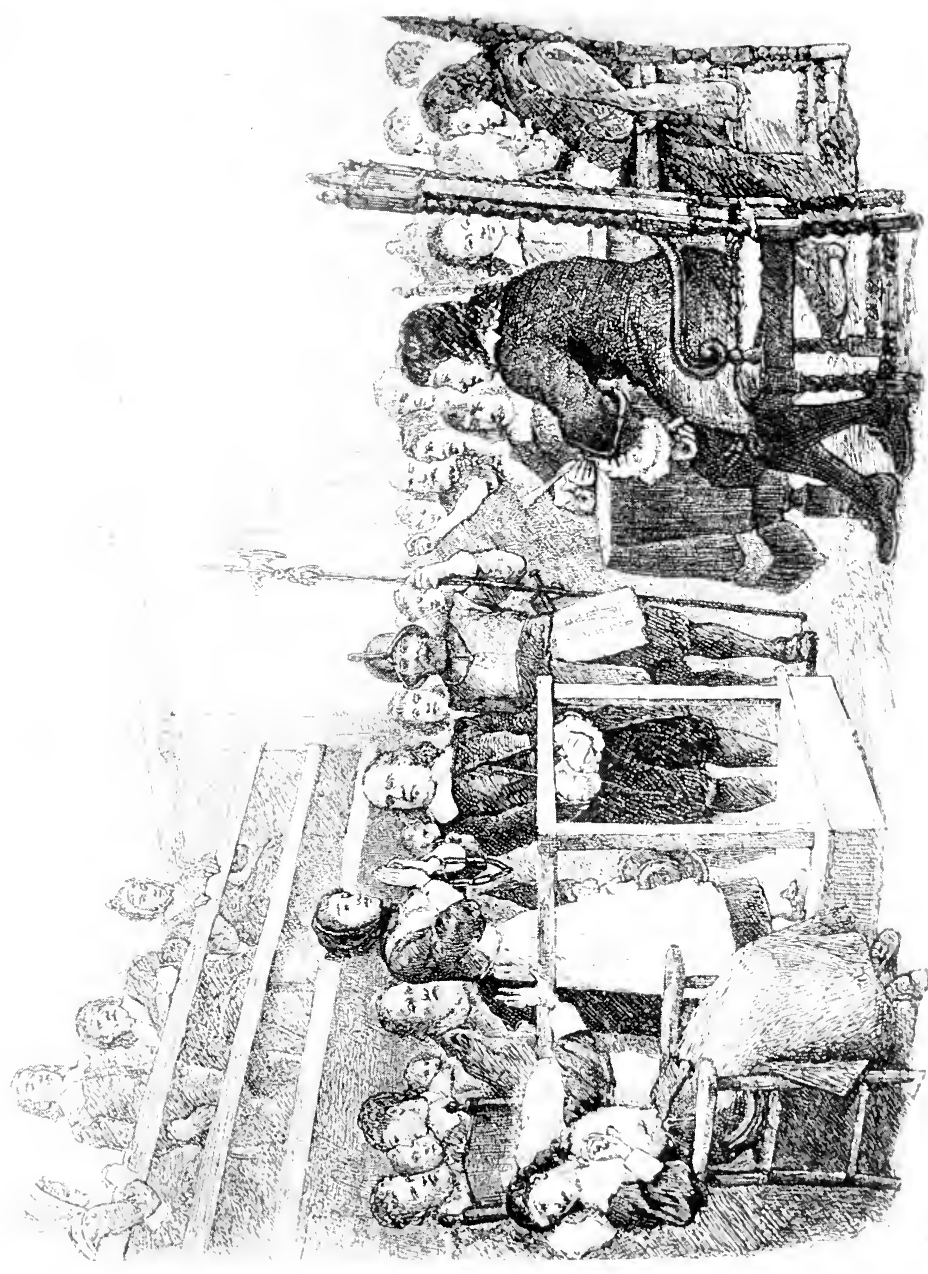

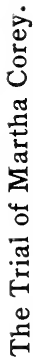




\section{ann tbutchingon}

Cotton Mather who had written that witches "were among the poor and vile and ragged beggars on earth," and one of the first cases taken up was that of Deliverance Hobbes, a poor old creature who, because she was old and friendless and bore a birthmark that must have been "the Devil's sign," was held responsible for some of the ills suffered by her neighbours. It was of her that Cotton Mather relates: "She gave one look towards the great and spacious meeting-house of Salem, and immediately a demon, invisibly entering the house, tore down a part of it." She was hanged on the tenth of June, protesting her innocence. Bridget Bishop, aged and decrepit, yet with some enemies, was found guilty and hanged. A flagrant case was that of the good Rebecca Nurse. She was generally beloved, and the jury could not agree until Stoughton practically directed their verdict. The Governor granted a reprieve, but "Parris, who had preached against her and prayed against her and had induced the 'afflicted' to witness against her and had caused her sisters to be imprisoned because of their natural sympathy," opposed the reprieve so successfully that the old woman, 
after being "dragged weeping in her chains to the meeting-house and excommunicated," was hanged with four other old women.

An old man named Jacobs was convicted on the testimony of his granddaughter. Conscience-stricken afterward she went before the judges and confessed the truth. She was held for trial, but the old man was hanged just the same. George Burroughs, the minister, who had denied that there was any such thing as witchcraft, in the current sense, went to his death with dignity, making an earnest and eloquent speech from the scaffold and closing by repeating the Lord's Prayer with great fervency. Rev. Cotton Mather, who watched the hanging from on horseback, harangued the crowd, cavilling at the ordination of Burroughs, insisting on his guilt, and asserting that the Devil sometimes assumed the appearance of an angel. Giles Corey, a highly respected farmer, eighty years old, whose rambling and wholly innocent testimony had been contorted and twisted to convict his wife, absolutely refused to answer questions, and even to plead "not guilty." This saved his property for his children, which would not have been the case had he been con- 


\section{Ann butcbingon}

victed of witchcraft after having pleaded "not guilty." Failing to force the old man to answer, the court condemned him to the torture of peine forte et dure, said to be the one instance of the application of this old English penalty in New England. According to law, the old man was laid on his back with a timber on top of him, weighted almost to the crushing point. Every other day he was given a drink of water and on alternate days a morsel of bread until death ended his sufferings. Three days after the death of Corey, eight persons were hanged on Gallows Hill, and that ended the tragedy.

Accusations were still pouring in. The jails were full, and one hundred and fifty persons awaited trial. In October, the representatives of the colony assembled, and a delegation from the people of Andover, led by their minister, appeared with a remonstrance against the doings of the witch tribunals. There is no record of the discussions that ensued, and we only know that the General Court ordered, by bill, a convocation of ministers to define better the crime of witchcraft, and its more orderly consideration. The General Court also abrogated the special court and established a new tribunal, but delayed 


\section{Dioneer Mothers of America}

its opening until January of the following year. This gave time for thought, and when next the court sat, the grand jury threw out more than half the cases brought before them, and of the twenty-six cases considered, the evidence, though the same as in other cases where convictions had been found before, now resulted only in acquittals. The witch hunters were bound, however, to find one conviction. They selected Sarah Daston, a woman of eighty years, who had been called a witch for twenty, and who from her ill-temper and venomous tongue was very unpopular. Her trial, held at Charlestown and attended by a vast throng resulted in her acquittal.

Parris was driven from Salem village by the people and never returned. Noyes, the minister at Salem, regained popular favour only after a full confession of his error from the pulpit and the consecration of the remainder of his life to works of mercy. Judge Samuel Sewall rose in his pew in Old South meeting-house and had read from the desk a declaration expressing his deep repentance that he had been led into such grievous error and asking the congregation to unite with him in praying for his forgiveness. 


\section{\{nn butchingon}

Cotton Mather, however, attempted to vindicate himself. "I know not that ever I have advanced any opinion in the matter of witchcraft but what all the ministers of the Lord that I know of in the world, whether English or Scotch or French or Dutch, are of the same opinion with me," he wrote.

Of course, Massachusetts was not the only colony in which belief in witches existed, either then or for more than a century afterward. ${ }^{4}$ But happily it chanced that it was the only one where the ignorance and credulity of the people were seized upon by bigoted and designing men as a means further to intrench themselves in authority. That seems to have been largely the state of affairs in Massachusetts. But for the sublime egotism of Cotton Mather, ranting, writing, and even believing that the "powers of darkness" were engaged in personal combat with him, it is not probable that there would have been more heard of witchcraft in that colony than any other. "Witchcraft," he had thundered from his pulpit, "is the most nefandous treason against the Majesty on high. ... A witch is not to be endured in heaven or on earth." Replying beforehand to possible 


\section{Dioneer SDothers of America}

sceptics, he said: "God is pleased to suffer devils to do such things in the world as shall stop the mouths of gainsayers, and extort confessions."

His discourse had been printed in 1689 , together with his narrative of recent cases of witchcraft. All the ministers of Charlestown and Boston commended the sermon, as clearly proving that "there is both a God and a devil and witchcraft." Cotton Mather, claiming to have been himself an eye-witness, seemed resolved thereafter to look upon "the denial of devils or witches" as a sort of personal affront, or, as he put it, the evidence "of ignorance, incivility, and dishonest impudence."

The discourse had been reprinted in London and its reception seems to have so turned the man's mind that he could see nothing but witches and their wicked work. With the witch-mad Mather to twist and distort the most innocent and trivial word or action into evidence of diabolical ingenuity and malice, and a dull, stubborn bigot like Stoughton, who owed his place as judge, to Mather, it needed but a vengeful and designing man like Parris to start a reign of terror such as during those awful 
months of 1692 blackened the history of Salem. But it would be as unfair to lay the crime at the door of the people of Massachusetts, or even of Salem, as it would be to hold the Puritan religion accountable for the brilliant inconsistencies of the character of Rev. Cotton Mather.

\section{NOTES TO CHAPTER V}

I Catharine Marbury, a sister of Ann Marbury Hutchinson, married Richard Scott, the first signer of the Providence Compact, and the first Rhode Island Quaker, which faith she espoused. She was whipped in Boston jail by orders of John Endicott, because of her faith and her stubborn refusal to leave the town.

2 Thomas Hutchinson, a descendant of Ann Hutchinson, was the last royal Governor of Massachusetts, having held a number of important offices in the colony. He wrote a history of Massachusetts Bay Colony.

3 This same Mary Dyer was herself to feel the stern hand of churchly authority, when twenty years later she returned to Boston under what she regarded as a divine command to resist the unjust edict against the banishment of the Quakers. When Ann Hutchinson was driven into the woods, Mary Dyer and her husband went also, settling in Rhode Island, where he became Secretary of the colony. In I659, she was in Boston and, together with Marmaduke Stevenson and William Robinson, was banished because they were Quakers. She went home to Rhode Island, but the two men went only to Salem, returning to Boston not long after. They were at once arrested, and she hearing of it felt called upon to join them. All three were sentenced to death and on October 27 were led to the gallows. The two men were hanged while the Rev. John Wilson scoffed at them. They were denied Christian burial and their bodies thrown into a pit. The halter had been placed about the neck of Mary Dyer when her son, who had come in haste from Rhode Island, secured a reprieve from the governor, on condition that he would take her back to Rhode Island. She accompanied her son, but returned the following spring and was hanged June I, I660. 


\section{Dioneer Motbers of Emerica}

4 In 1667, Ralph Hall, and his wife Mary, of Brookhaven, L. I., were tried on a charge of having brought about the death of a man and child by "wicked arts of the Devil." Upon the jury served one Jacob Leisler, a name later to become famous in the annals of New York City. The jury gave a verdict of acquittal for the husband, but made him give bonds for his wife's good conduct. A year later

Governor Nicholls cleared them even of this obligation. 
"Aell the dead might wake to hear
Swelled on the night air, far and clear;

Then smote the Indian tomahawk

On crashing door and shattering lock;

Then rang the rifle-shot, and then

The shrill death-scream of stricken men;

Sank the red axe in woman's brain,

And childhood's cry arose in vain.

Bursting through roof and window came,

Red, fast, and fierce, the kindled flame,

And blended fire and moonlight glared

On still, dead men and scalp knives bared."

Whittier. 



\section{Chapter VI}

\section{Eunice Vâlllíams}

One of the victims of the Sack of Deerfield by the French and Indians in 1704-She with her husband, pastor of the flock, and one hundred and ten other captives were dragged from their homes at midnight in midwinter and started on a march of more than three hundred miles into Canada-Mrs. Williams, Hannah Chapin, Mary Brooks, and several other women perished from the tomahawk or exposure-Rev. John Williams tells the story of their tragic parting-Hannah Chapin's sacrifice-Little Eunice turned Indian.

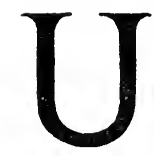

NDER clustering boughs of arbor vitæ, in the old burying-ground in Deerfield, Massachusetts, rest the remains of a woman, the story of whose simple faith, and resignation under terrible suffering, and tragic death reads like that of one of the early Christian martyrs. In fast crumbling letters, chiselled in the weather-stained marble, is the following inscription:

"Here lyeth the body of $\mathrm{M}^{\mathrm{rs}}$. Eunice Williams, the Vertuous \& Desirable Consort of the $\mathrm{Rev}^{\text {nd }}$. Mr. John Williams \& Daughter to $y^{\mathrm{e}} \operatorname{Rev}^{\text {nd }}$. 24 I 


\section{Dioneer Motbers of Emerica}

Mr. Eleazir and Mrs. Esther Mather of Northampton. She was born Aug. 2, 1664, and fell by the rage of the Barbarous Enemy, March I, I703/4. Prov.: 31, 28. Her Children arise up \& Call her Blessed."

By her side sleeps her husband, Rev. John Williams, whose diary of the hardships and sufferings of himself and family, as well as of the little flock to which he ministered when they were carried away from Deerfield, is almost an epic in its simple word painting.

For the story of Eunice Williams and her husband is the story of the "Sack of Deerfield," and typical of the experiences of many border settlements in the French and Indian wars, differing only in the number of captives taken.

A brief summary of the facts pertaining to this act of French and Indian barbarity is necessary to the telling of the bravery and suffering of Mrs. Williams and of the other ill-fated women victims of this savage foray. During the second year of Queen Anne's War, the French Governor of Canada, Marquis de Vaudreuil, sent out a midwinter expedition to destroy this "frontier of the British Government." Deerfield had long 


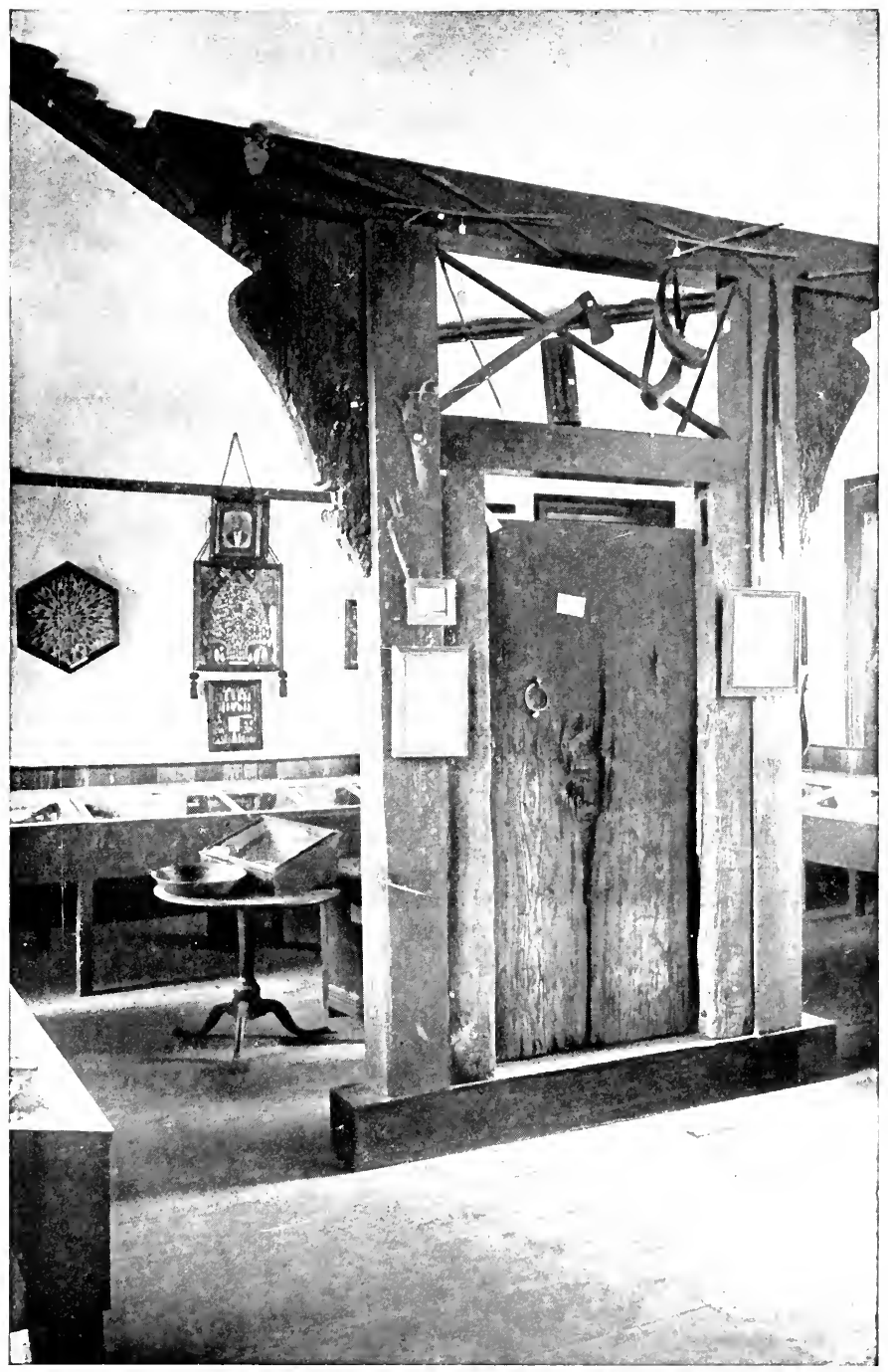

Door of the "Ensign Sheldon House," with its "HatchetHewn Face."

Relic of the sack of Deerfield, February, 1703 t. 



\section{Eunice Wuilliams}

been a storm centre for Indian depredations. During King Philip's War, the settlement had been scattered, but in the spring succeeding the close of that war Quentin Stockwell and five others had ventured the resettlement of the town. In September, of that year, I667, a band of refugee Potumtuck Indians under their own chief came down from Canada. They raided Hatfield without knowing of the little band at Deerfield until the lights from the camp of the Deerfield settlers betrayed their location. Four of the six Deerfield settlers were taken and, with the twenty-four prisoners from Hatfield, started on the long march back to Canada. Of the twenty-eight who started on the weary tramp through the forests, four fell by the way. Three months were consumed in this journey, on which long halts were made at Indian camps, and at the end of the journey the captives were distributed among the French and Indian villages. One of the prisoners, who had served in the war against King Philip, was burned at the stake and a woman captive was forced to fire the pile. One of the Deerfield captives was Benoni Stebbins, who shortly after the party started on their way to Canada made his escape and 


\section{Dioneer SMothers of America}

brought back to the town of Hadley the first news of the destination of the prisoners. A rescue party from Hatfield and the towns below along the Connecticut, soldiers and volunteers, started in pursuit. They were led a bewildering chase up the river, but the Indians had doubled on their tracks, crossing and recrossing the stream repeatedly, so confusing all traces that the pursuing party was forced to return.

"Then followed a knightly quest," writes one historian, "Benjamin Waite and Stephen Jennings, whose entire families were among the captives from Hatfield, armed with papers from the Bay Council authorising their expedition, and with letters from the Bay governor to the French governor and to a great Indian sachem, making overtures for the redemption of the captives. The two men started off on their lonely pilgrimage in the desolate season of December. After extraordinary exertions and grave perils, these adventurous men met with the fullest success. Their families were restored to them and finally, through the help of Frontenac at Quebec, the ransom of the whole party was effected."

Deerfield had, in I704, a population of 268 


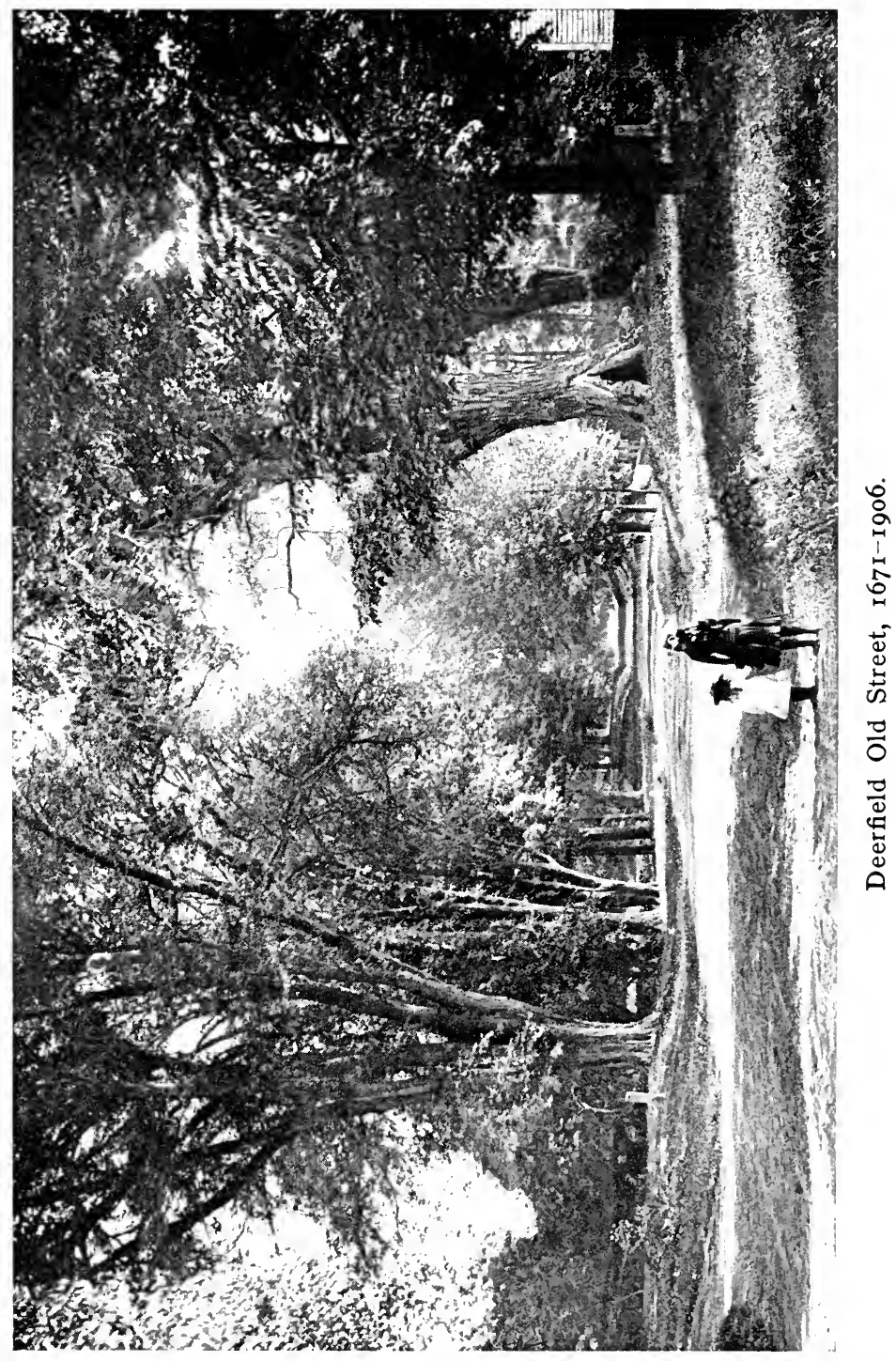





\section{Eunice Vulilliams}

men, women, and children and embraced fortyone houses. Fifteen of the houses were built within the line of the stockade and the others on the north and south of it. The house of the minister, forty-two by twenty feet, with a lean-to and his barn, both of which the town had built for him, stood back on the Common, where now stands the Academy. The house of Ensign Sheldon and Benoni Stebbins stood near and somewhat to the northward. The Sheldon house was the largest in the settlement, and together with the Stebbins house and that of the minister formed a sort of group some twelve or fifteen rods from the houses on the west and south. Sheldon, the historian of Deerfield, a descendant of Ensign Sheldon, writes that on the eve of the sack there were two hundred and ninety-one souls in the little town. Of these, twenty were garrison soldiers; two were visitors from Hatfield, one a friendly Indian, and three negro slaves. The rest were townspeople of all ages, "from Widow Allison of eighty-four to John the youngling of Deacon Trench's flock, of four weeks." In the minister's house were the minister and his wife, seven of their eight living children, with two negro slaves, a man and a 


\section{Dioneer Mothers of Emerica}

woman. In the house of Benoni Stebbins there were three families and a guard. Ensign Sheldon's house sheltered the Ensign and his family and his son who had but a few days before been married to Hannah Chapin of Springfield and brought his bride home with him on horseback, she riding pillion behind him. It was a cold night and the snow lay deep on the ground and was heaped high in drifts against the logs of the stockade.

The attacking party, numbering one hundred and fifty of the Abenaki tribe from Maine and two hundred French soldiers from Montreal, was commanded by Hertal de Rouville, with his brother, Lieutenant de Rouville, as second in command. The French soldiers were supplied with snow-shoes and came down with little difficulty over the crusted snow from the north. They carried with them an extra supply of moccasins and provisions, packed on sleds drawn by dogs. About two hours before break of day, they approached the stockade which, owing to the snow-drifts, was easily surmounted. The sentinel was asleep at his post and only awoke in time to discharge his gun after the French and 


\section{Eunice Vulllliams}

Indians had disposed of themselves about as they wished. Generally the French stayed outside, "standing to their arms and killing all who could make any resistance," as Sheldon writes. The story of the attack on the minister's house is best told by himself:

"They came to my house in the beginning of the onset, and by their violent endeavours to break open doors and windows with axes and hatchets awakened me out of sleep; on which I leaped out of bed and, running toward the door, perceived the enemy making their entrance into the house. I called to awaken two soldiers in the chamber, and, returning toward my bedside for my arms, the enemy immediately broke into the room . . .with painted faces and hideous exclamations. I reached up my hands to the bed-tester for my pistol, uttering a short petition to God for everlasting mercies for me and mine on account of the merits of our glorified Redeemer, expecting a present passage through the valley of the shadow of death. . . . Taking down my pistol, I cocked it and put it to the breast of the first Indian that came up. But my pistol missing fire I was seized by three 


\section{2 Dioneer Mothers of Âmerica}

Indians who disarmed me, and bound me naked, as I was in my shirt, and so I stood for near the space of an hour. Binding me, they told me they would carry me to Quebec. My pistol missing fire was the occasion of my life's being preserved; since which I have also found it profitable to be crossed in my own will. . . I cannot relate the distressing care I had for my own dear wife, who had lain-in but a few weeks before; and for my poor children and Christian neighbours. . . .

"The enemy fell to rifling the house, and entered in great numbers into every room. I begged of God to remember mercy in the midst of judgment; that he would so far restrain their wrath as to prevent their murdering of us; that we might have grace to glorify his name whether in life or death; and, as I was able, committed our state to God. The enemies who entered our house insulted over me awhile, holding up hatchets over my head, threatening to burn all I had; but yet God, beyond expectation, made us in a great measure to be pitied. For though some were so cruel and barbarous as to take and carry to the door two of my children and murder them, as also a negro woman, 


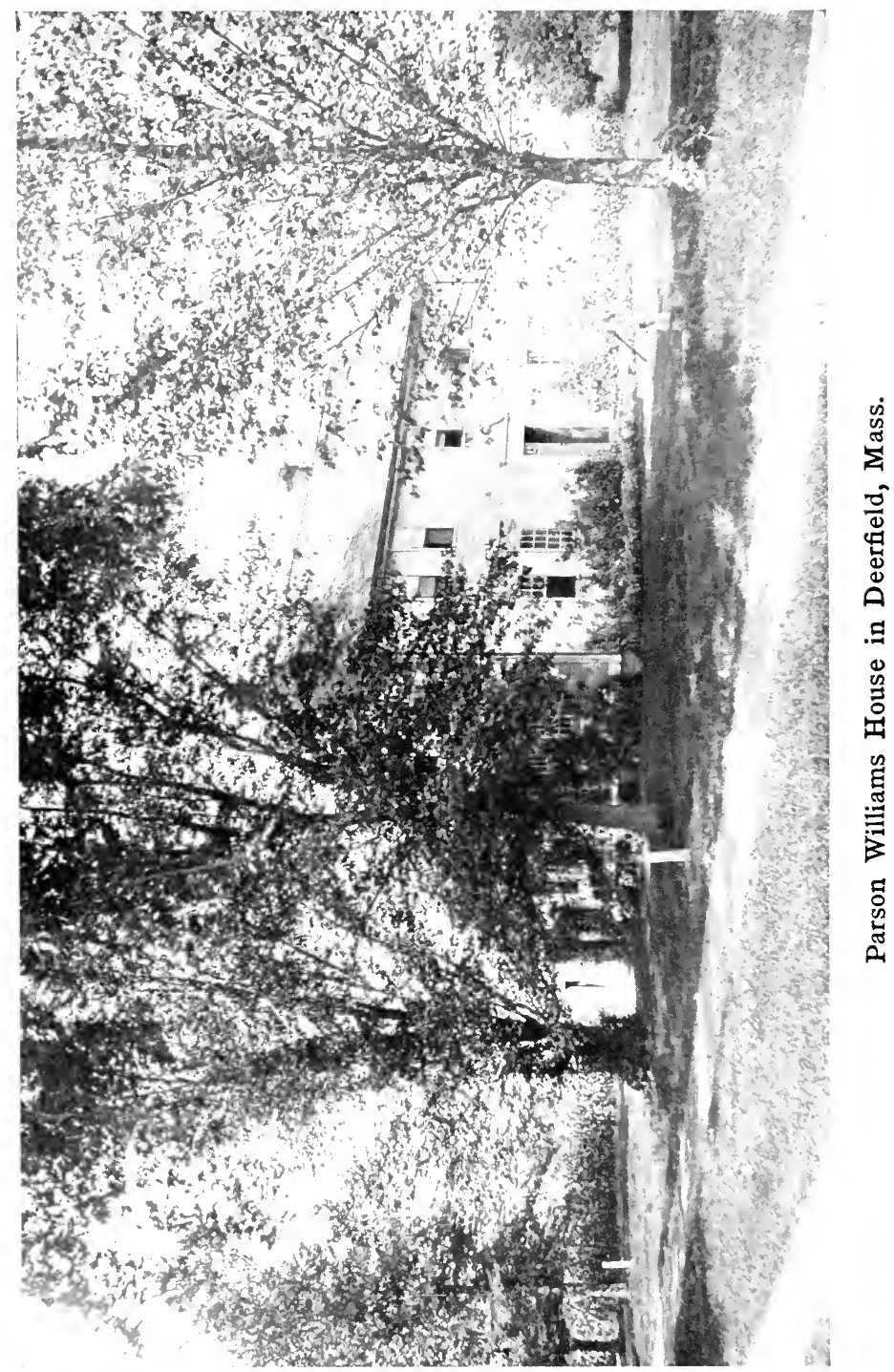





\section{Eunice rullliams}

yet they gave me liberty to put on my clothes, keeping me bound with a cord on one arm till I put on my clothes to the other; and then changing my cord they let me dress myself and then pinioned me again. Gave liberty to my dear wife to dress herself and our remaining children. About sun an hour high we were all carried out of the house for a march, and saw many of the houses of our neighbours in flames, perceiving the whole fort, one house excepted, to be taken. . . Upon my parting from the town they fired my house and barn."

There was but one house that escaped, in the group in the upper part of the stockade. That was the Ensign Sheldon house, the largest and best built in the community. Its heavy oaken front door was chopped and slashed with axes and hatchets, but while the door was cut through it could not be broken down. The Indians shot at random through the opening the hatchets had made, and the Ensign's wife, who was sitting in her bed, was shot and killed. Young John Sheldon and his bride were sleeping in a room in the second story. They ran down into Mrs. Sheldon's room when she was killed 


\section{Dioneer Mothers of America}

and, finding her beyond the need of earthly helping, sprang out of the window. Hannah the bride sprained her ankle in the fall and was unable to walk. Bravely she urged her young husband to leave her and fly to Hatfield for aid. He protested, but she insisted and, "binding strips of a woollen blanket about his naked feet, he ran. The young wife was almost immediately taken prisoner. The Indians forced an entrance into the house through a back door and captured the remaining inmates. The Ensign's little two-year-old daughter was taken to the door and her brains dashed out on the door-stone. The house was set on fire, but the blaze was extinguished and the building stood for a century and a half, a landmark of the "Old Fort," and the "Sack of Deerfield." The battered front door, still attached to the original door-posts, is one of the most interesting relics yet preserved by the Memorial Association, a short distance from its original site.

The inmates of the Benoni Stebbins house made a stubborn resistance, which was to have been expected of the old Indian fighter-the same Benoni Stebbins who had escaped from the marauding band that attacked the little settle- 


\section{Eunice ralliams}

ment in I667. They were attacked a few minutes later than the other houses in that part of the stockade and so had more time to put themselves in a state of defence. There were three families in the house, besides two soldiers-seven men and three women. The women, as well as the men, stood with guns behind windows and at loopholes. The first rush of the Indians was met by such a well-directed fire that they fell back in great disorder. A second assault was met in the same manner and with the same result. Then came a breathing spell for the beleaguered household while the Indians joined in the pillage of some of the other houses. Again they rallied, the French soldiers taking part in the assault. Several more of the enemy fell including the young French Lieutenant de Rouville and the Macqua chief who had led the attack upon the house of Parson Williams. Again the attacking party was forced to fall back, by the well directed and steady rifle-fire of the besieged, and took refuge in the Sheldon house, which was now in the hands of the enemy, and in the meeting-house. From these shelters the attack was carried on. But always the besiegers were held in check by the deadly fire 


\section{Dioneer SMothers of Emerica}

from the rifles of the little band of settlers. Then came relief. A party of thirty men on horseback, gathered by the despairing call of young Sheldon and the smoke of the burning buildings, dashed into town, and the enemy, hastily massing their captives and carrying their plunder, hurried away. In an unfortified house, seven men and three women had held in check "so great a number of French and Indians as three hundred," as Parson Williams puts it. The historian Sheldon makes this comment: "In all the wars of New England there is no more gallant act recorded than this defence.'

Of the defenders, only one was killed, doughty Sergeant Stebbins. Mrs. Hoyt was wounded, and we know but little more of her than this brief record of her bravery. The members of the little garrison joined in the chase after the retreating French and Indians. There were fifteen Deerfield men joined with the rescuing party, and led by Captain Wells they pursued the enemy until they ran into the "inevitable ambush," in which nine men were killed and the others chased back. "Of the town's two hundred and sixty-eight inhabitants, all but one 


\section{Eunice Tolilliams}

hundred and twenty-six were either killed or were in the hand of the enemy on the march to Canada, more than three hundred miles through the wilderness.

To the Rev. John Williams, the Deerfield minister, and the faithful and graphic account of the hardships and sufferings of the journey as told in his Redeemed Captive Returning to Zion, we are indebted for what we know of this march. Sheldon, the historian of Deerfield, drew largely from this source and supplemented it with the journal of Stephen Williams, son of the minister, himself a boy of about twelve years. More than half the one hundred and twelve prisoners, Sheldon says, were under eighteen years of age, forty of them not over twelve, and twelve under five. One of the latter, a "suckling child," was killed before the march began. All were provided with moccasins in place of their shoes. Twentytwo of them were to fall under the cruel tomahawk, or to perish on the march from exposure or hunger. Two were to have the good fortune of escaping. Only sixty were to return to their friends. The rest were to adopt Indian or French habits; some to intermarry 


\section{Dioneer SDothers of America}

with their captors; some to enter the Catholic religious orders in Canada.

"We travelled not far the first day," writes the minister. "When we came to our lodging place for the first night (in a swamp in Greenfield meadows), they dug away the snow and made some wigwams, cut down some small branches of the spruce tree to lie down on, and gave the prisoners something to eat; but we had little appetite. I was pinioned and bound down that night; and so I was every night whilst I was with the army. Some of the enemy who brought drink with them from the town fell to drinking, and in their drunken fit they killed my negro man. In the night an Englishman made his escape; in the morning I was called for, and ordered by the General (Rouville) to tell the English that if any more made their escape they would burn the rest of the prisoners."

On the morning of the second day, the good pastor was pleased by the leniency of his "master," who gave him the privilege of walking for awhile with his wife when they overtook the poor woman, dragging her weak limbs through the trackless snow.

"On the way, we discoursed of the happiness 


\section{Eunice rollliams}

of those who had a right to a house not made with hands, eternal in the heavens; and God for a father and friend; as also, that it was our reasonable duty quietly to submit to the will of God, and to say, 'The will of the Lord be done.' My wife told me her strength of body began to fail, and that I must expect to part with her; saying she hoped God would preserve my life and the life of some if not all our children with us; and commended to me, under God, the care of them. She never spake any discontented word as to what had befallen us, but with suitable expressions justified God in what had happened. We soon made a halt, in which time my chief surviving master came up, upon which I was put upon marching with the foremost; and so made my last farewell of my dear wife, the desire of my eyes, and companion in many mercies and afflictions. Upon our separation from each other we asked for each other grace sufficient for what God should call us to do. After our being parted from one another she spent the few remaining minutes of her stay in reading the Holy Scriptures."

It was not long that the good woman had to 


\section{Dionecr Motbers of Elmerica}

wait. In crossing Green River, through which all were compelled to wade, "the water being above knee deep, the stream very swift," she fell prostrate in the chilling current. Weakened pitifully by her fall, she staggered but little beyond when "the cruel and bloodthirsty savage who took her slew her with his hatchet at one stroke."

Word of her fate reached the minister while he was resting at the top of the hill: "No sooner had I overcome the difficulty of that ascent but I was permitted to sit down and be unburdened of my pack. I sat pitying those who were behind, and entreating my master to let me go down and help my wife; but he refused and would not let me stir from him. I asked each of the prisoners, as they passed me, after her (and so got the awful tidings of her taking off). And yet such was the hard-heartedness of the adversary that my tears were reckoned to me as a reproach. My loss and the loss of my children was great; our hearts were so filled with sorrow that nothing but the comfortable hopes of her being taken away in mercy to herself from the evils we were to see, feel, and suffer under . . . could have kept us from sinking under at that 


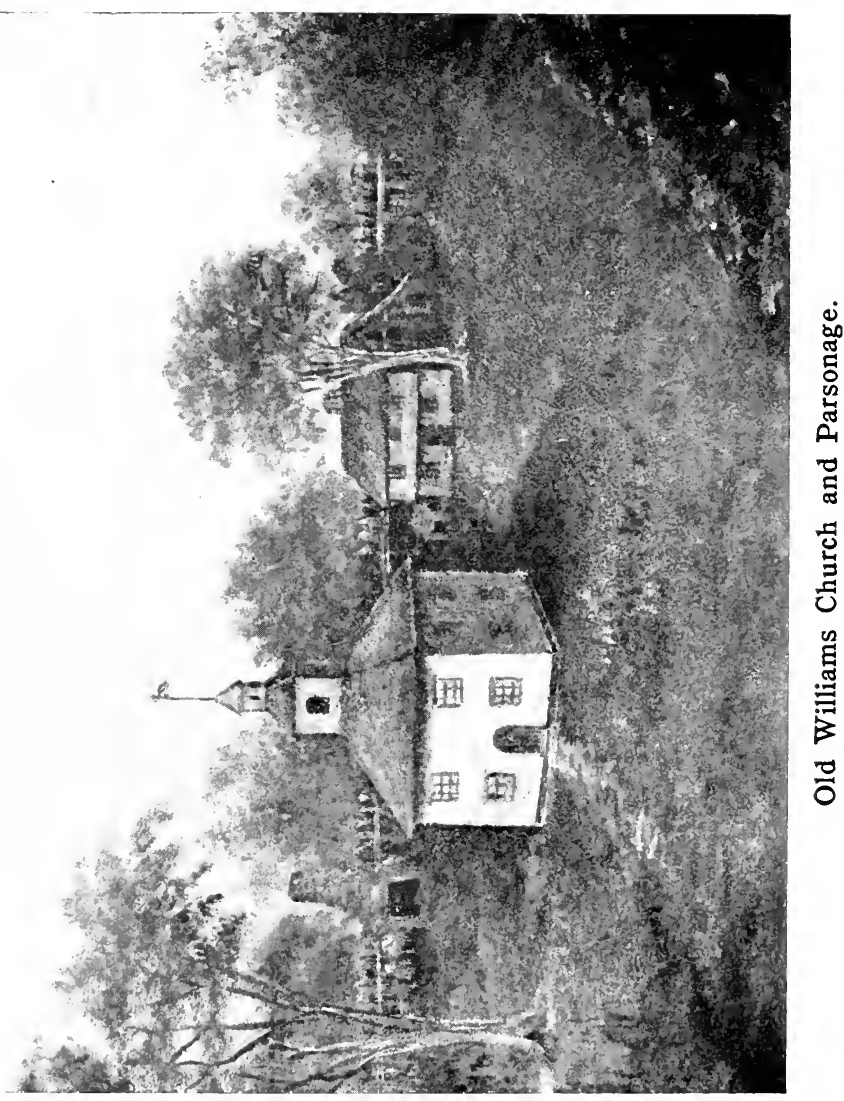





\section{Eunice Vulllliams}

time. . . We were again called upon to march, with a far heavier burden on my spirits than on my back."

Mrs. Williams was under forty years of age when she met her untimely death, and had been the mother of eleven children, six of whom survived her. A monument erected by the Pocumtuck Memorial Association of Deerfield marks the spot where she fell and where her body was found, by a party of Deerfield men several days after the captives had passed, and borne sorrowfully back to her old home for burial.

The trail over which the French and Indians led their captives led past where the towns of Leyden, Bernardstown, and Vernon now stand, over the Vermont line to Brattleboro and the mouth of West River. On the second day, an infant in arms was killed, and a little girl four years old, and later another unhappy woman, who "being near the time of her travail was wearied with her journey," was ruthlessly dispatched. Evidently their journey must have reeked with horrors, as both Parson Williams and Historian Sheldon tell of these brutalities with a paucity of details that have left the vic- 


\section{Dioneer MDother of Elmerica}

tims nameless. On their way to the attack, de Rouville's party had left the dog teams and sleds at the mouth of West River. On their way back to Canada, with their captives, these were taken up and the march up the frozen river was continued with greater haste because a thaw was feared with a general breaking up of the ice. Sometimes, some of the children were drawn on the sleds by the Indians, along with their own sick and wounded and their packs. On the third day, the speed was so great that four women became tired out and "were forthwith slain." Young Stephen Williams's diary of this time records that "they killed near a dozen of women and children, for their manner was if any loitered to kill them."

The whole company was allowed to rest for the day on their first Sunday, at the mouth of Williams River, and the minister was allowed to hold services for the remnants of his sorrowing flock. It is recorded that "he prayed with his stricken people and preached them a sermon, taking for his text, Lam. i., I8: The Lord is righteous; for I have rebelled against his commandments: hear, I pray you, all people, and behold my sorrow: my virgins and my young 


\section{Eunice Trailliams}

men have gone into captivity.' Then at the call of the Indians to 'sing us one of Zion's songs,' he and the congregation lifted up their sad voices in a familiar hymn." Mr. Williams takes occasion, in this connection, to comment upon the difference between the treatment of the Indians and the "papists," in the matter of this freedom of worship. "When the Macquas and Indians were chief in power we held this revival in our bondage, to join together in the worship of God, and encourage one another to a patient bearing the indignation of the Lord till he should plead our cause. When we arrived at New France, we were forbidden praying one with another, or joining together in the service of God."

On the next day's march, however, two more women who had become too faint to travel were put to death, and the next day, according to the journal of the minister, there occurred another pathetic parting, with an exhibition of the wonderful fortitude as well as faith of the women of this captive band:

"In the morning before we travelled one Mary Brooks, a pious young woman, came to the wig- 


\section{Pioneer Mothers of America}

wam where I was and told me she desired tc bless God who had inclined the heart of her master to let her come and take leave of me. Said she: 'By my falls on the ice yesterday I injured myself, causing a miscarriage this night, so that I am not able to travel far; I know they will kill me to-day; but,' says she, 'God has (praise be his name!) by his spirit, with his word, strengthened me to my last encounter with death,' and so mentioned to me some places of Scripture seasonably sent in for her support. 'And,' says she, ' I am not afraid of death; I can, through the grace of God, cheerfully submit to his will. Pray for me,' said she, at parting, 'that God would take me to himself.' Accordingly she was killed that day."

At the mouth of White River, the French and Indians were divided into small parties by de Rouville and each with its portion of the captives scattered in various directions. Mr. Williams with his children, excepting Stephen, was taken up the valleys of the White and Winooski rivers, Lake Champlain, the St. Lawrence and Sorel rivers to the French village of Chambly, about fifteen miles below Montreal. The hard- 


\section{Eunice ronilliams}

ships of the captives in the party to which $\mathrm{Mr}$. Williams was attached were but little relaxed after this subdivision. On their first day out a Macqua Indian, finding the snow too deep to comfortably carry his pack and a little fouryear-old girl whom he had taken, killed the child. Still there were some redeeming features, the minister found. His own children seemed to fare exceptionally well. His little daughter Eunice, seven years old, was "carried all the journey, and looked after with a great deal of tenderness." The little boy, Warham, aged four, was "wonderfully preserved from death; for though they that carried him or drew him on sleighs were tired with their journeys, yet their savage, cruel tempers were so overruled by God that they did not kill him, but in their pity he was spared, and others would take care of him; so that four times on the journey he was thus preserved till at last he arrived in Montreal." So also the elder son Samuel, and the eldest daughter Esther, "were pitied so as to be drawn on sleighs when unable to travel." Mr. Williams himself was helped by his Macqua master, who made him a pair of snow-shoes upon which he walked twenty-five miles the first day he wore 


\section{Pioneer SDothers of Emerica}

them. At another time when he was footsore, the Macqua relieved him of his pack, drawing it on the ice with his own.

At Chambly, the minister was received in the house of a French gentleman and treated with hospitality, enjoying once more the luxury of "a good feather bed" and civilised cooking. His four children, who had been separated from him near the end of the journey, were all, with the exception of little Warham, in or near Montreal, in the Indians' hands. Warham had been bought by a French gentlewoman, from the Indians. The other captives were held by the Macquas. Mr. Williams after a few days was taken to Montreal and placed in charge of the Governor, by whom he was held, to exchange for Captain Baptiste, a French prisoner held in Boston. Mr. Williams testifies that the governor's treatment of him was "courteous and charitable to admiration." The Governor also exerted himself to get the other captives out of the hands of the savages, and especially to redeem the other Williams children. To this quest, also the Governor's wife lent kindly aid. All the children were ultimately redeemed except the little girl Eunice. The Macquas would 


\section{Éunice rallliams}

not give her up at any price. She remained with the Indians permanently, learning their language and customs as she lost her own. She became a Catholic under the teaching of the nuns and, when she had come to womanhood, was married to a Caughnawaga chief who took her name of Williams. It was something over a year before the father again saw his son Stephen. The boy had passed through hardships and adventures and become skilled in the woodcraft of the Indians. $\mathrm{He}$ was finally ransomed and rejoined his father near Montreal.

But while the good minister's creature comforts were seemingly well considered, his peace of mind was gravely disturbed by the efforts of the Jesuit missionaries to force "Popery" upon his captive flock. Every effort and artifice was used by these ever-zealous priests to bring him into the fold of the Roman Catholic Church, and he was "cajoled, flattered, threatened, reasoned with, and badgered incessantly." At Quebec, the Intendant offered to turn over to him all the captives of his flock and his children and secure him "a great and honourable pension from the King every year," if he would become a Catholic. "Sir, if I thought your 


\section{Dioncer Mothers of America}

religion to be true I would embrace it freely; . . . but so long as I believe it to be what I do, the offer of the whole world is of no more value to me than a blackberry." As the negotiations for the exchange of prisoners were completed, efforts of the French priests became more urgent. "I cannot tell you," writes Mr. Williams, "how the clergy and others laboured to stop many of the prisoners. To some, liberty; to some, money and yearly pensions, were offered if they would stay. . . ." Some of the younger ones were told, to frighten them, that if they went home they would be damned and burnt in hell forever. Day and night, they were urged to stay. At Miontreal, especially, all crafty endeavours were used to detain them.

However, the minister succeeded in gathering together most of the flock, and fifty-seven took passage on a vessel which sailed from Quebec in October, I706, and reached Boston a month later. In the party, came but two of the Williams children, Samuel and little Warham. Stephen had returned the year before with Col. William Dudley, son of Governor Dudley, who had gone to the French province with proposals for an exchange of prisoners. Esther, 


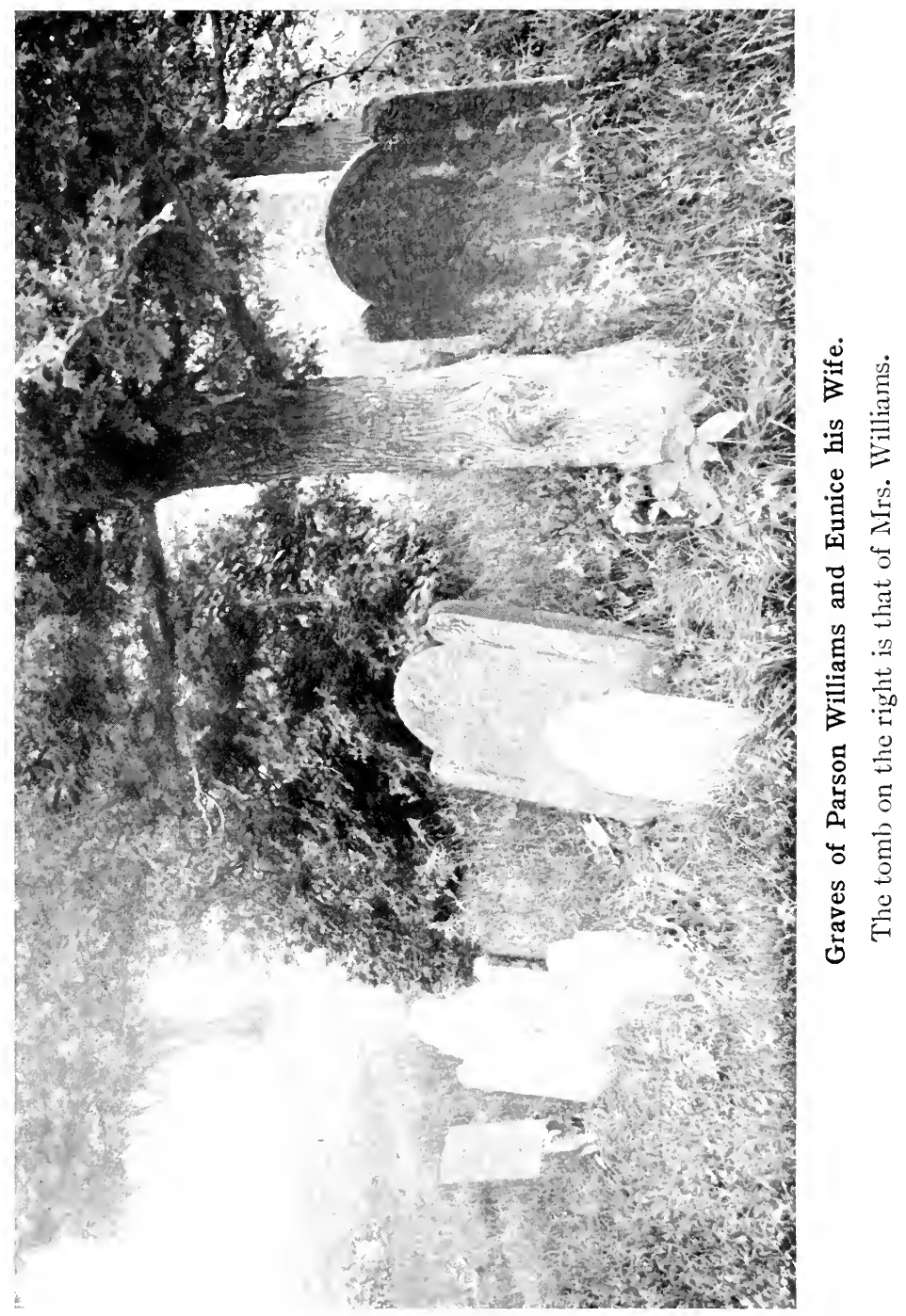





\section{Eunice Trallliams}

the eldest daughter, had been brought home some months before by Ensign John Sheldon, together with two of his own children and his daughter-in-law Hannah (Chapin) Sheldon. This was the first expedition from Deerfield in quest of the captives. Sheldon made the trip in the winter season on snow-shoes, and accompanied by Captain John Livingston of Albany as pilot and young John Wells of Deerfield, whose mother was among the captives and who had lost a sister in the sack of the town. Ensign Sheldon had four children among the captives, together with his dead wife's brother with a large family. He carried proposals from Governor Dudley to the Marquis de Vaudreuil, Governor of Canada, but his mission seems to have been but partially successful as he brought back only two members of his own family and Esther Williams. With him, however, came a commissioner from the French Governor to open negotiations for the exchange of prisoners. A second expedition he made late in the winter of $1705^{-6}$, which secured the release of fortythree captives, most of whom were Deerfield folk. The return of Parson Williams to Deerfield in 1706 seemed to put new life and heart 


\section{Pioneer Mothers of America}

into the town. The authorities at once voted to build a new house for the minister, as "big as Ensign Sheldon's," and before the close of his first year back home he was comfortably settled in the new parsonage, with all his children except Eunice around him, and with another wife. This second helpmeet was Abigail Bissel, widow of Benjamin Bissel of Hartford and a cousin of the martyred Eunice.

Eunice Williams left four sons, three of whom were in captivity with their father, and Eleazar, who was away at school and thus escaped capture. He became a minister, as did also Stephen and Warham, all of whom graduated from Harvard and served long lives in the ministry. Samuel, another son of Eunice, returned from captivity speaking the French language fluently; but his health was broken and he never fully recovered. He served as town clerk of Deerfield and died in I7I3. Esther, the eldest daughter, married a minister of Coventry, Connecticut. Eunice, the daughter who had been left with the Indians, never returned to civilised life. Her father accompanied an expedition into Canada in I709, and again in I $7 \mathbf{I}$, in the hope of rescuing her, and again when, in 


\section{Eunice rullliams}

I7 I4, he and Captain Stoddard were commissioners to negotiate an exchange of prisoners, they made every effort to secure her return, but the father never reached her. Years afterward, Stephen Williams found her and induced her to visit him at his home in Longmeadow. "She came," writes Bacon in his The Connecticut River, " in her Indian garb, bringing her husband and train of grave-visaged Indians. She greeted her brother with affection; but she was firmly attached to the life of the forest, and civilisation had no attractions for her. Her party would not lodge in her brother's house, but occupied a wigwam which they set up in the orchard behind the parsonage. This incident of her visit has been related by a granddaughter of Stephen Williams: 'One day my grandmother and her sisters got their Aunt Eunice into the house and dressed her up in our fashion. Meanwhile the Indians outside were very uneasy; and when Eunice went out in her new dress they were much displeased, and she soon returned to the house begging to have her blankets again.' She lived to a great age, dying in her forest home after the close of the Revolution. Two of her great-grandsons, John andEleazar Williams, spent 


\section{Dioneer SMothers of Almerica}

some years of their boybood in Longmeadow, receiving their education under Nathaniel Ely, who had married a granddaughter of Stephen Williams. One of these, Eleazar, ${ }^{2}$ became a minister among the western Indians. He attained greater notoriety in his later life through his acceptance of the claim that he was not of Indian blood, but of royal French ancestry,- the real "lost dauphin' of Louis XVI and Marie Antoinette," a romance of history long since closed.

Rev. John Williams died in I729, in his sixtyfifth year, and was buried in the old graveyard by the side of the martyred Eunice. Abigail, the second wife, survived him a quarter of a century and, dying at the age of eighty-one, was buried by the side of the minister. Nearby sleep the remains of Ensign and Hannah Sheldon, and in a corner of the yard is a mound which marks the last resting-place of the victims of the Sack- "The dead of I 704."

\section{NOTES TO CHAPTER VI}

'John Sheldon's house was so thoroughly typical of the better class of pioneer New England homes that a description may not be out of place. Its frame was largely of oak. It was 2 I by 42 feet; two stories with a steep pitch roof. In front the second story projected about two feet, the end of the cross-beams being supported by ornamental brackets (two of which are preserved). A lean-to, 


\section{Eunice Tchilliams}

13 $1 / 2$ feet wide, ran the whole length of the north side, its roof being a continuation of that on the main building. The ground floor was thus $34 \frac{1}{2}$ by 42 feet. Near the centre was the chimney, about ro feet square at the base, with fireplaces on the side and rear. South of it was the front entry which, including the stairways, was 8 by I2 feet. The lower floor was laid under the sill which, projecting beyond the wall, formed a ledge around the bottom of the rooms, a tempting seat for the children. Stepping over the sill into the front entry, doors on either hand opened into the front rooms. Stairs on the right led by two square landings and two turns to a passage over the entry, from which at the right and left doors led to the chambers. In the rear of the chimney was a small dark room, with stairs to the garret. Including the garret there were five rooms in the main structure, each of them lighted by two windows with diamondshaped panes set in lead. The kitchen was in the centre of the lean-to, with windows in the rear. East of this was a bedroom, and west a buttery and back entrance. The fireplace was a deep cavern, the jambs and back at right angles to themselves and the floor. Here, hanging on nails driven into a piece of wood built into the structure, for the purpose, hung the branding iron, the burning iron, the pothook, the long-handled frying-pan, the iron peel or oven slice, the scooped fire shovel with stout tongs standing by. In one end was the oven, its mouth flush with the back of the fireplace. The mantel-tree was a huge beam of oak protected from the blaze only by the cold air constantly ascending. The fireplaces in the front rooms were of the same pattern, only smaller. The partition and wall were of panel work with mouldings about the doors and windows.

2 Eleazar Williams was the claimant over whom controversy waged warm fifty years ago. "Older readers," writes Bacon in his book The Connecticut River, "will remember the circumstantial story of the Rev. John H. Hanson in his papers, 'Have we a Bourbon among us?' and 'The Bourbon Question,' published in Putnam's Monthly of $\mathrm{I} 853$, which opened the dispute, and his subsequent book, The Lost Prince, restating the story, and with not a little skill dealing with the critics and ridiculers of the claim. They will recall also the battle of the pamphleteers, for and against the claim, which continued after the death of the claimant in 1858 , and lately the story has been revived for modern readers in an English publication, based almost entirely upon Dr. Hanson's book, with but slight if any consideration of the strong evidence adduced by his contemporaries 


\section{Dioneer Mothers of America}

against his theory. The basis upon which the Williams claim was made principally to rest was in three propositions: the alleged declaration of his identity as the dauphin made to him by the Prince de Joinville at Green Bay, Wisconsin, in October, I 841 , upon the occasion of de Joinville's second visit to America; de Joinville requested Williams to sign an abdication of the throne which he declined to do: Williams's remarkable likeness in feature and figure to the Bourbons, and particularly to Louis XVI: the appearance on his person of a scar at the exact point indicated where it should be; this showed the mark of a crescent-shaped lancet which the Duchesse d'Angoulême had said, when she rejected the claim of Naundorf, would be found on her brother, made by the surgeon at the time of his inoculation for the purpose of identification. Against these assumptions or declarations, counter evidence was brought (with the documents assuming to attest the death of the real dauphin in the Temple) to show that the fabric had been principally erected on Williams's 'say so'; that there was nothing substantial in support of the tale of the secret bringing of the dauphin to America and his sequestration with the Iroquois chief, the reputed father of Eleazar; that the likeness of Eleazar to the Bourbons, if not largely imaginary, had no significance; that he had the pronounced marks of the half-breed; and that his head had been turned by stories of his 'royal origin' told him by some French officers. The last words in the controversy were said in Putnam's Magazine in 1868, against the claim, by the Rev. C. F. Robertson, afterwards Bishop of Missouri, who was the literary executor of Eleazar, and for the claim, by the Rev. Francis Vinton of Brooklyn, afterwards of Trinity Church, New York. In Dr. Vinton's statement were related incidents which he had not been allowed to publish during the lives of the persons concerned, the principal one being an astonishing recognition of Williams as a Bourbon by Prince Paul William, Duke of Würtemberg, in Mr. Vinton's Brooklyn church on a certain Sunday in 1853 when Williams was assisting in the service; while Dr. Vinton clinched the whole matter, at least to his own satisfaction, with the declaration that he himself had seen the identifying mark of the crescent on the back of Williams's shoulder. Certain soldiers, General Cass and General A. E. Ellis among them, who knew Williams ridiculed his 'claim,' and declared him to be a vain deceiver and dissembler. The Episcopal ministers defending his cause pictured him as simple minded, devoted to his missionary work, a loyal Indian leader in the war of 1812 , abashed rather than elated by the notoriety that had come to him." 
$B^{R A V E}$ foremothers of Freedom's birth,

Smile through space on your splendid daughters;

At one with Liberty lighting the earth,

Their torches flame o'er the darkest waters.

They lend a lustre to sea and land;

They sweeten the world with their wholesome graces, As out in the Harbour of Life they stand,

To cheer and welcome the coming races.

Ella Wheeler Wilcox. 



\section{Chapter VII}

\section{Some Motewortby Taomen of Colonial Times}

Margaret Winthrop, a Puritan mother of the Old Bay ColonyMargaret Brent, a Maryland Portia, the first woman in America to demand the right to vote-Lady Mary LaTour, a Huguenot heroine of Acadia, whose defence of Fort LaTour is still the theme of song and story-Martha Pitkin, an English maid who became the mother of a long line of noted Colonial descendants-Ruth Wyllys, the patriotic young matron who helped save Connecticut's charter by hiding it in the oak-Letitia Penn, a Quaker maid, whose father founded a great cityHannah Dustin, a prisoner of the sack of Haverhill and her awful revenge-Betty Martin, a Colonial belle from the shores of Chesapeake who lived a century.

\section{A ARgaret Winthrop, wife of John Winthrop, first Governor of Massachusetts Bay Colony, was} eminently typical of the best Puritan womanhood and Puritan motherhood. Of that we are assured by the records of her life, scanty though these be, as well as the written testimony of her husband and neighbours. By no people was ever womanhood held in higher regard 


\section{Dioneer SMothers of America}

than by the Puritan fathers, but always it was womanhood in the seclusion of the home as wife, mother, and helpmeet. Hence it is that the story of Margaret Winthrop is largely the story of John Winthrop, with brief glimpses incidentally of the life of the devoted, affectionate, virtuous, and pious woman who thought as he did, believed as he did, and was entirely satisfied to work for him, care for him, and, so far as lay in her power, to shelter him from the cares and anxieties that came with his responsibilities. But as to her personal opinions and peculiarities, her likes and dislikes, her daily walk and conversation, we know practically nothing. "Until Ann Hutchinson came to Boston, the women of that town had not had an opinion of their own," writes a witty woman of the later days, and the records would seem to verify the facetious statement, did we not know that by the customs and conventionalities of all the New England colonies, whatever opinions the Puritan mother may have entertained or whatever influence she may have exerted were only recorded where necessary to set down the deeds, actions, or sayings of the particular Puritan father to whom she was attached as mother, wife, or daughter. 


\section{Tulomen of Colonial Times}

Consequently, while John Winthrop undoubtedly loved his wife devotedly, and held in vast admiration her many sterling qualities, and notwithstanding the fact that he wrote volumes about the life and time of the young colony and his own reflections upon almost every subject, we do not know whether his wife was dark or fair, short or tall, stout or slight, nor the colour of her eyes and hair, and almost as little of her mental attributes.

Margaret Winthrop was the third wife of the sober young Puritan lawyer who was chosen as first Governor of the Massachusetts Bay Colony. She was daughter of Sir John Tyndal of Essex County, England, a Master in Chancery, who had been killed not long before, by a half demented litigant, named Bertram, who held Tyndal responsible for an adverse decision rendered in the Court of Chancery. The Tyndals and Sir John Deane, Mrs. Tyndal's son by a former marriage, were folk of much dignity and prominence in Essex County and related to a number of other families of prominence. Margaret Tyndal was twenty-seven years old, and her widowed suitor twenty-nine, when he came to wed her. Lady Tyndal greatly favoured 


\section{Pioneer SMothers of Elmerica}

the suit, though there was some opposition by other of her relatives; but this did not seem to influence the young woman and they were married in April, I6I8, and went to live at Groton Manor, the family home of the Winthrops.

For the next eleven years, the life of Margaret Winthrop was the life of the quiet woman of rank among the English rural gentry. She was never of the gay or fashionable set and beyond the occasional formal visits to the various relatives of the two families, most of her time was given up to regulating the affairs of her household and caring for her family, which included the four children of Mr. Winthrop by his first wife, and her own fast growing little brood. Stephen, her first-born, came in April, I6I9; Adam, the second of her sons, was born two years later, and later came Deane and Samuel. There was a considerable family at Groton Manor as John Winthrop's father, Adam Winthrop, and his wife Anne, a woman of education and character, lived there, as well as his sister Lucy, a young lady of eighteen. John Winthrop was absent from home much of the time, either in Chambers in London or on circuit, and their 


\section{tramen of Colonial Times}

letters, some of which have been preserved, show a great depth of affection as well as piety. When he had finally decided to go to Massachusetts, he wrote to his wife from London to break the news, for there were circumstances which rendered it impossible for him to take her with him:

"I sende thee herewith some papers concerning N. E.; when thou lookst upon them, thou wilt bear with the brevitye of my letters; I would have Fourth [his son] read the book to thee; for the loose papers let him write them out better and then read them ... especially that gratious letter in the end, which I wishe thee and the rest to reade seriously over. . . . I shall be as lothe to leave my kinde wife behinde me as she will be to stay but we must leave all in God's Providence.

"I am verye sorry that I am forced to feed thee with letters when my presence is thy due and so much desired, but my trust is, that he who hath disposed of it, will supply thee with patience and better comforts in the wants of him thou so much desirest; The Lord is able to doe this and thou mayst expect it, for he hath promised it. Seeing he hath called me into 


\section{Dioneer Mothers of America}

his worke, he will have care of thee and all our affairs in my absence; therefore I must send thee to him for all thou lackest; goe boldly (sweet wife) to the throne of Grace; if anything trouble thee, acquainte the Lord with it; tell him he hath taken thy husband from thee, pray him to be a husband to thee, a father to thy children, a master to thy household, thou shalt always finde him faithfull; thou art not guilty of my departure, thou hast not driven me away by any unkindness, or want of dutye, therefore thou mayst challenge protection and blessings from him."

Mrs. Winthrop replied to this letter in the same spirit, as follows:

"I know not how to expresse my love to thee or my desires of thy wished welfare, but my hart is well knowne to thee, which will make relation of my affections though they may be small in appearance; my thought are more on our great change and alteration of our course heare, which I beseech the Lord to bless us in \& my goode Husband cheere up thy hart in the expectation of God's goodness to us, and let nothing dismay and discourage thee; If the lord be with us who can be against us; my grefe 


\section{Tulomen of Colonial Times}

is the feare of staying behinde thee but I must leave all to the good Providence of God."

Writing on board the Arabella, which is to bear him to New England, off Cowes, March 28, 1630, the Governor sends his final good-bye and plans that spiritual meeting twice a week that has been likened to Shakespeare's Posthumus and Imogen: "Mondays and Fridays at five of the clock at night, we shall meet in spirit till we meet in person. Yet, if these hopes should fail, blessed be our God that we are assured we shall meet one day, if not as husband and wife, yet in a better condition."

To add to the poignancy of the mother's grief at the separation, the Governor took with him two of her boys, Stephen and Adam. John Winthrop, Jr., the eldest son by the Governor's first wife, was left behind to close up his father's business. He had just returned from extended journeying in foreign countries and must at this time have been a tower of strength to both father and stepmother. Old and thoughtful beyond his years, open-hearted and kindly, he had from early youth given brilliant promise for that rare fulfilment that came with his more mature manhood. 


\section{Dioneer SDotbers of Emerica}

Of the sad condition in which Governor Winthrop and his compeers found the little colony, through sickness and privations, of the death by drowning of Henry Winthrop, one of the sons of the first wife, and of the multitudinous duties and responsibilities that crowded upon the Governor almost from his landing, we will not at this point speak, though they came to be of almost as vital importance to Margaret Winthrop as to her husband. Finally the long separation was over. In November, I63I, Governor Winthrop wrote in his voluminous journal:

"Nov. 2. The ship Lyon, William Pierce master, arrived at Natascot. There came in her the governor's wife, his eldest son and his wife and others of his children, and Mr. Eliot a minister, and other families, being in all about sixty persons, who all arrived in good health, having been ten weeks at sea, and lost none of their company but two children, whereof one was the governor's daughter Ann, about one year and a half old, who died about a week after they came to sea.

"4. The governor, his wife and children, went on shore with Mr. Pierce in his ships boat. 


\section{raomen of Colonial Times}

- . At their landing the captains, with their companions in arms, entertained them with a guard and most of the people of the neare plantations came to welcome them, and brought and sent for divers days, great stores of provision as fat hogs, kid, venison, poultry, geese, partridges etc. So, as the like joy and manifestation of love had never been seen in New England. It was a great marvel that so many people and such store of provision could be gathered together at so few hours warning.

"II. We kept a day of Thanksgiving at Boston."

Governor and Mrs. Winthrop took up their residence on Main Street, now Washington, on the eastern slope of Beacon Hill. The frame of the house had been set up at Watertown but taken down and then removed to Boston. It was not a pretentious house, having but six rooms with lofts and garrets, but must have been fairly commodious as it held many notable gatherings. It stood until Revolutionary times, when it was torn down and burned for firewood by the British soldiery.

In this home, Margaret Winthrop spent the remainder of her life, and if we may rely on 


\section{$292 \quad$ Pioneer SIDothers of Eimerica}

the testimony of her family and neighbours, they were sixteen happy years. We are wont in these later days to pity these Puritan wives of New England but the chances are that our commiseration is largely uncalled for. Except in the first months in a few of the early colonies, it was not long before the colonists came to be surrounded by many of the creature comforts that they had left behind them. We must remember also that the women were as strong in the faith as the men and that they had the, to them, inestimable privilege of worship unmolested. The families were united and in the case, as in the Bay Colony, where whole congregations had emigrated together, the keen edge had been taken from the homesickness that comes from tearing away from old associations. Mistress Winthrop, who had seen for years the gathering storms of religious hate and persecution, and who had been separated from her husband much of the time, must have found in the new world much to bring peace and content to her mind. She had constantly with her her husband and all her children except her son Deane. Her life was a busy one, filled with the manifold duties of a New England 


\section{rulomen of Colonial Times}

housewife-duties differing but little from her duties as a rural housewife in old England. She had many cares, for her husband not only seems to have held court in his own house, but to have entertained his deputies and welcomed all visitors to his hospitable board. We gain a slight insight into the Winthrop household when in 1633 we find admitted into membership in the First Church of Boston, Elizabeth Wybert, William Browne and Thomasine his wife, all servants of "our brother John Winthrop, the elder." These were good honest country folk, from her own section of England, hired for service and recognised as part of the family. Later, there were other of her servants taken into Rev. John Wilson's church, showing that Margaret had fairly solved the question of domestic service.

And the wife of the Governor was not without good society. There were in the colony at an early day, not less than forty-five college men from Cambridge and Oxford and more than half of them lived with their wives in Boston. By I647 it was calculated that there were upwards of one hundred university men in the colony. In her sixteen years' experience of New England, 


\section{Dioneer SDothers of America}

Mistress Winthrop must in fact have come to know a most heterogeneous collection of persons. Ann Hutchinson, was a neighbour, living so near, we are told, that "they filled their pitchers from the same spring"; but the two women were so dissimilar in minds and mental processes that they could never have been intimate. Until Mistress Hutchinson and her "antinomianism" brought a schism in the church, Sir Harry Vane was a frequent visitor and, indeed, maintained for Margaret and her husband a warm and lasting affection. Another woman whom she knew was the able and intellectual Ann Hibbins, a sister of Deputy Governor Bellingham, a good woman but so stubborn in her convictions that Governor Winthrop had to order her whipped in jail for her contumacy. A regular visitor was Rev. Hugh Peter, the Regicide, father-inlaw of John Winthrop, Jr., who was to return to England and become Cromwell's chaplain, and finally to give up his life on the scaffold. Both Mistress Winthrop and her husband, we are told, were very fond of another frequent guest, Roger Williams, the brilliant, "conscientiously contentious" young divine, who was given to stirring up strife, but never in anger. 


\section{Tutomen of Colonial Times}

There was Captain Cromwell, the jolly and generous pirate, who loved best to come to Boston to scatter his money on shore, after the manner of sailormen from the beginning, and who embarrassed the Governor by bringing him a Sedan chair, valued at $£_{50}$, which the Governor did n't want, but finally used in settling an affair of state. To the Winthrops came also that dashing, unscrupulous vagabond, half hunter and trapper and half Governor of the French province of Acadia, Sieur Charles La Tour, and his wife, whose beauty and daring had already made her known at the Catholic court of France, as a Huguenot woman whose influence was to be feared. It would be interesting to know what Mistress Winthrop and her sister-in-law Lucy Downing, who was also her most intimate friend, had to say about these people. Probably Mistress Winthrop looked at them mainly through her husband's eyes, but not so Mistress Downing, whose letters, published in the Collections of the Massachusetts Historical Society, give evidence of a ready wit and quick discernment, as well as of education. Another "deare friend" of Mrs. Winthrop was her husband's daughter Mary, the wife of the eldest son of 


\section{Dioneer Mothers of Ëmerica}

Deputy Governor Dudley, who lived in Cambridge and seems to have been very close to the heart of her stepmother. A neighbour and a friend of long standing, they having crossed the seas together in 1630, was Ann Bradstreet, wife of Simon Bradstreet, afterward Governor, and daughter of Deputy Governor Thomas Dudley. Ann Bradstreet was "ancestor of the Channings, Buckminsters, the Danas, Wendell Phillips, and Oliver Wendell Holmes." Ann was herself a poet, the first of New England, having brought out in London in 1650, The Tenth Muse, Lately Sprung up in America, a collection of verses, most of which express more of vigorous thought and action than of poetry. She was an original character, very human and likable, but she must have needed all the prestige of having two governors in the family to have kept out of jail. Her poems breathe in every line, opposition to man's domination, quite in accord with advanced modern ideas, but which must have been almost as heretical in the Boston of that day as Ann Hutchinson's "revelations." Among other sentiments in her poems are these: 


\section{vxlomen of Colonial Times}

"I am obnoxious to each carping tongue, Who says my hand a needle better fits, A poet's pen all scorn I thus should wrong, For such, despite they cast on female wits, If what I say prove well, it won't advance, They '1l say 'twas stolen or else it was by chance."

Ann wrote of Queen Elizabeth:

"She hath wiped off the aspersion of her sex That women wisdome lack to play the Rex."

And again she says:

"Now say, have women worth or have they none?

Or had they some but with our Queen it's gone? Nay, masculines, you have thus taxed us long;

But she though dead will vindicate our wrong, Let such as say our sex is void of reason, Know 'tis slander now, but once 't was treason."

Ann Bradstreet bore her husband eight children and died at the age of seventy. Governor Bradstreet, who was still older, married again, but that was to be expected. Even John Winthrop was married to a fourth wife, Martha Coytmire, not more than a year after death had claimed Margaret Winthrop in I647.

Mrs. Winthrop was the mother of eight children, four of whom died in infancy. Of those to come to maturity, Stephen, the oldest, became Recorder and Representative in New 


\section{Pioneer Mothers of America}

England, and then, returning to England, became Colonel in the Parliamentary army and afterward Major-General. He left no male descendants. Adam, the second son, married a stepdaughter of President Dunster of Harvard. He left a son Adam, who in turn left a son Adam who became Chief Justice, and from whom was descended Professor John Winthrop, of Harvard, the astronomer and Revolutionary patriot. Deane, the third son, left no sons. Samuel Winthrop, the youngest son, married a Dutch lady and became governor of Antigua. His sons also died unmarried, though through the daughters there came a line of eminent descendants.

Margaret Winthrop, says her biographer, Alice Morse Earle, "had a life of hard work and of many cares, and she experienced entire loss of fortune; yet I think her life was a happy one, for there was one bitter cup she was never forced to taste-that of disgrace; and in all her sorrows and fears she was cheered and strengthened not only by an inspired religious faith, but by a love such as is the fortune of few women to arouse and retain; a love so thoughtful, so sheltering, that it might well prove to her, 


\section{rulomen of Colonial Times}

as her husband said, a symbol of the everlasting love of her Heavenly Father. Throughout her life she ever displayed traits of character, disposition, and faith that were most noble and beautiful, and that render her fit to stand as the emblem and personification of what I have learned to believe is one of the purest types of womanhood,- the Puritan wife and mother."

\section{Margaret Brent}

To the Catholic colony of Maryland, in the days of Lord Baltimore, there came a young woman of gentle birth, great beauty, and of a masterful daring. It was not a time when women were wont to figure in public matters, yet this woman was for years to exert a powerful and controlling influence in the affairs of the province, and it is writ in the records that she was the first woman in the world's history to demand the right of suffrage.

It was in the year I634 that Leonard Calvert, a younger brother of Sir Cecil Calvert, Lord Baltimore, and bearing his appointment as Governor of the province, brought to the shores of Maryland some 300 colonists, twenty of whom 
were men of wealth and position, and the others skilled farmers and handicraftsmen. In the party were Father White, a priest, who was to exert a most peaceful and kindly influence over the Indians of the little peninsula; Thomas Cornwalys, a sturdy soldier and loyal, "the Miles Standish of Maryland," as he was to be called in later days, and Thomas Green, a dull, weak, though honest man who was to succeed Calvert as Governor.

Four years later, in 1638 , the year that saw Ann Hutchinson, with a babe at her breast, driven into the wilderness by the ministers of Boston; the year that saw Annetje Jans and her little brood of Roelofsens floating down the Hudson to the small farm that Wouter von Twiller had given them on Manhattan Island; and not far from the time that Priscilla Alden's daughter was to round out a pretty New England romance by marrying the son of Captain Miles Standish, there came another shipload of colonists, a part of whom were gentlefolk and the others farmers and skilled workmen of a class highly desirable in a new country. In this party were "Margaret Brent, a gentlewoman," and her sister and two brothers, Giles 


\section{tromen of Colonial Times}

and Fulk, and their "servants," five men and four women,-in reality settlers who had bound themselves to labour for from three to five years for their passage and their establishment as homesteaders. The ship, after its long and tirescme voyage arrived in early November, and the colonists first saw the shores of the Chesapeake brilliant in the beauty and glow of Indian summer. Orioles and scarlet tanagers, bluejays and ricebirds, piped and chattered in the forests, and wild flowers still bloomed, vying in brilliancy of colouring the red and gold of the autumn foliage and the purpling clusters of wild grapes that hung in festoons from every tree. It was, indeed, a land fair to look upon, and gave grateful promise of milk and honey to the wearied voyagers.

Governor Calvert gave warm welcome to Margaret Brent and her sister and brothers. Giles Brent was appointed a member of the Council and was advanced from one position of trust and honour to another, and was even made acting governor during Calvert's absence, when he was called to Europe in I643. The Brent family long played a prominent part in the affairs of the colony. They took up land on 


\section{Dioneer Mothers of America}

Kent Island, almost immediately after they landed, and built manor houses and entered actively into business.

In an isolated community where unmarried men exceed unmarried women by nearly two to one, there is little chance of a maid going unmated unless she herself so wills. So it was in Maryland. There was scarcely an unmarried cavalier from Governor Leonard Calvert himself down through the list of his landed gentry who was not ready to throw his name and fortune at the feet of fair Margaret Brent. But that cold beauty favoured no one suitor more than another, treating all with a tact that held them her friends.

And ever was she the busy woman of affairs. She became learned in the English law, especially wise in the statutes covering estates and decedents, in which the province was even more English than the tight little island itself. Indeed one of the two courts-baron, of which records have been discovered, was held at St. Gabriel Manor, the estate of Margaret Brent. She and her sister took up other lands, founded other manors, sent back to England for colonists and settlers, seed, stock, and implements, and 


\section{ralomen of Colonial Times}

in other ways managed their property with masculine ability. Through the musty old records we find traces of her, buying and selling property, registering cattle marks for herself, and at other times as "acting attorney for my brother." Altogether she seems to have been entirely too busy with her land operations, her stock and grain raising, and her other business ventures to think of love making, though Governor Calvert and all the gentlemen of his cabinet might importune her.

But though loath to be wooed and won, the fair Mistress Brent ruled royally in her little court of admirers in the now forgotten city of St. Mary's. Her influence was great and always for the good of the colony, and for the advancement of that single-minded, publicspirited, and upright executive who called her "cousin" and treated her with the deference shown to a queen. And she seems to have been worthy of his homage. She was a woman of brains and courage. She had imagination and executive ability. She knew her little community and how to manage it and its affairs with infinite tact. Governor Calvert's treatment of 


\section{Dioneer Mothers of America}

the Indians was as just and humane as that of William Penn, some forty years later, and this policy is said to have been largely influenced by Mistress Brent. She was a stanch Roman Catholic, but always she stood for freedom of religious thought and worship, and she is credited with having done much to secure the passage of the toleration act, which, though Governor Calvert did not live to see enacted, he had worked long to bring about.

It is a great misfortune that the records are lost that might tell us how and where Margaret Brent passed her time the while William Claiborne aided by the pirate Ingles seized and held the Isle of Kent, though it was clearly within the grant of Lord Baltimore. That was in I644, and Governor Calvert, who had just returned from England, was forced to flee into Virginia, with many of his loyal Marylanders. Whether Mistress Brent was of these or whether she stayed and guarded her property is not known, though the latter course is most in keeping with what we know of her. It was two years before Governor Calvert was able to put down the rebellion and again take up his residence in his own colony. Then he came broken in health, 


\section{Tatomen of Bolonial Times}

though not in spirit, and in the summer of 1647 he lay upon his death-bed. Around him were gathered a few of his most faithful friendsThomas Green, and one or two others of the Governor's Council, Father White, and Margaret Brent and her sister Mary. Calling the attention of all present that he was about to make his last will and testament, Calvert named Thomas Green as his successor as Governor, and then, pointing with his emaciated forefinger to Margaret, with confidence and admiration if not with love, he said: "And you, Margaret, I make you my sole executrix. Take all and pay all."

After these terse and laconic instructions, it is said the dying man lay back on his pillow and asked that all should leave the room "except Mistress Brent." What passed between them at this final parting no one knew but Mistress Brent, and she was not one whom it would be pleasant to ask, but it was most evident that in her he reposed the utmost confidence, and most faithfully was his trust fulfilled.

Mistress Brent at once took charge of the house and estate, inventoried his property and his obligations, which, after the debts were paid, 


\section{Dioneer SDothers of Emerica}

amounted to only "one hundred and ten pounds sterling." But Leonard Calvert's property was not all he bequeathed to her when he said, "Take all and pay all," according to Mistress Brent's way of thinking. She made claim that since she had been appointed executrix of Leonard Calvert, she had the right to succeed Leonard Calvert as Lord Baltimore's attorney, and in that position to receive the profits and pay the debts of his estate and to carry on all of Lord Baltimore's business in the province.

Some of the colonists objected to this, having doubts of the legality of the claim, but Mistress Brent, ever dauntless of opposition, applied to the Provincial Court for an interpretation of her rights. Knowing of her powers of persuasion, we can well understand that the Court ruled entirely in accord with her wishes

Margaret Brent was now not only mistress of Governor Calvert's mansion, but by a decree of the Provincial Court she had become attorney for Lord Baltimore, with control of all the rents, issues, and profits of his estate. Lord Baltimore did not know anything of this, but that did not disturb Mistress Brent.

Now, however, she was to allow her audacity 


\section{relomen of Colonial Times}

to carry her farther than ever before and to meet with her first defeat. She decided that she had as good a claim as any one else to a vote in the General Assembly. Leonard Calvert, as attorney for the proprietary lord, had the right to vote, and now that Leonard Calvert was dead and she was acting attorney she claimed the right to a vote. Furthermore, she claimed that as Leonard Calvert's executrix she was entitled to another vote. In other words, she demanded representation for a foreign lord who had never authorised her to act for him, and another for a dead man whose only instructions to her had been: "Take all and pay all."

It was in January, I648, that Mistress Brent made this astonishing stand for woman's rights. She had ridden her horse four miles from her home to Fort St. John, where the General Assembly met, and there was the light of a high purpose in her eye when she entered the assembly room. The members were expecting something of the sort and, while they were determined not to grant her demand, were at a loss how they could well refuse. And Governor Green was the most disconcerted of all. Vainly the 


\section{Dioneer Motbers of Emerica}

Assembly hedged her about with rules and precedents, and tried to prevent her speaking. But speak she did, and almost carried the assemblage off its feet with her persuasive reasoning, and but for the sudden-found firmness of Governor Green, ever jealous of her power, the planters might have granted her request. It had been said throughout the Colony that Calvert would have done better had he made Margaret Brent his successor as Governor and appointed Thomas Green as his executor. Anyway, the usually vacillating Thomas braced himself for action and, as the musty records show, declared that "the said Mistress Brent should have no vote in the house."

"The said Mistress Brent," as might have been expected, made a most vigorous protest, objecting vehemently to the action of the Assembly. In the archives may be found this entry:

“January 2I, I647-48, Came Mrs. Margarett Brent and requested to have a vote in the howse for herselfe and voyce also, for that att the last Court 3rd Jan. it was ordered that the said Mrs. Brent was to be looked upon and received as his Ldps. Attorney. The Govr. denyed that 


\section{Tramen of Colonial Times}

the sd Mrs. Brent should have any vote in the howse. And the sd Mrs. Brent protested against all proceedings in this present Assembly unlesse shee may be present and have vote as aforsed."

It was but a short time after this that Governor Green had to come to Margaret Brent for advice and help. Governor Calvert, when he raised troops to put down the insurrection headed by Claiborne and Ingles, had promised to pay them in full out of his Lordship's estate. His death had prevented his making good this promise, and now Governor Green found himself facing a mutiny in his army. Mistress Brent was equal to the emergency. She at once sold enough cattle off his Lordship's estate to satisfy the claim, and herself addressed the half-starved men and quieted the insurrection.

Lord Baltimore knew nothing of the appointment of the woman to act as his attorney for some months after it had been done, and then not from her friends. He was led to believe that she was an officious and meddlesome person and is said to have written "tartly" and with "bitter invectives" to the General Assembly. This body, the same that had refused to allow 


\section{Dioneer SDothers of America}

her a vote, sent a spirited reply to Lord Baltimore in praise of Margaret Brent and her wise conduct. They told his Lordship that they did "verily believe it was better for his own advantage and the colony's safety that his estate was in her hands than in any man else's." They said further that the soldiers would never have treated any other "with that civility and respect which they had always shown her," and when at times they were "ready to run into mutiny," she was the only one in the colony who was able to pacify them. "All would have gone to ruin," they wrote, if Mistress Brent had not been proclaimed his Lordship's attorney by order of the Court. The letter ends with a dignified protest that Mistress Brent deserved "favour and thanks from his lordship rather than all those bitter invectives," which he had been pleased to express against her.

In other words, the Assembly which refused her a vote defended her against the lord of the colony and declared her to be the ablest "man" among them.

Margaret Brent died at St. Mary's in I66I, in the sixty-first year of her age, honoured and respected from one end of the province to the 


\section{Vulomen of Colonial Times}

other. To the end of her days she continued to lead a life of energetic activity-always a fearless, vigorous, but dignified personality. She might have had graven on her tombstone these words, written of her near two centuries later by a historian of her own State:

"Had she been born a queen she would have been as brilliant and daring as Elizabeth; had she been born a man she would have been a Cromwell in her courage and audacity."

\section{Mary Jacqueline La Tour}

Frances Mary Jacqueline La Tour was a heroine of Colonial days and though the daughter of an alien race and not even of our own colonies, the story of her sorrows and her struggles, her beauty and bravery, and the picturesque setting in which her life was framed, have won for her a sympathy as romantic and lasting as the metrical tale the poet Longfellow has wrought about the memory of that other Acadian maid of later years. It is a story of primeval passions, unbridled ambition and avarice, of unscrupulous men in a wild and lawless country, of deep-laid plots, of bloody deeds and quick revenge, but ever the character of the proud, high-spirited 


\section{Dioneer Mothers of America}

young Frenchwoman stands out clear cut, clean, and wholesome-a devoted wife and mother, a loyal friend, and an open and fearless enemy.

She was the wife of Sieur Charles St. Étienne de la Tour, who held feudal rights over a large section of Acadia, along the St. John River, with a fort that bore his name, high on the headland overlooking the Bay of Fundy. The fort, built of stone and inclosed by palisades, was garrisoned by a formidable force of hardy Frenchmen and Indians, voyageurs, hunters and trappers, rivermen and seamen-trusty men who balked at nothing so long as it lay within their master's wishes. Twenty brass cannon were mounted, ready to defend the stronghold, and true men and great guns were needed by the Governor to maintain his rights and hold the territory over which his followers hunted, fished, and trapped. For Sieur Charles La Tour was a great trader as well as soldier. To Fort La Tour came the peltry from the lower St. Lawrence and the rivers and lakes of Maine, then a part of Acadia, and fish from a thousand miles of coast. Twice a year there came a ship from France to carry back peltries and dried fish and to bring such supplies as were demanded 


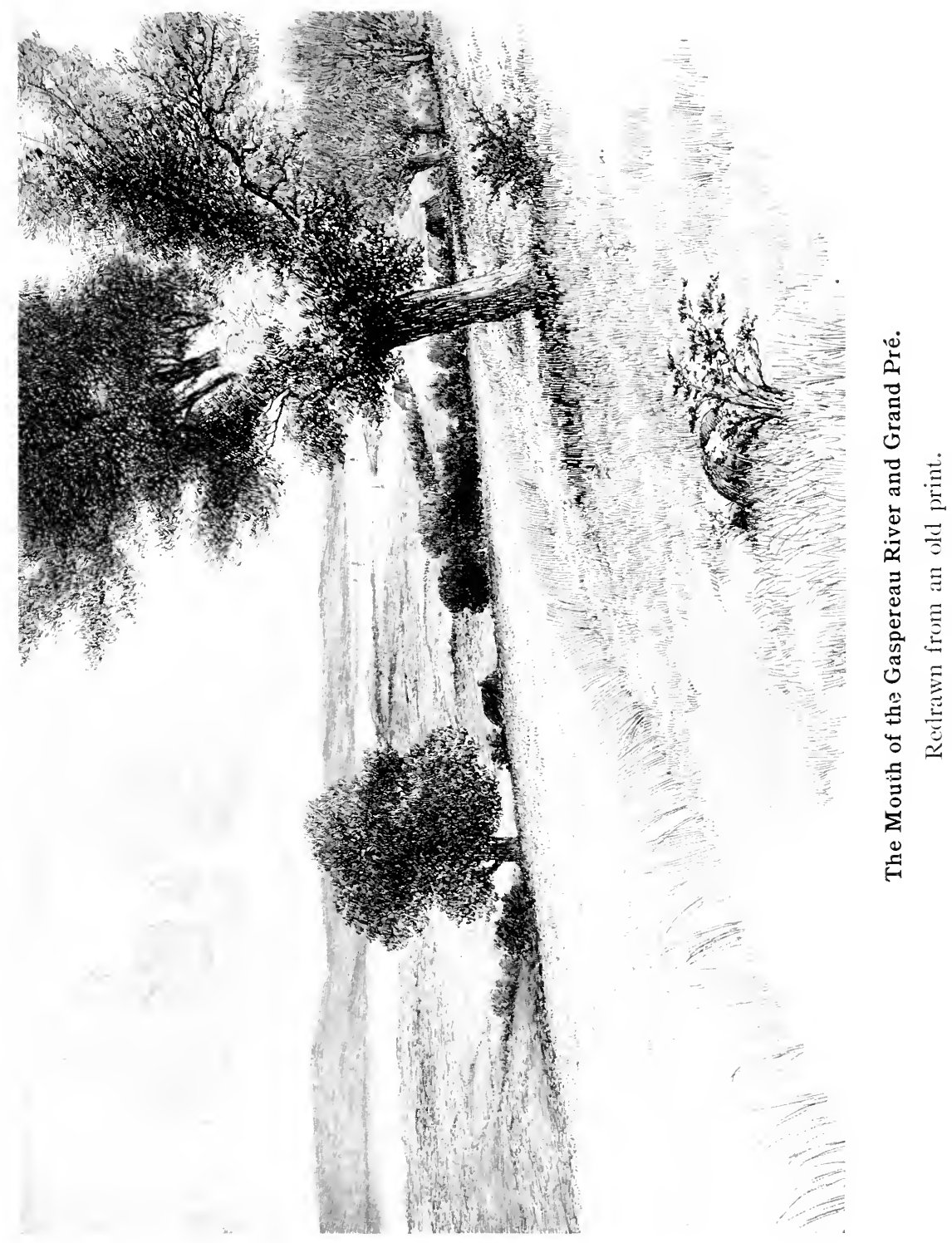





\section{ruomen of Colonial Cimes}

by his rude retainers or the semi-barbaric luxuries of dress and furnishings that he was wont to lavish upon his wife and home. He was a bold, shrewd man, a master of discipline, but as unscrupulous as he was daring. $\mathrm{He}$ called himself a Huguenot but could play the Jesuit as easily when it suited his purpose, and indeed he maintained two Jesuit priests among his retainers. He was a man of great enterprise, a finished courtier, but loyal to no one but Sieur Charles La Tour.

In 1620 , or thereabouts, he had married Francis Mary Jacqueline, a Huguenot maid of an old but impoverished family in Rochelle-a family that had fought for religious liberty on many a bloody field. She was a woman of rare beauty and of splendid spirit and energy, a fitting mate for the daring soldier-trader. Her husband was more than fond of her and often laid upon her pretty shoulders burdens ill calculated for one of her sex to bear. An expert with a gun or a salmon spear, she could row a boat like a sailor or paddle her canoe like an Indian. She had accompanied her husband to his trading posts on the Penobscot, on Cape Sable, and at various other points in Nova Scotia and New 


\section{Dioneer SDotbers of America}

Brunswick, and had grown to love her wild new home.

Yet, withal Mme. La Tour, within doors, was another woman-a soft-voiced woman of gentle breeding, who prayed daily and devoutly in her own chapel, who looked after her little children, cared for her wildly beautiful home, and taught her Indian people many of the ways of civilisation, and they were in turn ready to do or dare anything she might demand.

Sieur Charles La Tour had a rival, living across the waters in the colony of Port Royal, Seigneur D'Aulney Charnise, like himself a soldier-trader. But they were rivals in other ways. Both men held the King's commission as his lieutenants in Acadia. Whether this came from accident or design cannot be known. Charnise was a Jesuit, a crafty but daring man who had learned the ways of courts and courtiers at the French Court while La Tour was learning woodcraft and war craft in the forests of the new world with the adventurer Biencourt. Also Charnise was a friend of Richelieu and it was a day of plotting and double-dealing at the French court. Anyway Charnise was trying to gain wealth from trading in the dried fish 


\section{tollomen of Golonial Times}

and peltry of Acadia and looked with envious eyes upon La Tour. The latter was too firmly intrenched in his fort, his wild but well trained retainers, and his trading posts to fear personal attack, and of too open a nature to fear underhand work at Court until there came an order for his arrest signed by the King. La Tour laughed at Charnise when the order was thrust in his face, and laying his hand on the hilt of his sword said "Take me," at the same time giving a meaning smile at his stone walls and bristling cannon and his fierce-faced followers.

Charnise knew that he had not the force nor the ships to attack Fort La Tour and he withdrew with the best grace he could master but at once sent word to France of his rival's insubordination. Sieur Charles La Tour, without a commission and insubordinate, was but a rebel, and soon he began to realise the fact that while he might never have to fear Charnise, standing alone, Charnise backed by a French man-of-war would soon batter down his fort and at last land him in a French prison. He could have no hope from the French Court, but at Rochelle, the home of his wife's family, there might be friends who would come to his aid. So he hastened 


\section{8 Dioneer Motbers of America}

a messenger to Rochelle and waited. The time came when the Clement, from Rochelle should arrive with supplies and reinforcements. One morning La Tour and his wife, looking out over the waters, saw three ships and several smaller craft gliding into the harbour before Fort La Tour. It was Charnise come to attack him. La Tour acted quickly as ever. Before Charnise had landed his five hundred men every soldier in Fort La Tour was at his post and among them Lady La Tour as usual, directing the cannonading, even to sighting the guns. There came a wild dash by Charnise and his men up to the embankment, only to be met by a fierce volley from the fort. Half an hour later Charnise retired bearing his dead and wounded while within the fort there was general rejoicing, for no one had been hurt and the men, one and all, hated and feared Charnise.

But Charnise had not been beaten. He had only retired to his ships to establish a blockade and leave hunger to do what his followers could not. Charnise knew that the Clement was expected with supplies and he planned to keep the ship from entering the harbour. His plan worked well, only he had not planned far enough. 


\section{wamen of Colonial Times}

The Clement came and was stopped because of the blockade. The La Tours had spied the vessel and signalled the captain. One dark night two or three days later La Tour and his wife slipped quietly out of the fort and in a rowboat when the tide was running out dropped down and boarded the Clement, which immediately weighed anchor and sailed for Boston. The Governor of Acadia was going to the brisk and thriving town on Massachusetts Bay for aid in protecting his own.

It was in June, I643, that the Clement reached Boston. Her unexpected arrival gave a great scare to the good people of the Puritan town. As Governor John Winthrop afterward wrote, the Governor of Acadia " might have gone and spoiled Boston and taken her ships and sailed away without danger of resistance." But the Governor of Acadia had no such warlike intention. As he was about to land, one of his men recognised, in a middle-aged woman on the banks, a Mistress Gibbons, wife of a shipmaster, whom he had once met with her husband. The good woman had come down from the town above to look after her garden, and was very much frightened. La Tour manned his shallop and 


\section{Dioneer Motbers of America}

rowed toward her, anxious to speak. She fled as if all the witches were after her, running directly to the summer home of Governor Winthrop. It was thus that the beleaguered Governor of Acadia met the Governor of Massachusetts Bay Colony. Mingled with apologies and protestations to the frightened Mistress Gibbons, M. La Tour made a most respectful and brotherly salutation to his brother of Massachusetts Bay and frankly told his story. He said that the ship Clement had been sent to him from France but his enemy Charnise had blockaded the mouth of the river St. John and would not let her in. He himself and wife had stolen away and had come to ask of "the good kind people of Boston" aid against the wicked Charnise. La Tour was a plausible man and Governor Winthrop was impressed with him. The La Tours and Mistress Gibbons dined with the Winthrops and both the Governor and Margaret Winthrop his wife were greatly taken with the brilliant and beautiful young Frenchwoman. The La Tours remained in Boston until about the middle of July, lodging at the house of Captain Gibbons, and we may be sure that the visit of the feudal chief and his wife 


\section{Wulomen of Colonial Times}

was the cause of a great deal of stir in the Puritan town. There was little criticism of their actions. Governor Winthrop himself records that "he came duly to our church meetings and always accompanied the governor to and from thence." What the dark-faced La Tour thought of Dr. Cotton's thundering eloquence we can never know but his appearance was most circumspect, though the question of assisting the Acadian Governor to maintain his rights was not to be settled without argument. The Governor and magistrates debated it for days and with considerable heat and much reading of the Bible and long prayers. Finally the everprudent New Englanders declined to give direct aid to the La Tours, but allowed the French Governor to make such arrangements with private parties as best he might. That virtually sanctioned the shipmasters and fighting men in driving the best bargains they could with $\mathrm{M}$. La Tour and ended by his securing from Captains Gibbons and Thomas Hawkins four ships, manned and equipped.

When the Clement and her Yankee convoys rounded the headland into St. John River they found Charnise still holding the blockade-- 


\section{2 IPioncer SiDothers of America}

guarding the lair from which the fox had escaped weeks before. La Tour had outwitted him and was returned, revengeful and eager for battle. Charnise quickly hoisted sail and started for his stronghold in Port Royal, La Tour and his fleet close behind. Charnise ran his vessels aground in his harbour and he and his force turned at bay, inside their stronghold. La Tour was for pressing his advantage and destroying his rival, but the Boston captains had no particular enmity against Charnise and refused to join in the siege, but gave leave, however, to such of their men as wished to volunteer. A charge was made in which each party lost three men, and La Tour captured one vessel loaded with moose and beaver skins. It is a matter of record that the thrifty men of Boston, though they had refused to go into the fight, took their half of the booty. ${ }^{\mathrm{I}}$

Sieur Charles La Tour was now in command of the situation but his position was anything but secure. Of Charnise he had no fear, but of Charnise backed by the French government, or such a part of it as he might secure, was dangerous. He still believed that his wife's friends, the Rochelois Huguenots, would come 


\section{runomen of Colonial Times}

to his aid and trusting to her cleverness he dispatched her to Rochelle. But Charnise was before her and at the French Court he denounced her as a traitor and procured a warrant for her arrest. Her friends learned of this and warned her in time for her to make her escape to England. There, she freighted a ship with provisions and munitions of war. The ship was owned by Alderman Barkley and was commanded by Captain Bailey. Mme. La Tour stipulated that the utmost possible haste must be made and lost no time in starting back to America. As a fellow-passenger on the trip went Roger Williams, who was returning to Providence with his charter and commission as Governor of Rhode Island. The pronounced though liberal religious views of the brilliant young Frenchwoman were so nearly in accord with his own, that the two became warm friends. Captain Bailey, for the sake of trading with the Indians, deflected from his course and the impatient woman found herself weeks behind the time she had planned to gain her home. It is needless to say that the lady La Tour did not fail to acquaint him with her feelings in regard to this. As they sailed into the Bay of Fundy 


\section{Dioneer Mothers of Almerica}

they sighted a French ship. As they neared it Mme. La Tour recognised Charnise on deck. In a few minutes she was hidden in the vessel's hold and she could overhear Captain Bailey deny that he had any French passengers aboard and declare that his vessel was bound for Boston. She was saved but her anger at Captain Bailey again flamed up. Had he lived up to the terms of agreement which she had made with him and Alderman Barkley she would have been home before Charnise. If Fort La Tour was taken, she held, it would lie at the door of the British captain. However, there was nothing to to do but to go on to Boston as Charnise was cruising about to intercept any vessel that might be bound for St. John.

Her impatience was not so great but that she found time in Boston to bring suit against Barkley and Bailey before a magistrate and jury and was awarded damages in the sum of two hundred pounds, and the vessel was held until the amount was paid. Then Mme. La Tour loaded her goods on three ships which she hired and was soon landed in the harbour of Fort La Tour. For a time there was peace and plenty at Fort La Tour and the voyageurs and Indians 


\section{Tramen of Colonial Times}

pursued their wonted vocations, light at heart as the birds of their own forests. But ever there was the dark and vengeful Charnise with his commission and his warrants for the arrest of both of the La Tours, and Sieur Charles realised that it was only a question of time, unless he added to his forces, before Charnise would crush him. So long as Charnise should live and his ships of war were anchored in Acadian waters there was no peace. He must again try to gain reinforcements from Rochelle. This time he went himself, leaving Mme. La Tour in command. There were two monks at Fort La Tour whom the master had kept out of allegiance to King Louis. They were unfriendly to the Huguenot woman, and when he had gone, they went at once to Charnise and reported the condition of affairs at the fort, the paucity of men and munitions. Charnise felt that the time had come for him to strike. For weeks the war-ships of Charnise patrolled the mouth of the harbour waiting to catch La Tour. Then one February morning, in 1645 , the vessels of the fleet could be seen closing in on the fort and the assault began. Mme. La Tour was ready for the fray; every gun and cannon was manned and the woman herself 


\section{Dioneer Mothers of Almerica}

stood on one of the bastions, in full command. All day the battle raged and before night two of Charnise's men were killed and thirteen were badly wounded. Fort La Tour and its defenders had suffered no injury. The boats in the harbour were badly damaged. Charnise had to sail them to a place of safety and then run them aground to keep them from sinking. Charnise did not renew the attack, but he kept ceaseless patrol over the mouth of the harbour and ever grew his hatred of the brave woman who had beaten him. From February until April this continued. Mme. La Tour and her soldiers realised that there was little or no hope for them, but with the French spirit they laughed and made light of their hardships, though they were reduced to dried codfish and corn-meal.

"Then," writes an Acadian historian, "one spring night came the beginning of the end." There was heard "the rattling of cables" and the "splash of lowering boats in the harbour." Charnise was preparing for another attack. It came at dawn and from the landward side and the weaker. The enemy were met with such a wild dash of desperate fury that they were driven back. For three days the fight 


\section{Txhomen of Colonial Times}

went on and Charnise had gained no advantage save one that he did not himself realise. That was the worn-out and wasted condition of the half-starved little band within the walls. They had no hope, but the bravery and determination of their woman leader held them, clear-headed, resolute, courageous. There was a short respite. On Easter morning, Mme. La Tour and her scant garrison were at prayers in her little chapel. Suddenly there came a rush of feet and a wild outcry of exultant men. Charnise had bribed a Swiss guard of her garrison to open the gate of the palisades. Charnise's soldiers had only to scale the inner walls to capture the fort. Here again the dauntless heroism of the woman held her men like a solid rock. They thronged about her and as her clear resolute voice shot forth her commands fought with a desperation that broke the onslaught and again drove back the besiegers. Charnise was led to believe that her forces were much larger than they were, and raising a flag of truce, offered "Lady La Tour honourable terms." To save her broken but devoted remnant of a garrison, Mme. La Tour put her name to articles of surrender. Here came the black villainy of Charnise-the tragic close of the 


\section{8 Dioneer Mothers of Emerica}

career of Jacqueline La Tour. When Charnise came to look upon the little handful of halfstarved men who had held him at bay, he was swept away by a passion of mortification and anger. He turned to the woman and tearing up the capitulation ordered her followers hanged, one after another, while she with a rope around her fair neck was compelled to witness the scene, with the expectation that she would follow in their footsteps. From that hour, Mme. La Tour was a broken woman. She never rallied and when death came to her a few weeks later at Port Royal, where she was imprisoned, it must have brought welcome relief.

It adds but little to the story to tell of the death of the dark and vengeful Charnise, who fell into the river at Port Royal shortly afterward and was swept away, nor of the irony of fate that brought back La Tour in time to seize the belongings and assume the authority of his old enemy and eventually to wed the sorrowing widow of Charnise.

\section{Martha Pitkin Wolcott}

It would scarcely have surprised Martha Pitkin, handsome, vivacious, twenty-two, and 


\section{Tulomen of Colonial Times}

fresh from London in I66I, to have known that she was a source of interest to the young men of Windsor. But she would have been vastly astonished to have known that this interest was shared by the aged councillors and head men of that colony. But so it was, for we have the record of Dr. Thomas Robbin's diary, that"This girl put the colony in commotion. If possible she must be detained; the stock was too valuable to be parted with. It was a matter of general consultation what young man was good enough to be presented to Miss Pitkin."

And so the wise fathers of the colony put their grey heads together and held much grave argument, carefully considering this one and that, balancing this one's attainments against that one's possessions, until at last "Simon Wolcott, of Windsor, was fixed upon and beyond expectation succeeded in obtaining her hand."

That one of the five sons of Henry Wolcott should be selected, was but natural, for Henry Wolcott "after the pastor . . . was the most distinguished man in Windsor." He held an estate in England that brought him a "faire income" and he had equipped and entered upon an expedition to the New England colonies, 


\section{Pioncer SDothers of Almerica}

which he considered "a mission of civilisation and Christianity." $\mathrm{He}$ was one of the first permanent settlers in the town of Windsor, was a member of the first General Assembly held in Connecticut, and was elected to the House of Magistrates in I643, which office he held until his death. And Simon Wolcott, the youngest and handsomest of the five sons, a widower-his young wife had died at the age of eighteen, a month after her marriage-living on his own estate at Windsor, was as good a matrimonial prospect as the Colony had to offer, and Simon was evidently nothing loath to attempt the plans of the elders. But there is a tradition that Simon was not the only one of the five Wolcott brothers willing to lay his affections and estate at the feet of the fair English maid, and that the choice of which should be the first was settled between them by lot. How this was done is told by the poet Charles Knowlton Bowles, as follows:

"He took his brother's hand and said:

'Where we may not go on together You shall go first, and all my prayers Shall plead for you.' Then neither spoke. The smell of pine trees filled the air, 


\section{ranomen of Colonial Times}

And flowers beyond held waiting cups

Toward the grey sky.

" No, Simon, you have loved as I, And which of us could serve her best

For this world's happiness and that

To come, God knows, and his own will

Shall make decision. I will hold

This sweet wild rose and this poor weed

Behind me, one in either hand,

And he whom God knows would be best

For her, may he win her as he shall choose the rose.'

"The moon came full

Above the ominous clouds,

And from the boughs that swayed and swung

Across the narrow way, the birds

Looked out and twittered in the light.

The first house that foretold the town

Beyond, stood dim beside the road;

No face looked out as these two men

Rode by, one wavering 'twixt joy

And pity, with the wild sweet rose

That he had drawn pressed close upon

His beating heart, and one benumbed-

A weed left in his outstretched hand."

Just how far the poet drew upon his imagination is immaterial, but the fact remains that when Simon came a-wooing, Martha, who had come to the colony with the avowed intention of persuading her brother William to return with her to England, changed her plans and elected 


\section{Dioneer Mothers of America}

to remain herself, and the records show that Simon Wolcott married Martha Pitkin, "late of England," October I7, I66r.

William Pitkin, a brother to Martha, and the first of the name to come to this country, arrived in Hartford in the year I659, and began teaching school shortly afterward. In the spring of I66I, he bought a tract of land on the east side of the Connecticut River and began to clear it for farming; while this same year came his sister Martha from London, with the intention of taking the young man back with her to England.

It is also said that Miss Pitkin, who had left a brother, an officer in the royal army, when she saw her scholarly brother William working like any labourer on his plantation, exclaimed: "I left one brother serving his King, I find the other brother serving swine." This same brother whom she found "serving swine" was appointed attorney for the Colony in I664 and was a member of the General Court, and a prominent and honoured citizen for many years.

For the first ten years of their married life Simon Wolcott and his wife Martha lived upon his estate in Windsor, and during this period five children were born. In I67 I, Simon Wolcott 


\section{Vuromen of Colonial Times}

sold his Windsor farm and removed his family to a grant of land which he had received in Simsbury, but after a few years the outbreak of King Philip's War and the subsequent attacks of the Indians upon the settlers of that section forced him to return with his family to Windsor.

The story is told that Simon, upon receiving word of the approach of the Indians upon this occasion, hid his wife's pewter dishes in the swamp near by, concealing them so well that neither he nor any one else was ever able to find them. He remained in Windsor for several years, but found the settlement unprofitable, and in I680 removed to a tract of wild land which he owned on the east side of the Connecticut River, at what was known later as South Windsor.

The following quaint extract from the private journal of Roger Wolcott, the youngest son of Martha Pitkin Wolcott, gives us this record of the family at that time.

"In the year 1680 my father settled on his own land on the east side of the river there. We had neither Minister nor school, by which it hath come to pass that I never was a Scholar in any school a day in my life: My parents 


\section{Dioneer Mothers of America}

took great care and pains to learn their children and were successful with the rest but not with me by reason of my extreme dullness to learn. On Sept. II, I687, dyed my hon ${ }^{d}$ father in the $62^{\mathrm{d}}$ year of his age. It was just before the coming of Sir Edmund Andross. It was generally expected that persecution for religion would soon ensue: it filled him with agonizing fears and excited his fervent prayers for deliverance, but God took him away from the evil he feared to come."

Two years after the death of her first husband, Martha Pitkin Wolcott married Daniel Clark, sometime secretary of the Colony, returning to Old Windsor with her younger children.

Left with an estate that was in debt and but partially cleared and with a large family of children to provide for, the widow of Simon Wolcott must have had her hands very full indeed, during the two years that intervened between the death of Simon Wolcott and her marriage to Daniel Clark. Roger Wolcott, her son, speaks of this period in his diary and adds, "but we never wanted," a tribute to the unfailing energy and capability of the widow.

Of the personality of Mistress Wolcott we 


\section{Tramen of Colonial Times}

have no written record, other than that already given-brief glances at her as maid and mother; but the judgment of the wise men of Windsor who decided that "the stock was too valuable to be parted with" seems to have been amply vindicated, for few women in Colonial history had as many illustrious descendants as did Martha Pitkin.

Roger, her youngest son, in spite of his selfconfessed "extreme dullness to learn," held many high positions, a record of which we have from his own journal.

"In I707 I took my first step to preferment, being this year chosen selectman of the town of Windsor. In the year I709 I was chosen a representative from that town in the General Assembly. In I7 Io I was put on the Bench of Justices. . . In the year I7II I went on the expedition against Canada, Commissary of the Connecticut Stores. . . . In I7I4 I was chosen into the Council. . . . In the year I 73I I was appointed judge of the County Court. In the year 1732 I was appointed one of the Judges of the Superior Court. . . . In the year I74I I was chosen Deputy Gov ${ }^{\mathrm{r}}$ of this Colony and appointed Chief Judge of the Superior 


\section{Pioneer Mothers of Almerica}

Court. In the year I745 I led forth the Connecticut troops in the expedition against Cape Breton, and receiv ${ }^{\mathrm{d}}$ a commission from Gov ${ }^{\mathrm{r}}$ Shirley and Gov ${ }^{\mathrm{r}}$ Law for Major-General of the Army. I was now in the 69th year of my age and the oldest man in the army except the Rev ${ }^{d}$ Mr. Moody. . . . In the year I750 I was chosen Governor of the Colony of Connecticut."

Roger Wolcott married his second cousin, Sarah Drake, in I702, and of this union there were sixteen children born, the most notable of whom were the sons Erastus and Oliver. Erastus's Revolutionary record is given briefly by Stiles as follows:

$\mathrm{He}$ was "repeatedly representative to the General Assembly; \& speaker of the Lower House; Justice of the Peace; Judge of Probate; Chief Judge of the County Court; Representative in United States Congress; Judge of the Superior Court; Brigadier-General of Connecticut troops in the Revolutionary War: in the spring of I775 was sent, with Rev. Samuel Johnson, from the Connecticut Legislature to treat with Gen. Gage then in command of the British troops at Boston, and to ascertain, as far as possible, the designs of the British, with a view to an 


\section{ruomen of Colonial Jimes}

immediate preparation for the worst events, an interview in which they gained only specious and delusive promises of peace. $\mathrm{He}$ was commissioned Colonel in 1775 , and in 1776 he was appointed to the command of a regiment of Militia, with which he joined the army then investing Boston, under Washington: from thence he proceeded to New London, where he superintended the erection of fortifications and, with his regiment, garrisoned Forts Trumbull and Griswold during the summer; appointed in December, I776, as Brigadier-General, he served at and around Peekskill, N. Y. He was a firm patriot and an able advocate for the liberties of his country; and Yale College, in recognition of his personal worth and public services, bestowed on him an honorary degree. . . $\mathrm{He}$ was noble-hearted and generous; with no ambition for public life, accepting such offices as were offered him from a simple and sincere sense of duty."

Oliver Wolcott, as had his father before him, held many public offices. In 1776 he was a member of the Continental Congress and signed the Declaration of Independence. Upon his return to his home in Litchfield he took with 


\section{Dioneer Mothers of America}

him the gilded lead statue of George III., which had stood on Bowling Green in New York, until torn down by the patriots at the beginning of hostilities. He had the statue conveyed to his home, where with the assistance of his family and "sundry persons" it was converted into bullets for the army. ${ }^{2}$

The General Assembly of Connecticut appointed him a Brigadier-General in 1777 , and after sending several thousand men to aid General Putnam, he headed a force of four hundred volunteers who joined the army under General Gates. Here he took command of a brigade of militia and served against Burgoyne.

It was Oliver Wolcott of whom Barlow wrote:

"Bold Wolcott urged the all-important cause, With steady hand the solemn scene he draws;

Undaunted firmness with his wisdom joined, Nor kings nor worlds could warp his steadfast mind."

That Oliver Wolcott gave not only his services to the cause of freedom but supported it in any way possible is well known and we have the following written by Samuel Wolcott:

"Every dollar that could be spared from the maintenance of the family was expended in raising and supplying; every blanket not in 


\section{Tolomen of Colonial Times}

actual use was sent to the Army, and the sheets were torn into bandages or cut into lint by the hands of his wife and daughters. . . . From the beginning to the end of the Revolutionary War, he was constantly engaged, either in the Council or in the field."

Oliver Wolcott served as Lieutenant-Governor of Connecticut from 1786 to the spring of 1796 , when he was chosen Governor, which office he held until his death, which occurred in the December of that year.

Oliver Wolcott's son Oliver was also a Governor of his State, and his grandson, Frederick, twice refused the Governorship on account of ill health.

Ursula Wolcott, a daughter of Roger and a granddaughter of Martha Pitkin Wolcott, married Matthew Griswold of Lyme, who also became a Governor of Connecticut. The list of Ursula Wolcott's descendants makes a remarkable record, comprising "no less than twelve Governors, thirty-six high judges, and a galaxy of men eminent in other professions."

Martha Pitkin Wolcott Clark is buried in the old churchyard in South Windsor and on the weatherbeaten stone above her resting-place is the following inscription: 


\author{
Here lyeth; sleep- \\ ing in Jesus; ye Bo- \\ dy of $\mathrm{M}^{\mathrm{rs}}$ Mar- \\ tha Clark Alies \\ Wolcott Who \\ Died Oct. ye 13 \\ I7I9 Aged 80 Years
}

\title{
Ruth Wyllys
}

Mistress Ruth Wyllys, usually serene and smiling, wore a look of troubled contemplation one bright crisp day in October, I687. And was there not enough to bring serious thoughts and even frowns? Was she not a loyal daughter of the fair Colony of Connecticut-a Colony with the broadest and freest charter given to any people speaking the king's English?the charter secured by John Winthrop from Charles II., in I662? And now King James II. was trying to take away all the New England charters and was sending Andros, the meddlesome, tyrannical Governor of New York and Massachusetts, to take away the most cherished possession of the people of the Connecticut Valley. With their charter gone, the future looked dark indeed. But a few days before Ruth had heard Samuel Wyllys, her husband, 


\section{Txlomen of Colonial Times}

talking with George Wyllys, his father, former Governor of the Colony, and now its Treasurer. They knew and understood. And the charter itself was held for safe-keeping in their house, the Wyllys home for fifty years. And now the men were about to give it up without a protestshe could not understand it. Oh, if only she were a man! For the second time that morning she stole into her husband's room and glanced at the locked door of his oaken closet as if to assure herself that the precious document was safe. For had not her father-in-law said emphatically that as long as that instrument could be held on Connecticut soil, it was still their charter, even though its provisions be overridden or ignored for a time by force or violence? Then it was that there came over the face of Mistress Wyllys something that cleared away the frown but left a heightened colour in her cheeks and a brighter look in her eyes.

There was unwonted stir that day in the little town of Hartford. The streets were filled with people-country-folk in homespun and townspeople gravely serious. There were gathered members of the General Court and other 


\section{Dioneer Motbers of Almerica}

colony and town officials, farmers, and tradespeople. On the lane leading up to the meeting house, which would now be called the capitol, were drawn up troops, and at their head, pale and serious, sat Governor Robert Treat. Up the Boston and Hartford road there came the sound of martial music, and soon, riding along the route over which pastor Hooker had led his little flock half a century before, came a cavalcade in scarlet and gold with pompous Sir Edmund Andros, the whilom Governor of New England, at its head. All knew that this haughty, dark-faced man from Massachusetts was come to carry away the charter which Charles II. had given them twenty-five years before.

The spirited horse which bore Governor Andros was too restless to allow of his dismounting and he called to Lieutenant Wadsworth, who was in command of the little troop brought out to receive the Governor and his staff:

"Lieutenant, detail a man to hold my horse until my orderly comes for him."

Lieutenant Wadsworth knew the temper of his men, who remembered Major Andros at Saybrook some years before and had as little 


\section{vramen of Colonial Times}

respect for him as a man as they had liking for his errand to-day.

"Your Excellency," he said suavely, "I shall consider it an honour to hold the reins of so magnificent an animal myself."

"He is the best blood in New England," answered Andros, proudly, never feeling the slight of the remark.

"Yes," interpoșed Governor Treat, always conciliatory, as he extended his hand in greeting to his superior, "and you have the boldest blade and the best soldier in Connecticut to hold him."

After the formalities had been completed and the company dismissed, Andros and his suite, with Governor Treat and his staff, and the members of the General Court, passed into the council chamber to carry out the business upon which Sir Edmund had come. It was at this time that Lieutenant Wadsworth was approached by a black boy and told that he was wanted at the home of Samuel Wyllys, who lived with his father, Treasurer of the Colony, and formerly its Governor. At the Wyllys home he found his brother, John Wadsworth, and Nathaniel Stanley, officers of the General Court, in 


\section{Pioneer Mothers of America}

whispered conversation with Mistress Samuel Wyllys. They had come to fetch the charter, which Governor Treat had advised should be given up peacefully, in accordance with the orders of the King. Mistress Wyllys brought out the precious document: wrapped in its leather case, and passed it over to the officers of the Court, but it was noticed that the frowns had left her fair face though her cheeks still flamed and there was a light in her eyes as of one bent on some daring enterprise. The charter was first taken to the tavern of Moses Butler, adjoining the meeting house, until it should be called for. Lieutenant Wadsworth remained behind to learn why he had been summoned. Mistress Wyllys told him that it was best for him not to be seen in the meeting-house, and then she told him the reason, which will appear later.

An addition had been built to the old tavern, shading one of the windows of the council chamber. A stairway connected the window with Meeting House Lane, and a door, which could only be opened from the inside, led to the lane. The window was on hinges and was used as an exit by members or others when it was expedient to pass out of the council chamber 


\section{valomen of Colonial Times}

without going through it. At the suggestion of Nathaniel Stanley, Lieutenant Wadsworth passed through to the window, pushing the curtain aside far enough to see and opening it enough so that he could hear, yet remain unseen himself.

Sir Edmund Andros had ordered the room cleared of spectators and then had his commission read to the General Court. After this, Governor Treat called for the charter, which was brought in and laid before him. Speeches followed and debate, long and angry. The afternoon grew into evening and lights were brought in. Finally Sir Edmund, more pompous and disagreeable than ever, made a speech as tactless as it was insolent. He closed by saying:

"And while a number of you at this time yield reluctantly, it is well to remember that even Oliver Cromwell said that 'the ground of necessity for the justifying of men's actions is above all considerations of instituted law.",

Andrew Leete, a member whose father had been Governor of the colony of New Haven and afterward of Connecticut, arose to speak. His face was as one near death and he trembled as if with palsy. It was evident that he was on 


\section{Pioneer Motbers of America}

the verge of an epileptic fit, a physical weakness which was eventually to bring him to his grave. A strange silence fell on all present, but no one felt like interfering.

"You speak of Cromwell," he said, "you try to justify your acts and the acts of your patron by his words. You may have seen Cromwell but you could never have known him. My father and Oliver Cromwell were boys together in Huntingdonshire, and were intimates in early manhood. Half my father's life was devoted to the building up of Connecticut and maintaining its charter rights, as you no doubt remember, if your visit to Saybrook has not passed from your memory. On that day you retired discomfited, and by God's help you shall this time."

As Leete continued Andros's face grew black with passion, but the speaker went on: "That charter is in force at this hour. No judgment has been rendered against it. It was granted under the Great Seal of England and cannot be surrendered unless the surrender is given under the seal of this Colony. Remember the last words of Charles I., 'Measures obtained by force cannot endure.', 


\section{fulomen of Colonial Times}

As Andrew Leete finished speaking he fell forward on the table with arms outstretched, and in falling, upset both candelabra, leaving the room in total darkness. There was a hurried call for lights but before one could be brought, Nathaniel Stanley, who stood nearest the great oaken table upon which the charter rested, seized it and passed it to John Wadsworth, who in turn handed it through the half-open window to his brother, the Lieutenant. The latter, concealing it under his coat, rushed down the stairs, through the lane to Meeting House Alley, and thence to the river, and within a few minutes from the time the charter lay on the long table, in front of Governor Robert Treat and Sir Edmund Andros and the prostrate form of Andrew Leete, it was back again in the Wyllys home. Mistress Wyllys was expecting it, strange as it may seem. "But you cannot leave it here or in any other house," she said, "they will be the first places searched. But it must be hidden until Andros and his spies have gone back to Boston. Why not place it in the oak?"

Now to the good people of Hartford, the "oak" could only mean the great oak tree that stood on the Wyllys estate, not far from the house. 


\section{Dioneer MDotbers of America}

Again wrapping the precious package in his coat, Licutenant Wadsworth carried it to the foot of the oak, where Mistress Wyllys held it while he climbed up into the branches. Then she passed it up to him and he secreted it out of sight and out of reach in a hollow limb. Returning to the Wyllys house, Lieutenant Wadsworth was fitted out with a coat and cap belonging to Samuel Wyllys, and, supplied with a hastily prepared package of bread and boiled meat, he took to the woods to await Andros's departure for Boston.

And what of Andros? That truculent, loudvoiced Governor of all New England fussed and fumed and threatened, but what could he do? The charter could not be found. No blame could attach to the unfortunate Andrew Leete for having been afflicted with an epileptic fit in the meeting house and falling on the council table. Lieutenant Wadsworth was not in the building during the visit of Andros and was not even under suspicion. No person was known to have left the building and after two or three days, Andros, again discomfited in Connecticut, returned to Boston. For a year and a half, he ruled Connecticut as tyrannically 


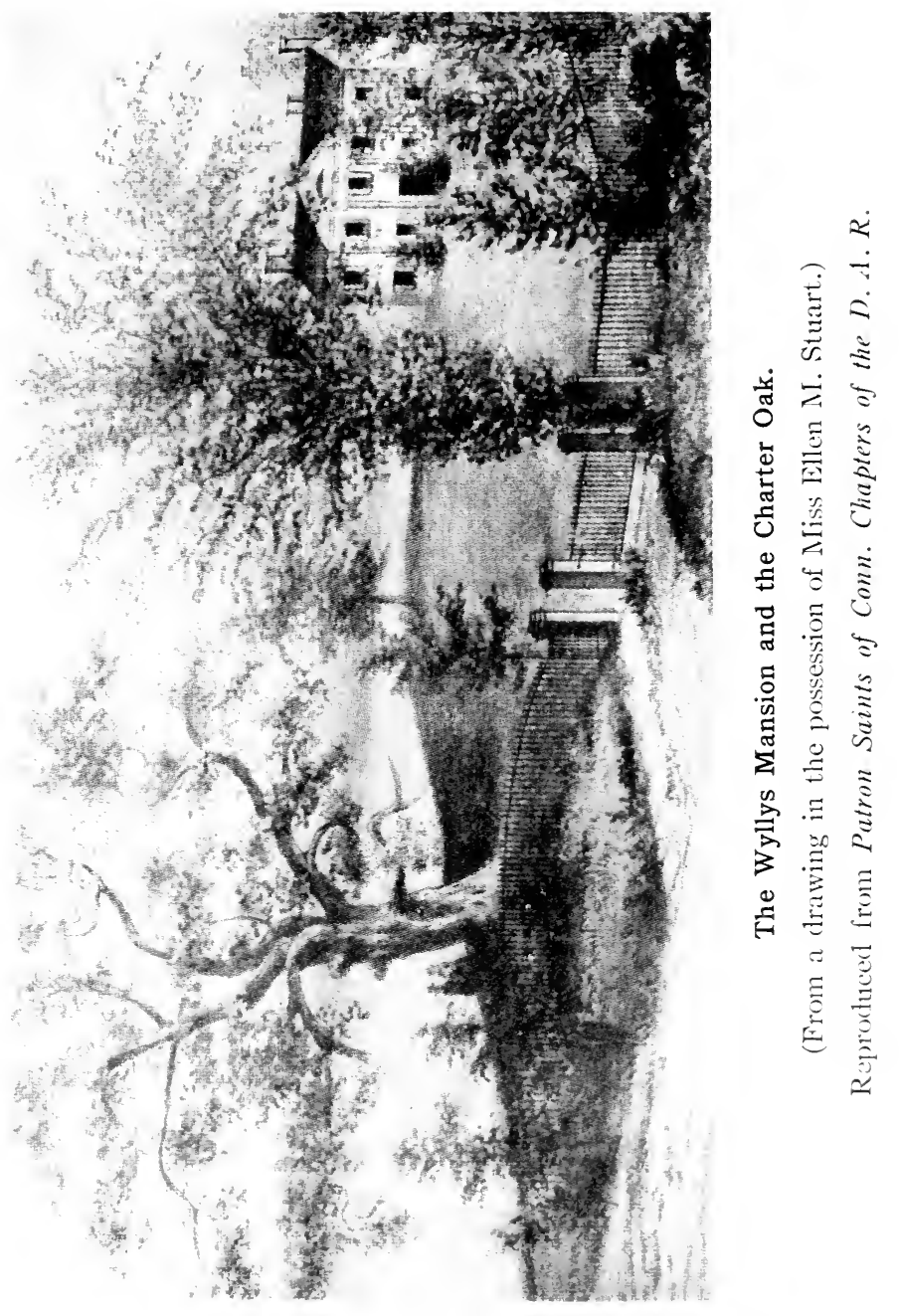





\section{ruomen of Colonial Times}

as he ruled Massachusetts, which had given up her charter peacefully. Then on the fall of James II. he was deposed, and immediately the charter reappeared almost as mysteriously as it had disappeared and was at once recognised as the law of the land and so continued for one hundred and twenty-nine years, while Massachusetts as a Colony never again regained her charter rights.

And Mistress Ruth Wyllys? Oh, she went on her serene and smiling way as usual, seeing her husband succeed his father as Treasurer of the Colony, an office that was held in the family for a period of ninety-seven years. Of the good woman herself we know but little beyond the church records. She had not even a tombstone, the Wyllyses not being given to such gauds. "No," said one of the family (of which generation we know not), "we need no graven stones. If the people of Connecticut cannot remember the Wyllyses without a monument our names will have to rot." We do know that she was the daughter of John Haynes, the first Governor of Connecticut, who had marched with Hooker through the wilderness from Massachusetts in 1636 , and built himself 


\section{Dioneer Mothers of America}

a house in Hartford, at what is now the corner of Arch and Front Streets. The Wyllys property was on the opposite bank of the Little River. Ruth Haynes had three brothers and two sisters. The brothers were graduated from Harvard College. That is about all that we know of her save that she "was comely and fair to look upon," and that she was married to Samuel Wyllys, the son of George Wyllys, the third Governor of the Colony and that she went to live in the old family mansion, in the grounds of which stood the Charter Oak. This mansion had been built by George Wyllys, who when he decided to leave his ancestral estate in Warwickshire, England, to cast his fortunes with the Puritans of Hartford, sent his steward, William Gibbon, with twenty men, framed timbers, and other materials to put up a house which remained in the family for five generations.

But Ruth Haynes Wyllys was not the only Ruth Wyllys in the family. Samuel Wyllys, the son of Governor George, was a member of the General Assembly for thirty-six years. His son, Hezekiah, was Secretary of the Colony in I 7 I 2 and was succeeded by his son George, who held the office for sixty-four years. This second 


\section{vulomen of Colonial Times}

George Wyllys had a sister Ruth, named after her grandmother, who married Colonel Thomas Belden. Their daughter was also named Ruth and it was this Ruth Belden who married her cousin Samuel Wyllys, and became Ruth Wyllys the third. Samuel Wyllys was, at the time of his marriage, a Colonel in the Continental army. He had been an officer of the State militia and served from the beginning of the Revolution with his regiment. In 1776 , his regiment re-enlisted and served under him in the New York campaign. He was commissioned Colonel of the new Third Connecticut Regiment and served with it for four years, mostly on duty on the Hudson Highlands or along the Connecticut border. During a portion of each year, his wife was with him. In I78I, Colonel Wyllys was retired by reason of regimental consolidation, but he was for a number of years a General in the State militia. He was Secretary of the commonwealth from I796 until I809, when he retired. Mrs. Wyllys, who died in I 807 , sleeps beside her husband in the ancient burial-ground of Hartford, where a Wyllys of later date has broken the ancient custom of his clan and erected a monument to the 
name, though there is no danger that Connecticut will forget the eminent services of the family.

Mrs. Wyllys, wife of the General, has been described by those nearer to her time as a "beautiful woman of a calm, sweet temperament, with dignified manners, and with an indescribable charm and loveliness of spirit that drew all hearts towards her." The Hartford chapter of the Daughters of the American Revolution have taken this Ruth Wyllys as their "patron saint," a fitting tribute to her high character and the brave and patriotic men who bore her family name.

There have been doubts cast upon the story of Lieutenant Wadsworth's seizing of the charter and hiding it in the Wyllys oak. The story has been accepted as true by the people of Hartford and of Connecticut, as well as the public generally, for more than two centuries, and it would seem as if this were rather a late day to cast doubts against its truth. Trumbull, the historian, accepted it, and there was nothing in the life of Captain Wadsworth to warrant our doubting his word. According to Wadsworth, the document secured by John Winthrop was 


\section{Trhomen of Colonial Times}

made out in duplicate and both copies were held for safe-keeping by the Secretary of the Colony. When, in March, I687, word was conveyed to Governor Treat and the General Court that Andros intended to take away the charter of Connecticut under quo warranto proceedings, the Secretary, John Allyn, and several others were in favour of giving up the charter without protest, but a majority of the General Court strongly opposed this and at the meeting held in June they demanded that the charter and its duplicate be brought into court and placed in the hands of the Governor. Upon this occasion, after the meeting had concluded without action further than protesting against any surrender of the charter, Governor Treat, Deputy Governor Bishop, and a few of their friends decided that it would be best to take one of the duplicate charters out of Hartford, and Andrew Leete was directed to take one of the copies to his home in Guilford and to secrete it, which he did. The other copy was given in keeping to a committee, consisting of Nathaniel Stanley, John Wadsworth, and Samuel Wyllys. This copy was taken to the home of Samuel Wyllys and placed in an iron chest, where the 


\section{Dioneer Mothers of Elmerica}

Wyllys family papers were kept, and there it remained until the following October when Andros came for it. This much of the history Captain Wadsworth says was told him afterwards by his brother John. For the history of the charter after Mistress Wyllys and young Wadsworth had secreted it in the oak we must take Wadsworth's own story: "I returned to Hartford and the following night removed the charter from the hollow oak and concealed it in a candle box which was fitted into the stone foundation of my house. It remained there unasked for, as but few knew what had become of it when it disappeared so mysteriously from the Council Chamber on All Hallow E'en, I687, until the May session of the General Court in I698, when I showed it to the Governor and Council and was instructed to retain it. The original was at that time in the hands of Samuel Wyllys, it having been brought back to Hartford by Andrew Leete, and was read to the freemen on May 9, I689, when for the peace and safety of these parts, the government was re-established as it was before Sir Edmund Andros took it. The duplicate charter lay in its box in my cellar 


\section{Vulomen of Colonial Times}

from May, I698, to May, I715, when most of those who had taken part in those stirring events had passed away. I deemed it advisable at that time to return it to the Governor and General Court, which after a conference passed the following resolution: 'Upon consideration of the faithful and good service of Captain Joseph Wadsworth of Hartford, especially in securing the duplicate charter of this colony in a very troublesome season when our constitution was struck at, and in safety keeping and preserving the same ever since to this day, the Assembly does, as a token of their grateful resentment of such his faithful and good service, grant him out of the colony treasury the sum of twenty shillings." "

\section{Letitia Penn}

The women of Philadelphia, from early Colonial days to the close of the Revolution, probably played as prominent a part in the making of history as did their sisters in other colonies, but at no time is there any one woman, or any group of women, standing out clear and distinct above others of the community. Nor 


\section{$35^{8}$ Dioneer Mothers of America}

is there any one woman or group of women around whom the story of the women of the time can be told, naturally, as was the case in New Amsterdam where the bustling black-eyed wife of Dominie Bogardus and the little coterie of housewives of which she was a part established a social group, which for more than a century dominated the society, business, and politics of that growing capital.

The reason is not hard to understand. Philadelphia was, almost from its beginning, the centre of the province in all its activities, social, educational, commercial, and political, not only attracting to itself much of the best blood and brains of the Province of Pennsylvania but drawing largely from the other colonies as well. It was settled more than sixty years after the Mayflower had landed the shivering Pilgrims on the cold coast of New England. New York was already a thrifty province with about 7000 people and the little children of Sir George Yeardley, Pastor Buck, and Ann Burras who had played about the palisaded walls of the fort at Jamestown were grey-haired men and women when, in I682, William Penn sailed up the Delaware on the good ship Welcome. 


\section{vulomen of Colonial Times}

The Colony was designed primarily as a refuge for victims of religious persecution, and especially for the Quakers, but it soon began to attract other religious refugees, many of whom came well provided with this world's goods. The first settlers of Philadelphia felt little of the isolation, the sickness, and starvation of the first Virginia and Massachusetts colonists, and none of the terrible hardships and suffering from Indian depredations that marked nearly every other colony, not only along the coast but in the march of the pioneers westward to the Mississippi. It was in fact a capital within a year or two from its founding. The little band of colonists who came over in I68I, on the John and Sarah, to begin building the city, found near and accommodating neighbours. There were already little Quaker settlements at Burlington, Salem, and one or two other points in West Jersey, and on the Pennsylvania side at what is now Allentown. A little group of German Protestants had started a settlement at what was later to be called Germantown, and farther south were a few scattered pioneers, in what were for many years the "Three Lower Counties" of Pennsylvania Province, now 


\section{Pioneer Motbers of America}

Delaware. These first settlers set to work with the materials they had brought with them and such other materials as they could find, to build for themselves and for those who were to come. To be sure, they lived in tents and "dugouts," while awaiting the erection of more imposing homes, and they were sometimes restricted in the matter of food supplies, but no serious or lasting suffering was experienced. In I682, William Penn came on the Welcome, bringing with him a number of the Society of Friends, and would have brought more but for the fact that the Factor which sailed at the same time as the Welcome and which bore other members was frozen in near the mouth of the Delaware and was unable to land her passengers until in the spring. That same year, there came twenty-three other vessels, each bearing colonists with their outfits of household furnishings, agricultural implements, seeds, live stock, and other goods. It was a busy time for the new city and the sounds of the ax, saw, and hammer were heard from dawn until darkness and even then there were many people who, until dwellings could be built, had to seek shelter in the dugout caves. But the wheels 


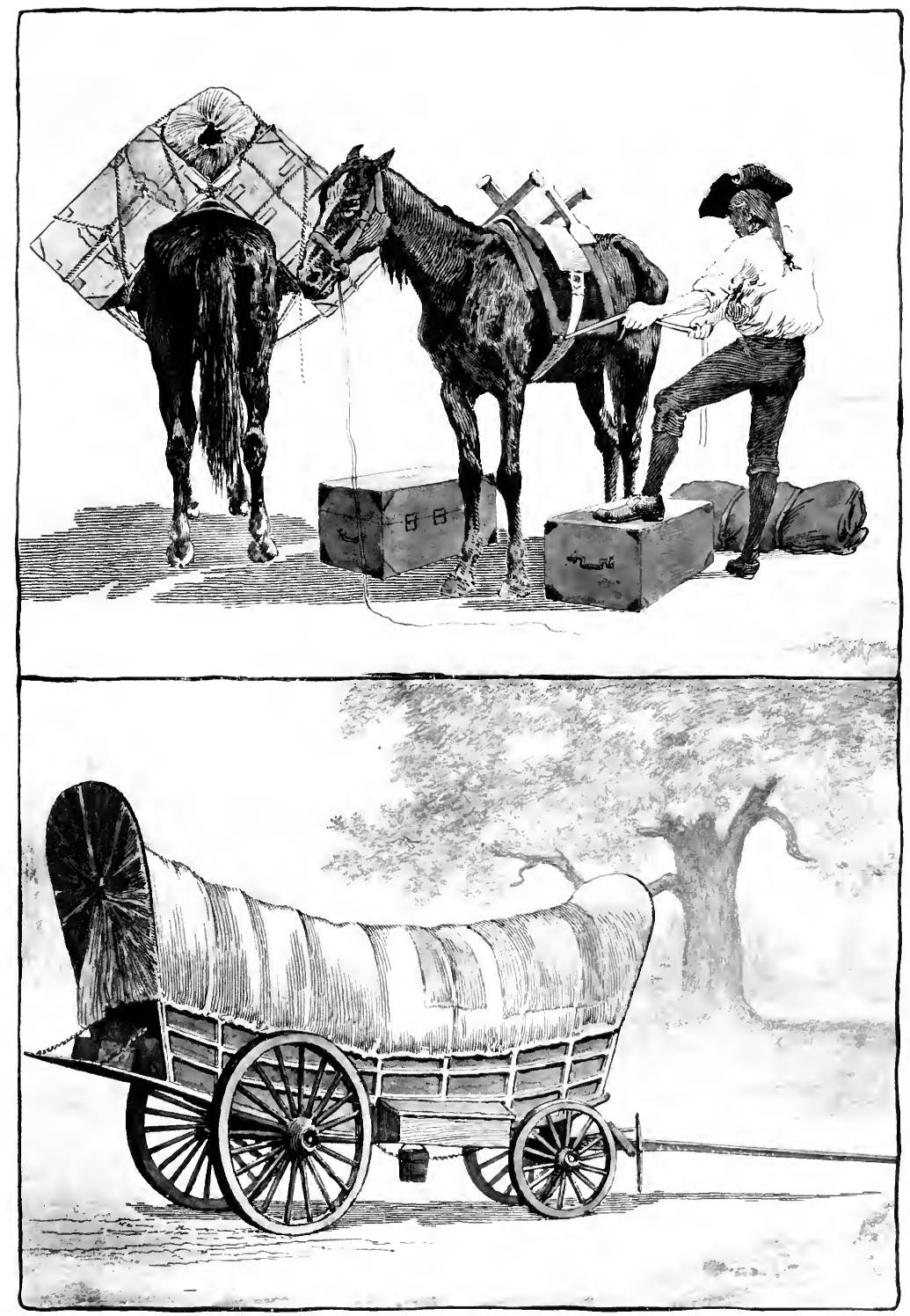

Pack-Horses and a Conestoga Waggon.

Redrawn by William J. Wilson. 



\section{rulomen of Colonial Times}

of progress had been set in motion and there was buying and selling and manufacturing, and people were coming in from all the surrounding settlements to trade and transact business. Not all the colonists who came on the twentythree vessels remained in Philadelphia. They scattered through the surrounding territory, peopling what now constitutes the counties of Philadelphia, Chester, Bucks, and Lancaster, but Philadelphia was the centre of all their activities. Nor could any one class be said to predominate, or stand out distinctly above another. There were Germans in and about Germantown, and along the lower Delaware the Swedes of South Jersey, who had lived and thrived in spite of all attempts of the Dutch to drive them out; the English settlers, mostly Quakers, "who came with Penn," the ScotchIrish who spread over what was to be Chester and Lancaster counties, Dutch from New York, and dissatisfied colonists from New England, $\therefore$ aryland, and Virginia, all soon intermingled so that before the Revolutionary War race lines were to a large extent lost. Thus it came about that the "first landers," as those who came over with the Penn migration were called, 


\section{Dioneer Mothers of America}

unlike the first settlers at Plymouth, or Massachusetts Bay, or Hartford, did not attain, or at least did not long retain, that dominating prominence in Colonial affairs that would have brought them distinction. We are wont to think of this early Philadelphia as the "Quaker city" and the province in its swaddling clothes as being almost entirely dominated by the sober-garbed and mildly-spoken followers of George Fox, but the fact seems to have been that almost from the founding of the province, the Scotch-Irish Presbyterians outnumbered the Quakers and really became the dominant people in the Colony, although there was a generous sprinkling of Germans, Dutch, and Swedes, who helped to make the province more cosmopolitan than any other. Without minimising in any manner the relative influence upon subsequent events of the original colonists, who came direct from England to Pennsylvania in 1682-3 and the decade that followed, it is a noteworthy fact that at a later date there came from all the American colonies men of marked ability to take conspicuous places in every line of notable endeavour. So the new metropolis prospered and grew "more in its 


\section{Trlomen of Colonial Times}

first five years than had New York in its first fifty."

The city and the lives of its public men have been well and ably described by scores of pens, but of the women not much appears except a few brief sketches in old family papers and here and there in the gossip of Watson's Annals.

William Penn's first wife, Gulielma Maria Springett, daughter of Sir William Springett, never saw America, but his second wife, Hannah Callowhill, whom he married in March, I696, came over with him on his second visit in 1699. She spent some months at the "slate roof house" on Second Street and lived afterwards at "Pennsbury," the Founder's famous mansion on the bank of the Delaware river in Bucks County. She was an excellent woman, sensible and loyal, and showed considerable business ability in her later days. Philadelphia was more interested in Penn's daughter by his first wife, who accompanied her father on the same visit. Letitia, or "Tishe," Penn, as she was generally known, seems to have been a light-hearted, winsome maiden, though the written records of her are but meagre. The sometimes garrulous Watson 


\section{Dioncer Smother of Elmerica}

tells of an incident illustrative of her girlishness, though she was then in her twentieth year:

"When she was at Thomas Evan's place in Gwinedd, seeing the men at threshing, she desired to try her hand at the use of the flail, which to her great surprise brought such a racket about her head and shoulders, that she was obliged to run into the house in tears, and expose her playful freak to her father."

"Tishe" became highly popular during the two years that she spent in the Colony, especially with the young people, and on her departure she took with her a certificate from the local Monthly Meeting of the Society of Friends that she had "behaved herself here very soberly and according to the good instructions which she hath received in the way of truth," etc., and that in so far as they knew she was under no engagement of marriage. But there were things that the staid and sober Friends did not know. In I702, we find James Logan, Penn's private secretary and closest friend, writing of Letitia's coming marriage, of which he had just heard:

"I cannot forebear informing thee of what has been too liberally discovered of her, and 


\section{relomen of Colonial Times}

among the rest by some that signed the certificate, viz: that she was under engagement of marriage, before she left this place to William Masters; the said signers, upon some unhappy information given them, lately expressed so great dissatisfaction at what they had done that it has been proposed to send over and contradict it or retract it."

This letter seems to have greatly incensed the Founder, who wrote to Logan, September 6, I702, informing him of the marriage of Letitia, three weeks earlier, and adding: "But S. Penington's, if not S. Harwood's striving for William Masters, against faith, truth and righteousness, will not be easily forgotten, though things came honourably off to his and the old enemy's confusion, his father's friends nobly testifying against the actions of both."

In any case Tishe was married, August 20, I702, to William Aubrey or Awbrey (for the Penns use both spellings), and it was hinted that the marriage pleased her father and stepmother more than it did her, which may have been the reason for the hurried departure of the Founder in the spring of $\mathrm{I} 702$, when it was generally supposed that he had come to Pennsylvania 


\section{Dioneer Motbers of Almerica}

to take up a permanent residence. William Penn, it will be remembered, suddenly abandoned his splendid country seat on the Delaware, and no one ever knew the reason. The matter died away and William Masters, some years later, married, but there were many people in Philadelphia, in the early years of the eighteenth century, who thoroughly believed that Ietitia Penn was in love with William Masters and that in going back to England and marrying Aubrey, she had rendered that obedience to her father which was made obligatory by her faith.

If this supposition was true, William Penn must have had many occasions to regret his interference, for Mr. Aubrey was anything but a satisfactory husband or son-in-law. "In all the subsequent history of the Penn family," says a plain-spoken local authority, "William Aubrey figures solely and entirely as an exacting and unpleasant person. His father-in-law's complaints of his demands for money on that side, and poor Logan's struggles to meet them on this, form for years a feature of the PennLogan letters."

William and Letitia Aubrey had no children and she died in 1746 , fifteen years after her 


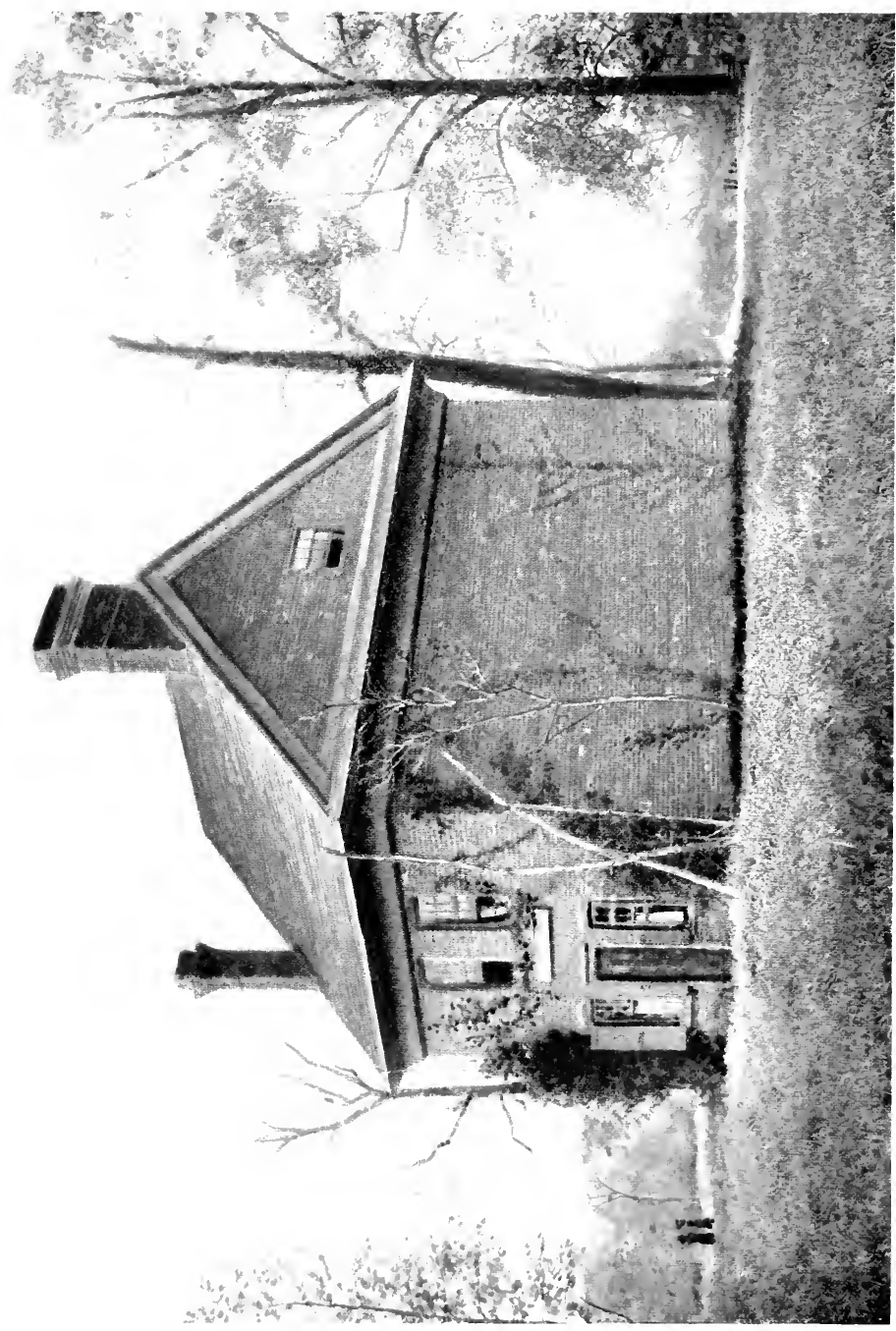

要 



\section{valomen of Colonial Times}

husband. There is another story, told in these old annals, of Quaker days and Quaker character that has in it more of the spirit of early Philadelphia than this crushed romance of little Tishe Penn. In the will of Deborah Morris, a prominent member of the Society of Friends, who died in the year 1800 , she gives the record of a heavy, old-fashioned silver salver which she leaves as a legacy to her nephew Thomas Morris.

"It was given to my dear parents," writes Deborah Morris in her will, "by my mother's aunt, Eliza Hard, a worthy good woman (she being the first orphan ever left in charge of George Fox's Society of Friends in England) whose sweet, innocent development used to give me high esteem and regard for the ancient people. She came from England with William Penn and other Friends. My Grandfather and wife came two years before her and settled in the Jersies; but when she heard her sister designed to Philadelphia, they removed thither also and first got settled in a cave on the bank of the river (Crooked British warf Ioo $\mathrm{ft}$. north of Chestnut St.) when my dear aunt [Hard] arrived; which she esteemed a divine providence thus to find 
her sister, whom she had not seen for some years, thus ready to receive her in the cave. They then dwelt together until they could build. . . . All that came wanted a dwelling and hastened to provide one. As they lovingly helped each other, the women set themselves to work they had not been used to before; for few of our first settlers were of the labouring class and help of that sort was scarce. My good Aunt [Hard] thought it expedient to help her husband at one end of the saw, and to fetch all such water to make mortar of, as they then had to build their chimney.

"At this time being overwearied therewith her husband desired her to forbear, saying: 'Thou, my dear had better think of dinner,' on which poor woman she walked away, weeping as she went, and reflected on herself for coming here to be exposed to such hardships, and then not knowing where to get a dinner, for their provisions was all spent, except small quantities of buscuit and cheese, of which she had not informed her husband; but she thought she would try and which of her friends had any to spare. Thus she walked toward her tent, (happy time when each one's treasure lay safe therein) but 


\section{Tulomen of Colonial Times}

was a little too desponding in her mind, for which she felt herself closely reproved; and as if quiried with,--'Didst thou not come for liberty of conscience, and hast thou not got it,also being provided far beyond thy expectations?' which so humbled, she on her knees begged forgiveness and preservation in future, and never repined afterwards.

"When she arose and was going to seek for other food than what she had, the cat came into the tent, and had caught a fine large rabbit, which she thankfully rec'd and dressed as an English hare. When her husband came in to dinner, being informed of the facts, they both wept with Reverential joy, and ate their meal which was thus seasonably provided for them in singleness of heart. And thus did our worthy ancestors witness the arm of Divine love extended for their support."

This tureen, skilfully engraved to show a cat in the act of springing on to a rabbit, was presented by the aged husband of "Aunt Hard" to his brother-in-law, who in turn left it to his wife's niece. Watson says that this tureen descended through Samuel Morris to Benjamin Morris, who had it melted up and made into a 


\section{Pioneer Mothers of Emerica}

more modern piece-an act of vandalism which we may be sure that he repented in later days.

Another Quaker maid whose love affairs, like those of poor "Tishe" Penn, shocked the sober sensibilities of her people was Sarah Eckley, an orphan heiress who eloped with and married Colonel Coxe, the knot being tied by Lord Cornbury's chaplain. A letter written at the time by Mistress Margaret Preston expresses the umbrage which she and her sect felt: "The news of Sarah Eckley's marriage is both sorrowful and surprising, with one Col. Coxe, a fine, flaunting gentleman, said to be worth a great deal of money-a great inducement, it is said, on her side. His sister Trust was supposed to have promoted the match. It took place in the absence of her uncle and aunt Hill, between two and three in the morning, on the Jersey side under a tree, by firelight. They have since proselyted her."

The first marriage in Philadelphia of which we have a record was that of Priscilla Allen and Thomas Smith, in I682. They came from the Isle of Wight and had "passed" one meeting. The first child born in the city was John Key, the little son of English parents, living for the 


\section{tromen of Colonial Times}

time being in a cave at "penypot landing," now the corner of Water and Vine streets. William Penn gave the little lad a lot, and he lived to become an honoured citizen, dying in I767. The first white child born in the province was Edward Grubb, who was born in a "dugout" in Delaware, in 168I. The Grubb family became one of distinction. To undertake even to enumerate the heads of the families from whom were to come the men and women destined to become prominent in the activities of the young metropolis, would be a far greater task than is contemplated in the scope of this volume. Enough has been told to show the polyglot nature of the population that was fast filling up the Proprietary of William Penn and was making it a fitting keystone for the arch that was to be fashioned of these straggling colonies along the Atlantic coast, well within another century.

\section{Hannah Dustin}

Nearly fourscore years before the Declaration of Independence, a deed of blood was wrought by a woman of Massachusetts, so daring in its conception, so ghastly in its execution, yet 


\section{Pioneer S1Dothers of Emerica}

fraught with so much of retributive justice, that her name has been held up to honour in many lands, and in her own and neighbouring States monuments and tablets keep ever green the memory of her heroism.

March 15, I697, was a cold, raw day in Haverhill, Mass. Snow still covered the ground, and from the east the wind blew chill and piercing. In the house of Thomas Dustin, in the western part of the sparsely peopled little settlement, all was peace and quiet. Mr. Dustin, with his horse and gun, had gone to his daily labour, some distance away. Mrs. Dustin, who has been described as a frail, sweet-faced, gentlevoiced woman of middle age, had given birth to a child but a few days before and was still confined to her bed. Mrs. Mary Neff, an elderly widow, who was acting as nurse, was engaged in household duties. Suddenly there was a commotion outside and through the window several Indians were seen trying to effect an entrance by the front door of the house.

"Hurry and call your father," commanded Mrs. Dustin. "All of you go, and run!" There were seven of the children besides the baby, which lay sleeping at its mother's breast. 


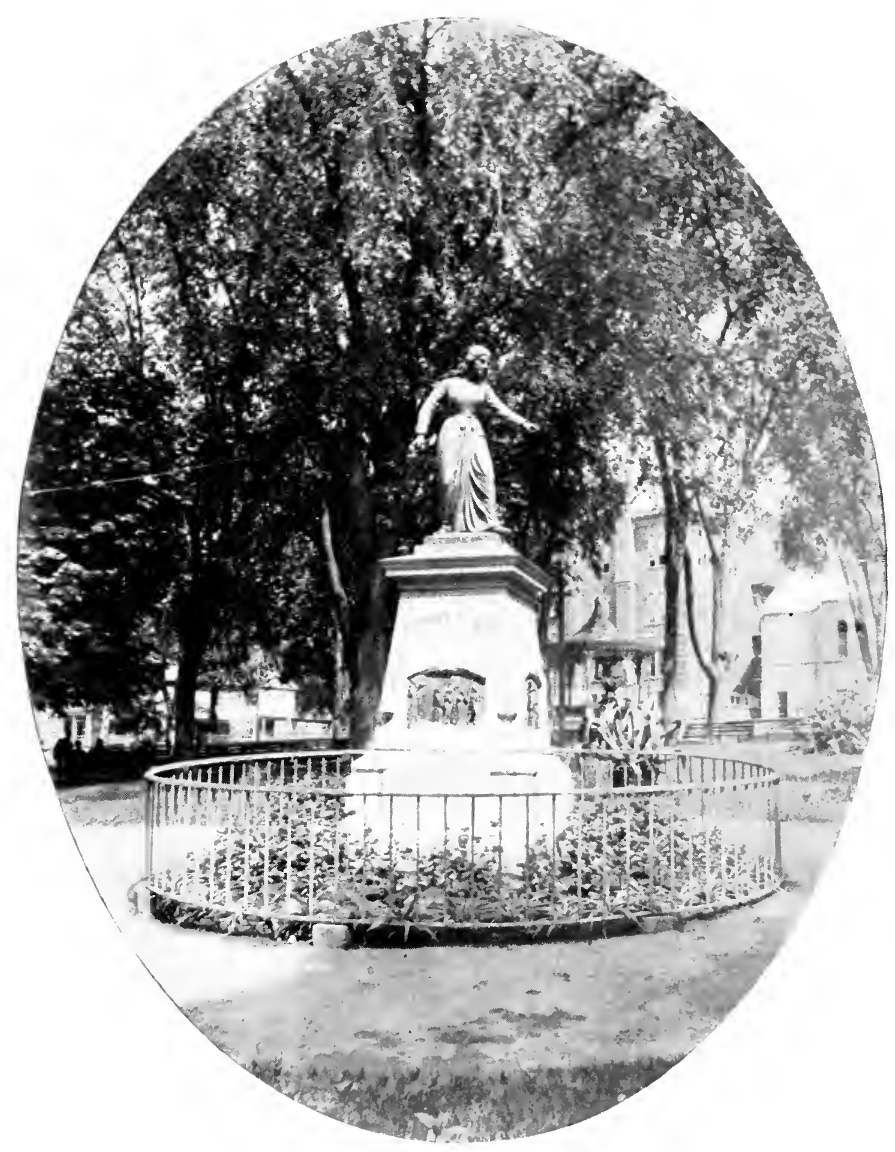

The Hannah Dustin Monument, Haverhill. 



\section{Oxlomen of Colonial Times}

The eldest, a girl of fifteen, snatched up her twoyear-old brother and out of the back door they ran.

When the Indians broke through the front door one of them seized the babe from its mother's arms, and, running back, dashed out the child's brains against an apple tree, in plain sight of the mother who sprang from her bed and tried to save it. The Indians hastily plundered the house, and then, compelling Mrs. Dustin and Mrs. Neff to accompany them, set fire to it and hurried away.

Thomas Dustin, when he received the alarm, started the children toward the garrison, about a mile distant, but not before several of the savages had sighted them and given chase. Bidding the children to hurry for their lives, Mr. Dustin rode between the Indians and his fleeing brood, and then dismounting and getting behind his horse, opened fire. The Indians returned this without effect. As soon as the children were inside the stockade, Mr. Dustin turned and rode toward his own home as fast as he could, but he was too late. The house was in flames and the Indians gone, and with them all traces of the mother and nurse. $\mathrm{He}$ 


\section{$380 \quad$ Pioneer Mother of America}

found the bloody remains of his infant son where the little body had been thrown, and supposed that the mother had been murdered and left in the burning building.

In the meantime Mrs. Dustin, who was but partially dressed and suffered terribly with the cold, and Mrs. Neff were being forced up the river, together with a number of other captives, making about twelve miles the first day. The retreat continued until the party had reached a small island in the Merrimac at the mouth of the Penacook River, about seventy-five miles from Haverhill and six miles above what is now the city of Concord.

At this point Mrs. Dustin and Mrs. Neff were left in the custody of a small party of Indians, while the major part of the band continued their retreat. In the party which held the two women were two men, three women, and seven children, most of them well grown. There was also another captive, an English boy named Samuel Leonardson, whom the Indians had carried away from Worcester some time before. Mrs. Dustin was told that when they arrived in an Indian town some distance farther up the river they were to be stripped and scourged 


\section{vulomen of Colonial Times}

and then made to run the gauntlet naked. Running the gauntlet was in itself a terrible ordeal to contemplate; but the prospect of this additional shame and suffering was too much for the two women to face and they made up their minds to escape or die making the attempt. So closely were they watched, however, that there was no opportunity until in the last days of April. The Indians were about ready to resume their journey to the north, and for two or three days their watchfulness was somewhat relaxed. Mrs. Dustin had several talks with the Leonardson boy, and found him as anxious to escape as she was. She told him to ask one of the Indians with whom he seemed to be on friendly terms how to strike with the hatchet so as to be sure of killing an enemy.

"Ugh! strike here," said the Indian, pointing to his temple, and followed by showing the boy how to take a scalp.

Early next morning about an hour before the break of day, Mrs. Dustin arose cautiously and found that all the Indians were sleeping. The smouldering embers gave but a dim and fitful light. Moving noiselessly, she secured three tomahawks and then aroused her two 
sleeping companions. She herself killed the Indian who had claimed her as his slave. There was not a groan or struggle as her hatchet sank into his brain, and none of the others were disturbed. This gave courage to Mrs. Neff and the boy, and they hurried on with their work of slaughter, sparing none, until ten Indians lay dead-all but one squaw, who, wounded, made her escape, carrying with her an Indian baby, which Mrs. Dustin had determined to spare. The two women and the boy hastily gathered what food they could find in the wigwams, and then hurried down to the canoes. Mrs. Dustin selected one of the largest and strongest and pushed it into the water. Then scuttling the others they climbed into the canoe and started down the Merrimac. Suddenly Mrs. Dustin stopped and said: "I am going to have their scalps." Pushing in to shore they returned and scalped the dead Indians, wrapping the scalps in a piece of linen which the Indians had brought from her own house. Mrs. Dustin also carried away the gun of the Indian who had claimed to be her master, as well as his tomahawk, knife, and scalplock.

The trip down the river was made without 


\section{tulomen of Colonial Times}

incident, and Mrs. Dustin found her husband and children, who had given her up as dead. After she had rested and recovered her strength, Mrs. Dustin, accompanied by her husband, Mrs. Neff, and the Leonardson boy, went to Boston, carrying with them the ten scalps, the gun and tomahawks. In Boston $\mathrm{Mr}$. Dustin presented a memorial to the General Assembly, asking recompense on account of the "just slaughter of so many barbarians," and of his own misfortune, "having lost his estate in the calamity."

The General Assembly awarded Mrs. Dustin $£_{25}$ (\$125), Mrs. Neff £I2 Io s. (\$62.50), and the same amount to Samuel Leonardson, "for their heroism."

Hannah Dustin was about forty years old at the time of her capture. She lived to a ripe old age, after having been the mother of thirteen children. She herself was one of a family of fifteen children.

The fame of Mrs. Dustin is commemorated in Haverhill in many ways. The site of the house in which she lived is called Mount Dustin, and is marked with a thirty-ton boulder, put up in 1908 , and a tablet. There is a Dustin Street, 


\section{$384 \quad$ Pioneer Mothers of Elmerica}

a Dustin Society, a Hannah Dustin High School, and in City Hall Square a Hannah Dustin monument, an imposing figure of heroic size, which was presented to the city by one of its most prominent citizens, in I878. There is another Hannah Dustin monument at Concord, N. H., and a memorial stone, about five feet in height, erected in 1902 by the D. A. R., which marks the spot near Nashua, N. H., where Mrs. Dustin and her companions spent the night on their return from captivity. Descendants of the Dustins are scattered all over the country, and their yearly reunion at Haverhill has grown to be an institution of the town.

Always there have been some to question the moral aspect of Mrs. Dustin's act, but it never seems to have troubled that good woman herself, nor her descendants. Cotton Mather, in his Magnalia, presents Mrs. Dustin's own views as: "Being where she had not her own life secured unto her, she thought she was not forbidden by the law to take away the lives of the murderers by whom her child had been butchered."

An aged descendant, who was one of the visitors at Haverhill at one of the reunions a 


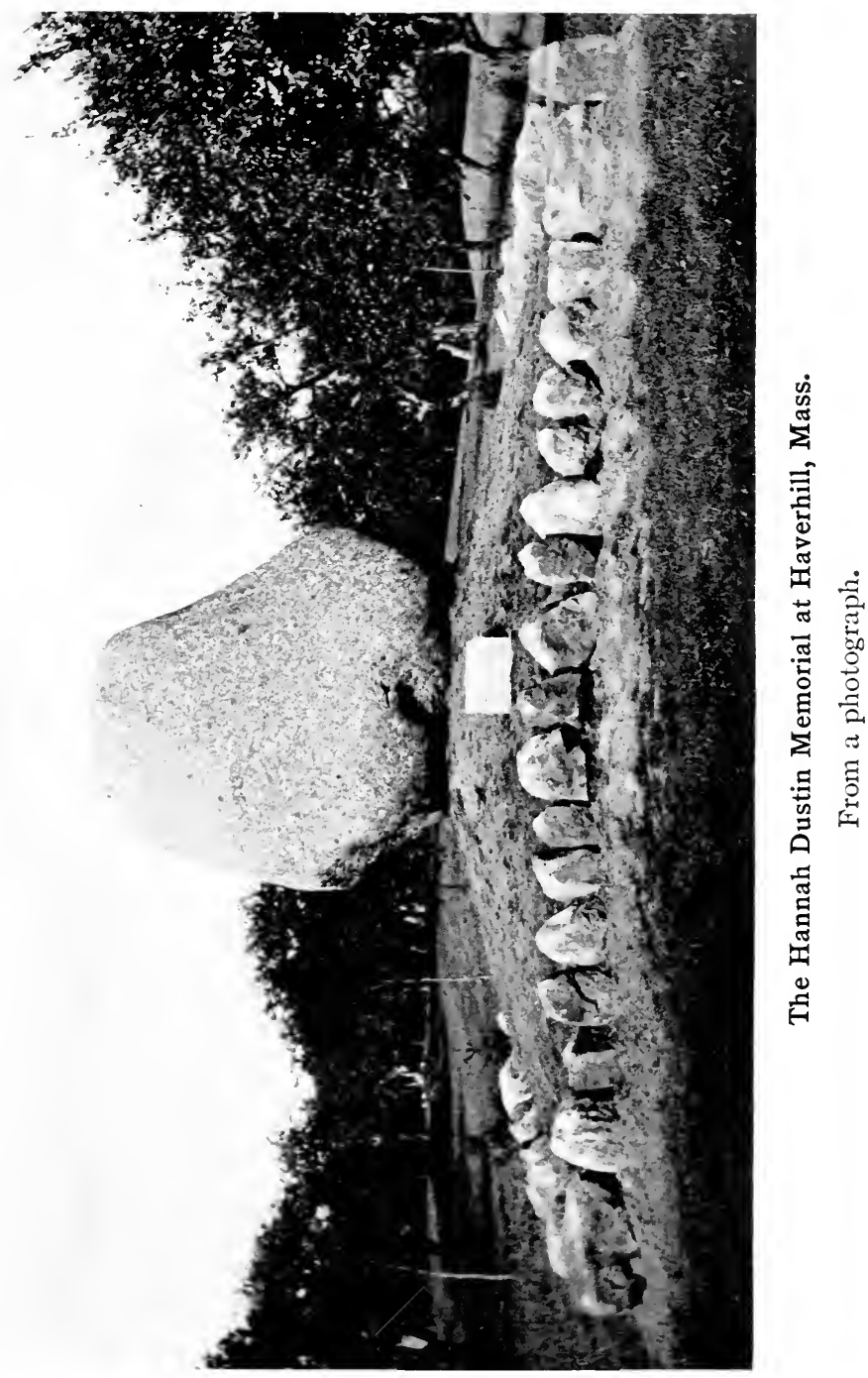





\section{Tuomen of Colonial Times}

few years ago, was asked whether in his judgment the scalping of the Indians was not a departure from the normal delicacy and sensibility so beautiful in womankind.

"Not a bit on't. Not a bit on 't," replied the old man with great spirit, "an' I glory in her spunk."

Many relics of the brave woman are preserved in the fireproof vaults of the Haverhill Historical Society, but one of the most interesting heirlooms in the family, a silver tankard, presented by Governor Nicholson of Maryland, is in possession of a descendant living in Newburyport.

\section{Betty Martin}

Among the historic relics on exhibition at the Chicago Exposition of 1893 , was an old and worn gold ring, set with amethysts, to which was attached the following inscription:

"This ring belonged to Betty Martin, the grandmother of Governor Paca of Maryland."

The ring, which rested in one of the glass cases directly under the dome of the Government building, was seen and the inscription read by thousands of visitors, a few of whom were interested by the quaintness of its old-fashioned 


\section{Dionecr Mothers of Emerica}

setting but most of whom gave it but indifferent attention, not remembering that Governor Paca of Maryland was one of the signers of the Declaration of Independence, and one of the first executives chosen by the people of his State. And, in her day and generation, Mistress Betty Martin, the "grandmother of Governor Paca," was a woman of note and one of the first of those "Southern Belles," so long the flower of America's most. beautiful and cultured womanhood. As a young woman, Betty Martin was sought after and toasted by scores of admirers in both England and her colonies, long anterior to the Revolution. Most persons have heard the old couplet:

"Pretty Betty Martin, tiptoe fine, Could n't get a husband to suit her mind."

If they have ever given the matter a thought, they have supposed that pretty Betty Martin was the figment of a whimsical imagination, like Little Miss Muffet, who sat on a tuffet, or that contrary young lady who is always being importuned by childish lips to tell how her garden grows. But Betty Martin was no myth, but a young woman of flesh and blood, of charming 


\section{tramen of Colonial Times}

personality and character, who not only found one husband to suit her mind but who was wooed and won by a second, and who lived to be a hundred years old and whose descendants to-day are among the most prominent and influential citizens, not only of their own State but of others.

In the year 1700 , according to the story told by one of her descendants, there was a party of Americans who had been spending some time in England and who took passage for home in the same vessel. In the party were William Martin, a wealthy Maryland planter, and his wife, who had crossed the seas to bring home their daughter, who had been abroad to finish her education, as was the custom with wealthy Southern families in Colonial days. With them travelled Richard Dallam, a young man of their- own colony and owner of "Cranberry," one of the finest estates on the Chesapeake, and who had also been abroad to complete his education by a year or two of travel on the Continent and in London. On the same vessel was another ardent admirer of the Maryland maid, William Smith, owner of the rich estate of "Blenheim," also along the shores of the 
Chesapeake. Smith was the son of the wealthy wife of the younger son of the Duke of Marlborough, by a former husband. The young man had been reared under the especial care of his stepfather, who, when he had completed his studies, had sent him to America, where he had purchased a large tract of land and devoted himself to farming. He was returning to "Blenheim" after a visit to his old home and had chanced to take passage on the same boat as Mistress Betty and her parents. It is needless to say that both young men were her devoted slaves, ready to answer her beck and call, but if she favoured one of them more than the other, or indeed either of them at all, she did not show it in her manner.

And why should she, she said. She was not seeking either of them or their company. Had she not left behind her in London a score or more of young men, rich and titled men too, who would have gladly doffed their very cloaks to save her sandals from the dampness of the ground? Both young men knew this and also they knew that not one of the gilded youth of London, who were sighing and writing sonnets to her eyebrows, or toasting her name, had 


\section{tramen of Colonial Times}

received anything more than she accorded them, and that was the privilege of fetching and carrying for her, waiting on her every whim, and then getting laughed at for his pains. $\mathrm{Oh}$, but it was a merry dance that she led her Maryland suitors, but never did she show that she favoured one more than the other.

At home in their beloved Maryland, after their long sea voyage was over, the fame of the maid after whom the lovelorn gallants of London were voicing their lackadaisical compliments spread and grew until half the eligible young men of the province were her suitors and all seemingly having just as good and no better chance than those she had left behind. If the affections of the capricious damsel were centred upon any one of her admirers, she never showed it. She had no time, she said, to consider such a thing as settling down. So she went on, playing her harpsichord, singing, dancing, flirting, riding with this one to-day and rowing with that one to-morrow. One after another of her admirers plucked up courage enough to propose, only to join the growing phalanx of the rejected. It was after some particularly desirable young man had 


\section{Dioneer SMothers of Emerica}

"loved and lost and rode away," that the anonymous couplet quoted came into being. Finally her friends and other people began to believe that she might be in earnest in her oft-repeated assertion that she never intended to marry. Then she suddenly surprised them again by saying that she was engaged to Richard Dallam, her friend and playmate since boyhood.

"I always intended to marry him," said Miss Betty, "but I did n't think it would do him any good to tell him so." And so they were wed and went to live at Cranberry, where Richard Dallam died while yet a young man. Two years later, his widow, still a remarkably handsome woman, was married to William Smith, who had been her admirer from the time of her homecoming, and went to live at Blenheim. After the death of William Smith, the estate of Blenheim, being entailed, went to his eldest son, and she returned to Cranberry, where she lived until her death in I778, a hundred years old and retaining traces of her great beauty and quick wit until the last.

The descendants of Betty Martin and Richard Dallam are numerous, not only in Maryland, but in Pennsylvania, North Carolina, and Vir- 
ginia. One of her grandsons William Paca, was an early Governor of Maryland, and also a signer of the Declaration of Independence. Another grandson was Governor Caswell of North Carolina, and the Dallams have furnished an almost unbroken line of eminent lawyers in Maryland. Among those of the present generation in Maryland, the seventh, are Judge Henry Clay Dallam and John Paca Dallam. A recent chapter of the Daughters of the American Revolution was founded in Texas, by daughters of Maryland antecedents, and named after Betty Martin.

\section{NOTES TO CHAPTER VII}

× Charnise afterwards visited Boston and complained to Governor Winthrop and the Council because of the damage he had suffered by reason of the aid the province had given his enemy, La Tour. It was explained to him that the matter was a private venture on the part of the Boston men engaged with La Tour with which the Governor had nothing to do. Then Governor Winthrop gave Charnise the Sedan chair which Captain Cromwell had brought home from one of his mysterious voyages and had insisted on presenting to the Governor, though that official had no use for it, and the Knight of Acadia departed in very good humour.

'Isaac Sears, leader of the "Sons of Liberty," led the mob that pulled down the statue after the Declaration of Independence had been read on Bowling Green, July 9, 1776. The statue was broken and cut up and while the greater part of the "remains" were carried aboard a schooner and transported to Connecticut, some of the parts were kept at home. The head is said to have been rescued by one Cox, an innkeeper at Kingsbridge, who turned 


\section{Pioncer Sibothers of America}

it over to the British authorities. The horse's tail and bridle are in possession of the New York Historical Society. According to "The Memorial of Henry Wolcott" in possession of the Connecticut Historical Association, certain ladies of Litchfield melted the legs, arms, and other parts of the leaden anatomy of George III. and moulded 42,088 bullets therefrom. 
"I HAVE often bad occasion to remark the fortitude with which Those disasters which break down the spirit of a man and prostrate bim in the dust, seem to call forth all the energies of the softer sex, and give such intrepidity and elevation to their characters, that at times it approaches to sublimity."-Irving. 



\section{Chapter VIII}

\section{Dome=making in tbe Watloerness}

Its perils and pleasures, hardships and compensations-Sarah Wells, the maid of Waywayanda, who went alone into the wilds of eastern New York to take up a land grant-Catheryna Rombout Brett, and the historic manor she founded at Fishkill on the Hudson-Mary Draper Ingles, the "first white bride west of the Alleghenies"; carried away by the Indians, she escaped, and travelled seven hundred miles through the wilderness to her home in Virginia-Jemima Howe's captivity, a tale of border warfare in northern New Hampshire-Sarah Knight, a Boston woman who visited New York in 1704, and her impressions-Mary Ball Washington, the mother of the Great Commander.

\section{IDWAY between the Shawangunk Mountains and the Hudson River, which mark the boundaries of} Orange County, N. Y., there stands a massive old stone farmhouse, slate tiled and ivy mantled, that has weathered the storms and sunshine of nearly two centuries. The building of this home in the wilderness marked the culmination of a romance of the pioneer days as tender and true as the storied loves of John Alden and Priscilla the Puritan. 


\section{Dioneer Mothers of America}

Had its chronicles been written, what tales that old house would tell of the early days, of the mutual trust and hope of the young builders that helped cement every stone in its place, of heavy burdens made light by affection, of forest perils, wild animals and wilder men, of the tears and laughter of little children-for from under the quaint gables and rough-hewn rafters of the old house have gone out the sons and daughters of six generations of the same blood-descendants of Sarah Wells Bull, "the Maid of Waywayanda"! She was so called because she went there alone, a girl in her teens, the first white woman to settle on the Waywayanda patent, a subdivision of that vast area granted in I63I to the Earl of Warwick, and described as "the country from the Narragansett, along shore forty leagues and westward to the Pacific Ocean."

The Waywayanda patent, which included about 160,000 acres in Orange and Sullivan counties, was purchased from the Minising Indians in $\mathrm{I} 702$ by Christopher Denne and a company of eleven other men, and the grant confirmed by Queen Anne the following year. The original grant was supposed to contain 


\section{Thome=making in the Vualdorness 399}

60,000 acres but subsequent surveys proved that there were about 160,000 Denne's allotted share was 2000 acres. He opened an office in New York and tried to sell the property to settlers but failed to make a sale. Finally, in the spring of I7I2, he decided to make entry himself and took a journey into the wilderness to select a site for a home. He found a location that pleased him on the west bank of the Otterkill, where now stands the village of Campbell Hall. The nearest settlement was at New Windsor, some eighteen or twenty miles away and a short distance below the present city of Newburgh. It was, at the time, but little more than a landing place for sloops and a lumber camp. Here Mr. Denne bought a sloop and hired a carpenter to build him a log house. $\mathrm{He}$ hired also two friendly Indians to accompany him home and to help him to move his family and effects into the woods.

Christopher Denne and his wife Elizabeth lived on Staten Island. They had no children, but with them was an orphan girl, Sarah Wells, about eighteen years old, whom they looked upon as their own daughter. She came of a good family in New Jersey and was a bright, vivacious 


\section{Dioneer Sotbers of America}

girl, well educated for the times and a notable house-wife. Arriving at his home, he found that his business seemed to demand his immediate personal attention and he decided that the plan would have to be given up for a time at least, though to do so meant considerable personal sacrifice as the original company had set apart 600 acres for the first of their number who should secure an actual settlement upon the Waywayanda patent ${ }^{1}$ and that bonus had never been taken. Also the site he had chosen for a home was upon this selfsame 600 acres. His home folks had become enthusiastic over the prospect of going to live in the wilderness and Mr. Denne's decision fell like a damp fog on their spirits. Suddenly Sarah spoke up: "Let me go. I'll start the home and have everything ready for you when you come."

"Do it and I'll give you a hundred acres adjoining my own farm," said her foster-father.

"I '1l go," said the girl, and although Mr. Denne pointed out the hardships and dangers of such a venture and Mistress Denne protested against it, Sarah knew the importance of having the entry made at once and would not give up the plan. In two or three days she was ready, 


\section{Dome=making in the waildernesg 401}

and, accompanied by her Indians and the carpenter, set sail on their little sloop on the afternoon of May 27, I7I2. The outfit she carried was described by her in later days, as follows:

"Two pack horses, with bells on, two milk cows with bells, two Irish Brahmas, two dogs, one spade, two pails, two beds with bedding, one small, and larger pot, one small and one large kettle, wooden trenchers and bowls, candlestick and candles, a frying-pan, small tin plates, coffee-pot and coffee, teapot and cannister, silver teaspoons, small china teacups, clothing in saddle bags, pillion saddle, knives and forks, some potatoes, medical cordials in vials, refined sugar in small pieces, brown sugar in rolls, small bag of flour, biscuit, a ham, some trinkets, ribbons and small knives for the Indians."

Twenty-four hours later they landed at New Windsor, and the next morning the party took to the woods. Mistress Sarah, the leader of the expedition, walked with the men, and afterward testified to their "most kindly and courteous treatment." The journey ended at nightfall, and the Indians soon had a wigwam set up for the young woman. Early next morning work was begun on the log house.

vol. $1-26$ 


\section{Pioneer Mothers of America}

After the departure of the pioneer maid, there was a very lonely house on Staten Island. Hardly had the little sloop passed out of sight into the mouth of the Hudson than Mistress Denne began imagining all sorts of dire disasters to her foster-daughter. Probably she told the good man that it was all his fault that the girl had gone away on any such crazy venture. Anyway it is on record that they passed a sleepless night and next day Mr. and Mrs. Denne locked the doors of their house, mounted their horses, and started across country, through the highlands of New Jersey, past the picturesque Ramapo Falls, until they reached their new home, just about the time it was finished, and the reunited family spent their first night in the log house by the Otterkill, in later days to be known as "the land o' Goshen."

Other families soon followed, and in a few years Mr. Denne had disposed of enough land to settlers to make him independent in fortune, and still left him a large landed proprietor. Among these settlers was Daniel Cromline, who very soon determined to build a tavern ${ }^{2}$ on the new highroad, which was being opened between the Hudson and Delaware rivers. 


\section{Dome=making in the ratloerness 403}

Stone was cheaper and more plentiful than other building material. He went to New York to find a stone mason, and there met William Bull, a young Englishman, just landed and in sore straits. He had held a contract to build a bridge near Dublin, but failed to complete it within the stipulated time. Unable to meet his obligations he escaped imprisonment for debt by sailing for America. When he arrived the captain insisted that his passage money was insufficient and that he must be sold into bondage to make up the deficit. Cromline advanced the money, finding that Bull was a stone mason, and took him back to his camp.

It was but natural that in time the young man should seek the nearest settlement, the home of Sarah Wells, and it was just as natural that the young people should become sweethearts. It was also, perhaps, just as natural that Mr. and Mrs. Denne should look askance at the young and penniless stranger until he proved his worth. He proved it. Settlers were coming fast into "the land o' Goshen," and the services of William Bull were in demand. He grew prosperous and thrifty, purchased 200 acres of land alongside the roo given Sarah Wells by 


\section{Dioneer Mothers of America}

her foster-father, and on March 25, i7 I8, they were married by Justice John Merritt, the second magistrate appointed by Queen Anne for the province.

This magistrate, who seems to have been a man of resources, smoothed out what had appeared to be a great difficulty. William Bull was a communicant of the Church of England, the canons of which require the promulgation of marriage banns upon three successive occasions to make valid the contract. Bull was a strict churchman, and not given to change from established custom. The magistrate could not make the extra journey from Albany or New York to pronounce the banns. How he helped them out of their perplexity is best told by Mistress Bull to her granddaughters many years afterward:

"After some deliberation, Justice Merritt concluded that three proclamations made the same day would be safe and valid under the circumstances. So the magistrate took his prayer-book in hand and went to the door in the front part of the house and there proclaimed the banns to the birds and the trees. Then he walked to the back door, looking out on the 


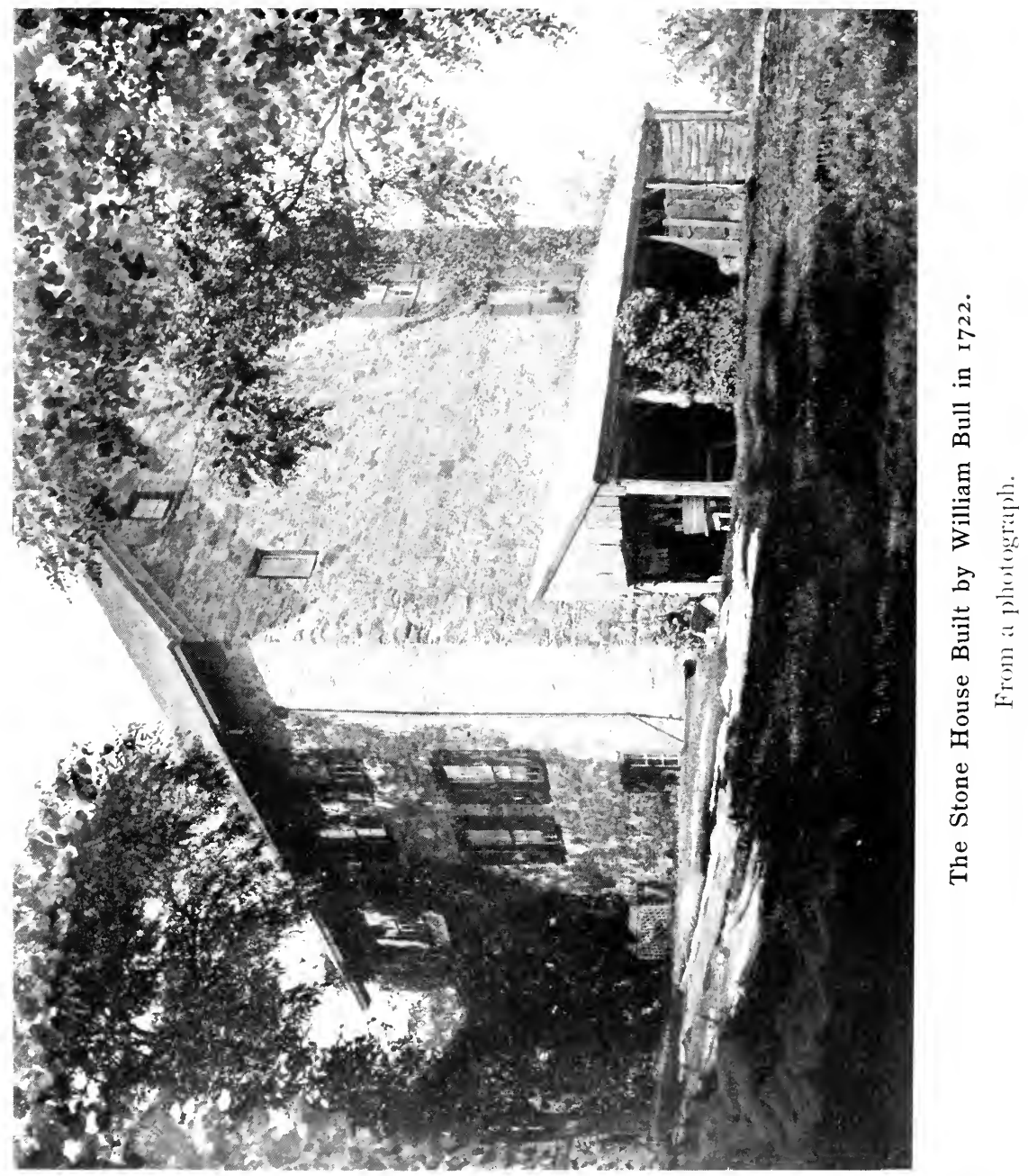





\section{Thome=making in the ratloernesg 407}

barnyard, and made his second proclamation to the cows and sheep. Then again he went to the front door where he pronounced the banns once more to the fields and wilderness at large: then as the cattle and trees, the birds and flowers seemed to give their consent, we were married."

Four years later, William Bull built the stone house. The young wife helped him so much in the building that he always insisted that they built it together. The structure was forty feet square, with walls three feet thick on every side. There was a cellar under the whole house, so that it was practically three stories and a half in height. Many years later, behind a blind wall in this same cellar several highly cherished colts were hidden to save them from British and Tory marauders, though the house itself was never seriously molested during Revolutionary times.

The life of Sarah Wells in her new home was not always one of monotony even if neighbours were scarce. From the advent of the Denne family, she had carried all their grist to the only mill within their reach, Madam Brett's mill at the mouth of the Fishkill on the eastern shore of the Hudson, across the river from New 


\section{Pioneer Mothers of Emerica}

Windsor and twenty miles away. She rode a horse, carrying a bag of grain. When she reached the river, she secured a boat and, lifting her bag of grain into it, rowed across, and waiting until the grain was ground, returned to New Windsor where she stayed all night and continued her journey next day. It is related that upon one occasion, on her way home, after having been delayed some hours, she was beset by wolves. She slid off her horse, whipped him to a run, and then climbed a tree. Next morning when the wolves were gone, she continued on her way and, about three miles farther on she found her horse cropping the herbage. The flour was still strapped to his back and was uninjured. After her marriage and removal into a home of her own, her husband relieved her of the milling, but as they had at first no horse, he was forced to make the journey on foot, carrying the grain to the mill and the flour back home and taking three days for the trip. On one occasion he did not return at the time he was expected and tying her baby to a bed-post, she started after him. She discovered him about ten miles from home almost exhausted from a sudden sickness. 


\section{Dome=making in the vatilderness 409}

Shouldering the flour and helping him along she brought all safely home, where she found her babe safe and still tethered to the bed-post.

William Bull died in 1755 at the age of sixtysix. His widow survived him until 1795, when she died at the age of 102. She sleeps by the side of her husband in the old burying ground in Hamptonburgh, on a little eminence overlooking the old stone house, where she lived to see 335 living children, grandchildren, and greatgrandchildren.

The old stone house is now the home of Ebenezer Bull of the sixth generation in direct descent from the builders and the founders of the family, William Bull and Sarah Wells. It is in an almost perfect state of preservation, and the interior is a veritable museum, where may be seen the old hall clock imported by William Bull from England, the spinning wheels and looms used by Sarah Wells Bull and her daughters, old-time cooking utensils and dishes, and many other rarely interesting relics of the early days, and including a photograph of the wedding dress worn by Sarah Wells, and in which a number of the daughters of five generations have been married. The dress itself 


\section{Io Pioneer Motbers of Âmerica}

is in possession of another branch of the family in New Jersey, and is one of their most,cherished belongings.

The Bull stone house stands on the old road between Newburgh and the county seat at Goshen, from which it is distant about five miles. Goshen itself was built on the old Waywayanda patent. It is estimated that there are more than I5,000 living descendants of Sarah Wells Bull and her husband, and their annual reunion at Campbell Hall and the old homestead is one of the most interesting yearly events in Orange County.

\section{Madam Catheryna Brett}

It was just a century to the year after Hendrik Hudson sailed up the great river that bears his name, in 1609, with the thought that he might in this way find the northwest passage, that Catheryna Brett, the first white woman to establish a home in the Hudson Highlands, came with her husband to build a manor house on the Rombout Precinct. Another century was to see Robert Fulton, the inventor, trying out his strange little craft on these same waters, 


\section{Dome=making in the ounildernesg 4 I I}

steaming up the current, past the great house built a hundred years before, by Catheryna Brett, and now occupied by her descendants, of the third generation. Another century finds the river covered with craft gaily decked in honour of the anniversary of the discoverer and the inventor, and still the stately old mansion is standing, peopled with other generations of the same blood that flowed through the veins of Catheryna Brett. This would be no uncommon thing in older countries where centuries are as decades here, in the matter of family trees and genealogies, but notable with us and our newer civilisation and more restless people. More notable, however, is the manner in which fate has, in this old mansion, linked some of the great names of the dim past with the living present.

Catheryna Brett was the daughter of Francis Rombout, a Flemish Huguenot who came to New Amsterdam in 1654 and began life as a trader. He prospered, built a stone house on De Heere Street (Broadway), surrounded it with an orchard and garden, became an elder in the Dutch church, Dutch schepen and English alderman, and finally Mayor. $\mathrm{He}$ had also 


\section{I Dioneer IDotbers of Almerica}

served as Lieutenant under Captain Beekman, in the bloodless war that drove the Swedish flag off the American continent, and was one of the six public-spirited citizens who maintained a well from which the people of the little city drew their water. Also he had married three wives, the last of whom was Helena Teller Van Ball, a widow, and daughter of William Teller, the rich Albany fur dealer, who founded Schenectady. Helena Teller's first husband was Cornelis Bogardus, a son of Annetje Jans and Dominie Bogardus. Catheryna Rombout was the only child of Mayor Rombout and Helena Teller who lived to come to maturity. She was born in 1687 , and four years later her father died, leaving his daughter "his land in the Wappins." This meant his share of a tract of 85,000 acres, extending from the Fishkill Mountains nearly to the present line of Poughkeepsie and half-way back to the Connecticut line. The other two owners were the heirs of Gulyne VerPlank and Stephen Van Courtlandt who with Mayor Rombout had bought the land from the Indians, the Rombout patent with its manorial rights having been issued by Governor Thomas Dongan, as one of his first official acts. 


\section{Thome=making in the walloerness $4 \mathrm{I} 3$}

Catheryna Rombout was married at the age of sixteen to young Roger Brett, a Lieutenant in the British navy who had come to New York with Lord Cornbury, when that erratic nobleman was sent over by his cousin, Queen Anne, to be inflicted upon the Dutch colony. We do not know whether or not Catheryna was one of the young ladies whom Lady Cornbury gathered into her household as "maids of honour," ostensibly, but really as maid servants, but she must have been of the best social set in the province, wealthy and well educated, as well born. Four years later Madam Rombout died and the Mayor's De Heere Street property, which her mother had held in trust, was turned over to Mistress Brett. There was inborn in the young matron a love of the woods and the hardihood of the pioneer, and that is probably the reason why the young people decided to take up their residence in the "land in the Wappins." Anyway, we find them, in I707, securing a division of the Rombout Precinct, through the courts, by which they secured a third lying on the river and Wappinger's Creek. Next we find them mortgaging the De Heere Street property for 240 pounds, current 


\section{Dioneer SDothers of America}

money, wherewith to build on their forest estate.

The ancient homestead, which they erected, was a roomy structure for primitive days, "with foundations of native stone well laid; the beams of immense hand hewn timbers and the scalloped red cedar shingles, hand cut and secured by hand wrought nails are graceful in simplicity and lasting in quality," as has been proven. There have been undoubtedly many changes and some additions and improvements in the old house during the two hundred years, but practically it stands as it was built, in I709.

Very soon after Roger Brett and his wife had landed from the sloop that had carried them and their household goods up the Hudson, Madam Brett, who seems to have been blessed with a great deal of business foresight, selected the site for a grist-mill which was built in 1708 , which almost from the first became a prosperous venture. A mill house was also built which was for a time occupied by the Bretts. Madam Brett's Mill was for years about the best known point on the Hudson River between Albany and Tarrytown. It was the only mill for many miles and to the new settlers who soon began 


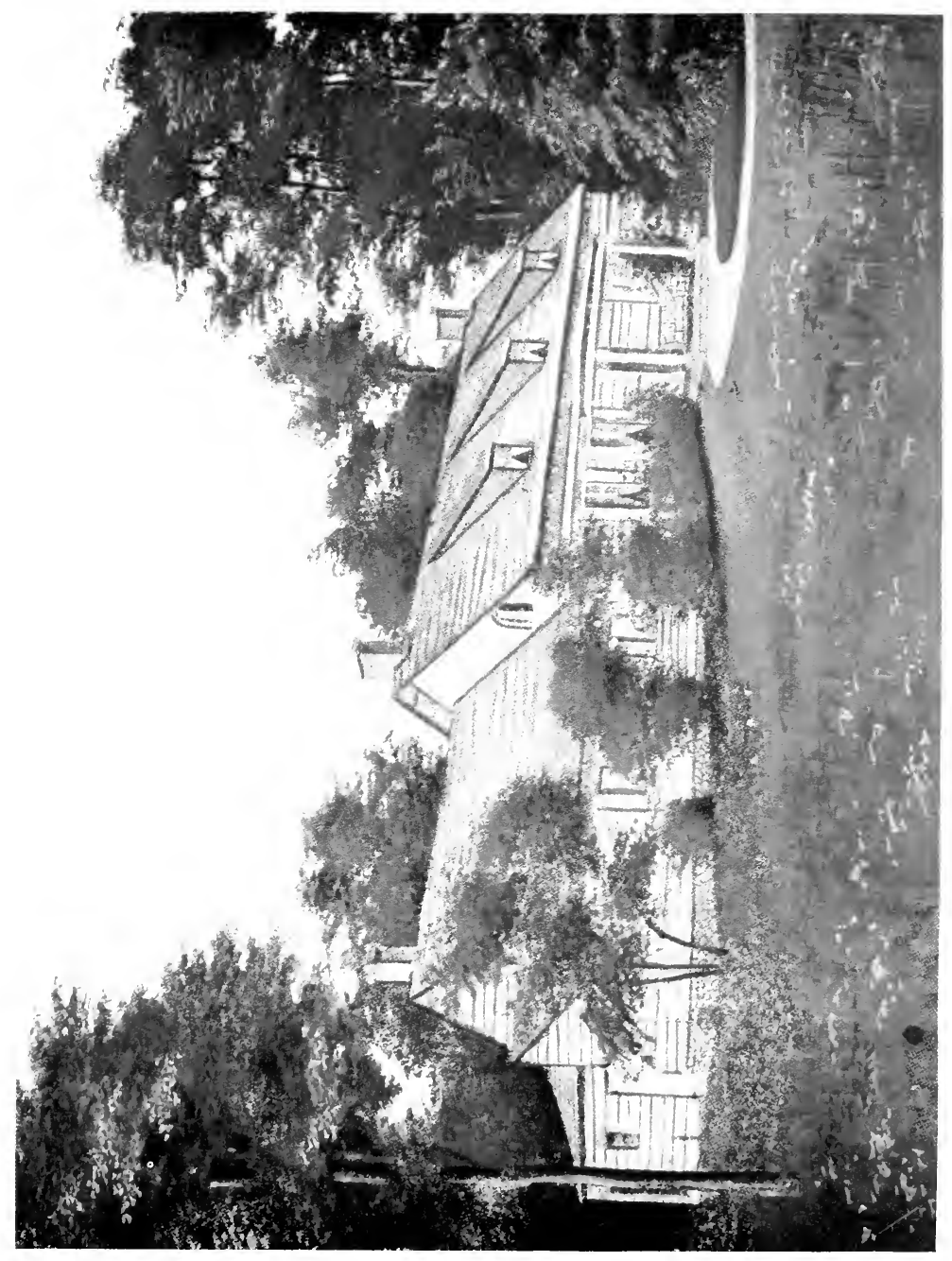

$r$ 



\section{Thome=making in the ruilderness 417}

to pour into Orange County, and those who followed the Bretts up from Manhattan into Dutchess County, it was their only relief from the mortar and pestle of the Indians. More than half a century ago, an aged citizen of Orange County told how in his youth the settler or his wife strapped a bag of corn on the back of a horse and rode to New Windsor, where the horse was tied and the settler, securing an Indian canoe, rowed the grain across to the Madam Brett's mill, had it ground, and returned as he came.

Madam Brett was left a widow in 1726 , when her husband was drowned from his sloop on his return from New York. She had three sons, Francis, Robert, and Rivery; the latter, the youngest, was so named because he was born on board the little vessel upon which she was coming up the river from a visit to New York. He died at the age of seventeen. With her two eldest boys the widow greatly extended their farming operations, cleared more land, erected farm buildings, always prospering and always remaining on the best of terms with her tenants.

In 1737 , Francis Brett, her eldest son, married voL. $1-27$ 


\section{Dioneer SiDotberg of Emerica}

Margaret Van Wyck, daughter of General Abraham Van Wyck, who had been reared in the homestead in Fishkill Village, made famous in Cooper's novel, The Spy During these years we hear of Madam Brett "galloping daily over her broad acres, superintending her many affairs," and of her own grain industry having grown so large that she joined her neighbours in the erection of a storehouse and freighting depot. This Franklin Storehouse became a commercial centre for the county farmers. There were twenty-two shareholders or partners and it cost Madam Brett fifty-seven pounds, current money, for her share, but inasmuch as she sold the site on which the building was located, furnished a number of the workmen who built it, and loaned some of the other shareholders the money with which to pay their part in the undertaking, it is not likely that she was much the loser.

When, in I $7 \mathrm{IO}$, the forty-odd Palatine families came to Newburgh, across the river, they had built a church, and Roger Brett, a communicant of the Church of England, and his wife, a member of the Dutch Church in Manhattan, used to row across Newburgh Bay to attend church 


\section{Dome=making in the raildernesg 419}

under the Lutheran pastor In I73I, the people of Fishkill built a church of their own and Madam Brett gave the land upon which it was erected, and then sold them another parcel. This Dutch church was the first religious edifice in the Rombout Precinct. In a collection of Local Tales and Sketches published in Poughkeepsie, I874, we read in an account of the wedding of the Rev. Mr. Van Nest, the joint pastor of the church of Poughkeepsie and Fishkill:

"As the hour of twelve drew near, the excitement became intense and what added more to the enthusiasm was the appearance of Madam Brett, in her coach drawn by four horses, coming down Main street [Poughkeepsie] with two negroes on the front seat and one on the rear of the coach, whose business it was to open the door."

These are but brief glances into the life of a woman who by her dignified enterprise and industry had made of her unproductive forest heritage a rich and productive domain. Many families of her own people had followed her into the wilderness, and to all who needed succour she was ever ready to hold out a helping hand. 
The Indians, then fast becoming a vagabond race, were her warmest admirers and the recipients of her bounty, all her life. When she died, in 1764 , generally respected and mourned by the people of the entire Highland section, she was buried in the shadow of the church she had helped to build and endow, and when it was subsequently enlarged, the pulpit was built directly over her grave.

The next occupant of the homestead erected by Catheryna Brett and her sailor husband was her granddaughter, Hannah Brett, who a few months before Madam Brett's death was married to Henry Schenck, son of Judge Abraham Schenck of Long Island, who was one of the most prominent men of the province, and thereby added another chapter to the tale of three centuries. It seems, according to a tradition in the Schenck family, as related by Alice Crary Sutcliffe in her delightful monograph, The Homestead of a Colonial Dame, that the President of the Dutch East India Company, in 1609, was Admiral van Schenck of the Dutch navy. "Believing in the importance of Henry Hudson's quest for the Northwest Passage to India, the Admiral allowed his son Sir Roelof 


\section{Dome=making in the traildernesg $42 \mathrm{I}$}

Schenck, as supercargo, to embark with Henry Hudson and accompany the famous expedition of the Half-Moon. Young Schenck participated in the thrilling adventures which marked the discovery of our river, and accompanied Hudson upon the return voyage. They landed at Dartmouth, England, and so aroused the jealousy of the English East India Company, by the recital of their discovery, that the members influenced Hudson to re-enter their employ. But the supercargo, Roelof Schenck, carried to Holland the news of the voyagealthough it is averred that the Half-Moon was detained from its return to Holland until I6I0, when Hudson sailed thence in an English ship upon his final voyage.

"The glowing account of the newly discovered land as related by Sir Roelof to his father, Admiral van Schenck, enabled him to inspire seventeen business men of Amsterdam to form a trading company for traffic in furs with the American Indians. An expedition numbering sixty natives of Holland, led by Roelof Schenck, sailed in 1610 for America and established a trading post on Boswyck (Bushwick) Creek and at Flockland (Flatland), Long Island. 


\section{Dioneer SiDothers of Êmerica}

Mr. George E. Schenck, who committed this information in a letter to a relative further alleges 'that in 1852 the ruins of the old mill established by these settlers were visible and that in the old burying-ground, some two hundred and fifty descendants of Roelof Schenck were interred. Moreover, among the signatures of persons who, in 1678 , in response to Governor Nicoll's edict, took an oath of allegiance to the crown of England, in Buswick and Flatland, appear the names 'Roeloffe Martin Schenck, Jr., 47 years; Jan Martins Schenck, 37 years; Jacob Schenck, 23 years,'- possibly sons of the sturdy Roelof, supercargo of the Half-Moon. Johannes Schenck, who emigrated from Holland in 1683 , is recorded in Flatbush as Town Clerk, in 1694 , and in 1712 , he purchased the mill property at Bushwick, doubtless the same building set up by his enterprising kinsman, Sir Roelof. It was Johannes' great-grandson, Henry, born in I745, who, coming from his ancestral home in Bushwick, wooed and won fair Hannah Brett, in the homestead of her grandmother."

It was this same Henry Schenck who was appointed Major in Colonel Swartwout's regiment and rendered gallant service during the Revolu- 


\section{Thome=making in the valilderness 423}

tion. It is a proud tradition of the old Fishkill homestead, that General Washington, crossing the river from his headquarters at Newburgh, accepted the hospitality of Major and Mistress Schenck and that later both La Fayette and Baron Steuben were guests beneath the same roof. After the war, Major Schenck served in the Assembly and died in I799.

The next in line of descent to occupy the homestead was Alice, the second daughter of Hannah Brett and Henry Schenck. She has been described as a very handsome girl. She was married in I790 to Isaac De Peyster Teller, the fifth in descent from William Teller, the old Albany fur trader, who founded Schenectady, and who was the grandfather of Madam Catheryna Brett. Abraham De Peyster had, in I743, bought the mill property from Madam Brett, and in $177^{\circ}$, bequeathed it to his nephews, Oliver and Isaac DePeyster Teller. So Alice came to live in the mill house, where her great-grandmother had set up housekeeping eighty years before. This building is still standing and is now known as the Newlin house. She continued to live in the mill house until in $\mathbf{I} 800$, when Isaac De Peyster Teller bought from his mother- 


\section{Dioneer Motbers of Emerica}

in-law the old homestead, though Mistress Schenck continued to reside there with her daughter until her death. To Isaac De Peyster Teller and his wife Alice, were born seven children, five of whom were girls. The oldest son married and went elsewhere, but Isaac and the daughters remained at home, where they lived their lives out, with the exception of the daughter Margaret. Isaac Teller served a term in Congress and was well known as a gentleman farmer and a kindly, scholarly man, generally loved and respected in the community in which he lived. The family donated the ground for an Episcopal church which was erected, and the first clergyman to officiate within its walls was Rev. Robert Boyd Van Kleeck, of Newburgh. He fell in love with Margaret Teller, one of his parishioners, and they were married in the old homestead. One by one, the remaining members of the family were carried to their long homes, and, finally the property came to Mrs. Van Kleeck, and after a long and busy life in the ministry, she and her husband were permitted to spend their declining years in the home of her childhood. To-day, the eldest grandson of Robert Fulton, the inventor, Robert Fulton 


\section{Thome=making in the tailderness 425}

Crary, DD., lives in the old mansion, which through the inheritance of several generations has come to be the property of his wife, a direct descendant of that fine old Colonial Dame, Catheryna Rombout Brett.

\section{Mary Draper Ingles}

Among the heroic pioneer women, without whose courage and fortitude the wilds of this continent could never have been subdued, the story of none stands out in bolder relief than that of Mary Draper Ingles, the first white woman to see the Ohio River.

One of the first settlements west of the Alleghenies was that of Draper's Meadows on the New River Fork of the Great Kanawha, now the heart of West Virginia. Into this smiling stretch of fertile meadow, deep hidden in the mountain recesses, half a dozen Virginia families penetrated in $\mathrm{I} 747$. Three years later, two of these families were united by the marriage of Mollie Draper to William Ingles, son of a near neighbour. Mollie Draper was eighteen years old and a splendid specimen of frontier girlhood. She was the belle of the little settlement, strong and sturdy, lithe and active as 


\section{Dioneer Mothers of America}

a young panther, full of life and vivacity, and fair to look upon. It was said of her that "she could stand by the side of her horse and leap into the saddle unaided, ride anything on hoofs, and shoot like a hunter, as well as being highly skilled in all housewifely accomplishments." Several years went by in which the little colony was unmolested and passed peacefully along, 'knowing but little of what was going on in the outside world. Then came an awakening, as terrible as it was unexpected. War had broken out and the western Indians, won to the side of the French, were incited to attack the English-speaking settlers, wherever the curling smoke from a cabin gave warning of their encroachment.

On Sunday, July 8, I755, the day before Braddock's defeat on the Monongahela, a band of marauding Shawnees came creeping up the Kanawha and New rivers. The settlement at Draper's Meadows was caught entirely unprepared and nearly every member of the little community either killed, wounded, or captured. Among the latter were Mrs. William Ingles, and her two little sons, Thomas and George, and her sister-in-law, Mrs. John Draper, whose 


\section{Dome=making in the railderness 427}

arm was shattered by a bullet which killed the babe in her arms as she was escaping from her cabin. William Ingles, the husband, was some distance away at the time, and hurrying back, was intercepted by the Indians and barely escaped with his life. John Draper was also away from home. The Indians at once started down the New River with their captives and such plunder as they could carry.

The condition of Mollie Ingles was most pitiful. Torn from husband and home with her two little sons, one two years old and the other but four, and surrounded by savages, she was facing the most critical period of her life. That night, under a canopy of leaves and aided only by her sister-in-law, Betty Draper, one of whose arms was tightly bandaged, the miracle was wrought. Next morning, carrying the tiny girl stranger at her breast, she was forced to continue the retreat to the Ohio, though her captors relented enough to allow her to ride one of the horses they had captured. Though the Indians treated most of their captives with great brutality, Mrs. Ingles, because of her tact in simulating cheerfulness and contentment, and her ability to make herself useful, was shown 


\section{Pioneer Mothers of America}

more leniency and consideration than the others. She was permitted to ride and to carry her children, as well as to bandage and care for her wounded sister-in-law.

The Indians stopped at the salt springs above the mouth of Campbell Creek, on the north side of the Kanawha, where they spent several days making salt and killing game, which was very plentiful about the springs. It is an interesting coincidence that Mrs. Ingles's great-grandson, John P. Hale, the West Virginia historian, was for many years a salt manufacturer "within a few hundred yards," as he writes, "of the spot where she helped the Indians make salt in I755." From the salt springs, the party hurried on down the Kanawha and as Mrs. Ingles was on horseback and therefore had a higher view-point than the others, she was the first American white woman to see the great river, "the River of Many White Caps," as the Indians called it. Down the Ohio the party proceeded to the mouth of the Scioto, where on the northern shore the Shawnese village was situated.

Here the Indians rested and celebrated their victory with an orgy of eating and drinking. 


\section{Dome=making in the ralloerness 429}

All the prisoners, excepting Mrs. Ingles: were compelled to run the gantlet, after which came a division of the spoils, including the prisoners. Mrs. Ingles because of her deftness in needlework and general usefulness was kept in the Shawnese town but her two little boys were taken north to Detroit. "Betty Draper,"2 as she was generally known, was carried to the present town of Chillicothe by an old Indian who adopted her, and the other captives were parcelled out, here and there. Mrs. Ingles was in a few days compelled to go with a party down the river to the salt springs at Big Bone Lick, in Kentucky, about fifty miles below the mouth of the Scioto and three miles back from the Ohio.

All this time the hope of escape was ever present in her mind. She believed that her husband had escaped death, though the Indians told her that he was wounded. She knew that her little boys had been carried to the north, but where they were or how they fared, she did not know. She had little doubt that they were alive and probably kindly treated, but they were being raised as Indians, and that to a frontier mother was almost as bad as death 


\section{Dioneer Mothers of Almerica}

itself. To get to her husband, nurse him back to health, and set in motion some plan to recover their boys was now the one object and aim of her life.

In the party at Big Bone Lick was another captive, an elderly Dutch woman, captured in Pennsylvania and brought in some days later than Mrs. Ingles. She, too, was eager to escape, and the two planned and plotted for days. What to do with the baby was the one question that could not be settled. The mother would not leave it behind, and, the old woman said that the journey could not be made if they took the infant with them. There were many things that Mary Ingles had to take into consideration. She knew that she was an attractive woman, doubly so now that she had shown her usefulness. She knew that it was only a question of time before she would be compelled to take a husband from the tribe. She must escape. If she took the infant with her, it increased manyfold the chances of their being discovered, and recapture under such circumstances meant death or degradation worse than death. She knew that they could carry no food with them, nor had 


\section{Dome=making in the ratilderness $43 \mathrm{I}$}

they any firearms or other means to procure food. The Dutch woman said that it was doubtful if the mother in her enfeebled condition could stand the hardships of such a trip and that the babe must starve. Finally, Mrs. Ingles decided to leave the babe and trust to its being raised an Indian, rather than to give up the hope of rejoining her husband and regaining her boys.

Late one afternoon, the two women slipped away from the salt makers at Big Bone Lick and made their way down to the Ohio, which they followed up-stream until a late hour. Each carried a blanket, tomahawk, and huntingknife and such food as they had been able to secure. Apparently there was no pursuit, and their long weary journey of seven hundred miles, as the Indians reckoned it, was begun. They ate leaves, berries, roots-anything they could find in the forest or along the river bank that would stop the never-ending craving-and grew pinched and wan with hunger. Their clothing was soon in tatters and they bound the strips about their tired and torn feet with thongs of leatherwood bark. Opposite the mouth of the Scioto River, they came to a patch of corn on the site of a deserted village. The ears were 


\section{Dioneer Mothers of Emerica}

over ripe, but to the women it was as manna from heaven. Across the river in the Shawnese town the Indians could be plainly seen, but, desperate with hunger, they ate to repletion, and then lay down and went to sleep, trusting to the tall stalks to hide them from view. At daybreak they were awakened by the ding-dong of a cow-bell. Springing up in alarm they discovered that it was worn by an old Indian pony, turned out to shift for itself. The Dutch woman detached the bell and fastened it to her own person, saying that she was going to carry it home with her. With as much of the corn as they could carry, and leading the pony, they started on, keeping back in the underbrush until the Indian village across the river was lost to sight. After that they alternated in riding until they reached the Big Sandy, which was too wide and too deep to either swim or ford, and so they had to ascend it to find a crossing. They found one-a vast pile of driftwood, reaching from bank to bank. Both women passed over in safety, but the old pony went through and they were too weak to save him.

This blow, following upon the hunger and 


\section{Thome=making in the valloerness 433}

hardships, seemed to have unsettled the mind of the older woman. She turned upon MIrs. Ingles and upbraided her wildly for having "lured her to her death in the woods." These paroxysms of insane rage increased in frequency and violence as they ascended the Kanawha, Mrs. Ingles only saving herself from injury by the mad woman at times, by her superior agility. Finally, while on the most desperate part of the journey through the great canyon of the New River, there came a life and death struggle. Here on the narrow margin between the water's edge and the precipitous bank which rises almost perpendicularly at some points to 1500 feet, these gaunt and haggard women fought and, but for the failing strength of the elder, Mrs. Ingles might have died by the tomahawk, almost within sight of her own home. Mrs. Ingles dared travel no more with her and, crossing the river on a floating $\log$, went on alone. The last mile she dragged her weary feet was for her about the hardest. Reaching Anvil Rock, which towers 280 feet above the water, she tried to wade around it, but could not, because of the depth and the strength of the current. Nerved by the realisation that behind that pile 


\section{Dioneer Mothers of Emerica}

of stone lay her old home, she climbed and dragged her weakened frame up and over the precipice and down on the other side into a cornfield owned by a neighbour. She called feebly and became unconscious. She was heard and was cared for and a few hours later was with her husband, who had just returned from a trip to the Cherokee Indians in search of her.

One of Mrs. Ingles's first conscious acts was to send back aid to the Dutch woman, who was met on the way. She had come upon a hunter's empty cabin in which she had found food and a pair of old leather riding breeches, and grazing outside the cabin an old worn-out horse. She had donned the breeches, tied her bell about the neck of the horse, and when discovered was threading the mountain path, astride her steed, singing and holloaing at the top of her voice.

The old Dutch woman, for history gives her no other name, soon recovered and started for her home in Pennsylvania, but was never heard from afterward. The Ingleses recovered their eldest boy, but the younger had died soon after leaving the mother. Of the baby they never found a trace, though father and mother searched far and wide. Mrs. Ingles was blessed afterward. 


\section{Thome=making in the ruildernesg}

with several other children, and her descendants are many and widely scattered all over the South and West, and in the Ohio Valley. One of them, a great-grandson, has written the story of her life.

\section{Jemima Howe}

In the latter part of July, I 755, the same year and month that saw Mary Draper Ingles carried away from her home in the Virginia mountains by the Shawnees, a similar tragedy was being enacted at the little frontier fort at Hinsdale, New Hampshire. Three men, Caleb Howe, Hilkiah Grout, and Benjamin Gaffield, who were at work in the fields near the fort, were shot down and scalped by the Indians, and their three wives and Howe's six children carried away. The captives were taken to Crown Point at the southern end of Lake Champlain, where the party divided. Mrs. Howe and some of the other prisoners were held here for some time, while the remainder of the party, which included Mrs. Howe's youngest daughter, were taken to Montreal, where the Indians expected to sell their prisoners to the French. In this, they were disappointed and 


\section{Pioneer Mothers of America}

all the prisoners were brought back to the lake, with the exception of Mrs. Howe's little daughter, who had been given to the French Governor, the Marquis de Vaudreuil.

Immediately the whole party was started in canoes for St. John's. At night the storm that had been gathering all day broke, and in the darkness and confusion, the canoe which held Mrs. Howe and her captors became separated from the others. All night the Indians struggled with the storm, and a little before daybreak, succeeded in making the land. Here on the barren shore of Lake Champlain, drenched and cold and almost distracted with grief over the death of her husband, and ignorant of the whereabouts of her other children, she strove to quiet the babe at her breast and gain some rest, to take up the search for her children. Another day's journey brought the party to St. John's and soon afterward to the tribe at St. Francis. Here the Indians held a council at which the prisoners were divided, Mrs. Howe and her babe being given over to an old squaw, whom she was bidden to call "mother."

As soon as she had become acquainted with her surroundings, Mrs. Howe began trying to 


\section{Thome=making in the tuildernesg 437}

persuade the squaw to take her to Montreal, and sell her and her babe to the French. She feared facing the coming winter in a wigwam with a babe at her breast and besides the chance of being ransomed and returned to her home was better from among the French than among the Indians. Finally, they set out. The journey was a long and hard one and Mrs. Howe and her babe came near perishing from the cold, the lips of the little one at times being so benumbed that it could not take its proper nourishment. In Montreal they were disappointed. No one wanted a woman with an infant child. After a time the squaw and her prisoner returned to St. Francis, and soon afterward the squaw took sick and died of smallpox.

The Indians were getting ready to go on their annual hunting expedition, and Mrs. Howe was in demand in helping to make these preparations. Because the babe interfered with her work, it was taken away from her and carried to Missiskow, on the northern end of Lake Champlain. After a few days she was given opportunity to visit it and she did, finding it emaciated, dirty, and almost starving. For three nights she was allowed to cherish and 


\section{$43^{8}$ Dionecr Mothers of America}

nurse the little thing, but in the daytime it was taken from her and confined in a nearby wigwam, where she could hear its cries without being allowed to go near it.

The third day the Indians removed her several miles up the lake, where she was set at some work. That night occurred the memorable seismic disturbance known in local history as "the great earthquake." The Indians were badly frightened and fled in every direction as shock followed shock for several hours. Two days afterward, the Indians came back and one of them told her that two of her children were dead. Half crazed with grief and privations, she wandered away from camp and after several hours came to a wigwam and there she found one of the children who she had been told was dead. The child was well and well cared for. A few days later, she learned, from a friendly Indian that her other child was alive and living across the lake. She got permission to be absent for a day, and went to him. She found him thin, hungry, and unkempt, but about as well cared for as the children of the family where he lived. She had a small cake of Indian bread, which she had brought 


\section{Mome=making in the venilderness 439}

with her, but she did not dare run the chance of offending the family by giving it to her son alone, but was forced to divide it among the group. But one day was allowed for this visit and, at the parting, both mother and child were alike heartbroken.

The following summer Mrs. Howe passed at St. John's. She lived with the daughter and son-in-law of the old squaw who had been her "mother" when she came into the tribe. Early in the season the man set out with a war party against the English settlements. On their return they held an orgy to celebrate their deeds. Knowing that he was always ugly tempered after a debauch, his squaw warned Mrs. Howe and together they hid themselves until he should have recovered. Mrs. Howe chanced to be the first to return to the wigwam, and the master, surly and ill-natured because of the absence of his wife, hurried Mrs. Howe to St. John's where he sold her to a Frenchman, named Saccapee, for a small sum. As the Indian's anger cooled he realised that he had made a poor bargain and threatened to murder Mrs. Howe and set fire to the house. Saccapee hid Mrs. Howe and kept watch until the Indian 


\section{Pioneer SDothers of America}

became sober and returned to his tribe. For a time Mrs. Howe's life was somewhat pleasanter than it had been for months. Her new master and mistress were liberal and indulgent, so much so indeed that she was often able to befriend other prisoners, who were from time to time brought to St. John's.

Yet here in this humane family she was to meet another trial that to a woman of her character was harder to bear than the persecutions of the Indians. Both Monsieur Saccapee and his son, who was an officer in the French army, became enamoured of Mrs. Howe, who was still a young woman and more than ordinarily attractive. Her position was a delicate one. Her own safety and that of her children depended upon her maintaining friendly relations with this family. In her distress she turned to Colonel Peter Schuyler of Albany, who was a prisoner being held for exchange, and who was regarded as a man of great prominence.

Colonel Schuyler immediately made known her situation to Governor de Vaudreuil, who met it by ordering young Saccapee back to the army and enjoining upon his father "just and honourable treatment of the lady." Nor did 


\section{Thome=making in the ruilderness $44 \mathrm{I}$}

his kindness stop there, for on hearing that Mrs. Howe's eldest daughter was in danger of being married to an Indian of St. Francis, he rescued her and placed her in a convent with her youngest sister, the one that had been presented to him by the Indians. Both girls were educated at the Governor's expense as his own children. Nor did Colonel Schuyler's kindness end with his first favour. He advanced twenty-seven hundred livres and interested other gentlemen so that Mrs. Howe was enabled to ransom herself and her four little sons. Then Colonel Schuyler placed her and her children among a party of ransomed and exchanged prisoners who were returning to the colonies, commending her to the care of Major Israel Putnam. The balance of the story is better told in Livingston's Life of Putnam:

"In November, Putnam started homeward with the family. The younger Saccapee is said to have followed them a part of the way, much to the alarm of Mrs. Howe. She was, however, gallantly defended, for Putnam informed the young officer that he should 'protect that lady at the risk of his life.' Of the same guardian on that long journey from Canada 'through an 


\section{Dioneer Mothers of America}

inhospitable wilderness,' we have this picture in Humphrey's quaint style:

" "There were a thousand good offices, which the helplessness of her [Mrs. Howe's] condition demanded, and which the gentleness of his nature delighted to perform. He assisted in leading the little ones, and carrying them over swampy grounds and running water with which their course was frequently intersected. He mingled his own mess with that of the widow and the fatherless and assisted them in supplying and preparing their provisions. Upon arriving within the settlements, they experienced reciprocal regrets at separation and were only consoled by the expectation of soon mingling in the embraces of their former acquaintances and dearest connections." "

After the treaty of peace at Paris in 1763 , Mrs. Howe went to Canada and brought home the younger daughter, who left the convent with reluctance. The elder daughter went to France with Governor de Vaudreuil's family, and was later married to a Frenchman named Louis.

\section{Sarah Kemble Knight}

Sarah Kemble was born in Boston, April 19, 


\section{Dome=making in the railderness 443}

I666. She was the daughter of Captain Thomas Kemble and Elizabeth his wife, the gravestones of whom may still be seen in the old Copp's Hill burying-ground. Captain Kemble was a well-to-do Boston merchant, the American agent of a London firm, and seems to have been held in high repute by his Puritan neighbours, which, considering the strictness of their rules of conduct, would indicate that he led a very circumspect life. But the records show that, at one time, he was severely reprimanded and placed in the stocks for two hours for "lewd and unseemly behaviour." Investigation shows that the worthy Captain had been away on a three years' voyage and that upon his return his good wife had met him on the doorstep and that his "lewd and unseemly behaviour" consisted of kissing her publicly, thereby violating the statutes, made and provided, and greatly shocking his good Puritan neighbours. But, further than this, there is no official record against him, and it may be assumed that his one fall from grace was at last condoned by his neighbours and that he was reinstated in their good opinion.

Sarah Kemble was reared in Boston, as were 


\section{Ploneer Mothers of Ëmerica}

her numerous brothers and sisters, and considering her sex and the times, was very well educated, probably receiving her religious training under the great Dr. Increase Mather. Of her early life there is very little record, but we know that she eventually married a $\mathrm{Mr}$. Richard Knight, whose chief bid for fame seems to have been the fact that he was Sarah Kemble's husband. Aside from this fact little is known of him, save that he was the captain of a London ship.

In I704 Madam Knight came into some property, which necessitated her making the trip from Boston to New York. She elected to make the journey by land and on horseback, and her journal describing her adventures furnishes an interesting picture of Colonial times. The journal begins:

"Monday Octb'r. $y^{\mathrm{e}}$ second, I704.-About three o'clock, afternoon, I begun my Journey from Boston to New: Haven: being about two Hundred Mile. . . being ignorant of the way, $\mathrm{Mad}^{\mathrm{m}}$ Billings, seing no persuasions of her good spouses or hers could prevail with me to Lodg. there that night, Very kindly went wyth me to $\mathrm{y}^{\mathrm{e}}$ Tavern, where I hoped to get 


\section{Thome=making in the Wuildernesg 445}

my guide, And desired the Hostess to inquire of her guest whether any of them would go with mee.

There was some difficulty about securing a guide, Madam Knight objecting to paying the price that was asked. She writes: ". . . I told her no, I would not be accessary to such extortion."

"'Then John shan't go,' sais shee. 'No, indeed, shan't hee.' And held forth at that rate a long time, that I began to fear I was got among the Quaking tribe, beleeving not a Limbertong'd sister among them could out do Madm. Hostes.

"Upon this, to my no small surprise, son John arrose, and gravely demanded what I would give him to go with me? 'Give you,' sais I, 'are you John?' 'Yes,' says he, 'for want of a Better'; And behold! this John look't as old as my Host, and perhaps had been a man in the last Century. 'Well, Mr. John,' sais I, 'make your demands.' 'Why, half a pss. of eight and a dram,' sais John. I agreed, and gave him a Dram (now) in hand to bind the bargain.

"My hostess catechis'd John for going so cheep, saying his poor wife would break her heart. . . ." 


\section{Dioneer SDothers of Elmerica}

All differences were smoothed out, however, and Madam was soon started on her journey. "When we had Ridd about an how'r," she continues, "wee come into a thick swamp, wch. by Reason of a great fogg, very much startled mee, it being now very Dark. But nothing dismay'd John: Hee had encountered a thousand and a thousand such Swamps, having a Universall Knowledge in the woods; and readily Answered all my inquiries wch. were not a few.

"In about an how'r or something more, after we left the Swamp, we come to Billinges, where I was to Lodg. My Guide dismounted and very Complasantly help't me down and shewd the door, signing to $\mathrm{me} \mathrm{w}^{\text {th }}$ his hand to Go in: $\mathrm{w}^{\text {ch }}$ I Gladly did-But had not gone many steps into the Room, ere I was Interogated by a young Lady I understood afterwards was the Eldest daughter of the family, with these, or words to this purpose, (viz.) 'Law, for mee-what in the world brings You here at this time a night?I never see a woman on the Rode so Dreadfull late, in all the days of my versall life. Who are You? Where are You going? I'me scar'd out of my witts' - with much more of the same Kind. I stood aghast, Prepareing to reply, 


\section{Thome=making in the valilderness 447}

when in comes my Guide-to him Madam turn'd Roreing out: 'Lawfull heart John, is it You? -how de do! Where in the world are you going with this woman? Who is she?' . . .

"I told her shee treated me very Rudely, and I did not think it my duty to answer her unmannerly Questions. But to get ridd of them, I told her I come there to have the post's company with me to-morrow on my Journey, \&c. Miss star'd awhile, drew a chair, bid me sitt, And then run up stairs and putts on two or three Rings, (or else I had not seen them before,) and returning, sett herself just before me, showing the way to Reding, that I might see her Ornaments, perhaps to gain the more respect.

"Tuesday, October $y^{\mathrm{e}}$ third, about 8 in the morning, I with the Post proceeded forward without observing any thing remarkable: And about two, afternoon, Arrived at the Post's second stage, where the western Post mett him and exchanged Letters. Here, having called for something to eat, $\mathrm{y}^{\mathrm{e}}$ woman bro't in a Twisted thing like a cable, but something whiter: and laying it on the bord, tugg'd for life to bring it into a capacity to spread: $\mathbf{w}^{\mathbf{c h}}$ 


\section{Dioneer Mothers of Emerica}

having $w^{\text {th }}$ great pains accomplished, shee serv'd in a dish of Pork and Cabage, I suppose the remains of Dinner. The sause was of a deep Purple, $w^{\text {ch }}$ I tho't was boil'd in her dye Kettle: the bread was Indian, and every thing on the Table service Agreeable to these. I, being hungry, gott a little down: but my stomach was soon cloy'd.

“. . . the Post told mee we had neer I4 miles to Ride to the next Stage, (where we were to Lodg.) I askt him of the rest of the Rode, forseeing wee must travail in the night. Hee told mee there was a bad River we were to Ride thro', $\mathrm{w}^{\text {ch }}$ was so very firce a hors could sometimes hardly stem it: But it was but narrow, and wee should soon be over. I cannot express The concern of mind this relation sett me in: no thoughts but those of the dang'ros River could entertain my Imagination, and they were as formidable as varios, still Tormenting me with blachest Ideas of my Approching fate - Sometimes seing my self drowning, otherwhiles drowned, and at the best like a holy Sister Just come out of a Spiritual Bath in dripping Garments.

"Now was the Glorious Luminary, $\mathrm{w}^{\text {th }}$ his 


\section{Thome=making in the ratilderness 449}

swift Coursers arrived at his Stage, leaving poor $\mathrm{me}^{\mathrm{th}}$ the rest of this part of the lower world in darkness, with which wee were soon Surrounded. The only Glimering we now had was from the spangled Skies, Whose Imperfect Reflections rendered every Object formidable. Each lifeless Trunk, with its shatter'd Limbs, appear'd an Armed Enymie; and every little stump like a Ravenous devourer. Nor could I so much as discern my Guide, when at any distance, which added to the terror.

"Thus, absolutely lost in Thought, and dying with the very thoughts of drowning, I come up $\mathrm{w}^{\text {th }}$ the post, who I did not see till even with his Hors: he told mee he stopt for mee; and wee Rode on Very deliberatly a few paces, when we entred a Thickett of Trees and Shrubbs, and I perceived by the Hors's going, we were on the descent of a Hill, $\mathrm{w}^{\mathrm{hr}}$ as wee come neerer the bottom, 'twas totaly dark $\mathrm{w}^{\text {th }}$ the Trees that surrounded it. But I knew by the Going of the Hors wee had entred the water, $\mathrm{w}^{\text {ch }}$ my Guide told mee was the hazzardos River he had told me off; and hee, Riding up close to my Side, Bid me not fear-we should be over Imediatly. I must either Venture my fate of drowning, 


\section{Dioncer Snotbers of Elmerica}

or be left like $\mathrm{y}^{\mathrm{e}}$ Children in the wood. So, as the Post bid me, I gave Reins to my Nagg: and sitting as Stedy as Just before in the Cannoo, in a few minutes got safe to the other side, which hee told mee was the Narragansett country. . . ." But even after safely crossing the hazardous ford and reaching the inn on the Narragansett side, Madam Knight's troubles were not at an end, for she writes: ". . . I could get no sleep, because of the Clamor of some of the Town tope-ers in next Room, Who were entered into strong debate. . . . I set my Candle on a Chest by the bed side, and setting up, fell to my old way of composing my Resentments, in the following manner:

I ask thy Aid, O Potent Rum!

To Charm these wrangling Topers Dum.

Thou hast their Giddy Brains possest-

The man confounded $\mathrm{w}^{\text {th }}$. the Beast-

And I, poor I, can get no rest.

Intoxicate them with thy fumes:

$\mathrm{O}$ still their Tongues till morning comes!

And I know not but my wishes took effect; for the dispute soon ended $\mathrm{w}^{\text {th }}$ 'tother Dram.' and so Good night!

"Wedensday, Octob. 4th. About four in 


\section{Thome=making in the valloerness 45 I}

the morning, we set out for Kingston . . . the post encourag'd mee, by saying wee should be well accommodated anon at $\mathrm{mr}$. Devills, a few miles further. But I questioned whether we ought to go to the Devil to be helpt out of affliction. However, like the rest of Deluded souls that post to $\mathrm{y}^{\mathrm{e}}$ Infernal denn, Wee made all posible speed to this Devil's Habitation: where alliting, in full assurance of good accommodation, wee were going in. But meeting his two daughters, as I suposed twins, they so neerly resembled each other, both in features and habit, and look't as old as the Divel himselfe, and quite as Ugly. . . .

"About seven that Evening, we came to New London Ferry: here, by reason of a very high wind, we mett with great difficulty in getting over. . . . between nine and ten at night waited on the Rev ${ }^{d}$ Mr. Gurdon Saltonstall, minister of the town, who kindly Invited me to Stay that night at his house, where I was very handsomely and plentifully treated and Lodg'd; . . .

"Friday, Octo 6th. I got up very early, in Order to hire somebody to go with mee to New Haven, being in Great perplexity at the 


\section{Dioncer Motbers of Fmerica}

thoughts of proceeding alone; which my hospitable entertainer observing, himselfe went, and soon return'd $w^{\text {th }}$ a young Gentleman of the town, who he could confide in to Go with mee . . about two a clock, afternoon we arrived at New Haven, where I was received with all Posible Respects and civility. Here I discharged $\mathrm{Mr}$. Wheeler with a reward to his satisfaction, and took some time to rest after so long and toilsome a Journey: And Inform'd myselfe of the manners and customs of the place, and at the same time employed myselfe in the affair I went there upon."

Madam Knight spent several weeks in New Haven and then continued her journey to New York, enjoying herself greatly the while, observing the "manners and customs of the place," commenting upon them in her journal, and comparing them with "ours in Boston." She considered the people of the Connecticut colony too independent in many ways and too strict in others and she was quite shocked at their complacency in regard to divorce, of which she writes: "These uncomely Standaways, are too much in vogue among the English in this indulgent colony, as their 


\section{Thome=making in the ratloerness 453}

records plentifully prove and that on very trivial matters."

Madam Knight measured everything by her Boston standard. She considered the people of New Haven awkward and bucolic and writes in her journal that "Their want of improvements, renders them almost ridiculous."

Her opinion was evidently much better of the people in New York, for she wrote that "They are 'sociable' and 'courteous," and farther on, that "they are not so strict in keeping the Sabbath as in Boston," and also that "they treat with good liquor liberally," neither of which facts seems to have disturbed her in the least.

Madam Knight greatly enjoyed her fortnight's sojourn in the Dutch colony, especially the fine sleighing and "the houses of entertainment at a place called the Bowery," and she writes that she left the "pleasant city with no little regret."

Her return journey to Boston was even more difficult than the one to New York, for it was made in midwinter and the intense cold, the snow, and the ice added much to her hardships. But she arrived safe in Boston on March 3d, 


\section{Dioncer Mothers of Almerica}

I705, and was welcomed by her "tender mother" and her "dear and only child," and her many friends, who, she says, came "flocking in."

Shortly after her return from New York, Madam Knight opened a school in her residence on Moon Street, which attracted considerable attention, as a female school-teacher was a rarity. A number of her pupils became distinguished in after years, the two most noted being Benjamin Franklin and Samuel Mather.

Madam Knight's latter years were spent in New London and at Norwich, where she had moved, following the marriage of her daughter, and where she owned several farms. Her residence, however, was in Norwich, as was the church which she attended, and there is a record that she presented it with a silver communion cup, in remembrance of which the town voted her permission "to sit in the pew where she used to sit."

The final picture that we have of her is at her "Livingston Farm" on the Norwich road in New London, where she kept "entertainment for travellers." And we can feel assured that the weary traveller found with Madam Knight 


\section{home=making in the trailderness 455}

far more hospitable entertainment than that which she described in her journal.

Madam Knight died September 25, I727 at her "Livingston Farm," leaving behind her a reputation for unusual energy and ability. She was held in high repute by her many friends and neighbours both throughout her life and afterwards. But she, like her father before her, once ran afoul of the Puritan laws, being charged with "selling strong drinks to the Indians."

\section{Mary Ball Washington}

Following the overthrow of the royal house of Stuart, there emigrated to Virginia a number of cavaliers, among them William Ball, son of an attorney of Lincoln's Inn, who, in I650, settled in Lancaster County. His descendants held good positions in the social life of the Colony and their names appear in Bishop Meade's list of vestrymen, as founders and patrons of the Indian schools, and fourteen different times in the House of Burgesses. They married with the first families who settled the counties of Westmoreland, Northumberland, Stafford, and Lancaster. 


\section{Dioneer SiDothers of America}

Their coat of arms, like that of their English forebears, was a lion rampant holding a ball, and their motto was, "Cœlumque tueri."

An armorial document belonging to Colonel William Ball bears this coat of arms and has the following note written on the back:

"The Coat of Arms of Colonel William Ball, who came from England about the year I650, leaving two sons-William, of Millenbeck (the paternal seat) and Joseph of Epping Forestand one daughter, Hannah, who married Daniel Fox. . . . Joseph's male issue is extinct."

The youngest daughter of the Joseph Ball mentioned in this document was Mary-who became the mother of George Washington. She was born at Epping Forest, Lancaster, Virginia, in 1708.

Of the "Widow Johnson" - Mary Ball Washington's mother-very little is known. It has been claimed, but never proven, that she was descended from the Montagues of England, but she is supposed to have been Joseph Ball's housekeeper and to have married him after the death of his first wife. Even her maiden name is unknown and the only remaining record that we have of her is a clause of her husband's 


\section{Dbome=making in the Valloernesg 457}

will, written June 25, I 7 I I, wherein he mentions "Eliza Johnson, daughter of my beloved wife." A few weeks later, Joseph Ball died and within a year, or before Mary was five years old, her mother married Captain Richard Hewes, a vestryman of St. Stephen's parish, Northumberland, and she and her three children, John and Elizabeth Johnson, and Mary Ball, removed to that parish to live.

Captain Hewes died in I7I3, and upon the thrice-widowed mother of Mary fell the duty of raising and educating the children. The estates left her by Joseph Ball and Richard Hewes, while not making her wealthy, placed her in comfortable circumstances, and even though we lack authentic information as to her life for the ensuing eight years, we can easily assume that Mary Ball's childhood life and education were similar to those of other Virginia girls of her time and station. When Mary was thirteen years old, her mother died, and the following extracts from her will show her thoughtful affection for her youngest daughter:

"Imprimis, I give and devise unto my Daughter, Mary Ball, one young likely negro woman to be purchased for her out of my Estate 


\section{$45^{8}$ Dioneer SiDotbers of America}

by my Executors and to be delivered unto her, the said Mary Ball, at the age of Eighteen years, - . two gold rings, the one being a large hoop and the other a stoned ring . . . one young mare and her increase, which said mare, I formerly gave her by word of mouth . . . sufficient furniture for the bed her father Joseph Ball left her, vist: One suit of good curtains and fallens, one Rugg, one Quilt, one pair Blankets . . . two Diaper Table clothes, marked M. B. with inck, and one Dozen of Diaper napkins, two towels, six plates, two pewter dishes, two basins, one large iron pott, one Frying pan, one old trunk . . . one good young Paceing horse together with a good silk plush side saddle to be purchased by my Executors out of my Estate. . . . All the rest of my wearing apparel [she had given her daughter Elizabeth 'one suit of white and black callico'] . . . and I do hereby appoint her [to] be under. Tutiledge and government of Capt. George Eskridge during her minority."

Mary Ball's half-brother, John Johnson, who had been named as joint executor of his mother's will, died very soon after her, his will and hers being recorded on the same day, and 


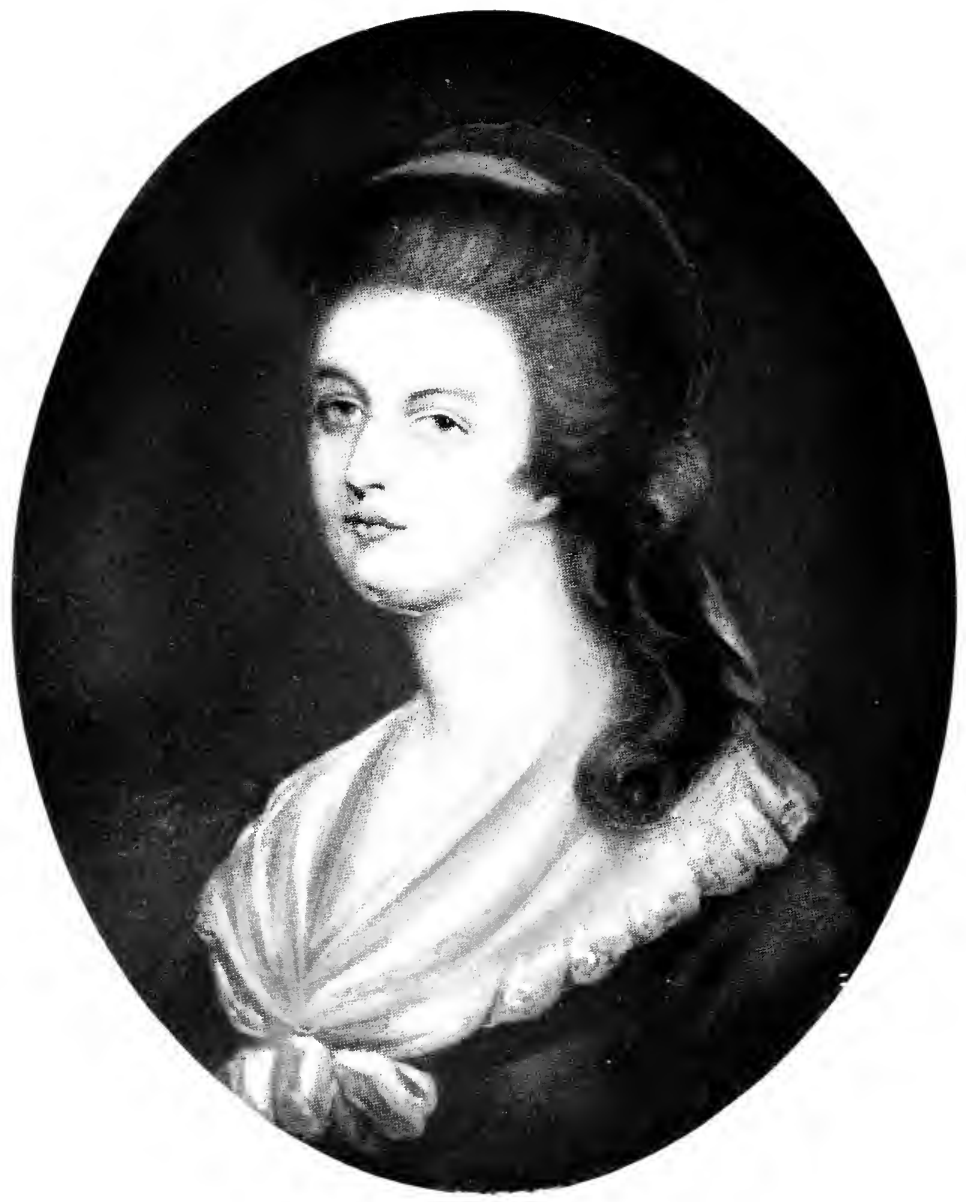

Mary Ball Washington.

From the picture painted by Middleton and restored by Edward Bird, R.A. 



\section{Thome=making in the Wuiloernesg $46 \mathrm{I}$}

his first bequest shows the affection that he bore for his half-sister.

"Imprimis. I give and bequeath unto my sister, Mary Ball, all my land in Stafford which my father in law Richard Hewes gave me, to the said Mary Ball and heirs lawfully to be begotten of her body forever."

Another bequest, six years later, gives added proof of the friendly relations that existed between Mary Ball and the various members of her family; this was from her brother-in-law, Samuel Bonum, who married her half-sister, Elizabeth Johnson. Mr. Bonum's will was probated in Westmoreland, Feb. 22, I726, and contains an item bequeathing "to my sister-in-law, Mary Ball, my young dapple gray riding horse."

These various legacies not only go to show the friendly feelings which existed between Mary Ball and her kindred, but also indicate that, while not wealthy, she was at least well equipped for a maid of her time and would not be without a dower on her wedding-day.

From the death of her mother, there is not much of authentic record of her life, until her marriage to Augustine Washington, in I730, with the exception of the reference made in the 


\section{Dioneer SMothers of Elmerica}

wills of her half-brother and her brother-in-law. Up until I 864-5, there seemed to be no definite information regarding those early years of Mary Ball's life, but near the close of the Civil War, a Union soldier discovered, by accident, a bundle of old letters in an abandoned house in Yorktown, which brought delight to the hearts of the biographers, to whom they seemed to furnish the missing information as to the girlhood of Mary Ball. The first letter was from "WmsBurg, Ye 7th of Oct., I722," and read:

"DeAR Sukey-Madam Ball of Lancaster and her sweet Molly have gone Hom. Mama thinks Molly the Comliest Maiden She Knows. She is about 16 yrs. old, is taller than $\mathrm{Me}$, is verry Sensable, Modest and Loving. Her Hair is like unto Flax. Her Eyes are the colour of Yours, and her Chekes are like May blossoms. I wish You could see her."

Another letter, supposed to have been written by Mary herself to her brother in England, was also found:

"We have not had a schoolmaster in our neighborhood until now in five years. We have 


\section{Thome=making in the tuilderness 463}

now a young minister living with us who was educated at Oxford, took orders and came over as assistant to Rev. Kemp at Glouster. That parish is too poor to keep both, and he teaches school for his board. He teaches Sister Susie and me, and Madam Carter's boy and two girls. I am learning pretty fast. Mama and Susie and all send love to you and Mary. this is from your loving sister,

\section{"Mary Ball."}

The fragment of another letter was found, signed "Lizzie Burwell," written to "Nelly Car-," and dated "May ye I5th, I728." The letter is badly torn, only part of a sentence being decipherable: “. . . understand Molly Ball is going Home with her Brother, a lawyer who lives in England. Her Mother is dead three months ago."

For forty years these letters were accepted as being authentic, biographers used them as a basis in picturing the girlhood of Washington's mother, and they were reverently laid beneath the corner-stone of the Mary Washington monument. But, within the last ten years, the Rev. G. W. Beale has discovered in the archives of 


\section{Pioneer Sibotbers of America}

Northumberland County, Va., the will of Mary Hewes, widow of Captain Richard Hewes, who was also the widow of Joseph Ball-the father of Mary Ball Washington.

The discovery of this will destroyed whatever value the "Mary Ball" letters may have had as far as Mary Ball Washington was concerned, for its contents clearly proved that Mary Ball's girlhood was not spent in Lancaster, and that she was not untaught until she was sixteen, but on the contrary had every opportunity for education; that she did not visit Williamsburg with her mother when she was sixteen, and at the time of the date of the Williamsburg letter, her mother had been dead a number of years. With the foundation thus destroyed, the carefully reared structure of romance that had been builded upon it fell to the ground. But while the researches and discoveries of the Rev. G. W. Beale spoiled some very pretty stories and traditions, they gave us what was of more value-some authentic information regarding the early life of Mary Ball.

Seven years before Mrs. Hewes's death, her daughter, Elizabeth Johnson, Mary Ball's halfsister, married Samuel Bonum and moved to 


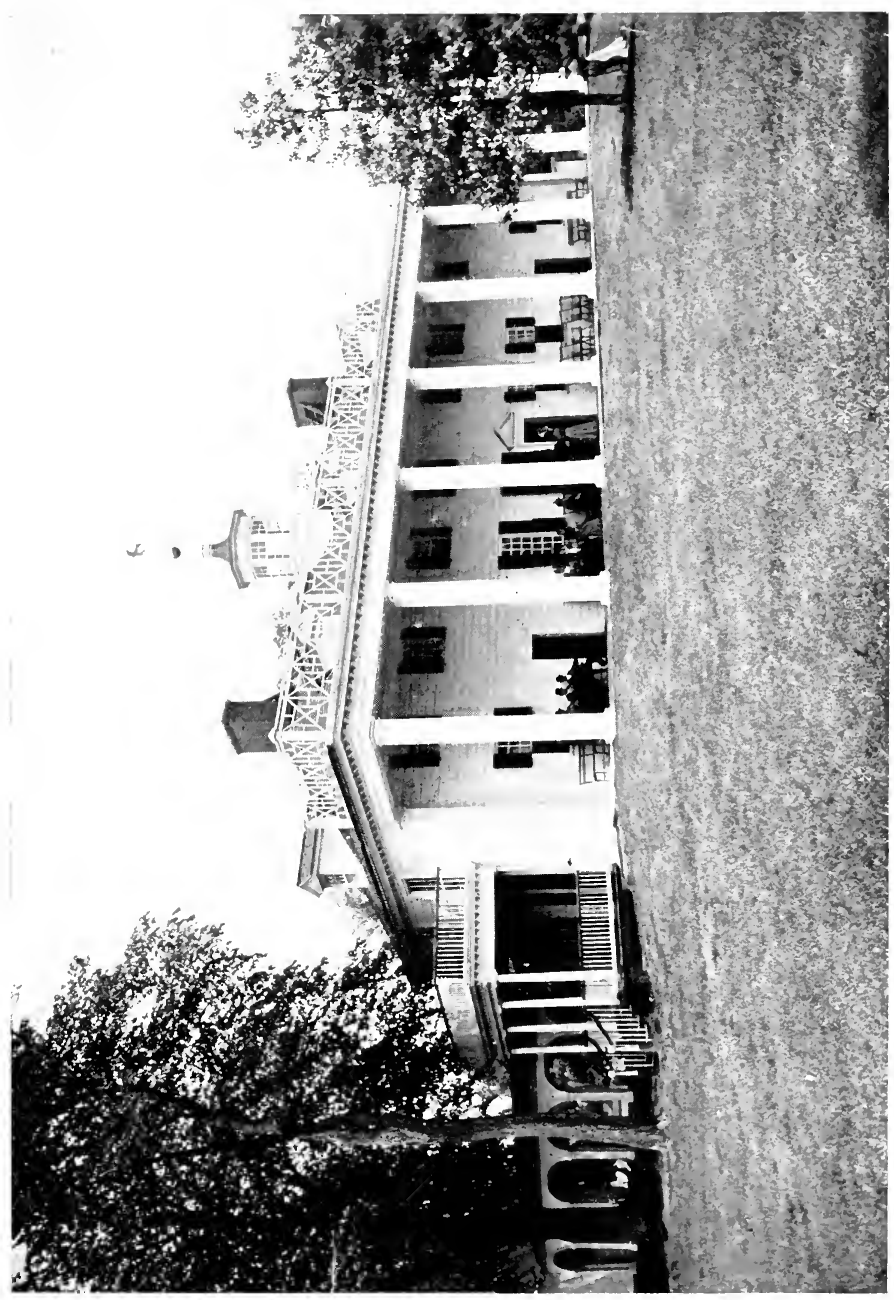

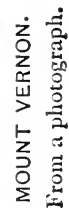





\section{Thome=inaking in the rolliloerness 467}

her husband's home in Westmoreland, and it was probably to this home that thirteen-yearold Mary Ball was taken upon her mother's death. The Bonum home was a mile and a half from Sandy Point, the residence of Major George Eskridge, under whose "tutiledge and government" Mary Ball had been placed by the terms of her mother's will. And so there can be but little doubt that Mary Ball was reared and educated as well as her station and the times would permit. Major Eskridge was a wealthy and prominent lawyer and a man of education and refinement. He had seven children, one daughter, Sally, being but a year older than Mary. That she always had a great affection for her guardian and for her half-sister and her husband, there can be but little doubt. Her first-born son was named George Eskridge, another son was named Samuel Bonum, and her only daughter was named Elizabeth, for her half-sister.

In the early spring of 1730 , Mary Ball married Augustine Washington, a widower, and went to reside on her husband's plantation of Wakefield. Mrs. Roger A. Pryor, in her The Mother of Washington, tells an interesting story re- 


\section{Dioncer SWotbers of America}

garding the young bride's first inspection of her new home:

"It appears that she was arrested in this voyage of discovery by a small but rare treasure of books. Standing before the diamond-paned 'secretary,' she examined one volume after another. Finally, turning over the leaves of one, she read: 'On Moderation and Anger,' 'On Self-Denial,' 'On ye Vanity and Vexation which ariseth from Worldly Hope and Expectation.' These seemed to her words of wisdom by which one might be guided. The title-page announced 'Sir Matthew Hale's Contemplations,' the fly-leaf revealed the name of the owner, the first wife, 'Jane Washington.' Finding the ink-horn, she wrote firmly beneath, 'And Mary Washington."' It is said that this book was her constant companion and that she read and reread it to her children and that it was greatly reverenced by George Washington. The old volume is still among the treasures at Mount Vernon.

On Feb. 22, I732, at the Wakefield plantation, was born Mary Ball Washington's first child; it was a boy and she named him George Eskridge Washington, in honour of Major George 


\section{Thome=making in the Tchilderness 469}

Eskridge, the guardian and friend of her girlhood. When George was about seven years of age, his father moved from the old Wakefield home to Overwharton parish, County of Stafford, on the Rappahannock, opposite Fredericksburg, where he built a new home which he called "Pine Grove."

Augustine Washington died on April I2, I743, aged forty-nine, and his widow, then aged thirty-five, was left with the care of his seven children, two sons by his first wife, Lawrence and Augustine, and Mary Ball's own children, George, Samuel, John Augustine, Charles, and Betty, who later married Fielding Lewis; the other daughter, little Mildred, had died in infancy.

George Washington was eleven years old at the time of his father's death, and he "had probably had fully four years of as careful and thorough education as any boy in any age could have had." But after this date his training and guidance were entirely in the hands of his mother and it was to the impress that she and her training made upon his character that Washington referred, when he paid his famous tribute: "All that I am I owe to my mother." That this gallant tribute 


\section{Dioncer Smothers of Almerica}

was not undeserved few will question. For the underlying principles which guided George Washington throughout his entire life were those that had always been so dear to the heart of his mother and that she had striven so earnestly to instil in the heart of her son.

Mary Washington was not yet thirty-six years of age at the time of her husband's death. She was left with a family of seven children to rear and a large estate to manage. Her step-son, Lawrence, married Anne Fairfax shortly after his father's death, and went to live upon his inherited estate of "Hunting Creek."

Of Mary Washington's responsibilities and the way that she met them, Mrs. Pryor says: "She early proved herself to be a strong, selfreliant woman, with executive ability and a supreme power of awing and governing others. Her life was given to her children and to the care of a thriving plantation, to sowing and planting and reaping; to the rearing of fine, blooded cattle. Her children had a plain, abundant, comfortable home, and led healthy out-of-door lives. She made Truth and Honour her handmaidens, and in their defence ruled her house with austerity, that 'austerity in woman 


\section{Thome=making in the ruldoerness $47 \mathrm{I}$}

so often the accompaniment of a rare power of loving, causing love to be piety, tenderness, religion, devotion strong as death.'

"Surrounding her children with all the comforts of a well-governed household, she loved them, taught them, persuaded them. If all failed, if Sir Matthew Hale was in vain, and headlong youth yielded not when the right was at issue, she did not disdain to command another influence, pliant, pungent, prompt, and most convincing, - a bundle of keen rods gathered daily from the friendly peach tree."

George Washington Parke Custis often visited Mrs. Washington in his childhood and knew well a number of her neighbours and friends. In speaking of this period of her early widowhood, he says:

"Bred in those domestic and independent habits which graced the Virginia matrons in the old days of Virginia, this lady, by the death of her husband, became involved in the cares of a young family, at a period when those cares seem more especially to claim the aid and control of the stronger sex. It was left for this eminent woman, by method most rare, by an education and discipline the most peculiar and imposing, 


\section{Dioneer Sibothers of America}

to form in the youth-time of her son those great and essential qualities which gave lustre to the glories of his after-life. If the school savoured more of the Spartan than the Persian character, it was a fitter school to form a hero, destined to be the ornament of the age in which he flourished, and a standard of excellence for ages yet to come."

Mary Washington's first care was given to maintaining the inheritance of her childrenthe land that had been left in her care, with the arrangement that each child should receive his share upon arriving at maturity; the next duty was that of educating them. In carrying out this, she not only took advantage of whatever facilities the section offered, but supplemented this by her own training in the things that no books could teach. It was some of the qualities thus instilled in the mind of Washington that Lecky refers to, "punctual, methodical, and exact in the highest degree, managing the minute details so essential to the efficiency of an army." It was the training in these minor virtues as well as the greater ones, and in the inherited qualities among which was "a rare form of courage which can endure long-continued 


\section{Thome=making in the Tulilderness 473}

suspense, bear the weight of great responsibility, and encounter, without shrinking, risk of misrepresentation and unpopularity" that was the foundation of George Washington's greatness; such qualities needed only opportunity to produce their result.

In I747, George's half-brother, Lawrence, obtained for him a midshipman's warrant which thoroughly fitted in with his boyish desire to go to sea, but after conferring by letter with her half-brother in England, his mother at the last minute persuaded him not to accept it, and less than a year later we find him entered as a surveyor under Lord Fairfax. Hereafter, the mother had to depend for her influence and guidance of her son upon the reverence that he held for her early teachings.

Not much is known of Mary Washington's life from the time of the French and Indian War to the Revolution, but these years could not but have been filled with interest and care. Her son Samuel married five times: Jane Champe, Mildred Thornton, Lucy Chapman, Anne Steptoe, and the widow Perrin. In addition to this, he was very unfortunate in money matters, and having a large number of children, found 


\section{Dioneer SIDothers of Elmerica}

it "hard to get along," his brothers continually helping him. His children were frequent visitors at Mount Vernon; the names of two of them, Steptoe Washington and Harriett Washington, being often on the General's expense book. And we find him saying, "She was not brung up right. She has no disposition, and takes no care of her clothes, which are dabbed about in every corner and the best are always in use," a state of things which his own careful upbringing had taught him to abhor. Again, he writes to his brother John Augustine, "In God's name how has Samuel managed to get himself so enormously in debt?" If these things troubled an elder brother, they were much more apt to have been a source of care to a mother.

John Augustine married Hannah Bushrod, and went to reside in Westmoreland. Charles, the youngest, married another Mildred Thornton and made his home in Charlestown, Jefferson County. Betty Washington had succeeded her aunt Catherine (Washington) Lewis and had become the second wife of Fielding Lewis.

The widow Washington was now left alone 


\section{Thome=making in the Vulloerness 475}

at "Pine Grove," and very empty indeed must have seemed the old house, but there was no word of complaint from the mother who had striven so earnestly and so well to play the part of both mother and father to her children, and she went on with her own busy life, "minding her own affairs and utterly free from idle curiosity."

Of Madam Washington's personality during her latter middle life, many people have written many varying descriptions, some authentic, some picturesque, and some ridiculous, but from the testimony that has come down to us, from those who knew her best, her neighbours, relatives, and friends, we learn that she was possessed of a manner dignified to austerity, but that always compelled respect and obedience; that her voice was firm yet sweet and musical, and that "she was always cheerful in spirit"; also that "in her person she was of the middle size, and finely formed; her features pleasing yet strongly marked." The picture that we have of her at this period is best given by one of her family, who says: "She was conspicuous for an awe-inspiring manner, so characteristic in the Father of our Country. All who knew her 


\section{Pioncer Mothers of America}

will remember the dignified matron as she appeared when the presiding genius of her well-ordered home, commanding and being obeyed."

Mrs. Pryor has summed up this portion of Mary Washington's life, and in fact her whole life in the following words: "It was her pleasure to live simply-at a time of almost riotous profusion. It was her pleasure to busy her own hands with the housewifely work of her own household,-knitting, sewing, sorting fleeces for 'Virginia cloth,' preserving fruits, distilling herbs for the sick,- 'making drudgery divine' by sharing the task she laid upon others, thereby earning her many gifts to the poor. In an age of abundant leisure she was industrious; in an age of dissipation of time and money she was self-denying, diligent, and frugal; in an age when speech was free and profanity 'genteel' she preserved her temperate speech; was unpolluted by the faintest taint of coarseness or irreverence. When the church no longer concerned itself with the care of men's souls, she kept her own serene, in her simple faith that prayer would prevail in the end, performing every outward religious duty as conscien- 


\section{Thome=making in the Wuilderness 477}

tiously as if the priests and bishops showed, as well as taught, the way."

But dark days were coming to Mary Washington, as they were coming to thousands of other mothers throughout the Colonies. On her quiet plantation on the Rappahannock, she had heard but little of the excitement that was stirring the people; the "Stamp Act," the "Tea Tax," the "Boston Tea Party," had little personal meaning to her. All the ties of tradition and kinship, of church and sense of duty, drew her to the "Mother Country," and she considered it an "overwhelming disaster that her four sons, to say nothing of her neighbours and kinsfolk, should resist the will of their King." After war had been declared and she heard that her son George was to lead the Continental Army, she expressed disapproval vigorously: "Oh," she said, to "Grandma Knox," who endeavoured to console her, "is there to be more fighting, more bloodshed? Surely it will all end in the halter." Indeed her feelings at the time were so strong that when her son, then General Washington, went to try and induce her, for her own safety, to move into Fredericksburg, he was very much in doubt as to how she 


\section{Dioneer SDothers of America}

would receive him and stopped at a little inn nearby to investigate before proceeding farther. To the servants, it was so unusual a thing for a member of the family to "put up at the tavern" that none dared tell Mrs. Washington, but she, seeing such an air of mystery in their faces, demanded an explanation. On hearing it she exclaimed, "Tell George to come home instantly -instantly!" And George came, and received his mother's blessing, if not her approval. It was not until the war closed and he was a victorious commander of the army that George Washington again crossed his mother's threshold.

Madam Washington was left very much unprotected through this period, but this in no wise disturbed her and she continued on her duties with the calmness, industry, and method that were her wont. When her daughter, Betty Lewis, in the mansion at "Kenmore," near Fredericksburg, tried to persuade her to come to her "to be taken care of," she declined, saying: "My wants are few in this life, and I feel perfectly competent to take care of myself." She did, however, make her home very near to "Kenmore," from which she drove every day to her plantation across the river to 


\section{Thome=making in the railderness}

supervise its administration and to bring back seeds and cuttings for her town garden and a jug of water from her favourite spring.

Fredericksburg being in the line of direct communication between Washington's headquarters and Williamsburg, Madam Washington was enabled to keep in fairly constant communication with her son. It is said that she would not tolerate any expressions of complaint during this trying period and she is quoted as saying: "The mothers and wives of brave men must be brave women."

"Hers was a familiar form in Fredericksburg during the Revolution," writes Mr. Custis, "and its people showed her every respect as she walked the streets leaning on her cane. Devout and worshipful, she appeared every Sabbath at church at the appointed hour; and while the armies under her son were struggling, the knitting needles were busily plied, and from her home went forth her modest contributions of supplies for him and his soldiers."

In spite of her calmness and serenity, Madam Washington aged rapidly during the years of the Revolution, and this necessitated a change in a number of her habits, among which was 


\section{Dioneer Sisothers of America}

her method of worship. Of this Mr. Custis says: "She was always pious, but in her latter days her devotions were performed in private. She was of the habit of repairing every day to a secluded spot, formed by rocks and trees, near her dwelling, where abstracted from the world and worldly things, she communed with her Creator, in humiliation and prayer."

This "secluded spot" was known as "Oratory Rock" and was situated on the "Kenmore" grounds, which belonged to her son-in-law, Colonel Lewis. It looked out over the Rappahannock at that time, but since then the river has changed its channel. It was Mary Washington's wish that she might be buried near this spot.

Madam Washington's life was rapidly nearing its end. The war was ended and again she clasped her first-born in her arms and saw him honoured and admired of all men.

There followed for the mother of the great commander several very peaceful and pleasant years. Her son George, while frequently called away from his Mount Vernon home to aid in the affairs of the colonies, still found time to pay her frequent visits, as did her other children, with the exception of Samuel, who had died. 


\section{Thome=making in the rchildoerness $48 \mathrm{r}$}

And also she was surrounded by relatives and friends who accorded her full measure of love and respect. That her relations with her children at this time were the pleasantest and that they continued so until her death, there is every evidence.

On April the I4th, I789, Washington, then at Mount Vernon, received official notice that he had been unanimously chosen as the first President of the United States, and on that same evening he set out on horseback, accompanied by one body servant, for Fredericksburg, to bid farewell to his mother. A portion of the conversation between the mother and son at this famous interview has come down to us. "So soon," the General is quoted as saying, "as the public business, which must necessarily be encountered in arranging a new government can be disposed of, I shall hasten to Virginia" -but here his mother interposed. "You will see me no more," she said. "Age and disease warn me that I shall not be long in this world; I trust in God and am somewhat prepared for a better. But go; fulfil the high destinies which Heaven appears to assign you; go, and may Heaven's and your mother's blessing be vol. $I-3 I$ 


\section{Dioneer Motbers of America}

with you always." This was the last meeting of Washington and his mother.

Before her death, she made two visits, one to the home of her son Charles, and the other to the widow of Samuel. She died August 25, I 789 , attended by her daughter, Betty Lewis, and her good friend Dr. Charles Mortimer, and on August 27th was laid by reverent hands in the spot chosen by herself.

There is a tradition that George Washington desired to mark his mother's last resting place with a monument, but was deterred from this by the fact that the country claimed this privilege. Twice were bills presented in Congress for such an appropriation, but both were lost. In I830, the women of Fredericksburg formed an organisation for this purpose, when they received a letter from Silas E. Burrows of New York, requesting permission to donate the monument. This offer was accepted and the corner-stone laid, in the presence of Andrew Jackson; but before the monument was placed upon its foundation the donor, contractor, and stone mason all died, and the unfinished structure stood as the contractor left it until it was replaced by the present monument, 


\section{Thome=making in the Tulloerness 483}

which was the "first ever erected by women, in honour of a woman."

In 1857, Captain George Washington Ball (grandson of Colonel Burgess Ball and Frances Washington) endeavoured to raise money to complete the "Burrows" monument and to erect a college for women near it. He worked for eleven years on this project but was unsuccessful. It was not until the early nineties that anything further was attempted. Then a number of women organised the Mary Washington Memorial Association, striking off gold and silver medallions with her image upon them. The number was limited to six hundred and the medallions were to be handed down from mother to daughter, thus forming a perpetual Guard of Honour over the grave of Mary Washington. The Princess Eulalia of Spain, and Maria Pilar Colon, a descendant of Christopher Columbus, were admitted to this order, and permitted to wear its insignia. The cause of this revival in the interest in the mother of General Washington was an advertisement which appeared in the Washington newspapers, stating that the "Grave of Mary, the Mother of General Washington," was to be "sold at Public Auction, 


\section{IDioneer SMothers of Imerica}

the same to be offered at Public Outcry." The following summer, a number of the descendants of the friends and neighbours of Mary Washington met at White Sulphur Springs, Virginia, where a ball was given to aid the efforts of the widow of Chief Justice Waite to purchase the park and erect a monument over Mary Washington's grave.

The corner-stone of the monument erected with this fund was laid Oct. 20, I893, and on May Io, I894, it was dedicated by President Cleveland. The town of Fredericksburg was beautifully decorated and the ceremonies very impressive.

The Chief Justice of the United States, the Justices of the Supreme Court, the members of the Cabinet, companies of infantry, cavalry, and artillery, formed an imposing procession, which was headed by a number of beautiful young women, dressed entirely in black with black hats and black sable plumes, and mounted on horseback.

It was the late Senator Daniel of Virginia who said upon this occasion:

"But for the light that streamed from the deeds of him she bore, we would doubtless have 


\section{Thome=making in the ruildernesg 485}

never heard the name of Mary Washington, and the grass that grew upon this grave had not been disturbed by curious footsteps or reverential hands. But it does not follow that she shines only in the reflection of her offspring's fame. Her virtues were not created, they were discovered by the marvellous career of her illustrious son. . . There were ten thousand Mary Washingtons among the mothers of the Revolution, and honouring her we honour the motherhood of heroic days and heroic men."

\section{NOTES TO CHAPTER VIII}

$\therefore$ The Waywayanda Patent was granted by twelve Indian sachems to John Bridges \& Co., and confirmed by Queen Anne, March 5, I 703. The twelve patentees were John Bridges, LL.D., Hendryck Teneyck, Derrick Vandeburgh, John Chotwell, Christopher Denne, Lancaster Syms, Daniel Herran, Philip Rockeby, John Meredith, Benjamin Ashe, Peter Mathews, and Christian Christianse.

" This tavern, known as "Greycourt," was a noted building for close to a century and a half and was only destroyed within the last decade.

3 The old chief who had adopted "Betty" Draper had recently lost a daughter, and he and his wife formed a great affection for the young white woman and treated her as a daughter. She in time came to have a genuine affection for her adopted parents, though the hopes of escape and of returning to her husband and family were never out of her mind. She tried to escape but was recaptured and sentenced to death. Her foster-father concealed her for weeks while he was working to secure her pardon, which he finally effected. Six years passed, but in 1761 , after the treaty of peace had been made, John Draper went to the Indian country and finally found his wife and ransomed her, though he had to pay heavily. They returned to the Kanawha Valley, where they raised a family of seven children. 






